Prepared for the Lower Columbia River Estuary Partnership

and the Bonneville Power Administration

under the Non-Federal Work for Others Program

with the U.S. Department of Energy

Contract DE-AC05-76RL01830

\title{
Lower Columbia River and Estuary Ecosystem Restoration Program Reference Site Study: 2011 Restoration Analysis
}

\section{FINAL REPORT}

AB Borde

VI Cullinan

HL Diefenderfer

RM Thom

RM Kaufmann
SA Zimmerman

J Sagar

KE Buenau

C Corbett

May 2012

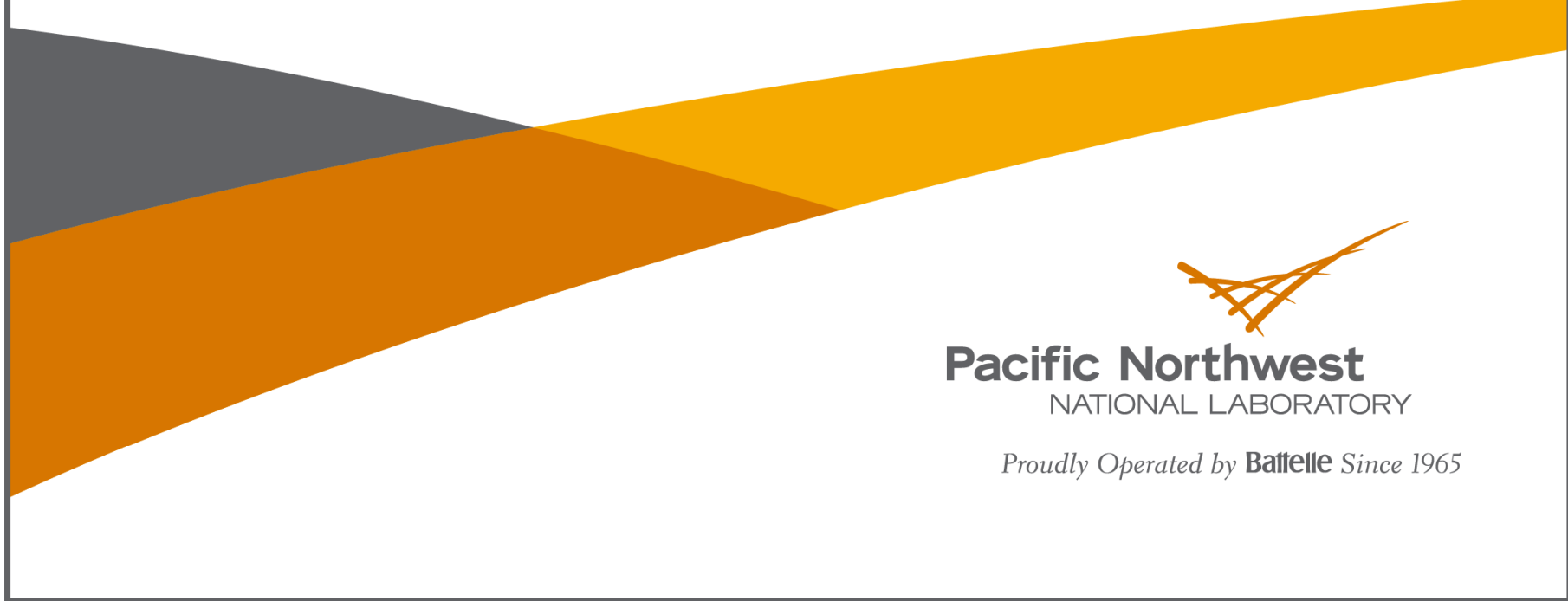




\title{
DISCLAIMER
}

This report was prepared as an account of work sponsored by an agency of the United States Government. Neither the United States Government nor any agency thereof, nor Battelle Memorial Institute, nor any of their employees, makes any warranty, express or implied, or assumes any legal liability or responsibility for the accuracy, completeness, or usefulness of any information, apparatus, product, or process disclosed, or represents that its use would not infringe privately owned rights. Reference herein to any specific commercial product, process, or service by trade name, trademark, manufacturer, or otherwise does not necessarily constitute or imply its endorsement, recommendation, or favoring by the United States Government or any agency thereof, or Battelle Memorial Institute. The views and opinions of authors expressed herein do not necessarily state or reflect those of the United States Government or any agency thereof.

\author{
PACIFIC NORTHWEST NATIONAL LABORATORY \\ operated by \\ BATTELLE \\ for the \\ UNITED STATES DEPARTMENT OF ENERGY \\ under Contract DE-AC05-76RL01830
}

Printed in the United States of America
Available to DOE and DOE contractors from the Office of Scientific and Technical Information,
P.O. Box 62, Oak Ridge, TN 37831-0062;
ph: (865) 576-8401
fax: $(865)$ 576-5728
email: reports@adonis.osti.gov

\footnotetext{
Available to the public from the National Technical Information Service, U.S. Department of Commerce, 5285 Port Royal Rd., Springfield, VA 22161 ph: (800) 553-6847 fax: (703) 605-6900 email: orders@ntis.fedworld.gov online ordering: http://www.ntis.gov/ordering.htm
}

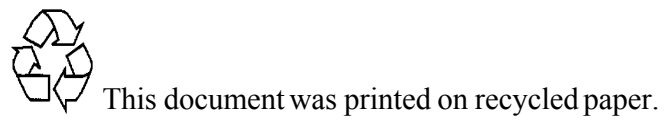




\title{
Lower Columbia River and Estuary Ecosystem Restoration Program Reference Site Study: 2011 Restoration Analysis Final Report
}

\author{
AB Borde \\ SA Zimmerman \\ VI Cullinan \\ J Sagar $^{1}$ \\ HL Diefenderfer \\ KE Buenau \\ RM Thom \\ C Corbett ${ }^{1}$ \\ RM Kaufmann
}

May 2012

Prepared for

Prepared for the Lower Columbia River Estuary Partnership and the Bonneville Power Administration under the Non-Federal Work for Others Program with the U.S. Department of Energy

Contract DE-AC05-76RL01830

Pacific Northwest National Laboratory

Richland, Washington 99352

\footnotetext{
${ }^{1}$ Lower Columbia Estuary Partnership, Portland, Oregon.
} 



\begin{abstract}
The research presented in this report is part of the regional habitat restoration program in the lower Columbia River and estuary (LCRE). As part of this program, we have established a suite of reference sites to help meet the goal of understanding and restoring wetland habitat. The data collected at these reference sites from 2005 through the present were analyzed in this study to meet two primary objectives: 1) to inform restoration planning and design by quantifying the ecological and hydrological conditions necessary for development of wetland plant communities and tidal channel networks and 2) to evaluate the effectiveness of wetland restoration actions in the LCRE by comparing restoration and reference site monitoring data. In this report, we present the results of the analysis of 51 reference wetland sites, focusing on the elevation, sediment, and inundation ranges required by native tidal wetland vegetation. We describe critical factors influencing existing wetland patterns in the LCRE, including the vegetation assemblages present, the elevation ranges at which they occur, and the inundation dynamics that result in their current distribution. Finally, we present how these data can be used to evaluate restoration action effectiveness.
\end{abstract}





\section{Executive Summary}

The Reference Site (RS) study is part of the research, monitoring, and evaluation (RME) effort developed by the Action Agencies (Bonneville Power Administration, U.S. Army Corps of Engineers, Portland District, and U.S. Bureau of Reclamation) in response to Federal Columbia River Power System Biological Opinions. Although the RS study was initiated in 2007, data have been collected at relatively undisturbed reference wetland sites in the lower Columbia River and estuary (LCRE) ${ }^{1}$ by the Pacific Northwest National Laboratory (PNNL) and collaborators since 2005. These data on habitat structural metrics were previously summarized to provide baseline characterization of 51 wetlands throughout the estuarine and tidal freshwater portions of the 235-km LCRE; however, further analysis of these data has been limited. Therefore, in 2011, we conducted additional analyses of existing field data previously collected for the Columbia Estuary Ecosystem Restoration Program-including data collected by PNNL and others - to help inform the multi-agency restoration planning and ecosystem management work under way in the LCRE.

The goal of the 2011 RS study reported herein was to help inform the restoration planning and management effort in the LCRE by exploring two guiding questions:

1. What are the ranges of selected environmental factors controlling the establishment and distribution of wetlands in the LCRE, and what vegetation communities are associated with these ranges in different parts of the LCRE?

2. Can structural data from multiple reference sites be used to evaluate restoration action effectiveness in the LCRE and if so, what metrics are most useful to this evaluation?

The general approach of this study was to further analyze existing data from a suite of 51 reference wetlands in conjunction with analysis of available comparable data from 10 restoration projects initiated within the last decade.

Our analysis first develops the basis for the distribution of vegetation characteristic of the region using available ecological and hydrological data. We then use discriminant function analysis of the vegetation data from the least disturbed sites to provide verification for the observed hydro-vegetation zonation. We conclude the analysis of vegetation patterns by providing the elevational ranges of selected plant species and communities for the different hydro-vegetation zones of the LCRE. Finally, we compare reference sites to restoration sites within each of these zones; evaluating several metrics including accretion rates, elevation, temperature, vegetation, and channel morphology.

We summarize the conclusions from the Reference Site study according to two main topics: 1) gradients in the vegetation assemblages relative to hydrodynamics and other factors and 2) the relative similarity of restored sites to reference sites.

\footnotetext{
${ }^{1}$ The term "lower Columbia River and Estuary" (LCRE) and the term "estuary" are used interchangeably in this document to refer to the tidal extent of the lower Columbia River; from the mouth to the Bonneville Lock and Dam at $\mathrm{rkm} 235$.
} 


\section{Hydro-Vegetation Zones}

Shallow-water vegetation assemblages show distinct differences along the gradient between the mouth of the river and the upstream end of the estuary at Bonneville Lock and Dam. There are three zones based on species richness; the central region ( $\mathrm{rkm} 50$ to $\mathrm{rkm} \mathrm{150)}$ has the greatest number of species, and the upper and lower ends of the estuary have lower numbers of species. These three species richness zones can be characterized hydrodynamically as tidal-dominated, mixed tidal and riverdominated, and river-dominated, moving from the mouth of the Columbia River to Bonneville Dam.

We hypothesize that fewer vegetation species are physiologically adapted to the extreme inundation in the upper end of the estuary, and, likewise, few are adapted to the tidal variability and salinity in the lower estuary. The fact that the mixed zone contains the greatest number of species suggests that the natural ecological disturbance regime may be lower there, and there may be a larger species pool adapted for these conditions in this zone. This intermediate disturbance hypothesis has been used in many ecosystems to describe the conditions that result in higher species diversity.

Further examination of the hydrologic gradient revealed that the estuary can be divided further into five zones, driven primarily by salinity intrusion at the lower end and stronger fluvial flooding influence at the upper end. The breaks for these zones occur at approximately rkm 40, 104, 136, and 181. These breaks are preliminary and should be refined with additional data in areas of sparse sites and with other hydrologic analyses currently under way.

The five hydro-vegetation zones developed from this analysis provide a means of determining the ranges of controlling factors (e.g., elevation, hydrology, accretion rates) at reference sites within each zone. These ranges can then be used to inform restoration planning for sites within each zone. Further, the zones provide a means of comparing restoration sites to relevant reference sites that have similar factors controlling their habitat structure, as discussed below.

The elevation range for the major habitat types (e.g., emergent, shrub, or forested wetland) within a zone is small (i.e., $<2 \mathrm{~m}$ ), which strongly suggests that elevation and hydrodynamics must be carefully considered in 1) the design of wetland restoration sites, 2) the analysis of differences between sites, and 3 ) the trajectories and rate of development of restored sites.

With the results from this analysis, the elevation and possibly the growing season inundation (as measured by the sum exceedance value (SEV)) can be used to predict species presence at sites within the same hydro-vegetation zone. For example, the invasive species reed canary-grass (Phalaris arundinacea), covered the widest range in elevation of any species. In general, these data on elevations of vegetation species should help in planning restoration actions to maximize native species and minimize the invasion of reed canary-grass into new sites.

\section{Relative Similarity of Restored to Reference Sites}

In this section, we summarize the findings from the restoration and reference site comparison then also provide a judgment of the usefulness of each metric as a restoration performance measure. 
Sediment Accretion. Most restored sites showed initiation of the process of sedimentation. Accretion indicates that the sites are behaving as sinks of sediment and probably organic matter-two processes indicative of wetland systems. Accretion rates tended to be greater in restored sites as compared to the least-disturbed reference sites.

Usefulness of metric: Sediment accretion is required to build wetland elevations and is easily and cost-effectively measured in the field. This metric provided a valuable means of comparing restoration to reference conditions in the analysis.

Elevation. Elevations of previously diked restored sites were lower than reference sites. Again, this suggests that accretion is needed to restore the sites to the historical vegetation assemblage. The excavated site was more similar to reference elevations than other hydrologically reconnected sites.

Usefulness of metric: This metric can be difficult and expensive to measure in the field but is invaluable to determine the likelihood of a site establishing the target hydrologic patterns and vegetation community. The simple comparison of the average, minimum, and maximum elevations proved a simple means of comparing the site elevations.

Inundation. Natural hydrological connection and dynamics were restored at the two sites where sufficient hydrological data were available. The hydrologic patterns are likely driving the development and function of the restored sites.

Usefulness of metric: Hydrologic data are essential to determining whether a site has the necessary processes for wetland development. The lack of data from restoration sites resulted in few comparisons, however, we feel the analysis of SEV could be a useful means of evaluating the effect of hydrologic patterns on vegetation particularly when the elevation or hydrology are expected to be different from reference conditions (e.g., tide gate installation).

Water Temperature. Water temperature in restored and reference sites typically first exceeded the Washington State Department of Ecology threshold value for juvenile salmon in late spring. In a few cases, the temperature exceedance occurred in reference sites later than at the restoration sites, likely due to proximity to the main channel and local effects of shade. At the few restoration sites where we had data from multiple sensors within a site, patterns were evident relative to the distance from the outlet or the presence or absence of perennial stream inputs. We did not have pre-restoration data on temperatures, but based on data from a few sites collected before reconnection, we believe that water temperature after reconnection probably remained below the threshold longer as compared to pre-reconnection at the sites we studied.

Usefulness of metric: Temperature is a useful metric for evaluating conditions within wetland areas, particularly habitat function for aquatic species. The date of first exceedance of a temperature criterion is a viable method for determining differences between sites and also for evaluating the condition of the habitat provided at a site. 
Vegetation Composition. The bivariate analysis showed that the composition of selected species at some restoration sites was tending toward the composition at the reference sites. The probability of occurrence showed that the species composition of the highest-cover species at the restoration sites was not the same as that of the reference sites, although some similar species were present and increasing over time. Invasive species, particularly reed canary-grass, were a problem at all restoration sites.

Usefulness of metric: The bivariate analysis is a useful way to compare the cover and composition of desired species. The analysis is most useful when reed canary-grass is not highly dominant in the reference sites that are used to compare to the restoration site. This species was not included in the bivariate analysis because it is not one that is "desirable" in these systems. However, the species is very dominant and affects the cover of many other species that occur within the same elevation range at both the restoration and some reference sites.

The probability of occurrence analysis was a useful way to look at the most common species at the sites and compare the cover and composition over time and between the restoration and reference sites.

Vegetation Similarity. The vegetation assemblages at nearly all restoration sites had very low similarity to reference site vegetation. Hogan Ranch and the sites planted with shrubs and trees showed the highest similarity. Sites that were historically forested swamps and had been converted to pasture land showed the lowest similarities to their reference sites. Where data were available for multiple years, restoration sites showed a decreasing similarity from the earliest sampling to the most recent. This suggests that the vegetation is changing rapidly from the initial conditions. Based on previous studies, we suspect that similarity between restored sites and their reference sites will increase measurably over time but not for at least another 5-10 years.

This analysis showed there to also be variability between the reference sites, which could be caused by factors such as recent and historical disturbances (e.g., dredged material placement). This variability illustrates the need to evaluate reference site differences and possibly further stratify the reference sites for comparison to restoration sites.

The reference site similarity was also variable between years. Previous PNNL research found similar results and suggests using the long-term average similarity in reference sites to establish a target similarity between the restoration site and reference site. Because most sites were measured in only one year and not always the same year for all reference sites in the zone, temporal variability must be included in determining the target similarity for the restoration sites.

Usefulness of metric: The similarity index is a very useful way to make broad comparisons based on the vegetation cover and composition between sites and over time.

Channel Morphometry. The channel length plotted against channel cross sectional area at the mouth was an effective means of comparing the restoration and reference sites. Of the four restoration sites compared, one appeared to have too small of a channel outlet, one was unnecessarily large, and two were within the same range or at the expected ratio found at the reference sites. We suspect that the restored channels will trend toward reference site dimensions if hydrological connection is unconstrained. 
Channel width at the outlet plotted against the channel depth at the outlet confirmed that two of the channels had similar dimensions to the reference channels and two were considerably deeper relative to the width as compared to the reference channels. Interestingly, these two sites were also the ones with the most similar length-to-area ratios, so perhaps the deeper channels are necessary to adequately drain the area at these sites.

Usefulness of metric: Analysis of channel morphometry can be used to determine the similarity of restoration channels to reference channels when other metrics of hydraulic geometry are not available (e.g., catchment area and total channel length). We found that the primary channel length versus cross-sectional area at the mouth may be a useful measure. However, because channels in reference systems are often complex this analysis should be compared to reference sites using the complete channel network to determine if the relationship is valid. The width-to-depth ratio of channel outlet is useful to evaluate whether a restoration channel is similar to reference channels; however, it does not reflect whether these dimensions are appropriate relative to the size of the site.

Overall, our findings provide new information on factors structuring shallow-water vegetated habitats along the entire estuary gradient. The relationships between location, hydrology, and elevation provide valuable potential predictors useful in restoration planning and to evaluate the rates and trajectories of restored sites.

\section{Recommendations}

The following recommendations resulting from this study are specific to the methods for future analysis. These are not recommendations for restoration actions. Specific recommendations for data management include the following:

- Standardize data organization and summarizing across data collection efforts in the estuary.

- Develop a continuous dataset for all time-series data.

- Use the U.S. Department of Agriculture plant database for vegetation identification (or identify which field guide is used).

- Record vegetation data using scientific name, rather than common name

- Measure elevation data in North American Vertical Datum of 1988 via local benchmark, then convert to the Columbia River Datum where appropriate (i.e., above rkm 35 in the mainstem; not in tributary sites).

- Compile summarized data into one database or spreadsheet for analysis.

The following recommendations would improve the ability to make comparisons between reference sites and restoration sites in the future:

- The differences between reference sites because of recent and historical disturbances need to be evaluated and possibly stratified further prior to comparison to restoration sites.

- Interannual variability needs to be better quantified at reference sites within the estuary. 
- Channels in reference systems are often complex. The analysis conducted here on primary channel length should be compared to one using the complete channel network to determine if the relationship between primary channel length and area at channel outlet is valid.

- Additional monitoring data are needed at restoration sites to better understand if sites are developing toward fully functioning and resilient ecosystems, to inform the adaptive management process, and ultimately improve restoration action effectiveness in the future. 


\section{Acknowledgments}

Foremost, we wish to thank the Lower Columbia River Estuary Partnership for recognizing the importance of this research and facilitating the work since 2007. Specifically, we thank Scott McEwen, who was instrumental in initiating the project and who provided many helpful ideas in the formative stages. We also appreciate the efforts of Jason Karnezis, whose previous work gathering potential reference site information was the starting point for site selection. Evan Haas also provided support during the field collection years. We are grateful to the sponsoring agency, Bonneville Power Association, for providing the funds to carry out the project. We thank the property owners-Columbia Land Trust, The Nature Conservancy, and the Garvin family-for allowing access and providing information about their beautiful properties. The following agencies were also instrumental in providing access to and information about several reference sites throughout the estuary: Scappoose Bay Watershed Council, Oregon State Parks, Oregon Department of Fish and Wildlife, National Park Service, and the U.S. Fish and Wildlife Service. We appreciate the willingness of restoration practitioners to share their monitoring data. Finally, we could not have completed this project without the people who helped conduct the field work, at times putting in very long hours and enduring arduous conditions. We are very grateful for the hard work and great attitudes of Amanda Bryson, Jimmie Cotton, Dana Field, Julia Ledbetter, Lori Lilly, Keith Marco, Dave Nichols, Micah Russell, Ian Sinks, Kathryn Sobocinski, and Allan Whiting. 



\section{Acronyms and Abbreviations}

\begin{tabular}{|c|c|}
\hline 7DADmax & seven-day running average of the daily maximum \\
\hline $\mathrm{BiOp}$ & Biological Opinion \\
\hline BPA & Bonneville Power Administration \\
\hline $\mathrm{CE}$ & Cumulative Ecosystem Response to Restoration Program \\
\hline CEERP & Columbia Estuary Ecosystem Restoration Program \\
\hline CLT & Columbia Land Trust \\
\hline CRD & Columbia River Datum \\
\hline CREST & Columbia River Estuary Study Taskforce \\
\hline EM & emergent marsh \\
\hline FCRPS & Federal Columbia River Power System \\
\hline GIS & geographic information system \\
\hline GPS & Global Positioning System \\
\hline $\mathrm{km}$ & kilometer(s) \\
\hline LCRE & Lower Columbia River and Estuary \\
\hline LCEP & Lower Columbia Estuary Partnership \\
\hline $\mathrm{m}$ & meter(s) \\
\hline MLLW & mean lower low water \\
\hline NAVD88 & North American Vertical Datum of 1988 \\
\hline nMDS & nonmetric multidimensional scaling \\
\hline NOAA & National Oceanic and Atmospheric Administration \\
\hline PNNL & Pacific Northwest National Laboratory \\
\hline rkm & river kilometer \\
\hline RME & research, monitoring, and evaluation \\
\hline $\mathrm{RS}$ & Reference Site \\
\hline RTK & real-time kinematic \\
\hline SAV & submerged aquatic vegetation \\
\hline SEV & sum exceedance value \\
\hline TOC & total organic carbon \\
\hline USACE & U.S. Army Corps of Engineers \\
\hline USFWS & U.S. Fish and Wildlife Service \\
\hline USGS & U.S. Geological Survey \\
\hline WADOE & Washington State Department of Ecology \\
\hline WSE & water surface elevation \\
\hline
\end{tabular}





\section{Contents}

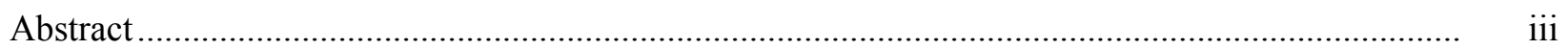

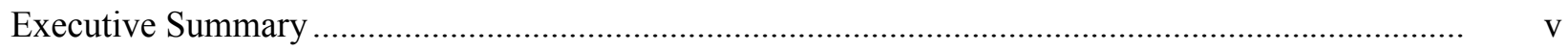

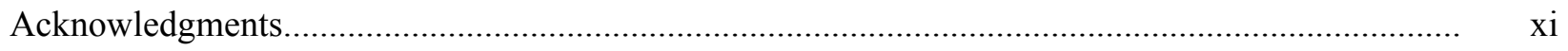

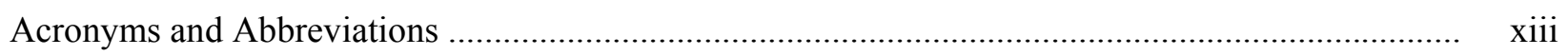

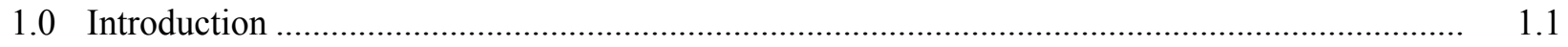

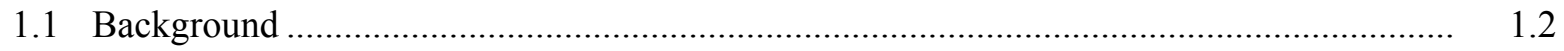

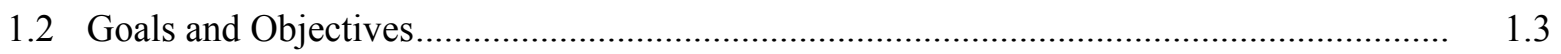

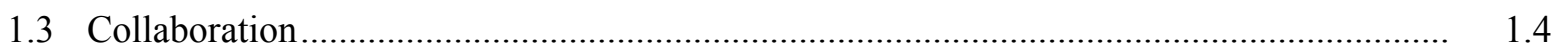

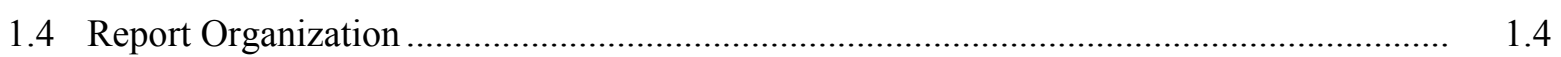

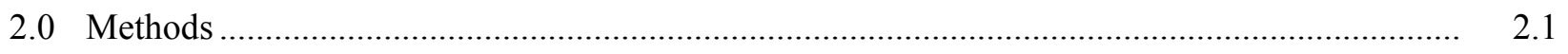

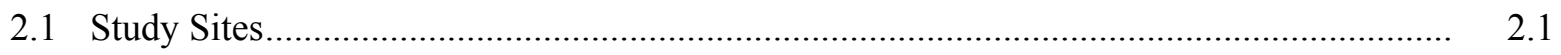

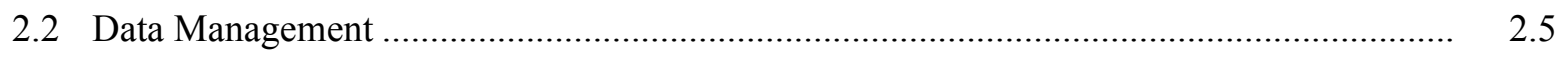

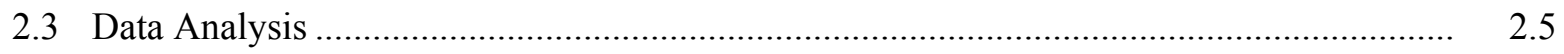

2.3.1 Vegetation Distribution Patterns .................................................................. 2.5

2.3.2 Reference and Restoration Site Comparison ..................................................... 2.8

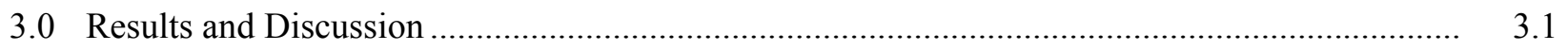

3.1 Vegetation Zonation Data ................................................................................ 3.1

3.1.1 Vegetation Distribution Patterns along the Estuarine Gradient ........................... 3.1

3.1.2 Vegetation Elevation Ranges ......................................................................... 3.9

3.2 Reference and Restoration Site Comparison........................................................... 3.10

3.2.1 Sediment Accretion Rate ................................................................................. 3.11

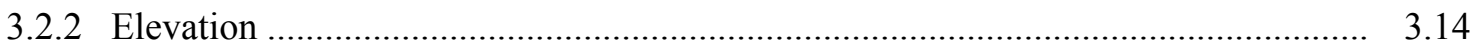

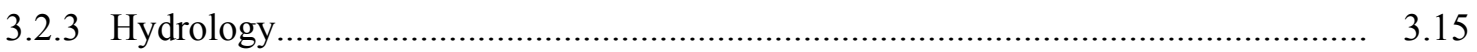

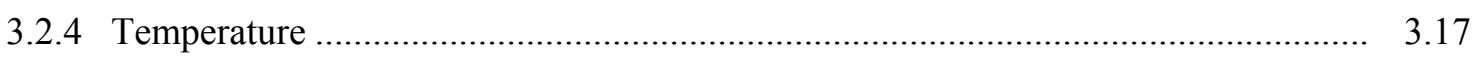

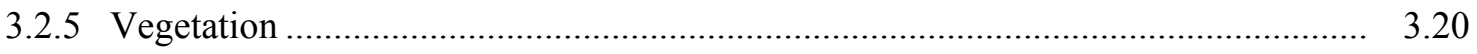

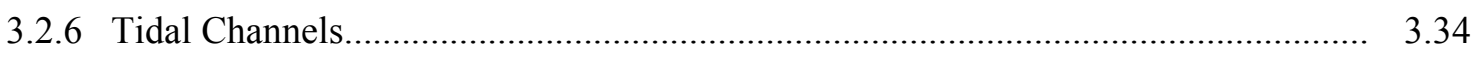

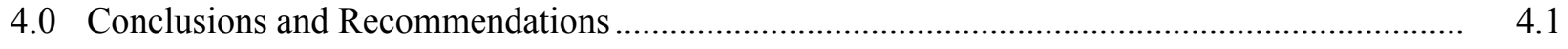

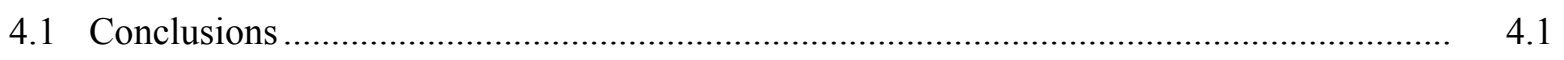

4.1.1 Vegetation Assemblage Gradients ................................................................ 4.1

4.1.2 Relative Similarity of Restored to Reference Sites ............................................. 4.2

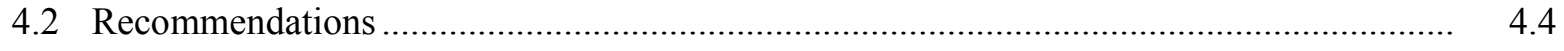

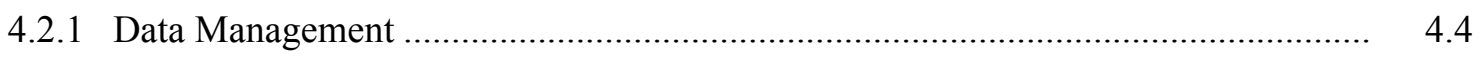

4.2.2 Reference to Restoration Site Comparisons …............................................... 4.5

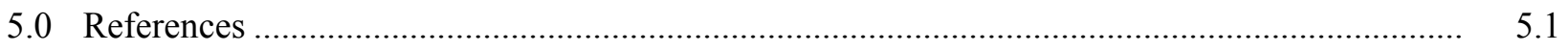

Appendix A - Temperature Graphs .................................................................................. A.1

Appendix B - LCR Reference and Restoration Site Study Plant List ......................................... B. 1

Appendix C - Site Maps ....................................................................................................... C.1 


\section{Figures}

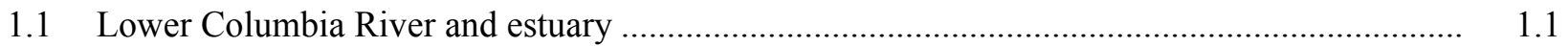

2.1 Reference and restoration sites in the lower Columbia River and estuary ............................... 2.1

2.2 Comparison of the mean, median, and the 25th and 75th percentile ..................................... 2.7

3.1 Maximum number and average number of species observed at the reference sites versus the distance of the sites from the river mouth ........................................................................... 3.2

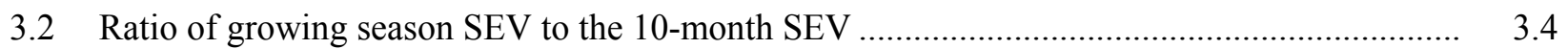

3.3 Cluster analysis of least-disturbed marshes denoted by river kilometer and color .................... 3.5

3.4 The $\log _{10}$ growing season SEV versus river kilometer ..................................................... 3.6

3.5 The $\log _{10}$ growing year SEV versus river kilometer, with proposed zones delineated ............... 3.7

3.6 Scatter plot of the discriminant scores for five emergent marsh groups ................................... 3.7

3.7 Estimated boundaries of the hydro-vegetation zones showing location of reference and restoration sites evaluated in the study

3.8 Annual accretion rates for all reference sites measured in the estuary as part of this study ....... 3.11

3.9 Annual accretion and/or erosion rates for the years following the restoration action at four tributary restoration sites compared to reference sites in hydro-vegetation zone 1

3.10 Annual accretion and/or erosion rates for all restoration sites in Vera Slough and Crims Island compared to reference sites in the respective hydro-vegetation zones

3.11 Average elevation for the vegetation sample area at restoration sites Vera Slough, Kandoll Farm, and Crims Island compared to the average elevation of the reference site sample areas in each hydro-vegetation zone

3.12 Sum exceedance value as calculated for the growing season and for a full year at Kandoll Farm compared to the tributary marsh reference sites in hydro-vegetation zone 1; Kandoll Farm compared to forested wetland reference sites in hydro-vegetation zone 1; and Crims Island compared to the marsh reference sites in hydro-vegetation zone 2 .

3.13 Bivariate analysis of average percentage cover of Carex spp. relative to Typha spp. at restoration sites in hydro-vegetation zone 1 compared to reference sites in the mainstem and tributaries

3.14 Bivariate analysis of average percent cover of Eleocharis palustris relative to Sagittaria latifolia at restoration sites compared to reference sites in hydro-vegetation zone 2 and hydro-vegetation zone 4

3.15 The probability of occurrence of plant species at restoration sites Fort Clatsop and Kandoll Farm compared to the probability of occurrence of the dominant species in the leastdisturbed marsh tributary reference sites in hydro-vegetation zone 1

3.16 The probability of occurrence of plant species at restoration sites Vera Slough compared to the probability of occurrence of the dominant species in the least-disturbed marsh mainstem reference sites in hydro-vegetation zone 1

3.17 The probability of occurrence of plant species at restoration site Crims Island compared to the probability of occurrence of the dominant species in the least-disturbed marsh reference sites in hydro-vegetation zone 2 . 
3.18 The probability of occurrence of plant species at restoration site Hogan Ranch compared to the probability of occurrence of the dominant species in the least-disturbed marsh reference sites in hydro-vegetation zone 4.

3.19 Dendrogram and an nMDS plot of the similarity between the restoration sites Fort Clatsop and Kandoll Farm relative to tributary emergent marsh reference sites in hydro-vegetation zone 1 using complete linkage and Relative Sørensen's similarity measurements.

3.20 Dendrogram and an nMDS plot of the similarity between the restoration sites Kandoll Farm and Fort Clatsop and forested swamp reference sites using complete linkage and relative Sørensen's similarity measurement.

3.21 Dendrogram and an nMDS plot of the similarity between the restoration site Vera Slough relative to selected reference sites using complete linkage and relative Sørensen's similarity ..

3.22 Dendrogram and an nMDS plot of the similarity between the restoration site Crims Island relative to mainstem emergent marsh reference sites in hydro-vegetation zone 2 using complete linkage and relative Sørensen's similarity

3.23 Dendrogram and an nMDS plot of the similarity between the restoration site Hogan Ranch relative to selected reference sites using complete linkage and relative Sørensen's similarity .. $\quad 3.30$

3.24 Relationship between channel length and channel cross sectional area at the outlet for restoration and associated reference sites.

3.25 Relationship between channel width and channel depth at the outlet for restoration and associated reference sites 


\section{Tables}

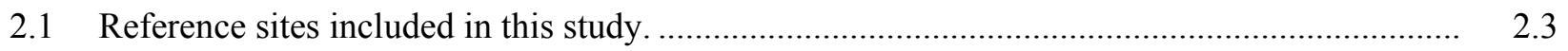

2.2 Restoration sites included in this study...................................................................... 2.4

2.3 Metrics for which data were available from the restoration sites included in this study. .......... 2.5

2.4 Classification and number of identified wetland taxa observed within quadrats from marsh sites only.

3.1 Relationships between water level dynamics, water properties, and vegetation species richness and cover in the lower Columbia River based on our findings.

3.2 Probability of the most common vegetation species occurring at each marsh reference site .....

3.3 Marsh elevation ranges and the most common species in each of the hydro-vegetation zones

3.4 Forested and shrub wetland elevation ranges in the two forested wetland vegetation zones......

3.5 Restoration sites and the reference sites within the hydro-vegetation zones.

3.6 Date of first WADOE 7-day average maximum temperature exceedance at Vera Slough and the associated marsh reference sites in hydro-vegetation zone 1.

3.7 Date of first WADOE 7-day average maximum temperature exceedance at Kandoll Farm and Fort Clatsop restoration sites and the associated marsh tributary reference sites in hydro-vegetation zone 1 .

3.8 Date of first WADOE 7-day average maximum temperature exceedance at Kandoll Farm and Fort Clatsop restoration sites and the associated forested reference sites in hydrovegetation zone 1

3.9 Date of first WADOE 7-day average maximum temperature exceedance at Tenasillahe and the associated reference sites

3.10 Date of first WADOE 7-day average maximum temperature exceedance at Hogan Ranch and the associated reference sites in hydro-vegetation zone 4.

3.11 Date of first WADOE 7-day average maximum temperature exceedance at Crims Island restoration site and the associated reference sites in hydro-vegetation zone 2.

3.12 Date of first WADOE 7-day average maximum temperature exceedance at Mirror Lake restoration site and the associated reference sites in hydro-vegetation zone 5.

3.13 Similarity of the herbaceous strata between the restoration sites Kandoll Farm and Fort Clatsop and tributary emergent marsh reference sites in hydro-vegetation zone 1

3.14 Similarity of the herbaceous strata between the restoration sites Kandoll Farm and Fort Clatsop and forested swamp reference sites in hydro-vegetation zone 1

3.15 Similarity of the herbaceous strata between the restoration site Vera Slough and mainstem emergent marsh reference sites in hydro-vegetation zone 1

3.16 Similarity of the herbaceous strata between the restoration site Crims Island and mainstem emergent marsh reference sites in hydro-vegetation zone 2

3.17 Similarity of the herbaceous strata between the restoration site Hogan Ranch and mainstem emergent marsh reference sites in hydro-vegetation zone 4 ....

3.18 Similarity of the shrub strata between the restoration site Mirror Lake and mainstem forested riparian reference sites between $\mathrm{rkm} 75$ and $\mathrm{rkm} 235$ 
3.19 Similarity of the tree strata between the restoration site Mirror Lake and mainstem forested riparian reference sites between $\mathrm{rkm} 75$ and rkm 235 .

3.20 Similarity of the shrub strata between the Sandy River Delta restoration site and mainstem forested riparian reference sites between $\mathrm{rkm} 75$ and $\mathrm{rkm} 235$

3.21 Similarity of the tree strata between the Sandy River Delta restoration site and mainstem forested riparian reference sites between $\mathrm{rkm} 75$ and $\mathrm{rkm} 235$ 



\subsection{Introduction}

The Reference Site (RS) study is part of the research, monitoring, and evaluation (RME) effort developed by the Action Agencies (Bonneville Power Administration [BPA], U.S. Army Corps of Engineers, Portland District [USACE], and U.S. Bureau of Reclamation) in response to Federal Columbia River Power System (FCRPS) Biological Opinions (BiOp) (NMFS 2000, 2004, 2008). A subsequent Supplemental BiOp (NMFS 2010) since the study began has not substantively altered elements of the BiOp directly relevant to the study. The RS study was conducted in the lower Columbia River and estuary $^{1}$ (LCRE; Figure 1.1) by the Pacific Northwest National Laboratory (PNNL) under contract with the Lower Columbia Estuary Partnership (LCEP), with funding provided by BPA through the Northwest Power and Conservation Council Columbia Basin Fish and Wildlife Program.

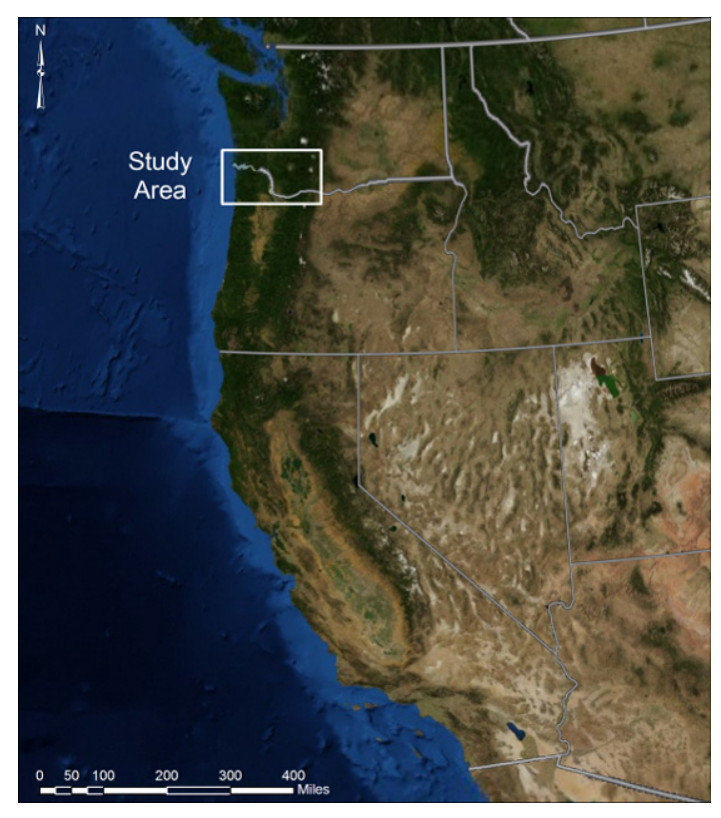

Figure 1.1. Lower Columbia River and estuary.

Although the RS study was initiated in 2007, data have been collected at relatively undisturbed ${ }^{2}$ reference wetland sites in the $\mathrm{LCRE}^{3}$ by PNNL and collaborators since 2005 under the RME effort (Johnson et al. 2008). These data on habitat structural metrics were previously summarized to provide baseline characterization of wetlands throughout the estuarine and tidal freshwater portions of the $235-\mathrm{km}$ LCRE (Borde et al. 2011); however, further analysis of these data has been limited. Therefore, in 2011, we conducted additional analyses of existing field data previously collected for the Columbia Estuary

\footnotetext{
${ }^{1}$ The term "lower Columbia River and estuary" (LCRE) and the term "estuary" are used interchangeably in this document to refer to the tidal extent of the lower Columbia River; from the mouth to the Bonneville Lock and Dam at $\mathrm{rkm} 235$.

2 "Undisturbed" in this context refers to the lack of direct physical disturbances, such as development, diking, recreational activities, or direct hydrological modification. There may have been historical modifications to a site, such as dredged material placement, or alterations to a site due to the changes in overall hydrologic and sedimentary processes in the Columbia River in the past 100 years.

Comprehensive descriptions of the LCRE study area are available in previous reports of this project (Borde et al. 2011) and other documents of the RME program (Johnson et al. 2008).
} 
Ecosystem Restoration Program (CEERP) - including data collected by PNNL and others - to help inform the multi-agency restoration planning and ecosystem management work under way in the LCRE.

\subsection{Background}

In the science of ecological restoration, a reference site is generally defined as a site with environmental conditions similar to those desired at the restoration site and as little disturbed by human activity as possible. As Downes et al. (2002. p. 122, Box 5.1) wrote, "These locations are often not chosen with a particular impact in mind, but to represent what a water body could be, or probably would be, in the absence of human disturbance." The RME plan recommended that a suite of reference sites be monitored as part of action effectiveness research on the LCRE to enable future restoration site progress to be assessed by comparison; several general methods for such analysis have been proposed for the LCRE (Johnson et al. 2008; Diefenderfer et al. 2011). Restoration under the CEERP has to date been focused on tidal freshwater and estuarine wetland habitats including marshes, shrub-dominated wetlands, and forested wetlands. Therefore, reference sites comparable to the restoration objectives for each of these vegetation communities are needed.

The rationale for restoration of these vegetated wetlands for listed salmon encompasses direct habitat access for fish as well as the production and export of macrodetritis, a substantial component of the estuarine food web (Bottom et al. 2005; ISAB 2011). The tidal channels intersecting vegetation in the floodplain also provide habitat for many fish and wildlife species, including juvenile salmon (Bottom et al. 2005), and contribute to overall biodiversity of the ecosystem (Tabor 1976). The structural habitat metrics sampled on the RS study, vegetation composition and species cover, provide an indication of emergent marsh production and the potential for organic matter (i.e., macrodetritus) export. Macrodetritis remains important to juvenile salmon foraging in main-stem LCRE habitats (Maier and Simenstad 2009), although its mass is thought to have decreased by some $82 \%$ relative to historical levels in the Columbia River (Sherwood et al. 1990; ISAB 2011) because of the well-documented loss of these types of vegetated wetlands.

The metrics analyzed in this study are outlined in the LCRE restoration monitoring protocols (Roegner et al. 2009; hereafter Protocols) as important for assessments of the structure, condition, and forcing factors of brackish and tidal freshwater wetland habitats. The parameters included in these analyses are vegetation composition and percentage cover, marsh elevation, water surface elevation, channel morphology, substrate characteristics, and accretion rates.

The hydrologic regime is of course a fundamental and determining characteristic of all wetlands (Mitch and Gosselink 2000), and the disruption of this regime by diking, water withdrawals, and dam operations is the driving factor in the loss of shallow-water habitats in the LCRE (Kukulka and Jay 2003a, 2003b). Elevation, hydrology, and substrate are the primary factors that control wetland vegetation composition and productivity (Gilman 1993), and sediment accretion is important for maintaining wetland elevation (Elliot 2004). Thus, baseline information on sediment accretion rates is important for predicting the evolution of a restoration site, particularly because sites being restored in the LCRE have often subsided significantly while diked (Diefenderfer et al. 2008; Borde et al. 2011).

Other parameters are indicators of habitat functions. For instance, the assessment of channel cross sections and channel networks provides information on the potential for fish access or opportunity (Simenstad and Cordell 2000) as well as the pathway for export of prey, organic matter, and nutrients. 
Information on channel morphology also supports development of the relationship between crosssectional dimensions and marsh size, which aids in understanding the channel dimensions characteristic of self-maintaining restored marshes and provides information for restoration project design (Diefenderfer et al. 2009).

Periodic analyses of data on indicators of structural and functional components of the LCRE ecosystem, such as those reported herein, are foundational to the adaptive management program described by Thom et al. (2011). In particular, such analyses contribute greatly to our understanding of expected rates of recovery of wetland ecosystems following hydrologic reconnection actions in this region. They also improve our ability to use principles of ecological succession in restoration design (Shuwen et al. 2001) and to predict the magnitude and characteristic environmental effects of future management actions.

\subsection{Goals and Objectives}

The goal of the 2011 RS study reported herein was to help inform the restoration planning and management effort in the LCRE by exploring two guiding questions:

1. What are the ranges of selected environmental factors controlling the establishment and distribution of wetlands in the LCRE, and what vegetation communities are associated with these ranges in different parts of the LCRE?

2. Can structural data from multiple reference sites be used to evaluate restoration action effectiveness in the LCRE, and if so, what metrics are most useful to this evaluation?

The general approach of this study was to further analyze existing data from a suite of 51 reference wetlands in conjunction with analysis of available comparable data from restoration projects initiated within the last decade. The data collected from the reference sites provides a baseline characterization from which we may begin to address uncertainties regarding the elevation, soil, and inundation ranges required by native tidal wetland vegetation. Specific objectives of the analyses of data from these reference wetland sites were as follows:

1. to begin to quantify the ecological conditions necessary for development of wetland plant communities and tidal channel networks, a critical step in designing restoration projects (Kentula et al. 1992; Steyer et al. 2003; Thayer et al. 2005)

2. to demonstrate a method for statistically evaluating the effectiveness of restoration actions as described in the RME plan for the LCRE (Johnson et al. 2008).

We understand that other studies have recently begun to evaluate restoration site data in the LCRE (e.g., Johnson et al. 2012, Ennis 2009, Parametrix 2009) and wish to stress that this study is not meant to replace or undermine those efforts. This effort is simply intended to provide a standard, repeatable method that could be applied to compare restoration sites to reference sites as one means of evaluating restoration success. 


\subsection{Collaboration}

This study would not have been possible without the collaboration of multiple individuals and organizations through various research programs and restoration projects. As part of the original RS study, we collaborated with the Cumulative Ecosystem Response to Restoration program and the Ecosystem Monitoring program to maximize the number of sites we were able to include in the study (Borde et al. 2011). For the current analysis phase, we have used data from the reference sites included in the previous phase of the study (43 sites) and additional data from sites that were part of the Ecosystem Monitoring program (6 sites) and the Tidal Freshwater Research program ( 2 sites). The latter set of sites and resulting data are appropriate inclusions in the current analysis because the additional sites are also relatively undisturbed wetland sites. Restoration site data analyzed for this report were collected by the following organizations using standardized methods as outlined in the Protocols when possible (funding agency provided in parentheses):

- Pacific Northwest National Laboratory (PNNL) (USACE)

- Columbia River Estuary Study Taskforce (CREST) (BPA)

- Columbia Land Trust (CLT) (BPA)

- U.S. Fish and Wildlife Service (USFWS) (USACE)

- Scappoose Bay Watershed Council (BPA)

- Parametrix (BPA).

\subsection{Report Organization}

In Section 2, we outline the methods used to analyze the data from the reference sites and the methods employed to compare these results to restoration site data. The results are presented and discussed in Section 3. First, we describe the hydrologic and vegetation patterns found through our analysis. Second, we provide the results of the comparisons we conducted between reference and restoration site data. Our conclusions and recommendations are provided in Section 4. We summarize our conclusions regarding ecological zonation in the estuary and also evaluate the usefulness of the metrics used for comparison between reference and restoration sites. Finally, we provide recommendations for future efforts. Sources cited in the text are listed in Section 5. Appendices A through C provide additional detail on site water temperatures and plants observed on the reference and study sites, as well as detailed maps of all the sites examined in this study. 


\subsection{Methods}

Our methods for reference wetland site selection, data collection, and data summarization are detailed in the RS study 2010 final report (Borde et al. 2011) and accordingly will not be described in full here. The methods we present here pertain to the selection of restoration sites for inclusion in this study, data summarization for the restoration sites, and data analysis for both reference and restoration sites.

\subsection{Study Sites}

We included 51 reference sites and 10 restoration sites in this study (Figure 2.1). Site selection criteria for the reference sites included habitat type, location, hydrogeomorphic setting, access, proximity to known restoration efforts, and access, as described in Borde et al. (2008a). Despite an extensive reconnaissance effort, only a very limited number of sites met these criteria, so a random selection of sites was not possible. However, efforts were made to sample a broad distribution of sites both spatially and in all wetland types (forested, shrub, and emergent).

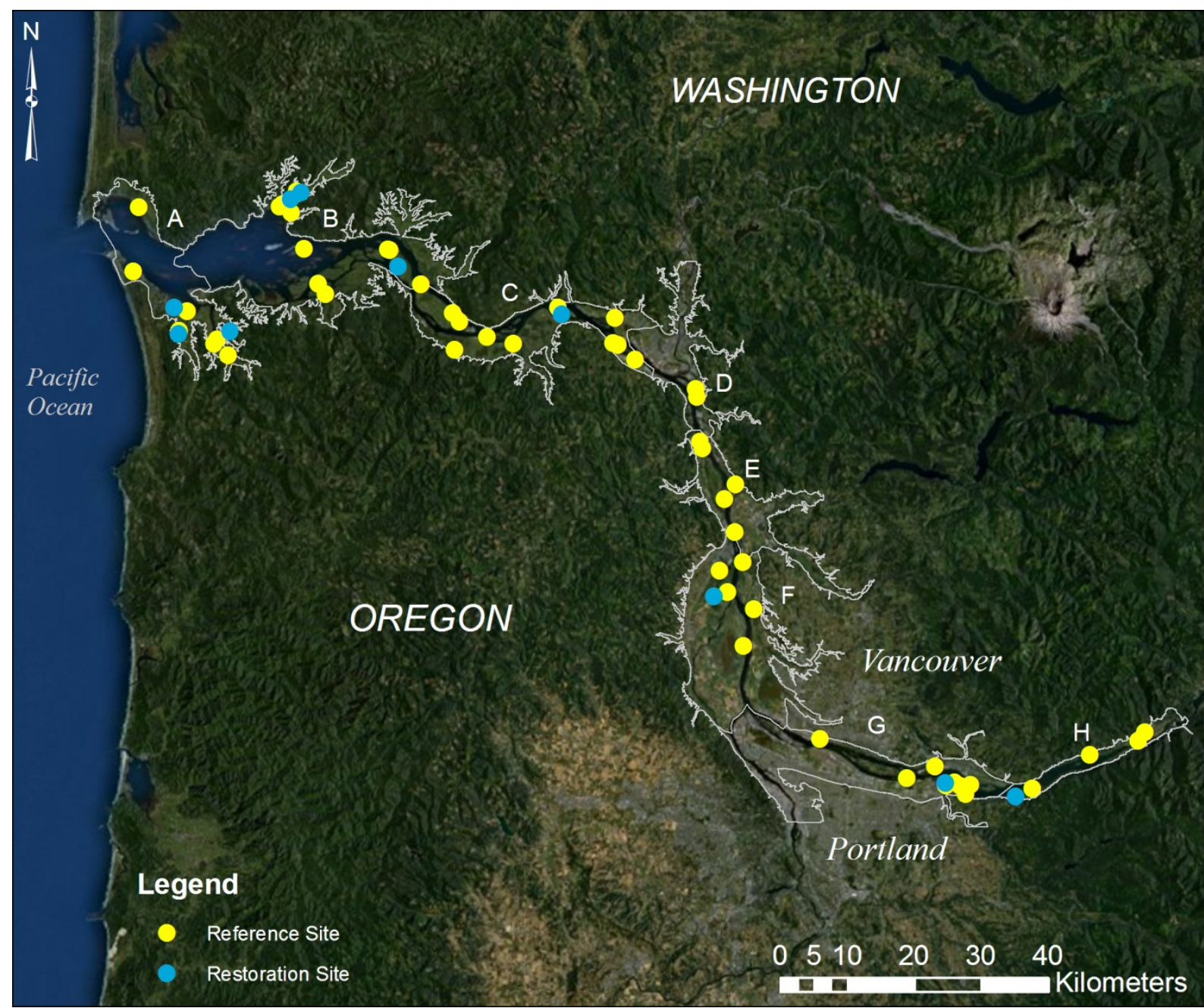

Figure 2.1. Reference and restoration sites in the lower Columbia River and estuary. 
Information gathered in this study helps to illuminate our understanding of the trajectory of restoration sites progressing from a state of early development through successional stages to a stable and resilient state more like undisturbed reference sites. Likewise, three categories of sites are included in this study, as follows:

- least-disturbed habitat - These sites include several specific habitat types, such as brackish marshes, tidal freshwater marshes, tidal freshwater shrub/scrub, tidal freshwater forested swamps (dominated by Sitka spruce), and riparian woodlands (dominated by Black cottonwood, Oregon ash and Pacific willow). Some of these sites were present on the 1880 historical maps, while others have developed since that time. However, none of the sites are a result of direct physical disturbances at the sites. These sites provide the most stable endpoint on the trajectory for comparison to restoration sites.

- previously breached habitat - These sites are previously diked areas that were breached either by natural forces or by intentional restoration actions 10 to 50 years ago. The sites have begun their progression back to a pre-diked state and therefore provide data points along the restoration trajectory.

- created habitat - These island sites were created from dredged material placement. The age of these sites can be estimated and the structure and function evaluated to predict the potential restoration trajectories for these types of habitats.

More discussion regarding the distinction between these types of sites is provided in Borde et al. (2011). For the analyses in this report, all types of sites were included and the history of the sites was used to provide context for the results.

The reference sites used in this study are listed in Table 2.1, and maps of each site are included in Appendix C. Each site was given a code, which will be used throughout the rest of the report. In general, the first two letters of the code represent the site initials and the last letter designates the type of site. For example, CCR represents the Coal Creek Riparian site. The type designations are as follows:

S swamp (a forested evergreen tree dominated wetland) shrub (shrub dominated wetland)

$\mathrm{R}$ riparian (a forested deciduous tree dominated wetland)

M marsh (an herbaceous, emergent wetland; some were present on historical maps from the $1880 \mathrm{~s}^{1}$ )

B previously diked marsh (breached accidentally or for restoration more than 10 years ago)

C created marsh (not present on historical maps and likely due to placement of dredged material).

The restoration sites were selected based primarily on three criteria: 1) the project had been completed for at least one year, 2) post-restoration monitoring data had been collected, and 3) data were available. The ten sites that best met these criteria were included in this study, as summarized in Table 2.2. For many of these restoration sites, data for all of the metrics that were sampled at the reference sites were unavailable, so comparative analyses were conducted on metrics with available data only.

\footnotetext{
${ }^{1}$ Historical maps for the Columbia River are available online at http://historicalcharts.noaa.gov/ and were recently georeferenced and digitized (Burke 2010).
} 
Table 2.1. Reference sites included in this study.

\begin{tabular}{|c|c|c|c|c|c|}
\hline Site Name & Site Code & $\begin{array}{l}\text { Distance from Col. } \\
\text { River mouth (rkm) }\end{array}$ & Reach & $\begin{array}{c}\text { Habitat } \\
\text { Type }\end{array}$ & Historical Class \\
\hline Trestle Bay & TBB & 12 & $\mathrm{~A}$ & marsh & breach \\
\hline Chinook River Mouth & $\mathrm{CHM}$ & 12 & A & marsh & least-disturbed \\
\hline Fort Clatsop & FCB & 19 & A & marsh & breach \\
\hline Mouth Lewis \& Clark River & LCM & 20 & A & marsh & least-disturbed \\
\hline Haven Island & HIB & 23 & A & marsh & breach \\
\hline Cooperage Slough & CSM & 23 & A & marsh & least-disturbed \\
\hline Grant Island & GIM & 23 & A & marsh & least-disturbed \\
\hline Crooked Creek & $\mathrm{CCS}$ & 37 & B & forested & least-disturbed \\
\hline Secret River Swamp & SRS & 37 & B & forested & least-disturbed \\
\hline Seal Slough & SSS & 37 & B & forested & least-disturbed \\
\hline Secret River Marsh & SRM & 37 & B & marsh & least-disturbed \\
\hline Miller Sands & MSC & 39 & B & marsh & created \\
\hline Karlson Island 2 & KIS & 40 & B & forested & least-disturbed \\
\hline Karlson Island & KIB & 41 & B & marsh & breach \\
\hline Welch Island & WIM & 53 & B & marsh & least-disturbed \\
\hline Welch Island & WIS & 53 & B & shrub & least-disturbed \\
\hline Ryan Island & RIM & 61 & $\mathrm{C}$ & marsh & least-disturbed \\
\hline Jackson Island & $\mathrm{JIC}$ & 71 & $\mathrm{C}$ & marsh & created \\
\hline Whites Island & WHC & 72 & $\mathrm{C}$ & marsh & created \\
\hline Westport Slough & WSS & 73 & $\mathrm{C}$ & shrub & least-disturbed \\
\hline Wallace Island - west & WAC & 77 & $\mathrm{C}$ & marsh & created \\
\hline Clatskanie River - Anunde Is. & CRM & 80 & $\mathrm{C}$ & marsh & least-disturbed \\
\hline Gull Island & GUC & 89 & $\mathrm{C}$ & marsh & created \\
\hline Coal Creek Slough & $\mathrm{CCR}$ & 98 & $\mathrm{C}$ & forested & least-disturbed \\
\hline Lord Island 1 & LI1 & 99 & $\mathrm{C}$ & marsh & created \\
\hline Lord Island 2 & LI2 & 100 & $\mathrm{C}$ & marsh & created \\
\hline Dibblee Slough & DSC & 104 & $\mathrm{C}$ & marsh & created \\
\hline Cottonwood Island 1 & CI1 & 113 & $\mathrm{D}$ & marsh & created \\
\hline Cottonwood Island 2 & $\mathrm{CI} 2$ & 114 & $\mathrm{D}$ & marsh & created \\
\hline Sandy Island 1 & SI1 & 121 & $\mathrm{E}$ & marsh & created \\
\hline Sandy Island 2 & $\mathrm{SI} 2$ & 123 & E & marsh & created \\
\hline Martin Island & MIM & 129 & $\mathrm{E}$ & marsh & least-disturbed \\
\hline Goat Island & GIC & 131 & $\mathrm{E}$ & marsh & created \\
\hline No-name Island & NNI & 136 & $\mathrm{E}$ & marsh & created \\
\hline Gee Creek & GCR & 141 & $\mathrm{~F}$ & forested & least-disturbed \\
\hline Scappoose Bay & SBM & 143 & $\mathrm{~F}$ & marsh & least-disturbed \\
\hline Cunningham Lake & CLM & 145 & $\mathrm{~F}$ & marsh & least-disturbed \\
\hline Campbell Slough & CS1 & 149 & $\mathrm{~F}$ & marsh & least-disturbed \\
\hline Sauvie Island East Slough & $\mathrm{SSC}$ & 154 & $\mathrm{~F}$ & marsh & created \\
\hline Water Resources Center & WRC & 175 & G & marsh & least-disturbed \\
\hline McGuire Island & MIC & 190 & G & marsh & created \\
\hline
\end{tabular}


Table 2.1. (contd)

\begin{tabular}{lccccc}
\hline \multicolumn{1}{c}{ Site Name } & Site Code & $\begin{array}{c}\text { Distance from Col. } \\
\text { River mouth (rkm) }\end{array}$ & Reach & $\begin{array}{c}\text { Habitat } \\
\text { Type }\end{array}$ & Historical Class \\
\hline Washougal River mouth & WRM & 195 & G & marsh & least-disturbed \\
Sandy River Channel (old) & OSR & 196 & G & marsh & least-disturbed \\
Sandy River Delta (old) & OSM & 198 & G & marsh & least-disturbed \\
Gary Island & GAM & 200 & G & marsh & least-disturbed \\
Chattham Island & CIC & 201 & G & marsh & created \\
Reed Island & RIC & 201 & G & marsh & created \\
Sand Island (Rooster Rock) & SIM & 211 & H & marsh & least-disturbed \\
Franz Lake & FLM & 221 & H & marsh & least-disturbed \\
Pierce Island & PIM & 228 & H & marsh & least-disturbed \\
Hardy Creek & HCM & 230 & H & marsh & least-disturbed \\
\hline
\end{tabular}

Table 2.2. Restoration sites included in this study.

\begin{tabular}{|c|c|c|c|c|c|c|c|}
\hline Site Name & $\begin{array}{l}\text { Site } \\
\text { Code }\end{array}$ & $\begin{array}{c}\text { Distance } \\
\text { from CR } \\
\text { Mouth } \\
(\mathrm{rkm})\end{array}$ & $\begin{array}{l}\text { Landscape } \\
\text { Setting }\end{array}$ & Location & $\begin{array}{l}\text { Restoration } \\
\text { Year }\end{array}$ & Restoration Action & $\begin{array}{l}\text { Target } \\
\text { Habitat }\end{array}$ \\
\hline Fort Clatsop & $\mathrm{FC}$ & $19^{(\mathrm{a})}$ & Tributary & $\begin{array}{c}\text { Lewis \& } \\
\text { Clark River }\end{array}$ & 2007 & $\begin{array}{l}\text { Hydrologic Reconnection - } \\
\text { tide gate to bridge }\end{array}$ & $\begin{array}{l}\text { Forested } \\
\text { Wetland }\end{array}$ \\
\hline Vera Slough & VS & 19 & Bay & Youngs Bay & 2005 & $\begin{array}{l}\text { Hydrologic Reconnection - } \\
\text { tide gate replacement }\end{array}$ & $\begin{array}{l}\text { Emergent/ } \\
\text { Shrub } \\
\text { Wetland }\end{array}$ \\
\hline Walluski & WA & $19^{\text {(a) }}$ & Tributary & $\begin{array}{l}\text { Walluski } \\
\text { River }\end{array}$ & 2006 & $\begin{array}{l}\text { Hydrologic Reconnection - } \\
\text { dike breach }\end{array}$ & $\begin{array}{l}\text { Forested } \\
\text { Wetland }\end{array}$ \\
\hline $\begin{array}{l}\text { Devil's } \\
\text { Elbow }\end{array}$ & $\mathrm{DE}$ & $37^{(\mathrm{a})}$ & Tributary & Grays River & 2004 & $\begin{array}{l}\text { Hydrologic Reconnection - } \\
\text { dike breach }\end{array}$ & $\begin{array}{l}\text { Forested } \\
\text { Wetland }\end{array}$ \\
\hline $\begin{array}{l}\text { Kandoll } \\
\text { Farm }\end{array}$ & KF & $37^{(\mathrm{a})}$ & Tributary & Grays River & 2005 & $\begin{array}{l}\text { Hydrologic Reconnection- } \\
\text { tide gate to } 13 \text { ' culverts }\end{array}$ & $\begin{array}{l}\text { Forested } \\
\text { Wetland }\end{array}$ \\
\hline $\begin{array}{l}\text { Tenasillahee } \\
\text { Island }\end{array}$ & $\mathrm{TI}$ & 57 & Island & Mainstem & 2007 & $\begin{array}{l}\text { Hydrologic Reconnection - } \\
\text { tide gate replacement }\end{array}$ & $\begin{array}{l}\text { Emergent/ } \\
\text { Shrub } \\
\text { Wetland }\end{array}$ \\
\hline Crims Island & $\mathrm{CI}$ & 90 & Island & Mainstem & 2005 & $\begin{array}{l}\text { Hydrologic Reconnection - } \\
\text { excavation }\end{array}$ & $\begin{array}{l}\text { Emergent } \\
\text { Wetland }\end{array}$ \\
\hline $\begin{array}{l}\text { Hogan } \\
\text { Ranch }\end{array}$ & HR & 146 & Mainland & $\begin{array}{l}\text { Scappoose } \\
\text { Bay }\end{array}$ & 2004 & $\begin{array}{l}\text { Enhancement - cattle } \\
\text { exclusion and plantings }\end{array}$ & $\begin{array}{l}\text { Emergent } \\
\text { Wetland }\end{array}$ \\
\hline $\begin{array}{l}\text { Sandy River } \\
\text { Delta }\end{array}$ & SRD & 196 & Delta & Mainstem & $2005 ; 2006$ & Enhancement - plantings & $\begin{array}{l}\text { Riparian } \\
\text { Forest }\end{array}$ \\
\hline Mirror Lake & ML & 208 & Mainland & Mainstem & $2005 ; 2008$ & $\begin{array}{l}\text { Enhancement - fish passage } \\
\text { improvement and plantings }\end{array}$ & $\begin{array}{l}\text { Emergent } \\
\text { Wetland/ } \\
\text { Riparian }\end{array}$ \\
\hline
\end{tabular}

(a) These sites are located up tributaries. In these cases, the distance from the Columbia River mouth represents the distance to the mouth of the tributary, not the distance up the tributary. 


\subsection{Data Management}

Data from the RS study were organized and normalized (i.e., ensuring consistency and reducing redundancy) as part of previous and concurrent efforts (Borde et al. 2011, 2012). Data were gathered from restoration projects that were known to have data for at least two metrics (Table 2.3). However, before analyses could be performed, data from the restoration sites needed to be organized, normalized, processed, and combined with the RS datasets. For example, vegetation data were updated to use the most recent nomenclature, and all data were transferred to continuous datasets with consistent units. In addition, water pressure data were corrected for barometric pressure and converted to water surface elevation. All metrics required some level of manipulation prior to analysis.

Table 2.3. Metrics for which data were available from the restoration sites included in this study.

\begin{tabular}{|c|c|c|c|c|c|c|c|c|}
\hline Site Name & Code & $\begin{array}{c}\text { Distance } \\
\text { from CR } \\
\text { Mouth } \\
\text { (rkm) }\end{array}$ & Vegetation & Elevation & $\begin{array}{l}\text { Sediment } \\
\text { Accretion }\end{array}$ & $\begin{array}{c}\text { Channel } \\
\text { Cross } \\
\text { Section }\end{array}$ & Hydrology & Temperature \\
\hline Fort Clatsop & $\mathrm{FC}$ & $19^{(\mathrm{a})}$ & $\mathrm{x}$ & & $\mathrm{x}$ & $\mathrm{x}$ & $\mathrm{x}$ & $\mathrm{x}$ \\
\hline Vera Slough & VS & 19 & $\mathrm{x}$ & $\mathrm{x}$ & $\mathrm{x}$ & $\mathrm{x}$ & $\mathrm{x}$ & $\mathrm{x}$ \\
\hline Walluski & WA & $19^{\text {(a) }}$ & & & $\mathrm{x}$ & $\mathrm{x}$ & & \\
\hline Devils Elbow & $\mathrm{DE}$ & $37^{(\mathrm{a})}$ & & & $\mathrm{x}$ & & & \\
\hline Kandoll Farm & $\mathrm{KF}$ & $37^{(\mathrm{a})}$ & $\mathrm{x}$ & $\mathrm{x}$ & $\mathrm{x}$ & $\mathrm{x}$ & $\mathrm{x}$ & $\mathrm{x}$ \\
\hline Tenasillahee Island & $\mathrm{TI}$ & 57 & & & & & & $\mathrm{x}$ \\
\hline Crims Island & $\mathrm{CI}$ & 90 & $\mathrm{x}$ & $\mathrm{x}$ & $\mathrm{x}$ & $\mathrm{x}$ & $\mathrm{x}$ & $\mathrm{x}$ \\
\hline Hogan Ranch & HR & 146 & $\mathrm{x}$ & & & & & $\mathrm{x}$ \\
\hline Sandy River Delta & SRD & 196 & $\mathrm{x}$ & & & & & \\
\hline Mirror Lake & ML & 208 & $\mathrm{x}$ & & & $\mathrm{x}$ & & $\mathrm{x}$ \\
\hline
\end{tabular}

(a) These sites are located up tributaries. Therefore, the distance from the Columbia River mouth represents the distance to the mouth of the tributary, not the distance up the tributary.

\subsection{Data Analysis}

\subsubsection{Vegetation Distribution Patterns}

The distribution of wetland vegetation and its association with inundation patterns in the tidally influenced Columbia River was explored using data from the reference sites. Five habitat classifications based on the community and historical activities were used to separate wetlands (forested; shrub; marshbreach; marsh-created; and marsh-least-disturbed). At each of the marsh sites, variable numbers of quadrats positioned at roughly $10-\mathrm{m}$ intervals along transects at each site were assessed for the cover of wetland vegetation and elevation (relative to Columbia River Datum, CRD). For each quadrat sampled, the absolute percentage of cover was recorded for each vegetative layer (e.g., canopy, understory). Total cover was defined as the sum of all observed (both unidentified and identified) grasses, ferns, herbs, rushes, and sedges. Relative cover was then calculated as the ratio of the absolute cover divided by the total cover. Only identified grasses, ferns, herbs, rushes, and sedges were used in the analyses on percentage cover (Table 2.4). 
Table 2.4. Classification and number of identified wetland taxa observed within quadrats from marsh sites only.

\begin{tabular}{lccccc}
\hline Plant Type & $\begin{array}{c}\text { Number } \\
\text { of Species }\end{array}$ & $\begin{array}{c}\text { Number of } \\
\text { Observations }\end{array}$ & $\begin{array}{c}\text { Maximum } \\
\text { Absolute Cover } \\
(\%)\end{array}$ & $\begin{array}{c}\text { Used in } \\
\text { Discriminant } \\
\text { Analysis }\end{array}$ & $\begin{array}{c}\text { Number } \\
\text { of } \\
\text { Quadrats }\end{array}$ \\
\hline Algae & 1 & 3 & 5 & No & \\
Arrow-grass & 1 & 37 & 30 & No & 334 \\
Shrub & 13 & 302 & 115 & No & \\
Tree & 3 & 24 & 100 & No & 1614 \\
Grass & 16 & 1898 & 110 & Yes & \\
Fern & 6 & 524 & 95 & Yes & \\
Herb & 105 & 5138 & 100 & Yes & 2455 \\
Rush & 10 & 168 & 100 & Yes & \\
Sedge & 18 & 2241 & 100 & Yes & 2811 \\
Grand Total & 173 & 10,335 & -- & -- & \\
\hline & & & & &
\end{tabular}

Cover data are often patchy and highly variable, and a few large observations can influence the mean and potentially distort a comparative analysis. For highly skewed data with many zeros, the mean can be a poor representation of the typical value in a distribution because it is greatly inflated by a few extreme values (Figure 2.2). The median and 75th percentile, however, are based on ranks and are unaffected by extreme values. Therefore, because of the number of zero observations, the median cover would equal zero, thus the 75th percentile of cover was used to represent the species cover for a given marsh. The average over years for sites visited more than once was also calculated.

Analysis was conducted on the 75th percentile of cover for each plant observed at a site. Plants used in the model were observed at a minimum of three sites and yielded a maximum percentage cover of 5\% at one or more sites. Breakpoints for discrimination of vegetation communities were developed based on several lines of evidence, including salinity, hydrology (sum exceedance value [SEV] see Borde et al. 2011), species distribution, and species richness, and are discussed in Section 3.1.1. As part of this analysis, the probability of occurrence for species in marsh reference sites was calculated by dividing the number of occurrences where the species had the maximum cover $(>20 \%)$ in a quadrat by the total number of quadrats in the estuary. Cluster analysis of least-disturbed marshes was conducted on standardized variables using complete linkage and Euclidean distance (squared distance between observations) and Manhattan distance (absolute difference between observations). Discriminant analysis was conducted based on the location within the river. Breakpoint values in the emergent marsh (EM) model $(\mathrm{EM} 1=40, \mathrm{EM} 2=104, \mathrm{EM} 3=136$, and EM4 = 181) determined the boundaries for the resulting hydro-vegetation zones. 


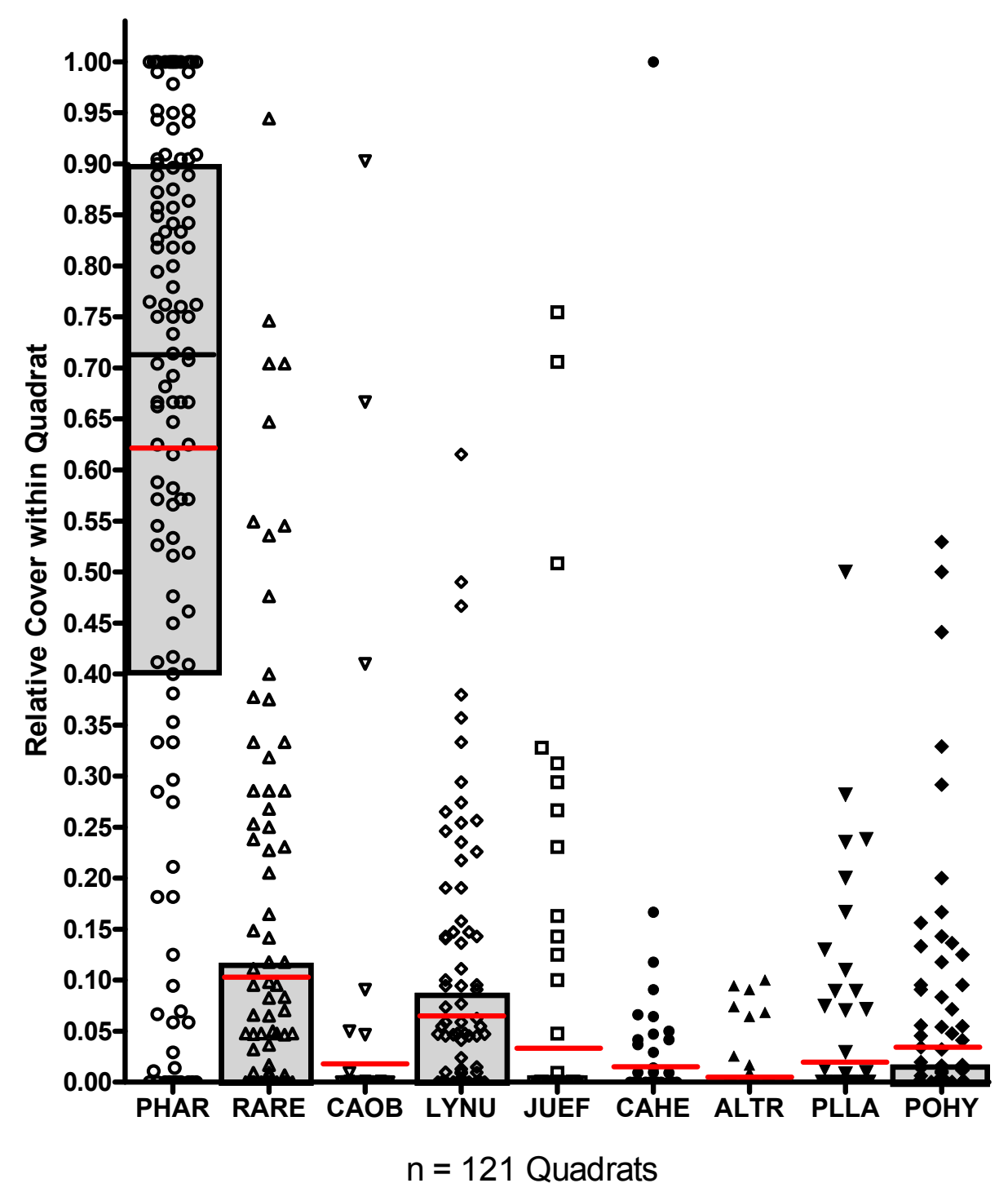

Figure 2.2. Comparison of the mean (red line), median (black line within gray rectangle), and the 25th and 75th percentile (bottom and top of gray rectangle) of vegetation cover data from Kandoll Farm. Species codes (on the $x$-axis) are provided in Appendix A.

\subsubsection{Elevation Distribution of the Major Herbaceous Species}

The elevation distribution for major plant species within a given section of the river based on the EM model was estimated. The data used in the analysis were the relative cover of each species within quadrats for which elevation had been measured. For each elevation (relative to the Columbia River Datum [CRD] and rounded to one decimal place) and species, the 75th percentile of the relative cover from all sites having measurements at that elevation was calculated. For each species, the elevation distribution was characterized by the minimum and maximum elevations for which the 75th percentile was greater than $20 \%$ cover. The species considered in the analysis were those observed at least 20 times. For hydro-vegetation zone 1, the analysis was conducted for those sites on the main stem of the river and within tributaries separately. The species used in these river sections were those observed at least 10 times. 


\subsubsection{Hydrology}

Hydrology and the resulting inundation patterns are an important factor in the distribution of wetland inundation. As part of the analysis of vegetation distribution patterns in the LCRE, we also evaluated inundation. Pressure transducers (HOBO Water Level Data Loggers, Onset Computer Corporation) were deployed when possible at each of the reference sites as a means of logging in situ water level data for one year. Pressure data were corrected for atmospheric pressure and converted to water surface elevation using the surveyed elevation of the sensor. These data were used to calculate the frequency of inundation and the SEV for site-specific marsh elevations.

The frequency of marsh inundation was calculated for the entire period of record (approximately one year) and for the growing season, 22 April-12 October. The growing season is based on the number of frost-free days for the region, as determined by the Natural Resource Conservation Service (NRCS) in the wetland determination table for Clark County, WA (NRCS 2002). The Clark County growing season is used for all the sites in the estuary so that the inundation calculations are standardized to one period. The inundation frequency during the growing season was calculated during daylight hours only (between 0900 hours and 1700 hours). This limitation was employed because of the tidal areas where the timing of the daily high tide can be a factor in the amount of time available for plants to photosynthesize.

The SEV is a single measurement that incorporates magnitude, timing, and duration of surface water flooding and has been used for evaluating the effect of variable water levels on vegetation (Simon et al. 1997; Gowing et al. 2002; Araya et al. 2011). We calculated the SEV using the following equation:

$$
\mathrm{SEV}=\sum_{i=1}^{n}\left(d_{\mathrm{elev}}\right)
$$

where $n$ is the number of hours present in the time period evaluated, and $d_{\text {elev }}$ is the hourly water surface elevation above the average marsh elevation. This differs from previous LCRE studies (Borde et al. 2011, 2012) in which the daily mean water surface elevation was used in the calculation rather than the hourly water level elevation used here. The latter was chosen to ensure we captured daily inundation fluctuations that occur in the more tidally dominated sites. The time periods evaluated were the annual deployment period and the growing season. Both periods were standardized to include the same days in each year, as follows:

- growing season - 22 April to 22 June and 20 August to 13 October (115 days)

- annual deployment period - 20 August to 22 June (of the next year; 306 days).

Adoption of this standardization was necessary because the deployment and retrieval dates for sensors varied in the past, between 21 June and 20 August; to compare calculations from past and current data required that the same time periods be used.

\subsubsection{Reference and Restoration Site Comparison}

Data analysis was conducted for the metrics available from each wetland reference and restoration site. In most cases, summary calculations were made, after which comparisons or statistical tests were applied to the summarized data. 


\subsubsection{Sediment Accretion Rate}

Annual sediment accretion rates were calculated as the difference between annual measurements at sediment stakes deployed at each site (see Borde et al. 2011 and Roegner et al. 2009 for field methods). Rates for reference to restoration sites were plotted for the appropriate hydro-vegetation zone.

\subsubsection{Elevation}

Elevation data were collected at each of the vegetation sample quadrats at three restoration sites (VS, $\mathrm{KF}$, and CI) and at all the reference sites. The data were collected in North American Vertical Datum 1988 (NAVD88) and were converted to mean lower low water (MLLW) below rkm 35 and to the Columbia River Datum (CRD) between rkm 35 and 235 (see Borde et al. 2011 for methods regarding the conversion). The conversion from the terrestrial datum NAVD88 to the water level-related datums allowed comparison of elevations between sites along the estuarine gradient. The data at each site were summarized to determine average, minimum, and maximum elevations for each sample area. These results were than compared between the restoration sites and to the selected reference sites in each hydrovegetation zone.

\subsubsection{Hydrology}

The SEV was calculated for the elevation range of the restoration and the appropriate reference sites sites. The range of values were then plotted together to compare the values at the reference sites to each restoration site.

\subsubsection{Temperature}

Hourly water temperature data were collected in the field using in situ autonomous data loggers for varying time periods between 2005 and 2010. The seven-day running average of the daily maximum (7DADmax) was calculated for seven restoration sites (FC, VS, KF, TI, CI, HR, and ML) and 25 reference sites using MATLAB (The MathWorks, Inc., Natick, Massachusetts). Only the period between March and July was calculated because this coincides with the period of peak juvenile Chinook salmon migration (Sather et al. 2011), and data gaps tended to occur with summer sensor download and launch dates. The data for the restoration sites were plotted relative to the Washington State Department of Ecology (WADOE) surface water criterion of $17.5^{\circ} \mathrm{C}$ (see http://www.ecy.wa.gov/programs/wq/swqs) and compared to the selected reference sites in each hydro-vegetation zone.

\subsubsection{Vegetation}

\section{Bivariate Analysis}

One means of evaluating the vegetation community structure is through bivariate analysis. Simply put, this means comparing two related variables. We chose two commonly occurring vegetation species in the reference sites of each hydro-vegetation zone and plotted them against each other using percentage cover values. Each restoration site and the selected reference sites were plotted on the same graph for comparison. 


\section{Probability of Occurrence}

The probability of occurrence was calculated as a means of comparing the least-disturbed marsh reference sites to restoration sites within each hydro-vegetation zone. The probability of occurrence was calculated by dividing the number of occurrences where the species had the maximum cover $(>20 \%)$ in a quadrat by the total number of quadrats sampled in the estuary. For restoration sites, the probability of occurrence was defined based on cover greater than 14\%. The species plotted for comparison were those observed to have maximum cover greater than or equal to $5 \%$ for least-disturbed-marsh plants, and those plants that occur greater than $10 \%$ at the restoration sites.

\section{Similarity Index}

Similarity indices for herbaceous, shrub, and tree vegetation cover were calculated individually using PCORD Version 5.32 software (McCune and Grace 2002). The data used to calculate similarity between sites were herbaceous species cover, shrub species stem density, and tree species stem density. Data were summarized in a matrix of the mean percentage cover or stem density of each species at each site. All sampled plots were incorporated into the mean for each site, with the exception of tree plantings at Sandy River, which occurred in four subareas numbered 1-4 and were monitored and calculated accordingly. To express dissimilarity, we calculated the Relative Sorensen proportion coefficient, also known as the relativized Manhattan coefficient (Faith et al. 1987), and converted the results to similarity by subtracting from 1.0. Proportion coefficients are "city-block distance measures expressed as proportions of the maximum distance possible" (McCune and Grace 2002, p.47). The Relative Sorensen method uses the Bray-Curtis dissimilarity measure,

$$
D_{i h}=1-\frac{2 \sum_{j=1}^{p} \operatorname{Min}\left(a_{i j}, a_{h j}\right)}{\sum_{j=1}^{p} a_{i j}+\sum_{j=1}^{p} a_{h j}}
$$

on data (for the ith site and the $\mathrm{j}$ species, $\mathrm{a}_{\mathrm{ij}}$ ) that has been made relative by dividing each species cover $(j=1$ to the number of species, $p$ ) by the sample unit totals. In this case, a sample unit total is the total percentage cover of all herbaceous species at a site, total stem density of all tree species at a site, or total stem density of all shrub species at a site.

\subsubsection{Tidal Channels}

Tidal channel morphometrics were calculated for all sites with tidal channels. The length of the primary channel was measured using geographic information system (GIS) data. The channel area, depth, and width at the outlet were calculated based on cross-sectional measurements in the field. The relationship between area at the outlet versus length and channel width versus depth at the outlet were plotted for reference and restoration sites. 


\subsection{Results and Discussion}

We first present the results of our analysis of vegetation patterns found in wetland reference sites, which can be useful for restoration planning and design, followed by a comparison of data from the reference sites and restoration sites. We begin by developing the basis for the distribution of vegetation characteristic of reference sites in the region using available ecological and hydrological data. We then use discriminant function analysis using the vegetation data from the least disturbed sites to provide verification for the observed hydro-vegetation zonation. We conclude the analysis of vegetation patterns by providing the elevational ranges of selected plant species and communities for different zones of the LCRE. Finally, we compare reference sites to restoration sites within each of these zones; evaluating several metrics including accretion rates, elevation, temperature, vegetation, and channel morphology.

\subsection{Vegetation Zonation Data}

\subsubsection{Vegetation Distribution Patterns along the Estuarine Gradient}

We used several different lines of evidence based on vegetation species richness, species composition, salinity, and inundation to determine vegetation distribution patterns along the estuarine gradient. First, species richness differs spatially in the estuary; fewer species are present at the lower and upper ends of the estuary, and species richness is higher in the middle reaches (Figure 3.1). We suspect that the longitudinal gradient (i.e., river mouth to Bonneville Dam) in plant species richness and plant cover is caused by a combination of several factors. Grime (1979) proposed that the major factors structuring species composition and abundance were 1) dominance (competitive exclusion), 2) environmental stress, 3) disturbance, 4) niche differentiation, and 5) colonization. Grace (1999) summarized these factors into a conceptual model.

We believe that all of these factors contribute to the floodplain wetland plant community and that water level dynamics exhibit a strong influence. We believe that the relationship of low richness at the ends of the estuarine gradient and higher richness in the middle region of the gradient is largely due to the 'disturbance' associated with water-level dynamics (i.e., tidal, fluvial), and water properties (i.e., salinity) (Table 3.1). Physical disturbance has been shown to control species richness in many ecosystems (e.g., Levin and Paine 1974, Connell 1978, Bertness and Ellison 1987). Another contributing factor could be the species pool available for colonization of sites (Aarssen and Schamp 2002), which may be greatest at the middle reaches of the lower river.

Species composition also differs along the estuarine gradient; some species have a higher affinity for the tidally dominated areas closer to the mouth and others have a higher affinity for the more fluvialdominated areas, as indicated by the proportional probability of occurrence (Table 3.2). In Table 3.2, the species in the first three columns are likely to occur throughout the estuary, while the remaining species are found primarily in either the lower or the upper portions of the estuary. Sites within hydro-vegetation zones 2 and 3 typically have the highest species diversity because there is overlap between the species that can occur in the lower portion and those that have a higher affinity for the upper portion of the estuary. 

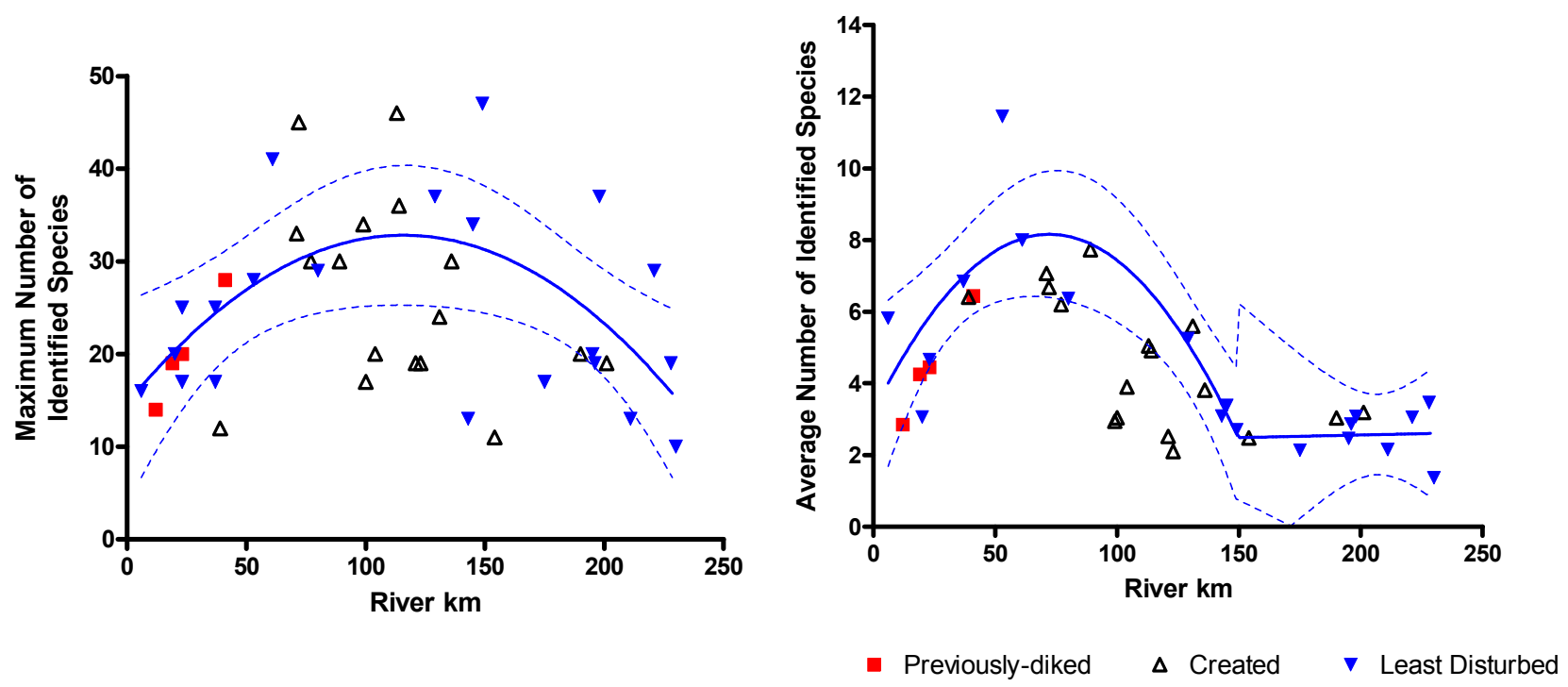

Figure 3.1. Maximum number (upper panel) and average number (lower panel) of species observed at the reference sites versus the distance of the sites from the river mouth. The mid-river section, associated with the peak of the quadratic curves, had significantly more identified species than the lower and upper portions of the river (Kruskal-Wallis; $p=0.008$ ). The fitted curves and the confidence intervals were based on the least-disturbed marsh sites only.

Table 3.1. Relationships between water level dynamics, water properties, and vegetation species richness and cover in the lower Columbia River based on our findings.

\begin{tabular}{|c|c|c|c|}
\hline High cover & $\begin{array}{l}\text { - Low plant diversity } \\
\text { - Stress tolerant and } \\
\text { ruderal } \\
\text { - Euryhaline }\end{array}$ & & \\
\hline Moderate cover & & $\begin{array}{l}\text { - High plant diversity, } \\
\text { - Competitive, stress } \\
\text { tolerant, and ruderal } \\
\text { - Freshwater }\end{array}$ & \\
\hline \multirow[t]{2}{*}{ Low cover } & & & $\begin{array}{l}\text { - Low plant diversity } \\
\text { - Stress tolerant and } \\
\text { ruderal dominated, } \\
\text { - Freshwater }\end{array}$ \\
\hline & $\begin{array}{c}\text { SEV low } \\
\text { (Tidal, regular daily } \\
\text { inundation) }\end{array}$ & $\begin{array}{c}\text { SEV moderate } \\
\text { (Mixed tidal/fluvial, irregular } \\
\text { seasonal inundation) }\end{array}$ & $\begin{array}{c}\text { SEV high } \\
\text { (Fluvial, persistent high } \\
\text { water at freshet) }\end{array}$ \\
\hline
\end{tabular}


Table 3.2. Probability of the most common vegetation species occurring at each marsh reference site (species codes are provided in Appendix A). Sites are ordered by location beginning at the river mouth. Cells highlighted dark green indicate a greater than $50 \%$ probability of occurrence at that site, light green $50-20 \%$, and yellow less than $20 \%$.

\begin{tabular}{|c|c|c|c|c|c|c|c|c|c|c|c|c|c|c|c|c|c|}
\hline $\begin{array}{l}\text { Site } \\
\text { Code }\end{array}$ & rkm & $\frac{\underline{u}}{\underline{a}}$ & $\underset{\mid l}{\overleftrightarrow{|c|}}$ & $\frac{\infty}{0}$ & $\begin{array}{l}\text { 兄 } \\
\text { sิ }\end{array}$ & $\underset{ٍ}{\varrho}$ & $\sum_{U}$ & $\frac{Z}{\frac{1}{n}}$ & 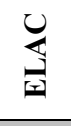 & $\sum_{0}^{5}$ & $\frac{\pi}{3}$ & $\underset{\Sigma}{\Sigma}$ & $\underset{\mathscr{U}}{\overleftarrow{U}}$ & 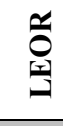 & 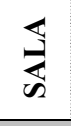 & 苂 & 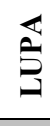 \\
\hline \multicolumn{18}{|c|}{ Zone 1 rkm 0 - 39} \\
\hline \multicolumn{18}{|c|}{ Mainstem } \\
\hline CHM & 12 & & & & & 0.2 & 0.3 & & 0.4 & & 0.9 & & & & & & \\
\hline TBB & 12 & & & & & & & & & & 0.4 & 0.1 & & & & & \\
\hline LCM & 20 & 0.3 & & & 0.1 & & & & & & 0.8 & & 0.1 & & & & \\
\hline SRM-H & 37 & 0.4 & & & 0.6 & & & 0.2 & & & 0.8 & & 0.2 & & & & \\
\hline SRM-L & 37 & 0.4 & 0.2 & & & 0.2 & & 0.2 & & 0.2 & & & 0.4 & & & & \\
\hline MSC & 39 & & & & & 0.4 & & & 0.4 & 0.6 & & 0.3 & & & & & \\
\hline \multicolumn{18}{|c|}{ Tributary } \\
\hline FCB & 19 & 0.3 & 0.2 & 0.5 & 0.3 & & & & & & 0.2 & 0.3 & & & & & \\
\hline CSM & 23 & & & 0.6 & & & & & & & & & 0.5 & & & & \\
\hline GIM & 23 & & & & 0.3 & & & & & 0.2 & 0.7 & & 0.1 & & & & \\
\hline HIB & 23 & 0.4 & 0.1 & & & 0.1 & & & & 0.4 & 0.3 & & 0.3 & & & & \\
\hline \multicolumn{18}{|c|}{ Zone 2 rkm 40 - 103} \\
\hline KIB & 41 & 0.2 & 0.2 & 0.4 & 0.1 & & & 0.1 & & 0.2 & & 0.3 & & & & & \\
\hline WIM & 53 & & & 0.5 & & & & & & & & & & & & & \\
\hline RIM & 61 & 0.3 & 0.1 & & & & & & 0.1 & & 0.6 & & & & & 0.1 & \\
\hline JIM & 71 & 0.4 & 0.2 & & 0.1 & & 0.1 & & 0.1 & 0.3 & 0.5 & & 0.1 & & 0.6 & 0.3 & \\
\hline WHM & 72 & 0.7 & 0.1 & & 0.1 & & & & & 0.1 & 0.3 & 0.1 & & & 0.3 & 0.3 & \\
\hline WAC & 77 & 0.6 & & & & & & & & 0.1 & 0.2 & & & 0.1 & 0.1 & 0.3 & \\
\hline CRM & 80 & 0.8 & 0.1 & & & & 0.1 & & & & & 0.3 & & & 0.5 & 0.2 & \\
\hline GUC & 89 & & 0.6 & 0.3 & & & 0.1 & & & & & 0.4 & & 0.1 & 0.2 & & \\
\hline LI1 & 99 & 0.5 & 0.1 & & & 0.0 & & & & & & 0.0 & & & 0.1 & 0.4 & \\
\hline \multicolumn{18}{|c|}{ Zone 3 rkm 104 - 135} \\
\hline LI2 & 100 & 0.3 & 0.1 & & & & & & 0.1 & & & 0.1 & & 0.1 & 0.6 & & \\
\hline DIB & 104 & 0.6 & 0.6 & & & 0.1 & & & 0.2 & & & & & & 0.2 & 0.1 & \\
\hline CI1 & 113 & 0.5 & 0.4 & 0.1 & & & & & & & & 0.1 & & 0.1 & 0.2 & 0.2 & \\
\hline CI2 & 114 & 0.5 & 0.7 & & & & & & & & & 0.1 & 0.3 & & 0.3 & 0.1 & \\
\hline SI1 & 121 & 0.5 & 0.6 & & & & 0.1 & & & 0.1 & & & 0.1 & & 0.4 & 0.1 & \\
\hline SI2 & 123 & 0.6 & 0.4 & & & & 0.2 & & & & & & & 0.1 & 0.4 & 0.1 & \\
\hline MIM & 129 & 0.5 & 0.5 & 0.3 & & & & & & & & & & 0.1 & 0.2 & 0.3 & 0.2 \\
\hline GIC & 131 & 0.4 & 0.6 & & & 0.1 & & & 0.1 & & & & & 0.1 & & 0.1 & 0.1 \\
\hline DSI & 136 & 0.5 & 0.8 & & & 0.2 & & & & & & & & 0.3 & & 0.1 & 0.1 \\
\hline \multicolumn{18}{|c|}{ Zone 4 rkm 136 - 180} \\
\hline SBM & 143 & 0.6 & 0.4 & & & & & & & & & & & & 1.0 & & \\
\hline CLM & 145 & 0.6 & 0.6 & & & & & & & & & & & & 0.6 & & \\
\hline $\mathrm{CS}$ & 149 & 0.6 & 0.4 & & & & & & & & & & & & 0.4 & & \\
\hline SCM & 154 & 0.4 & 0.3 & & & & & & & & & & & & 0.6 & & 0.1 \\
\hline WRC & 175 & 0.7 & 0.1 & 0.1 & & & & & & & & & & & 0.4 & & 0.2 \\
\hline \multicolumn{18}{|c|}{ Zone 5 rkm 181 -235 } \\
\hline MIC & 190 & 0.4 & 0.5 & 0.2 & & & & & & & & & & & 0.1 & 0.1 & \\
\hline WRM & 195 & 0.9 & & & & & & 0.1 & 0.1 & & & & & & & 0.1 & 0.1 \\
\hline SRD & 196 & 0.9 & 0.4 & & & & & 0.1 & & & & 0.1 & & & 0.2 & 0.3 & \\
\hline OSM & 198 & 0.0 & 0.3 & & & & & & & & & 0.1 & & & 0.1 & 0.2 & 0.1 \\
\hline CIC & 201 & 0.5 & 1.0 & & & & & & & & & & & & & & \\
\hline SIM & 211 & 0.4 & 0.8 & & & & & & & & & & 0.2 & & 0.1 & & 0.1 \\
\hline FLM & 221 & 0.8 & 0.1 & 0.1 & & & & & & & & & & & 0.4 & & 0.0 \\
\hline PIM & 228 & 0.5 & 0.5 & & & & & & & & & & & & & & \\
\hline $\mathrm{HC}$ & 230 & 0.8 & & & & & & & & & & & & & & & \\
\hline
\end{tabular}




\subsubsection{Downstream of River Kilometer 40}

Downstream of rkm 40, salinity is a factor affecting the lower estuary vegetation distribution patterns. Euryhaline species such as Carex lyngbyei (CALY), Oenanthe sarmentosa (OESA), and Lilaeopsis occidentalis (LIOC) are found more frequently below rkm 40 (Table 3.2). Furthermore, from the literature we determined that rkm 40 is a reasonable estimate for the upper limit of salinity intrusion in marshes. Chawla et al. (2008) states rkm 42 is the salinity intrusion limit during low freshet flow (Bonneville Dam outflow $=3160 \mathrm{~m}^{3} / \mathrm{s}$ ). Annual low flows can be as low as $2000 \mathrm{~m}^{3} / \mathrm{s}$ in the dry season, likely resulting in more extended saltwater intrusion. For example, unpublished results show that salinity intrusion extended along the river bottom to Three-Tree Point (rkm 50) during low-flow neap tides in 1990 (David Jay, Portland State University, personal communication, February 22, 2010). Because these estimates are based on salinity values along the river bottom where the higher salinity concentrations are located, we feel $40 \mathrm{rkm}$ is a more conservative estimate of the extent of salinity in the upper portions of the water column that would likely reach the vegetated marsh surface.

\subsubsection{Between River Kilometers 40 and 104}

Salinity is not a factor between rkm 40 and 104, but inundation is predominantly tidally driven. The amount of inundation occurring at all elevations during the entire year is equal to or greater than that during the growing season (see Section 2.3.1.2 in the methods for descriptions of the time periods used in SEV calculation). In Figure 3.2, the red lines represent sites downstream of rkm 104, where a greater amount of inundation occurs in the winter (non-growing season) months at higher elevations of the sites. This is likely driven by winter flooding and winter high tides that occur in this zone. In contrast, the black lines represent sites where most of the inundation occurs during the growing season.

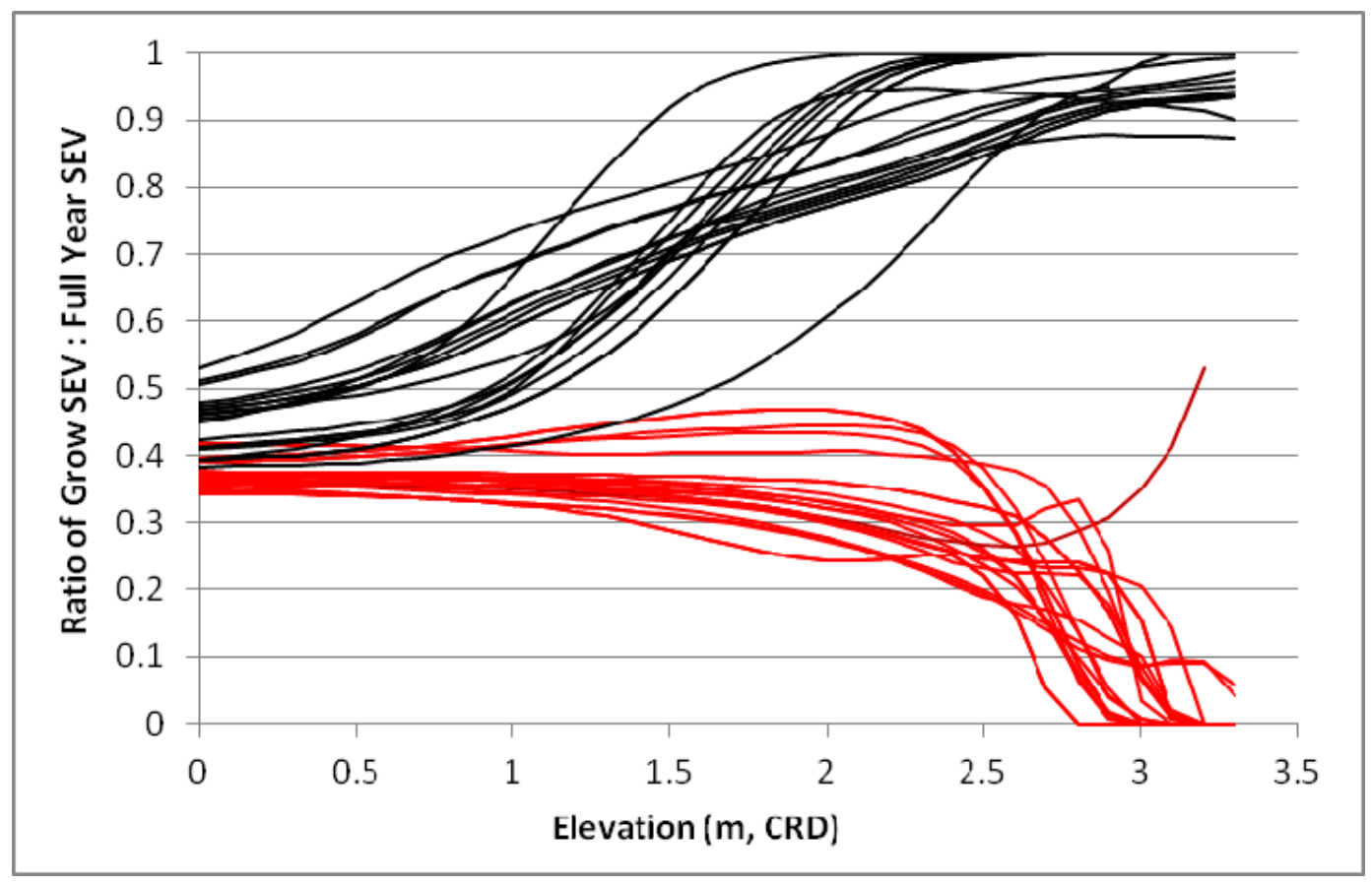

Figure 3.2. Ratio of growing season SEV to the 10-month SEV. Red lines= sites below rkm 104; black lines $=$ sites at or above rkm 104 . 
For least-disturbed marshes only, 13 plant species were observed at three or more locations between rkm 6 and $\mathrm{rkm} 230$; one or more sites had greater than 5\% cover. Cluster analysis on the standardized plant cover denoted eight clusters for two distance measures (Figure 3.3). The two clustering distance measures indicated that marshes from rkm 6 to $\mathrm{rkm} 37$ were at least $50 \%$ similar in terms of species composition and cover. Both methods also indicated that marshes from rkm 53 to rkm 80 were at least $50 \%$ similar. These clusters are consistent with the discriminant cutoff values of EM1 $=40$ and EM2 = 104. Except for site PIM, both methods indicated the same single-site clusters (CSM, SRM-L, WRC, and GAM).
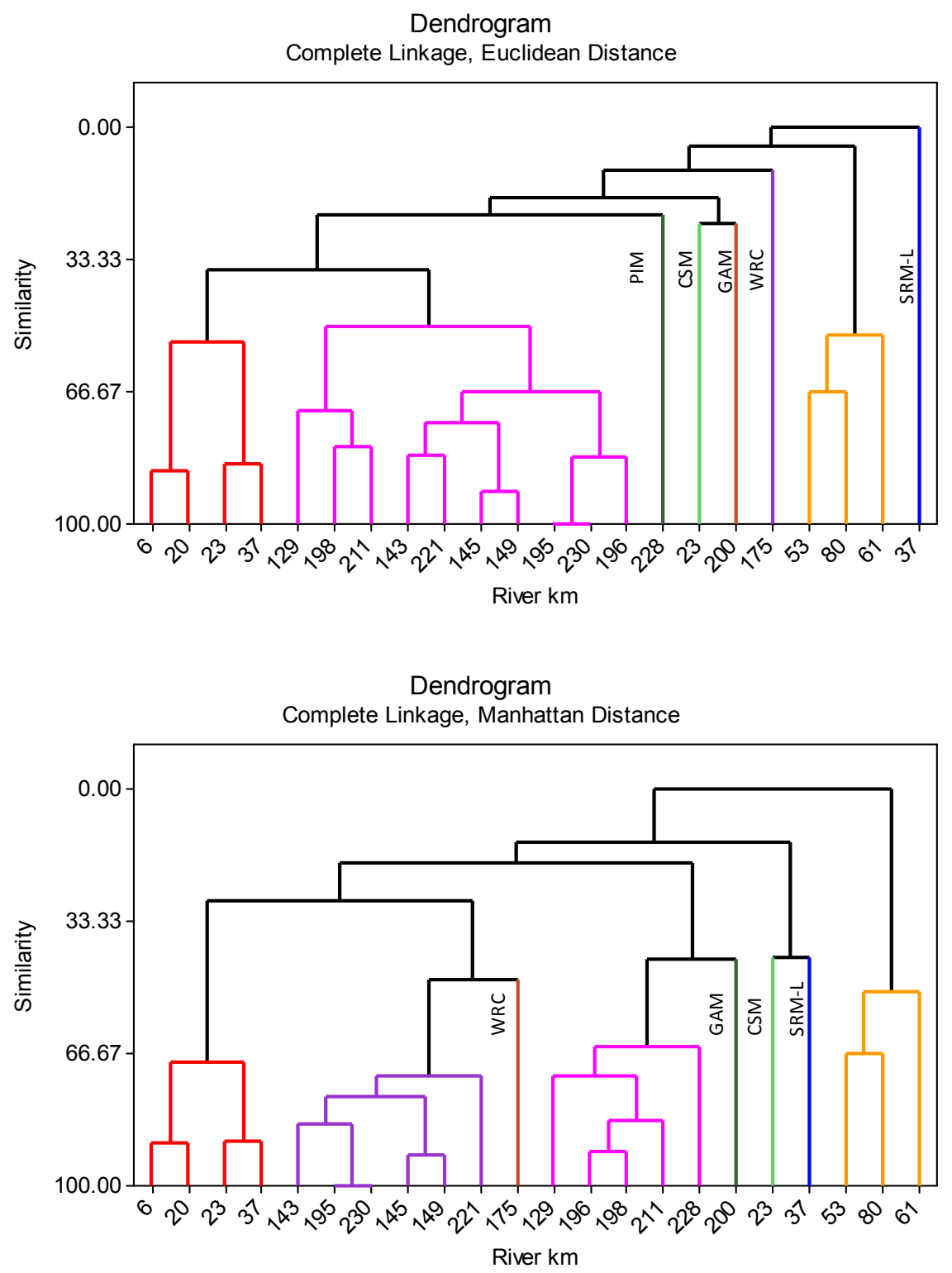

Figure 3.3. Cluster analysis of least-disturbed marshes denoted by river kilometer and color. Colors indicate sites at least $50 \%$ similar in terms of species composition and cover. Site codes are provided for the sites that were least similar to the other least-disturbed sites. 


\subsubsection{Between River Kilometers 104 and 136}

Upstream of rkm 104, there is a shift in the timing of inundation; a greater proportion of the inundation occurs during the growing season and not spread throughout the year (Figure 3.2). However, the magnitude and duration of inundation is still low relative to the zones farther upriver (Figure 3.4).

\subsubsection{Between River Kilometers 136 and 181}

The magnitude and duration of inundation during the growing season begins to increase between rkm 136 and 181. Kukulka and Jay (2003a, p. 9-10) state "tidal energy input dominates the frequency spectrum from the estuary entrance to at least rkm 135. Further the influence of discharge waves was weak seaward of Columbia City at rkm 135." In accordance with these findings, our analysis of SEV at an elevation of $2 \mathrm{~m}$ (CRD) showed that the slope of the $\log _{10}$ growing year SEV as a function of river kilometers is not significantly different from zero downstream of rkm $136(\mathrm{p}=0.96$; Figure 3.4), whereas SEV during the growing season was considerably higher above this point. This indicates that the stronger fluvial influence was a driver of the inundation patterns. In addition, Table 3.2 shows that plants that have a high affinity for the conditions found in the lower part of the estuary are not found upstream of rkm 136.

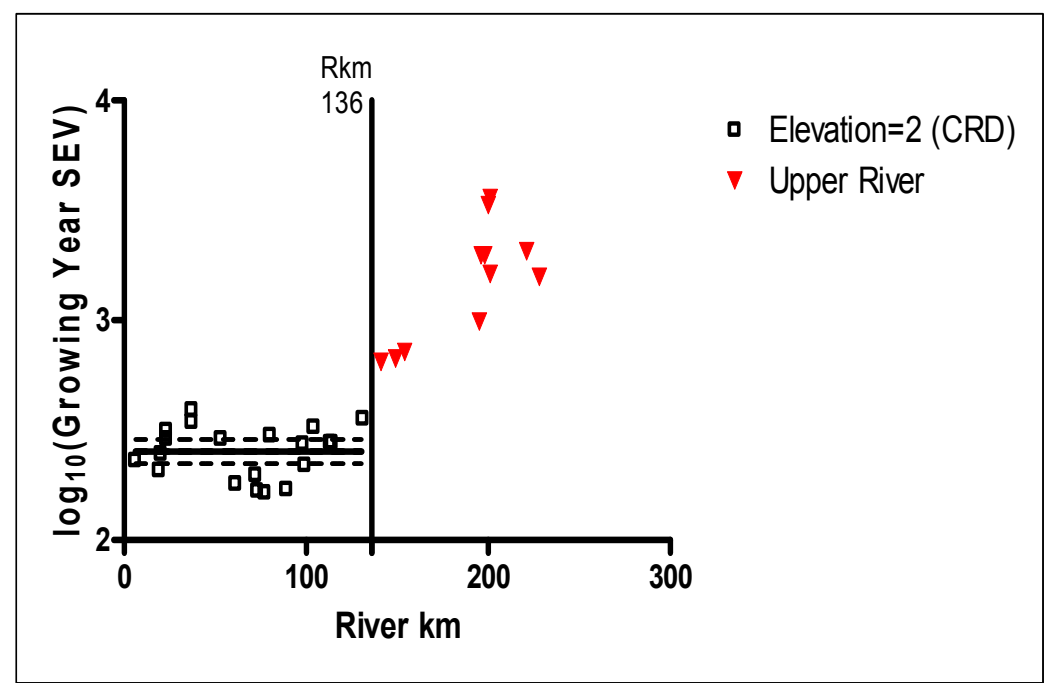

Figure 3.4. The $\log _{10}$ growing season SEV versus river kilometer. In contrast to the slope for the data

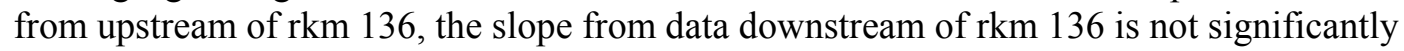
different from zero, indicating less variability in the growing season SEV downstream of rkm 136.

\subsubsection{Above River Kilometer 181}

This zone, the closest to the dam, is the most fluvial-dominated zone. Inundation is very high during the growing season (Figure 3.5) when the spring freshet occurs, and is very low during the rest of the year when flows are very low to moderate. 


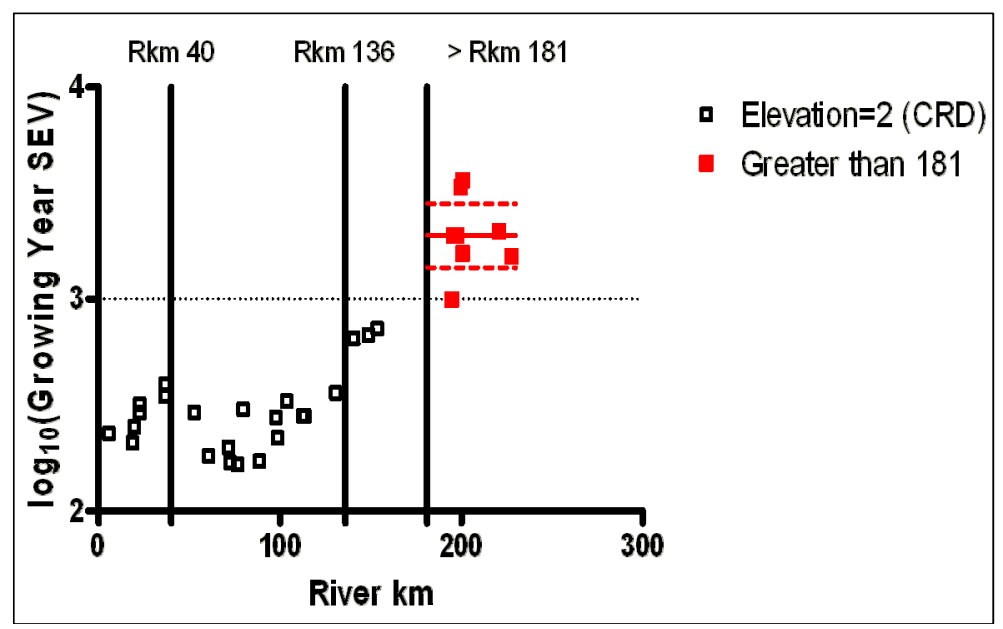

Figure 3.5. The $\log _{10}$ growing year SEV versus river kilometer, with proposed zones delineated. The slope of $\log _{10}$ growing year SEV above rkm 181 was not significantly different from zero.

\subsubsection{Discriminant Function Analysis}

Twenty-two least-disturbed marshes were used in the analysis of cover data for the 13 plant species that occurred at three or more locations between rkm 12 and rkm 230, with greater than $5 \%$ cover at one or more sites. Discrimination using the standardized 75th percentile of cover for all 13 plants successfully classified all sites into four emergent marsh groups (EM1, EM2, EM4, and EM5). There was only one least-disturbed site for EM3, Martin Island (MIM), so it was excluded from the analysis. For the discriminant function, two roots explained $98 \%$ of the variance. Eigen values for each function were greater than 1 , and the Wilks lambda was equal to $0.0001(\mathrm{p}<0.0001)$. The discriminant scores (Score 1 and Score 2) for all sites (including MIM) were calculated and plotted against each other, providing a visual indication that all five groups would have been discriminated (Figure 3.6).

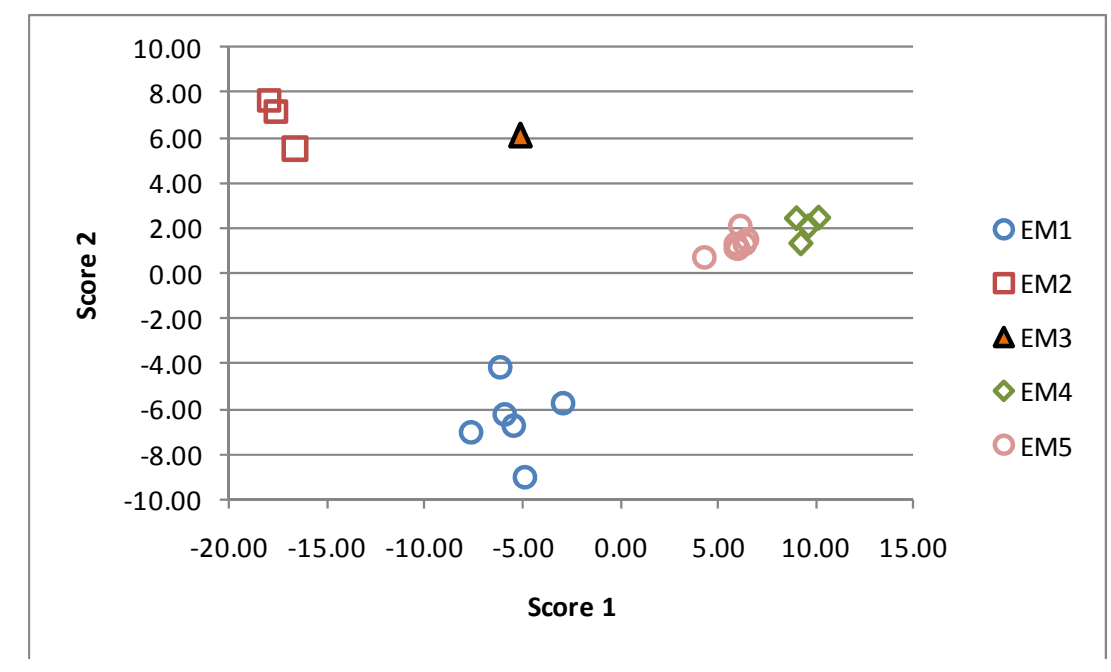

Figure 3.6. Scatter plot of the discriminant scores for five emergent marsh groups. The solid filled triangle was excluded from the discriminant analysis, and scores were calculated without EM3. 
In summary, the hydro-vegetation zones were determined by salinity and inundation patterns and have been shown to result in distinct vegetation species composition and cover groups (EM groups). The boundaries of the observed hydro-vegetation zones are shown in Figure 3.7 and should be evaluated with the following considerations:

1. The verification of the boundaries are based on vegetation from least-disturbed marshes only (see methods for definition of term), while the yellow points on the map in Figure 3.7 represent all reference sites (e.g., emergent, shrub, and forested wetlands and breached, created, and leastdisturbed).

2. The boundary between zones 4 and 5 is a rough estimate due to the lack of sites in this area.

3. The hydrologic data used in this analysis were collected during a limited period, between 2008 and 2010, and different results may be observed using data from different years.

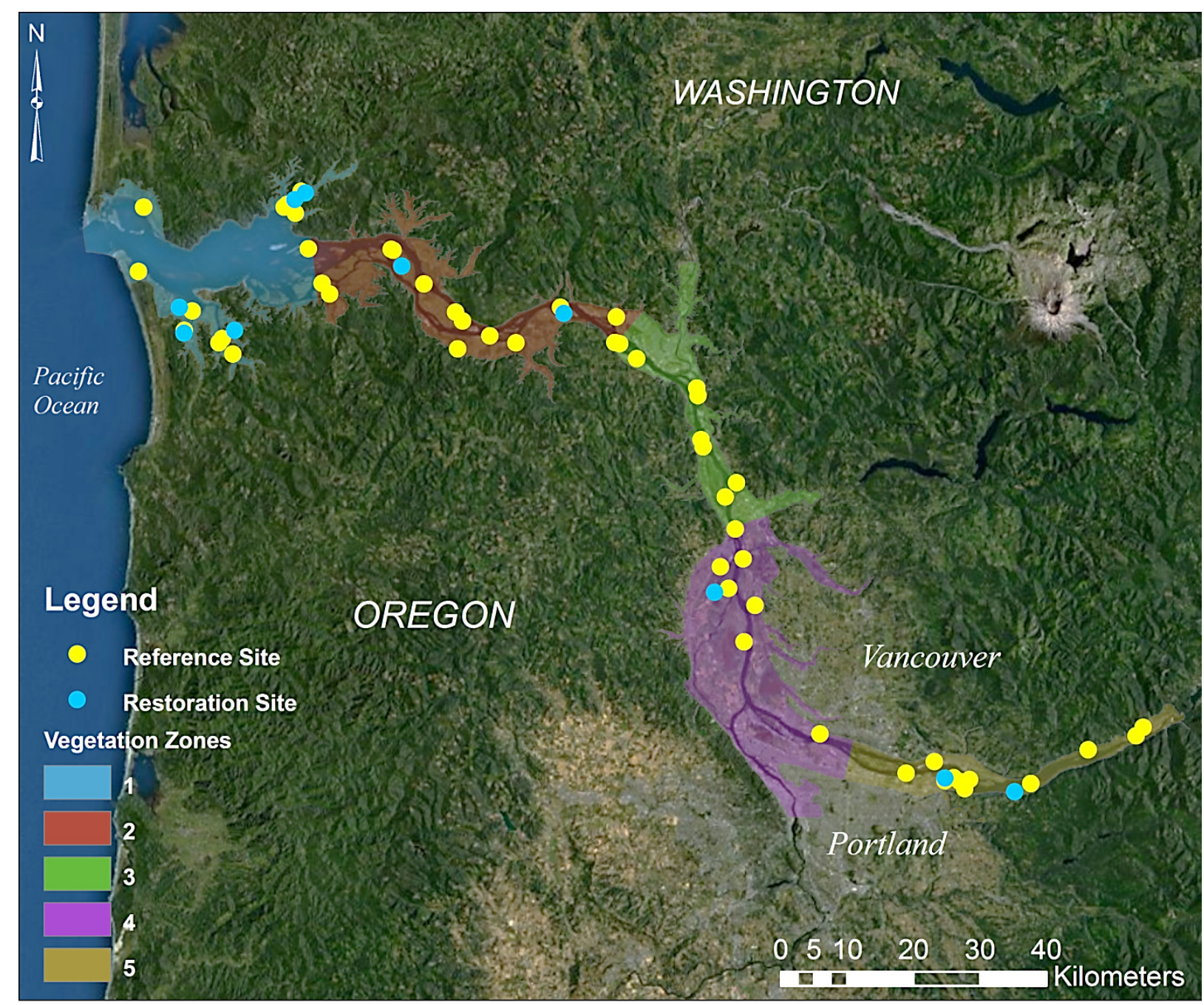

Figure 3.7. Estimated boundaries of the hydro-vegetation zones showing location of reference and restoration sites evaluated in the study. 


\subsubsection{Vegetation Elevation Ranges}

Using the elevation and vegetation data collected at 51 field sites, we are able to develop elevation ranges for the most common species found in each of the hydro-vegetation zones described in the previous section. Table 3.3 shows the elevation range for emergent marshes from two data collection methods: 1) from the vegetation monitoring effort, elevation was determined for the species with the maximum cover in a quadrat having at least $10 \%$ relative cover (using a real-time kinematic (RTK) global positioning system GPS), and 2) elevations were collected at the boundaries of vegetation communities during field mapping (using a hand-held GPS and a RTK GPS) ${ }^{1}$. The first method provides elevation ranges for the dominant species, while the second method covers a broader spatial and elevation range. The zones for forested wetlands are based on the landward extent of Sitka spruce (Picea sitchensis) along the LCRE (estimated to be approximately rkm 75). The average elevations within shrub and forested wetlands are provided in Table 3.4.

Table 3.3. Marsh elevation ranges and the most common species in each of the hydro-vegetation zones.

\begin{tabular}{|c|c|c|c|c|c|c|c|c|c|}
\hline Zone & $\begin{array}{c}\text { Herbaceous } \\
\text { Species }\end{array}$ & Lower & Upper & Marsh Strata & $n$ & $\begin{array}{l}\text { Average } \\
\text { Lower } \\
\text { Elevation }\end{array}$ & $\begin{array}{c}\text { SD } \\
\text { Lower }\end{array}$ & $\begin{array}{l}\text { Average } \\
\text { Upper } \\
\text { Elevation }\end{array}$ & $\begin{array}{c}\text { SD } \\
\text { Upper }\end{array}$ \\
\hline & \multicolumn{3}{|c|}{ Elevation (m, CRD) } & & & \multicolumn{4}{|c|}{ Elevation (m, CRD) } \\
\hline 1 & SCTA & 0.3 & 0.4 & Herbaceous & 5 & 1.1 & 0.7 & 2.6 & 0.6 \\
\hline \multirow[t]{4}{*}{ (mainstem) } & LIOC & 0.5 & 0.9 & Shrub & 3 & 2.5 & 0.6 & NA & NA \\
\hline & CALY & 1.0 & 2.4 & Tree & 2 & 2.6 & 0.8 & NA & NA \\
\hline & CACA & 1.9 & 2.5 & & & & & & \\
\hline & PHAR & 2.5 & 2.7 & & & & & & \\
\hline 1 & $\mathrm{CAOB} / \mathrm{CALY}$ & 0.3 & 2.6 & Herbaceous & 4 & 0.9 & 0.6 & 2.7 & 0.2 \\
\hline \multirow[t]{4}{*}{ (tributary) } & SCTA & 2.2 & 2.4 & Shrub & 3 & 2.5 & 0.1 & NA & NA \\
\hline & POAN & 2.4 & 2.7 & Tree & 1 & 3.0 & NA & NA & NA \\
\hline & ATFI & 2.5 & 2.8 & & & & & & \\
\hline & PHAR & 2.3 & 2.7 & & & & & & \\
\hline \multirow[t]{4}{*}{2} & SALA & 0.8 & 1.2 & Herbaceous & 9 & 0.9 & 0.2 & 2.2 & 0.3 \\
\hline & ELPA & 0.8 & 1.4 & Shrub & 2 & 2.1 & 0.0 & NA & NA \\
\hline & PHAR & 1.4 & 3.2 & Tree & 1 & 1.9 & NA & NA & NA \\
\hline & CALY/CAOB & 1.5 & 1.7 & & & & & & \\
\hline \multirow[t]{3}{*}{3} & SALA & 0.5 & 1.2 & Herbaceous & 6 & 0.7 & 0.2 & 2.0 & 0.4 \\
\hline & ELPA & 0.6 & 1.5 & Shrub & 3 & 1.9 & 0.4 & NA & NA \\
\hline & PHAR & 1.4 & 2.3 & Tree & 0 & NA & NA & NA & NA \\
\hline \multirow[t]{3}{*}{4} & SALA & 0.8 & 1.4 & Herbaceous & 4 & 1.0 & 0.1 & 2.0 & 0.5 \\
\hline & ELPA & 0.8 & 1.7 & Shrub & 0 & NA & NA & NA & NA \\
\hline & PHAR & 1.3 & 3.8 & Tree & 0 & NA & NA & NA & NA \\
\hline \multirow[t]{3}{*}{5} & ELPA & 0.7 & 1.7 & Herbaceous & 7 & 0.9 & 0.3 & 2.3 & 0.8 \\
\hline & SALA & 0.8 & 0.9 & Shrub & 6 & 1.9 & 0.7 & NA & NA \\
\hline & PHAR & 1.5 & 4.6 & Tree & 4 & 3.4 & 0.9 & NA & NA \\
\hline
\end{tabular}

\footnotetext{
${ }^{1}$ See Borde et al. 2011 for detailed field methods.
} 
Table 3.4. Forested and shrub wetland elevation ranges in the two forested wetland vegetation zones.

\begin{tabular}{lllcccc}
\hline & & & $\begin{array}{c}\text { Average } \\
\text { Lower } \\
\text { Elevation }\end{array}$ & $\begin{array}{c}\text { SD } \\
\text { Lower }\end{array}$ & $\begin{array}{c}\text { Average } \\
\text { Upper } \\
\text { Elevation }\end{array}$ & $\begin{array}{c}\text { SD } \\
\text { Upper }\end{array}$ \\
\cline { 3 - 7 } & Forested/Shrub & & \multicolumn{4}{c}{ Elevation (m, CRD) } \\
\hline $0-74$ & Wetland Strata & $n$ & & & \\
\cline { 3 - 7 } & Shrbaceous & 5 & 1.16 & 0.52 & 3.00 & 0.33 \\
& Shrub & 5 & 2.22 & 0.48 & 3.29 & 0.25 \\
$75-235$ & Tree (PISI) & 4 & 2.44 & 0.54 & 4.31 & 0.95 \\
& Herbaceous & 3 & 1.73 & 1.03 & 3.89 & 1.27 \\
& Shrub & 3 & 2.31 & 0.61 & 3.91 & 1.54 \\
& Tree (POBA/FRLA) & 2 & 2.40 & 0.83 & 4.37 & 1.73 \\
\hline
\end{tabular}

\subsection{Reference and Restoration Site Comparison}

We compared reference sites to restoration sites for several metrics, including accretion rates, elevation, hydrology, temperature, vegetation, and channel morphology. The results presented in Section 3.1 were instrumental in conducting the comparison of restoration to reference sites. Based on the location of the restoration sites, we were able to determine the appropriate reference sites using the hydrovegetation zones as a guide (Table 3.5). In hydro-vegetation zone 1, we also determined the appropriate reference sites based on whether the restoration site was located in a tributary or along the mainstem. The SRD and ML sites were the exception because they are sites that were planted with riparian forested wetland species, for which the hydro-vegetation zones do not apply because they were developed based on extensive sampling of emergent marshes. ${ }^{1}$ The forested reference sites in zone 1 occur downstream of rkm 75 and are dominated by Sitka spruce (PISI).

Table 3.5. Restoration sites and the reference sites within the hydro-vegetation zones.

\begin{tabular}{ccllll}
\hline \multicolumn{3}{c}{ Restoration } & \multicolumn{5}{c}{ Reference Sites } \\
\hline 1 Site & (Tributary) & FC, WA, KF, DE & Forest References: CCS SRS KIS SSS \\
Marsh References: FCB HIB CSM GIM & \\
1 (Mainstem) & VS & CHM TBB LCM SRM MSC & & \\
2 & TI, CI & KIB WIM RIM JIC WHM WAC CRM GUC LI2 \\
4 & HR & SBM SCM DMI WRC CLM CS & \\
NA & SRD, ML & SRR CCR GCR & \\
\hline
\end{tabular}

\footnotetext{
${ }^{1}$ The reference sites for this habitat type (i.e., riparian forested wetland dominated by cottonwood [POBA] and ash [FRLA]) occur starting at approximately rkm 75 and include CCR, GCR, and SRR (Sandy River Reference) sites. The SRR reference site was monitored as part of the ML and SRD restoration planting and was not part of the original Reference Site study.
} 


\subsubsection{Sediment Accretion Rate}

Sediment accretion rates in the reference sites vary across the estuary from -1.5 to $2.5 \mathrm{~cm} /$ year, with the majority of sites having rates between 0.0 and $1.5 \mathrm{~cm} /$ year (Figure 3.8). Sites that fall outside this range could be affected by local conditions or possibly single-year events. The most extreme anomaly is the nearly 8-cm erosion seen at the Sand Island site (SIM) located at rkm 211. One explanation for this erosion is that the site is adjacent to the last remaining unstabilized dune area in the lower Columbia River (as described by Christy and Putera 1993), which may cause significant sedimentation and erosion at the site.

Accretion rates at the restoration sites varied spatially and temporally compared to the reference sites. The restoration sites located in the Grays River watershed (KF and DE) tended to have higher accretion rates than the reference sites in second and third years following the restoration action (Figure 3.9). In contrast, the FC site had very low accretion rates. This site is located in the Lewis and Clark watershed, but so is the FCB reference site which had a higher accretion rate, indicating that low sediment source may not be the reason for the low rates at the $\mathrm{FC}$ site.

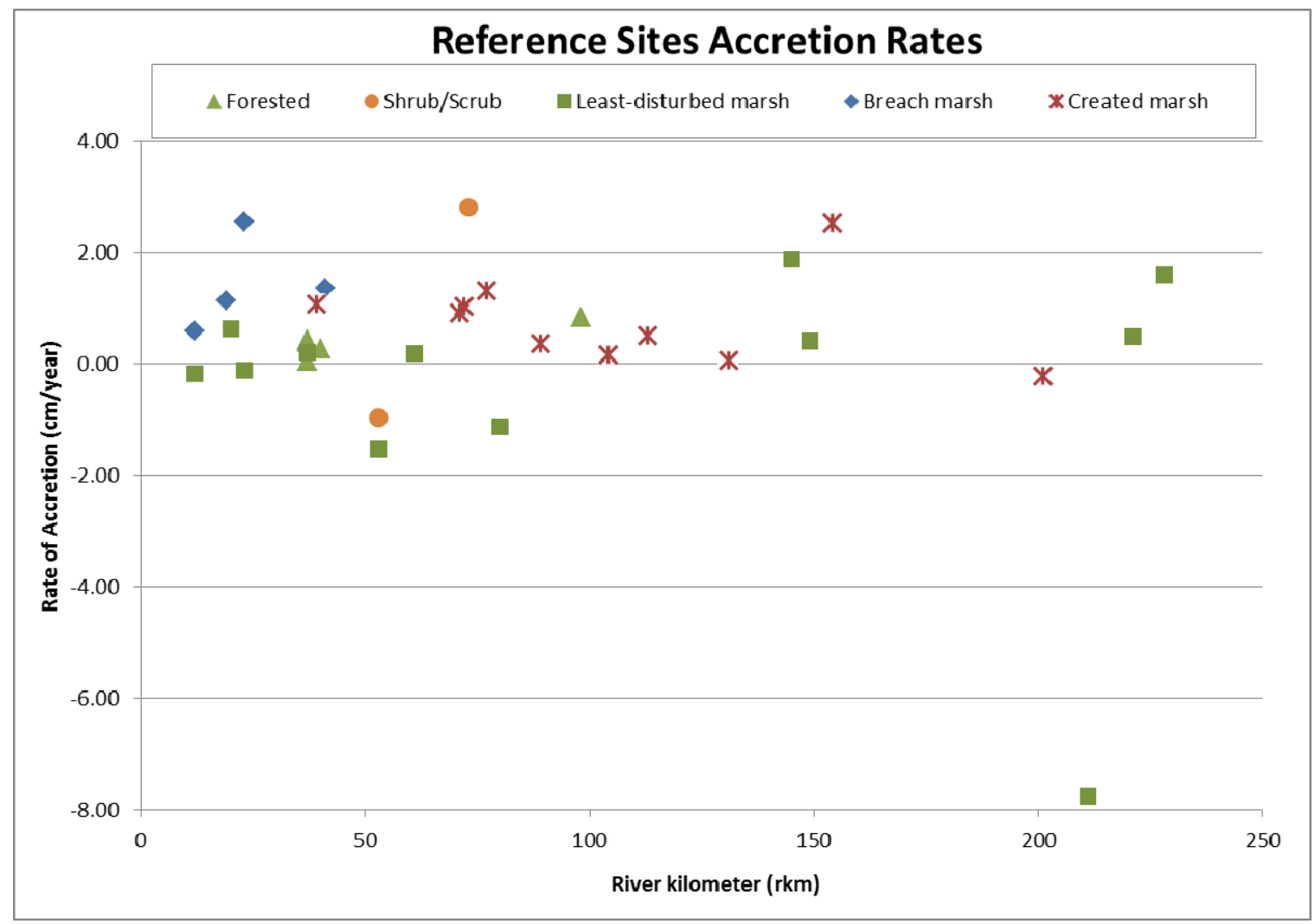

Figure 3.8. Annual accretion rates ( $\mathrm{cm} /$ year) for all reference sites measured in the estuary as part of this study. 


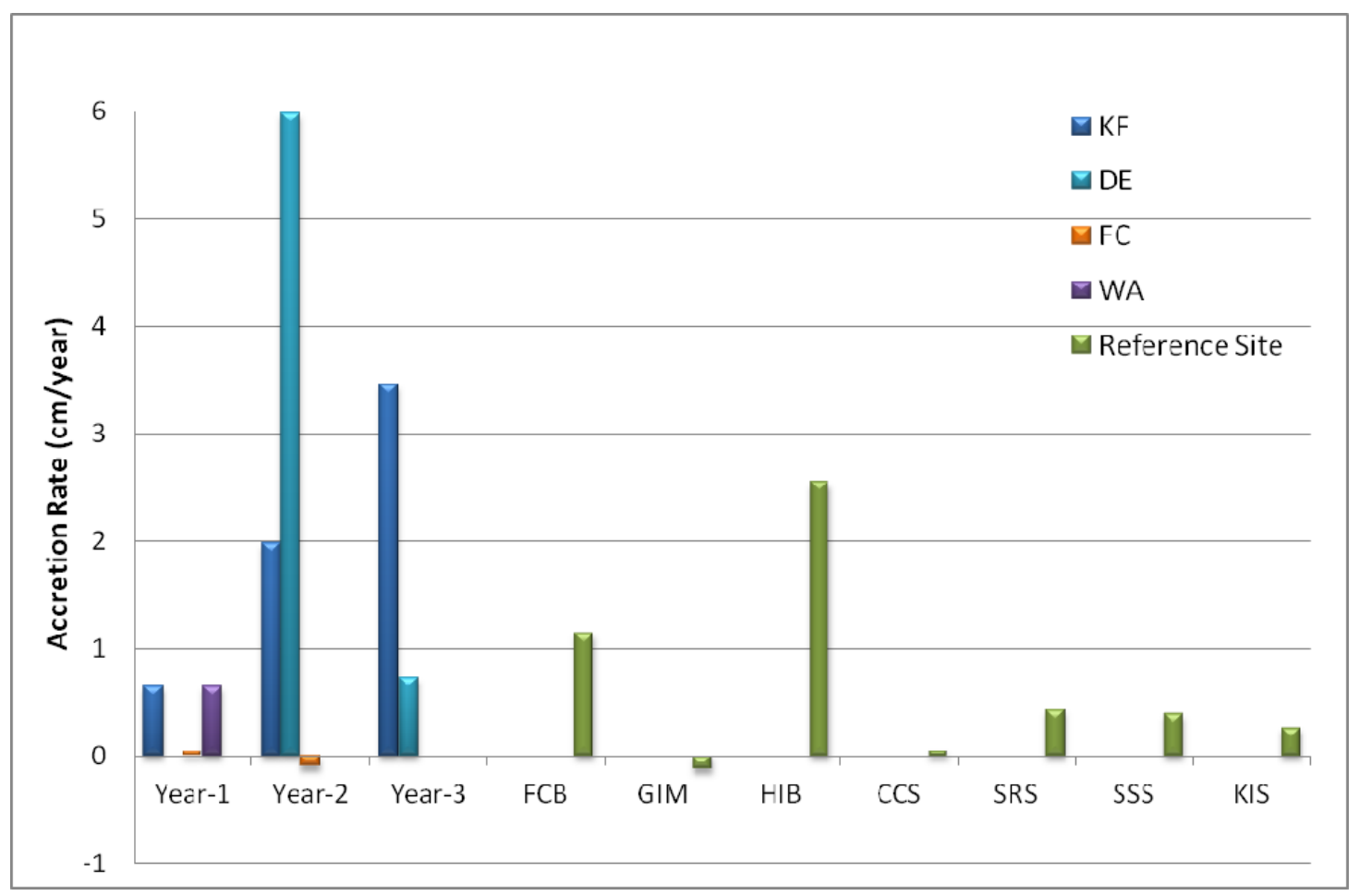

Figure 3.9. Annual accretion and/or erosion rates for the years following the restoration action at four tributary restoration sites compared to reference sites in hydro-vegetation zone 1 . The codes on the $\mathrm{x}$-axis represent the reference sites. Note that the four sites on the right end of the axis are forested sites with higher elevations and therefore lower expected accretion rates.

Accretion rates at VS were very high in the second year after restoration, compared to the reference sites. However, the rate declined in the following year, indicating a potential problem with the natural accretion process at this site (Figure 3.10a). In contrast, the accretion rate at CI steadily increased each year and was similar to the majority of the reference sites (Figure 3.10b). Likely, some interannual variability is contributing to the differences in the reference because most sites were measured for only one year and not always the same year. 

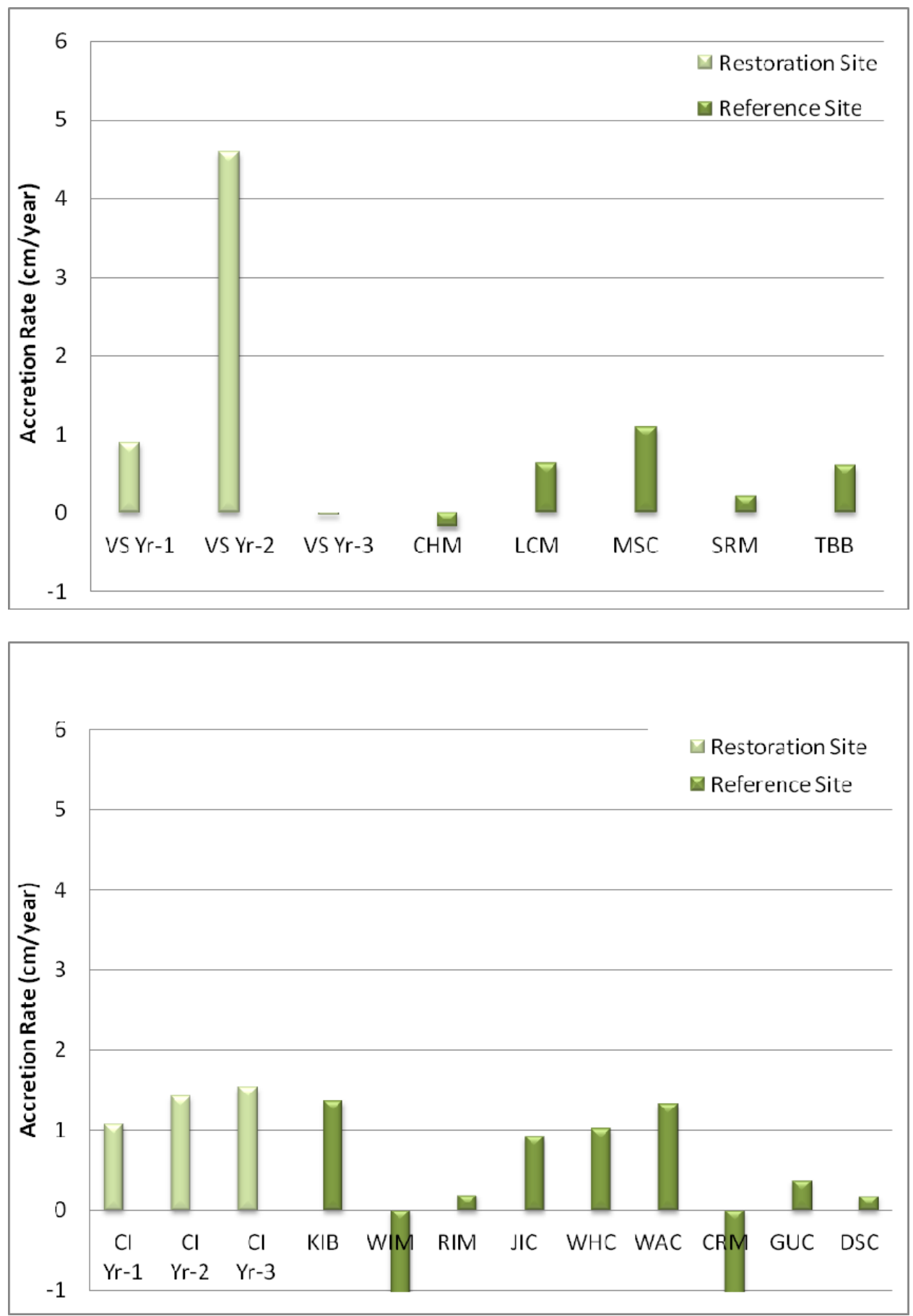

Figure 3.10. Annual accretion and/or erosion rates for all restoration sites in a) Vera Slough (VS) and b) Crims Island (CI) compared to reference sites in the respective hydro-vegetation zones. 


\subsubsection{Elevation}

Elevation at the restoration sites that had been diked (VS and KF) was somewhat lower than that of the selected reference sites (Figure 3.11). The VS site elevation was most similar to SRM, the lowest marsh reference site measured, indicating that given enough time, the VS site will likely colonize with low-elevation marsh species. The average elevation at KF was lower than the average elevation at all other tributary reference sites except HIB, another previously diked and breached site. The highest average elevations were measured at the forested reference sites (SSS, SRS, CCS, and KIS), as would be expected for a wetland farther along the successional gradient in the LCRE (Fox et al. 1984).

a)
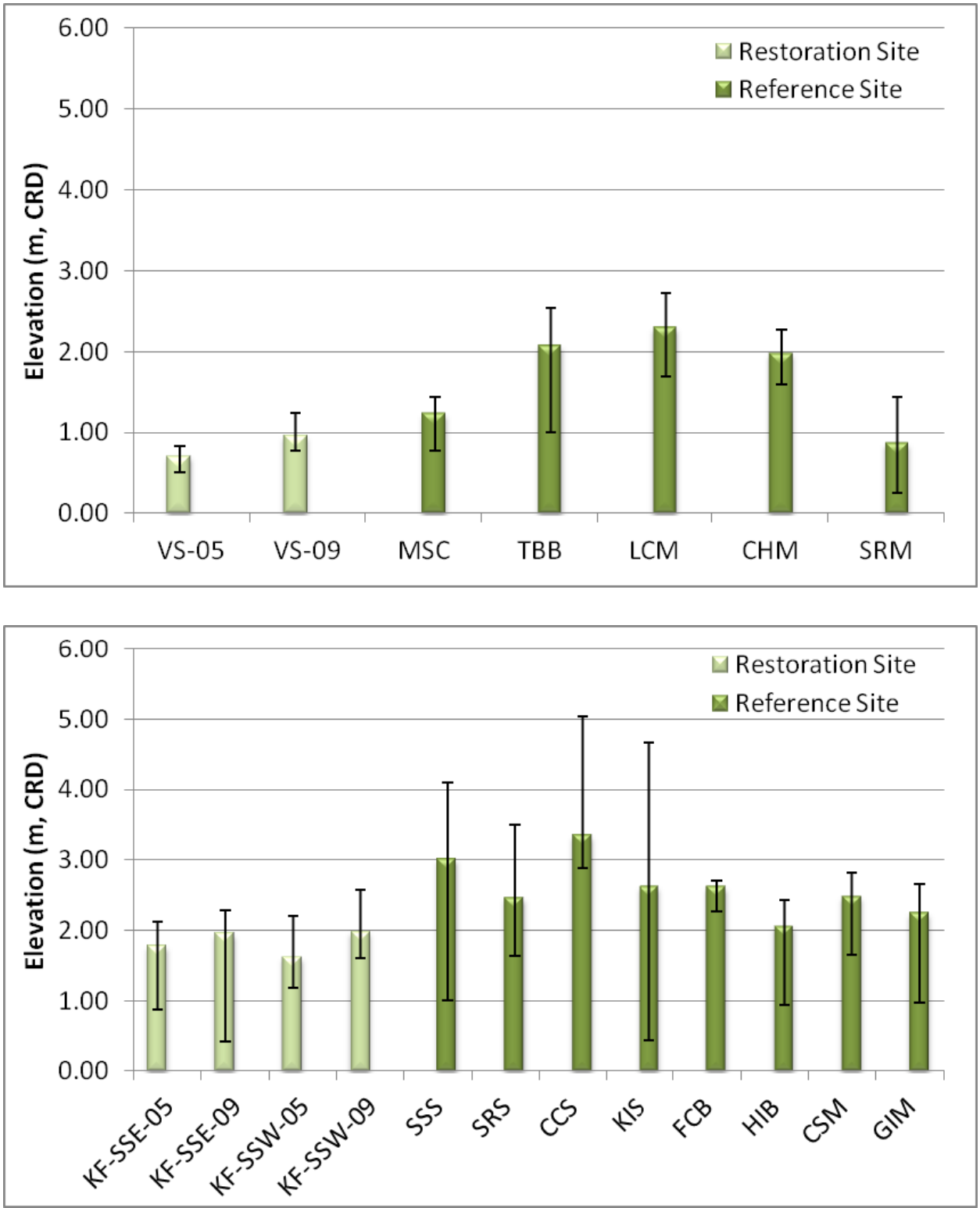

Figure 3.11. Average elevation for the vegetation sample area at restoration sites a) Vera Slough, b) Kandoll Farm, and c) Crims Island compared to the average elevation of the reference site sample areas in each hydro-vegetation zone. Error bars represent the minimum and maximum elevations at the sample area. 


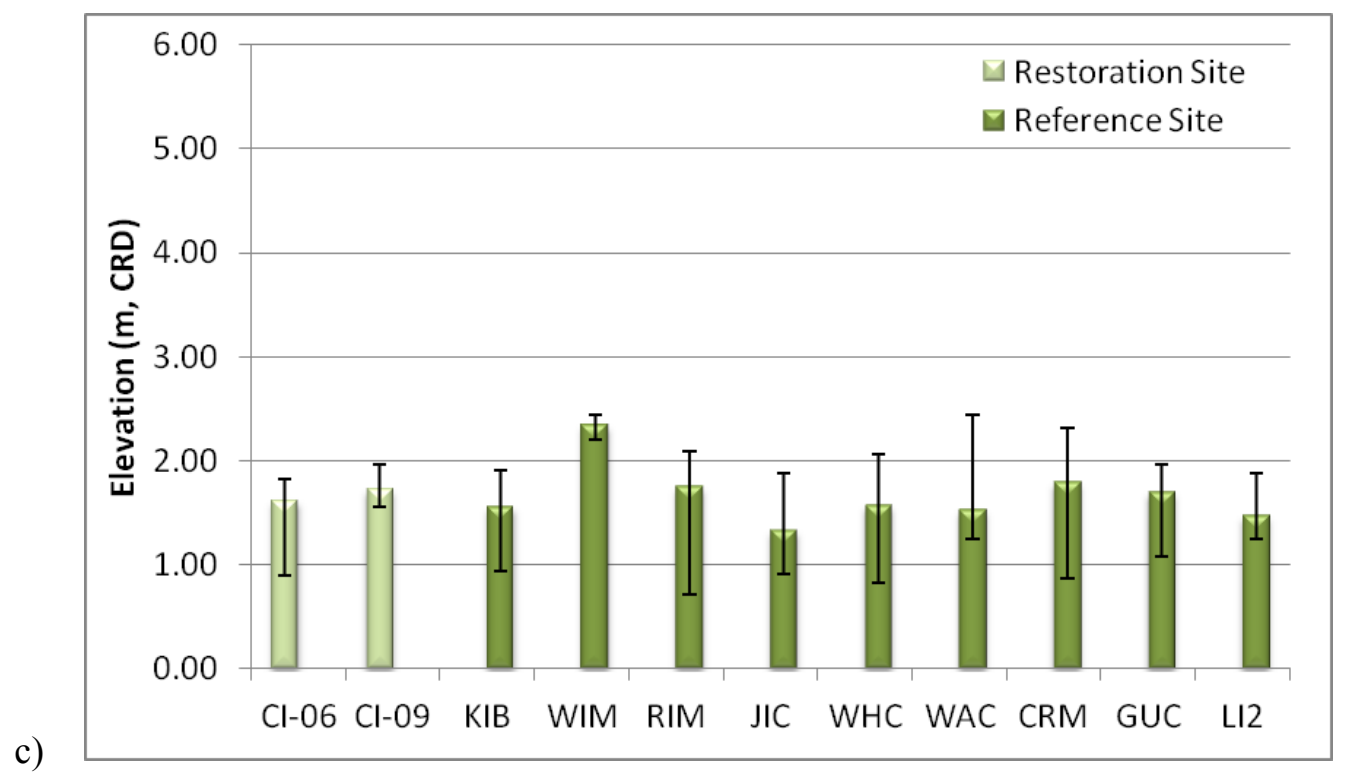

Figure 3.11. (contd)

The greater elevation range at KF in 2009 and the opposite trend at CI could be attributable to the different restoration actions taken at these sites. The topography at KF is likely becoming more channelized over time because the daily tidal flows are re-establishing the dendritic channel patterns that were lost from many years of agricultural practices at the site (see Diefenderfer et al. 2008). In contrast, CI was excavated from a wet pasture, with created channels. The first year after restoration (2006), remnant hummocks and swales were observed from the heavy equipment that evened out by 2009. Small channel development was noted at the site (Borde et al. 2008b); however, it was not in the area of the vegetation sampling.

\subsubsection{Hydrology}

Kandoll Farm SEV was variable between years; however, the range was within that of the marsh reference sites. When compared to the forested reference sites, the SEV at the restoration site is generally higher than at the reference sites. Again, variability between years is evident, with the restoration site having the lowest SEV in 2006-2007. Within the same year, some comparisons can be made between the sites. In 2007-2008, the KF restoration site had the highest SEV and the other three reference sites with data from that year were lower. The CI restoration site had SEVs similar to the reference sites within the same hydro-vegetation zone. 

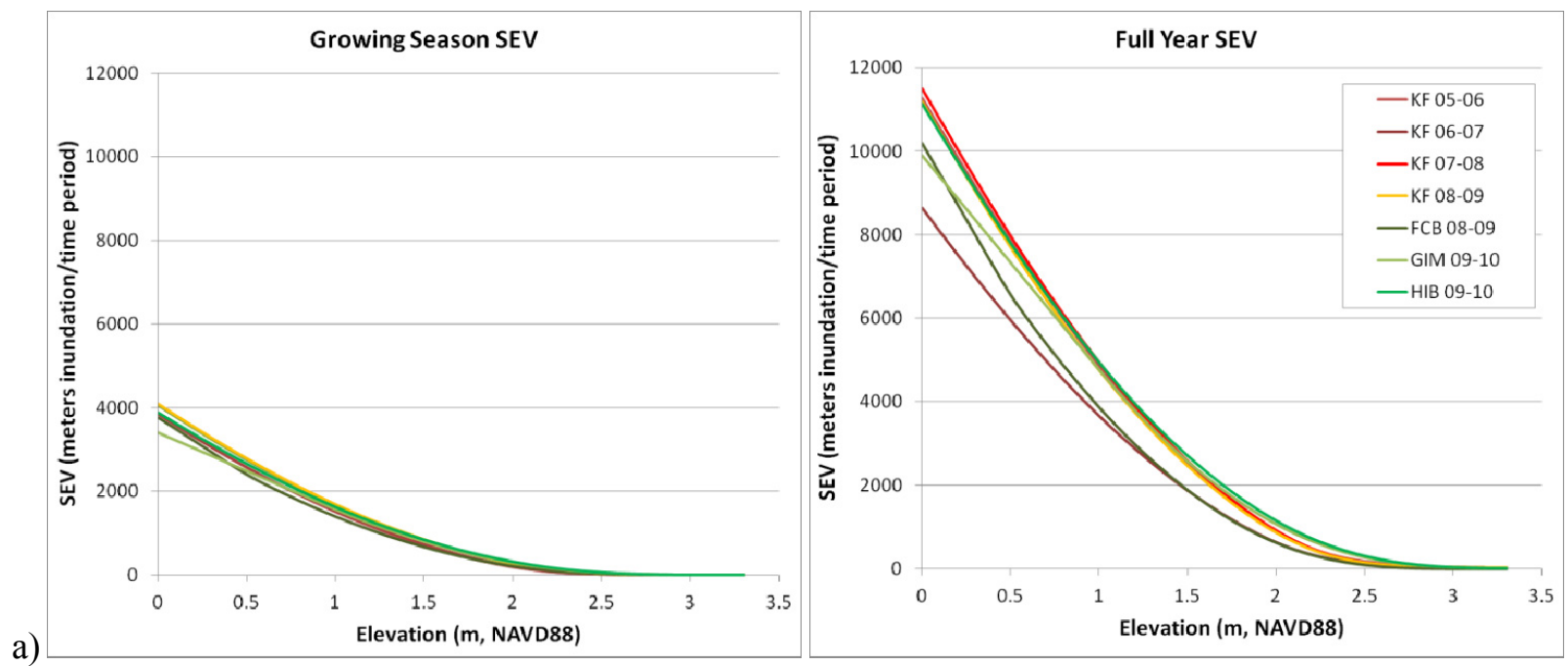

a)
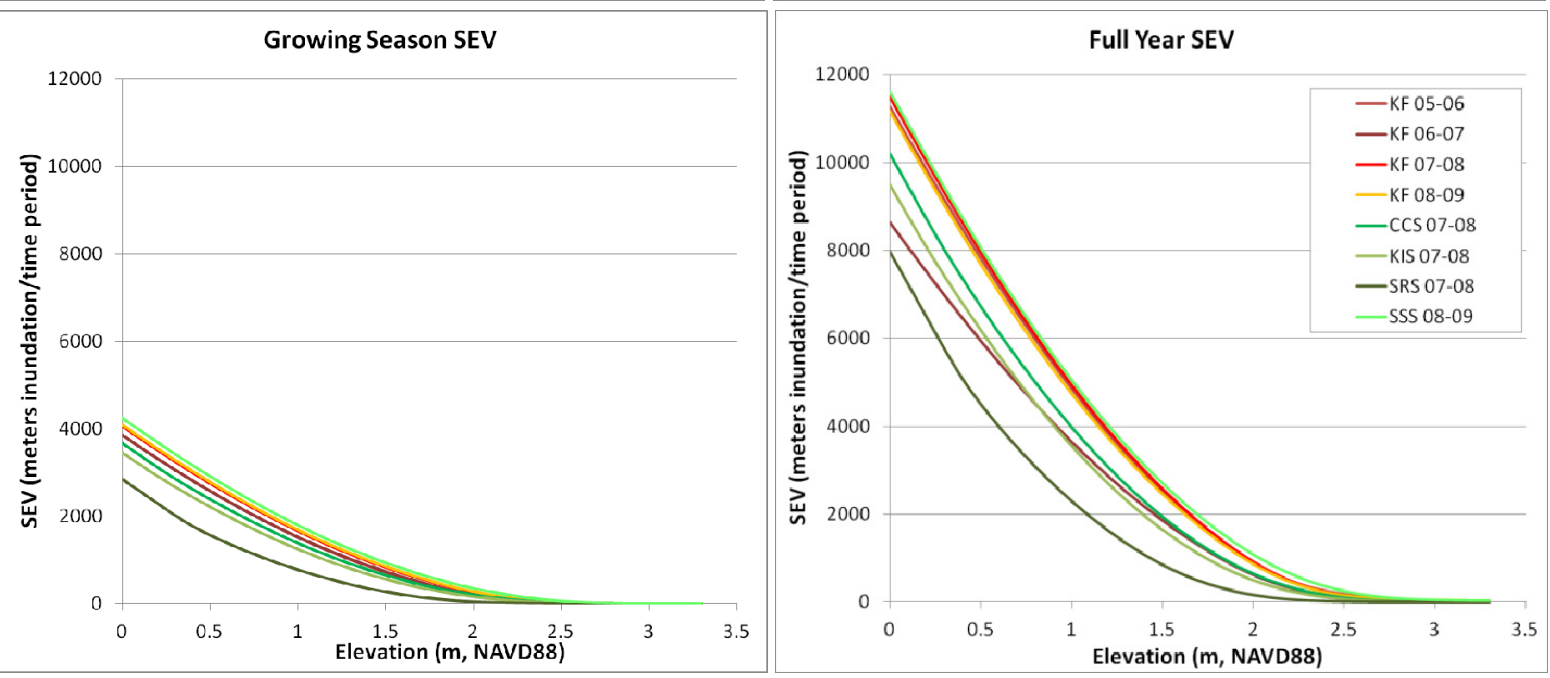

b)
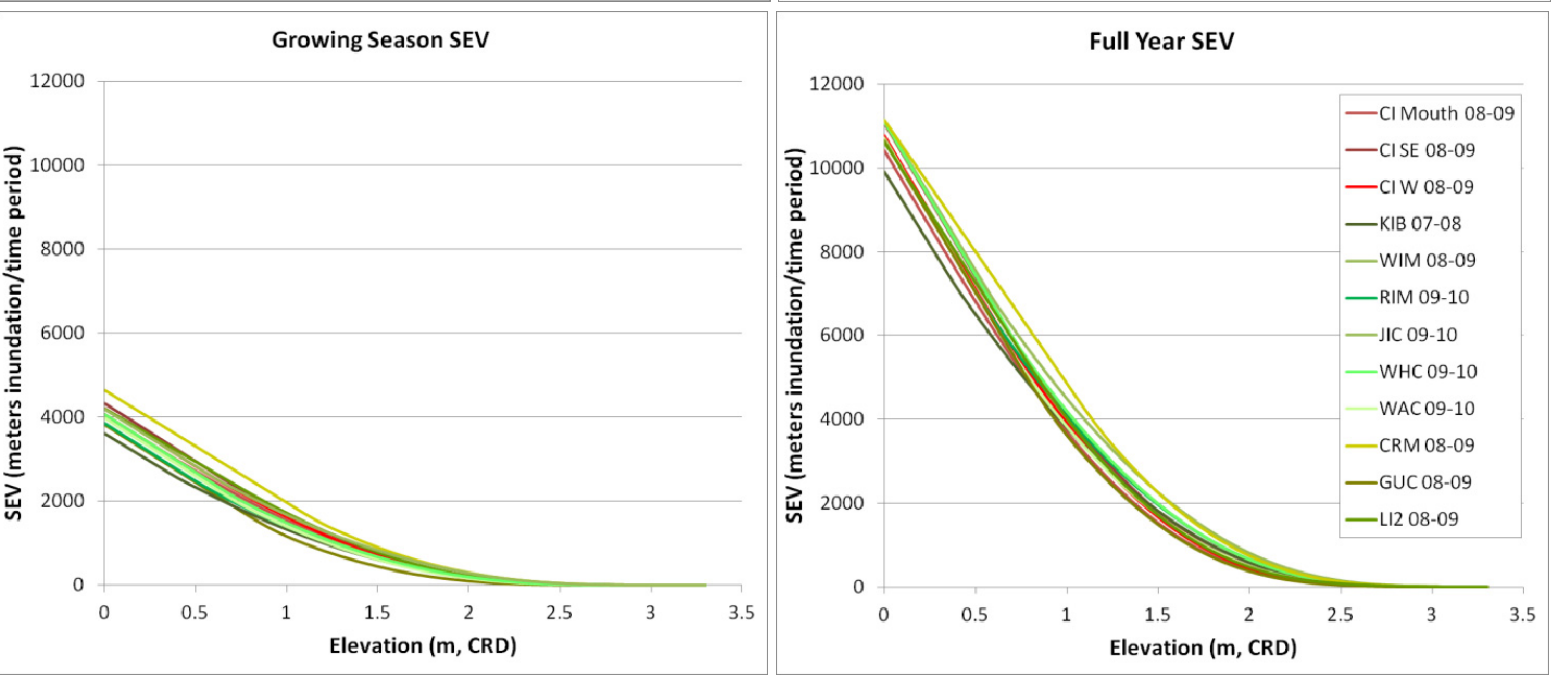

Figure 3.12. Sum exceedance value (SEV) as calculated for the growing season and for a full year at a) Kandoll Farm compared to the tributary marsh reference sites in hydro-vegetation zone 1; b) Kandoll Farm compared to forested wetland reference sites in hydro-vegetation zone 1; and c) Crims Island compared to the marsh reference sites in hydro-vegetation zone 2. 


\subsubsection{Temperature}

In most locations, the water temperature at the reference sites and restoration sites followed similar patterns during the period of peak juvenile Chinook migration from March through July (see Appendix A for graphs showing the temperature patterns during this time period). The seven-day running average of the daily maximum (7DADmax) is one way to evaluate high-temperature patterns and to determine the potential detrimental effect of prolonged high temperature on salmonids. The WADOE has established a criterion of $17.5^{\circ} \mathrm{C}$ as the highest 7DADmax for favorable rearing and migration conditions. Of the 25 reference sites, all of them exceeded the WADOE thermal criterion sometime from May through July. Similarly, all of the of restoration sites exceeded the WADOE thermal criterion from May through July except a couple sensors located in perennial creeks at the Mirror Lake site.

The date of first exceedance of this criterion is a means of estimating the time at which site temperatures may become unfavorable (Table 3.6-Twelve sensors were deployed at the Mirror Lake (ML) site: along the wetland channel and in the two creeks feeding into the wetland (Error! Not a valid bookmark self-reference.). For comparison, at this site we used data from the CR main channel at Camas in addition to the single appropriate reference site. The temperature in the ML creeks stayed below the WADOE criterion throughout the summer in 2010 while most of the wetland channels exceeded the criterion by late June. The reference temperatures were found to exceed the criterion 11 days later than the temperatures in the wetland channel at ML, indicating that the wetland channels are warming sooner than the main channel.

We observed in this analysis that in general the tributary sites remain cooler a little longer than sites located on the main stem of the river. In addition, shade at forested sites appeared to decrease temperatures in some cases, though not where the sites were close to the shallow waters of Grays Bay. Deep channels, such as those found at the mouth of the CI restoration site, also produce a later date of the temperature criterion exceedance. Site-specific features such as logs may also have reduced temperatures at the location of some sensors (e.g., Whites Island, WHC), indicating that such areas could potentially provide thermal refugia for juvenile salmonids.

Table 3.12). The WADOE temperature criterion was generally exceeded in the reference sites within a few days of when it was exceeded at the restoration sites, with a few exceptions. Tenasillahee (TI) was very similar to the Karlson Island previously diked site (KIB) in 2008 (Table 3.9). However, the temperatures were lower than most other reference sites in 2009. The WADOE criterion was exceeded 33 days later at TI in 2009 than the earliest reference site exceedance. The earlier exceedances at the reference sites were from sites located 30-40 km upstream, while the temperature criterion was exceeded only 5 days earlier at the Welch Island reference site (WIM) located a few river kilometers downstream of TI, so higher temperatures may be associated with location in the river. The cooler temperatures at TI could also perhaps be due to the location of the temperature sensor in a deeper channel than those at the reference sites. Ennis (2009) does not give channel depth at the location of the TI sensor, but the channel in general appears to be larger than the reference channels. See site maps in Appendix $C$ for locations of depth/temperature sensors at the reference sites.

Table 3.6. Date of first WADOE 7-day average maximum temperature exceedance at Vera Slough (VS) and the associated marsh reference sites in hydro-vegetation zone 1.

\begin{tabular}{llll}
\hline Year & rkm & 2008 & 2009 \\
\hline
\end{tabular}




\begin{tabular}{llcc}
\hline VS & 19 & ND & 13 May \\
CHM & 12 & ND & 29 April \\
SRM & 37 & 13 May & ND \\
\hline
\end{tabular}

Table 3.7. Date of first WADOE 7-day average maximum temperature exceedance at Kandoll Farm (KF) and Fort Clatsop (FC) restoration sites and the associated marsh tributary reference sites in hydro-vegetation zone 1.

\begin{tabular}{|c|c|c|c|c|c|c|}
\hline Site & $\mathrm{rkm}$ & 2006 & 2007 & 2008 & 2009 & 2010 \\
\hline$\overline{F C}$ & $19^{(\mathrm{a})}$ & & & 15 May & & \\
\hline $\mathrm{KF}$ & $37^{(\mathrm{a})}$ & 15 May & 31 Мay & 26 June & 29 Мау & ND \\
\hline FCB & $19^{(\mathrm{a})}$ & & & & 17 May & \\
\hline GIM & $23^{(a)}$ & & & & & 23 June \\
\hline HIB & $23^{(a)}$ & & & & & 23 June \\
\hline WAB & $23^{(a)}$ & & & & 15 May & \\
\hline WAM & $23^{(a)}$ & & & & 14 May & \\
\hline
\end{tabular}

(a) These sites are located up tributaries. In these cases, the distance from the Columbia River mouth represents the distance to the mouth of the tributary, not the distance up the tributary

Table 3.8. Date of first WADOE 7-day average maximum temperature exceedance at Kandoll Farm (KF) and Fort Clatsop (FC) restoration sites and the associated forested reference sites in hydro-vegetation zone 1.

\begin{tabular}{cccccc}
\hline Site & rkm & 2006 & 2007 & 2008 & 2009 \\
\hline FC & $19^{(\text {a) }}$ & & & 15 May & \\
KF & $37^{(\text {a) }}$ & 15 May & 31 May & 26 June & 29 May \\
\hline SSS & $37^{(\text {a) }}$ & & 27 June & 31 May \\
CCS & $37^{(\text {a) }}$ & & 17 May & \\
KIS & 40 & & 23 June & \\
SRS & $37^{(\text {a) }}$ & & 14 May & \\
\hline
\end{tabular}

(a) These sites are located up tributaries. In these cases, the distance from the Columbia River mouth represents the distance to the mouth of the tributary, not the distance up the tributary

Table 3.9. Date of first WADOE 7-day average maximum temperature exceedance at Tenasillahe (TI) and the associated reference sites. Note: TI tide gates were replaced in August 2007.

\begin{tabular}{lccccccc}
\hline Site & EM Zone & rkm & 2006 & 2007 & 2008 & 2009 & 2010 \\
\hline TI & 2 & 57 & 4 May & 11 May & 14 May & 19 May & ND \\
KIB & 2 & 41 & & & 13 May & & \\
WIM & 2 & 53 & & & & 14 May & \\
RIM & 2 & 61 & & & & & 4 May \\
BSM & 2 & 62 & & & & & 24 June \\
WHC & 2 & 72 & & & & 17 April & 5 May \\
WAC & 2 & 77 & & & & 21 April & \\
CRM & 2 & 80 & & & & 1 June & 27 June \\
\hline LI2 & 2 & 100 & & & & & \\
DSC & 2 & 104 & & & & & \\
\hline
\end{tabular}


The HR site had the earliest temperature criterion exceedance of all the restoration or reference sites (Table 3.10). The site is located up a series of backwater sloughs and may therefore have reduced flows and relative to sites closer to the mainstem. However, the CLM reference site is located approximately 6 $\mathrm{km}$ up a slough and while the temperatures exceeded the criterion in early April, the date was weeks later than at the HR site, indicating that some other factor may be causing the higher temperatures at HR.

Table 3.10. Date of first WADOE 7-day average maximum temperature exceedance at Hogan Ranch (HR) and the associated reference sites in hydro-vegetation zone 4.

\begin{tabular}{lccc}
\hline Site & rkm & 2009 & 2010 \\
\hline HR & 146 & 6 April & 17 March \\
SBM & 143 & & 11 May \\
CS1 & 149 & 14 May & 6 May \\
CLM & 145 & & 12 April \\
SSC & 154 & & 8 April \\
\hline
\end{tabular}

Two sites had multiple sensors deployed where differences were observed within the site. Four sensors were deployed at the restoration site at Crims Island, three in upper portions of the excavated channels and one near the mouth of the main channel (Table 3.11). The sensor at the mouth remained below the WADOE criterion longer than the other three in 2008 by 6 to 8 days, likely because it was placed deeper than the other sensors. In 2009, the temperature at the mouth was similar to that on the west side channel, and both remained below the criterion for 15 days longer than the temperature in the southeast side channel (the northeast side channel sensor was removed in 2009).

Table 3.11. Date of first WADOE 7-day average maximum temperature exceedance at Crims Island (CI) restoration site and the associated reference sites in hydro-vegetation zone 2.

\begin{tabular}{lcccc}
\hline Site & rkm & 2008 & 2009 & 2010 \\
\hline CI-M & \multicolumn{5}{c}{ 24 June } & 29 May & ND \\
CI-WC & 90 & $\begin{array}{c}\text { 14 May } \\
\text { 15 May } \\
\text { CI-SE }\end{array}$ & $\begin{array}{c}\text { 28 May } \\
\text { 19 April }{ }^{(\text {b) }}\end{array}$ & ND \\
CI-NE & \multicolumn{5}{c}{ ND } \\
KIB & 41 & 13 May & ND \\
WIM & 53 & & 14 May \\
RIM & 61 & & 4 May \\
BSM & 62 & & 24 June \\
WHC & 72 & & 20 June \\
WAC & 77 & & 5 May \\
CRM & 80 & & 17 April \\
LI2 & 100 & & 21 April \\
DSC & 104 & June & 27 June \\
\hline
\end{tabular}

(a) Exceeded for one day on 28 April, then not again until 13 May.

(b) Exceeded for two days on 19 April, then not again until 14 May. 
Twelve sensors were deployed at the Mirror Lake (ML) site: along the wetland channel and in the two creeks feeding into the wetland (Error! Not a valid bookmark self-reference.). For comparison, at this site we used data from the CR main channel at Camas in addition to the single appropriate reference site. The temperature in the ML creeks stayed below the WADOE criterion throughout the summer in 2010 while most of the wetland channels exceeded the criterion by late June. The reference temperatures were found to exceed the criterion 11 days later than the temperatures in the wetland channel at ML, indicating that the wetland channels are warming sooner than the main channel.

We observed in this analysis that in general the tributary sites remain cooler a little longer than sites located on the main stem of the river. In addition, shade at forested sites appeared to decrease temperatures in some cases, though not where the sites were close to the shallow waters of Grays Bay. Deep channels, such as those found at the mouth of the CI restoration site, also produce a later date of the temperature criterion exceedance. Site-specific features such as logs may also have reduced temperatures at the location of some sensors (e.g., Whites Island, WHC), indicating that such areas could potentially provide thermal refugia for juvenile salmonids.

Table 3.12. Date of first WADOE 7-day average maximum temperature exceedance at Mirror Lake (ML) restoration site and the associated reference sites in hydro-vegetation zone 5.

\begin{tabular}{lcc}
\hline Site & rkm & 2010 \\
\hline LC/YC-M & & ND \\
LC/YC-2 & & 25 June \\
LC/YC-3 & & 24 June \\
LC-LOW & & 24 June \\
LC-MID & 208 & 4 Aug \\
LC-RR & & DNE $^{(a)}$ \\
YC-ML & & 15 May ${ }^{(b)}$ \\
YC-MID & & 6 July \\
YC-B & & DNE \\
YC-RR & & DNE \\
WRM & 195 & 6 July \\
Camas & 195 & 5 July \\
\hline
\end{tabular}

(a) DNE - Did not exceed the temperature criterion during the period of March through July.

(b) Exceeded for 2 days on 15 May then not again until 25 June.

\subsubsection{Vegetation}

\subsubsection{Bivariate Analysis}

In hydro-vegetation zone 1, we compared average percentage cover of Typha spp. to Carex spp for the bivariate analysis. The results indicate that Vera Slough (VS) had higher cover of Typha and Carex compared to the reference sites in the first two years of monitoring, followed by lower cover of both species by 2009 (Figure 3.13a). This trend is likely due the increase in salinity and inundation following the restoration action resulting in a decrease in the freshwater species of sedge (Carex obnupta) and an 
overall decline in vegetation cover. At the tributary sites in hydro-vegetation zone 1, the results show that Typha does not have high cover at any of the restoration or reference sites. However, Carex was present at a cover of at least $10 \%$ to $50 \%$ at the reference sites, while the restoration sites had less than $10 \%$ Carex cover (Figure 3.13b).

We compared the cover of two native species, common spike rush (Eleocharis palustris; ELPA) and wapato (Sagittaria latifolia; SALA), at sites in the tidal freshwater areas of the LCRE. At the two restoration sites, there was lower cover of both species in the earliest years post-restoration than at most of the reference sites (Figure 3.14). However, both sites trended toward higher cover of the native species in the following monitoring years. The exception is at the HR site where cover of the two species increased in 2008, perhaps due to higher water levels that year, then declined again in 2010.

a)
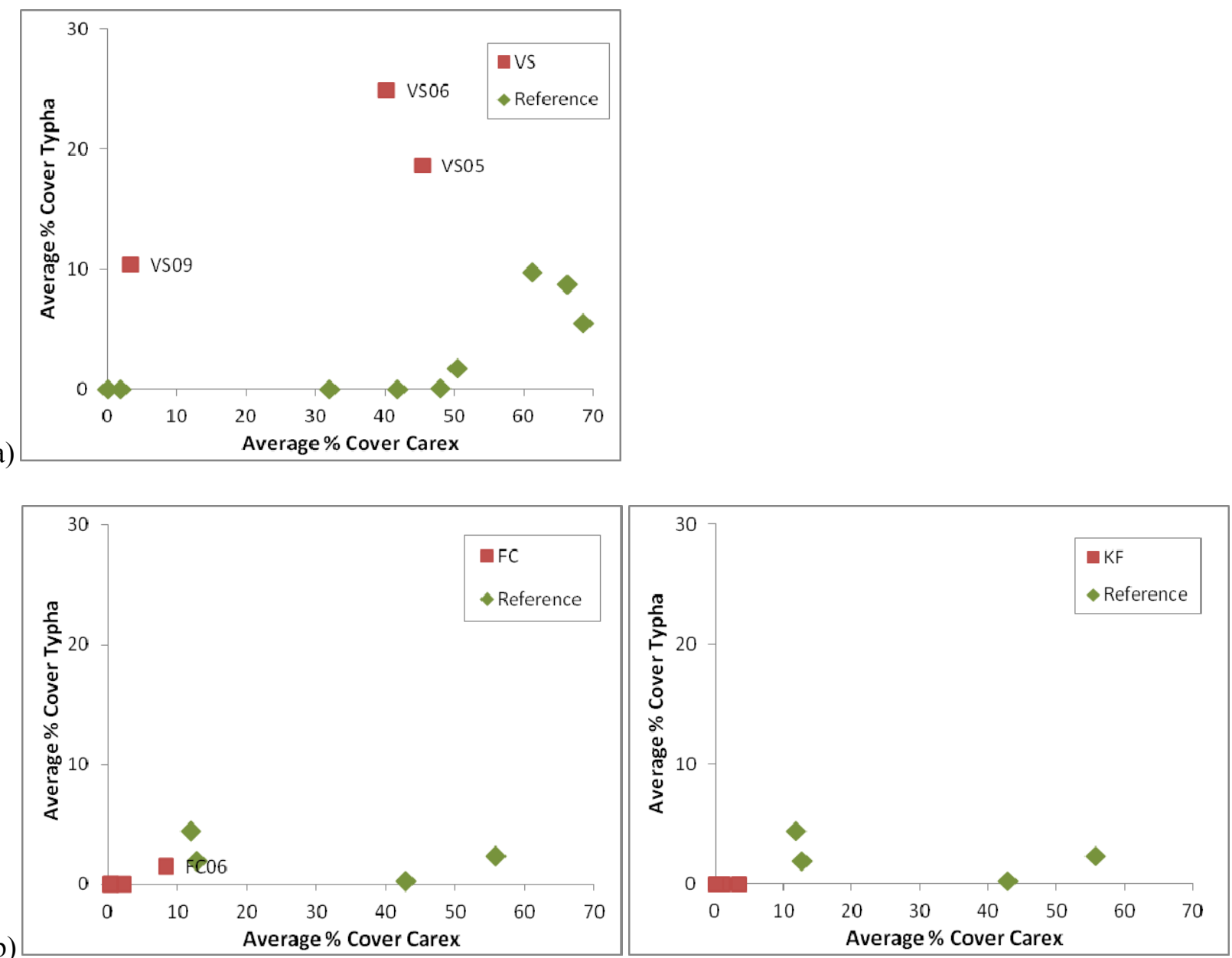

Figure 3.13. Bivariate analysis of average percentage cover of Carex spp. relative to Typha spp. at restoration sites in hydro-vegetation zone 1 compared to reference sites in a) the mainstem and b) tributaries. Each point represents the average cover from 1-year at a site. 

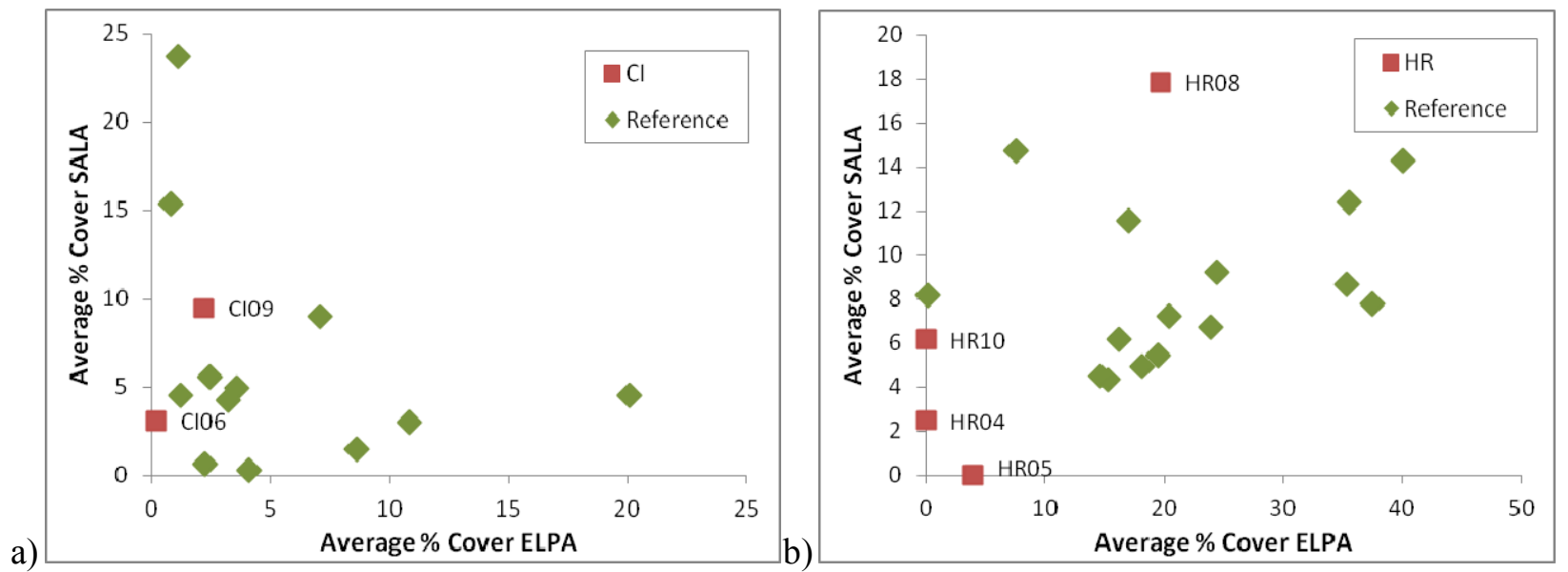

Figure 3.14. Bivariate analysis of average percent cover of Eleocharis palustris (ELPA) relative to Sagittaria latifolia (SALA) at restoration sites compared to reference sites in a) hydrovegetation zone 2 and b) hydro-vegetation zone 4.

\subsubsection{Probability of Occurrence}

The probability of occurrence graphs allow us to look at the change in species occurrence over time at a restoration site and also to compare the restoration site to the probability of occurrence at the reference sites in the same hydro-vegetation zone. In general, the species assemblages at the restoration sites were different from those at the reference sites, particularly in hydro-vegetation zone 1 (Figure 3.15 and Figure 3.16). The vegetation species assemblages at the restoration and reference sites above hydrovegetation zone 1 (and at KF in zone 1, which is above the salinity zone) have a high probability of occurrence of reed canary-grass (Phalaris arundinacea; PHAR) (Figure 3.17 and Figure 3.18). This similarity between the reference and restoration sites is not necessarily desirable because reed canarygrass is a non-native, invasive species. For more information regarding the occurrence and elevations of reed canary-grass, see Borde et al. (2012).

\begin{tabular}{|c|c|c|c|}
\hline \multicolumn{2}{|r|}{ 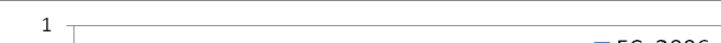 } & \multicolumn{2}{|l|}{1} \\
\hline 0.9 & DFC-2006 & 0.9 & KF - 2005 \\
\hline 0.8 & FC-2008 & 0.8 & KF-2006 \\
\hline 0.7 & $=F C-2009$ & 0.7 & KF -2009 \\
\hline 列 0.6 & a FC-2010 & 0.6 & \\
\hline 0.5 & & 0.5 & \\
\hline 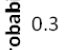 & & 0.3 & \\
\hline $\begin{aligned} 0 \\
0.2 \\
0.1\end{aligned}$ & & 0.2 & 1 \\
\hline & $a_{1}+1$ & & 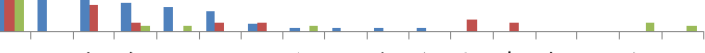 \\
\hline & $5^{2} d\left(x^{2}, v^{2}\right.$ & & 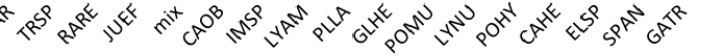 \\
\hline
\end{tabular}




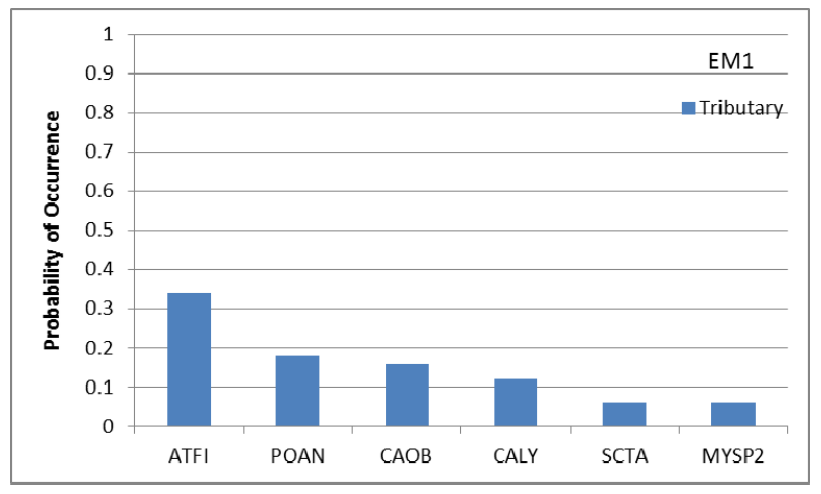

Figure 3.15. The probability of occurrence of plant species at restoration sites Fort Clatsop and Kandoll Farm (top) compared to the probability of occurrence of the dominant species in the leastdisturbed marsh tributary reference sites in hydro-vegetation zone 1 (bottom).
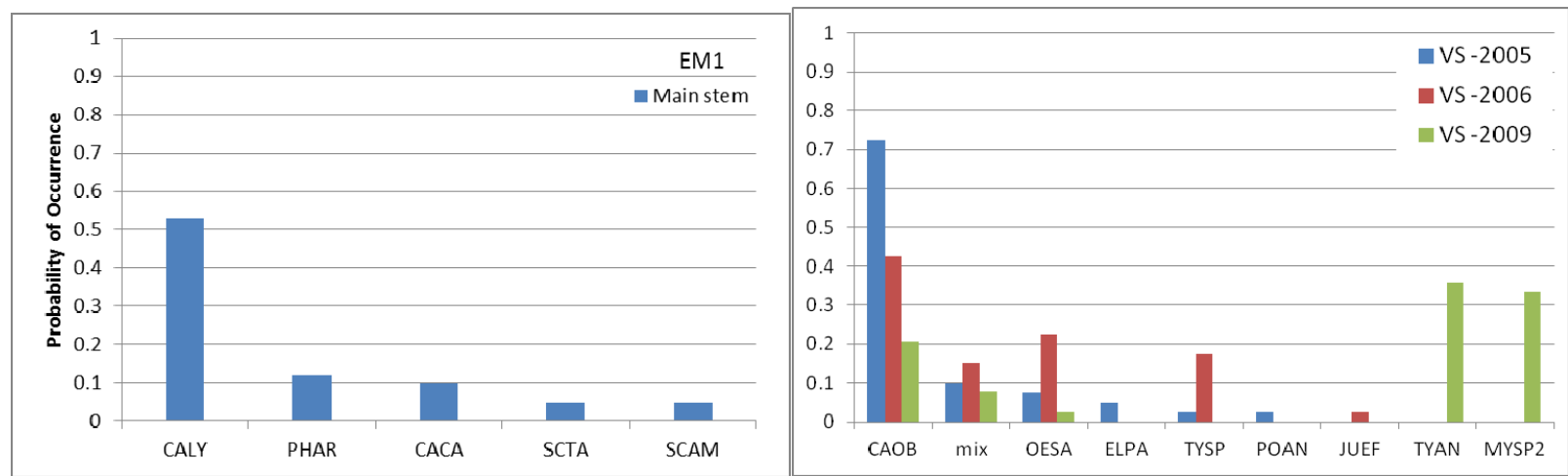

Figure 3.16. The probability of occurrence of plant species at restoration sites Vera Slough (right) compared to the probability of occurrence of the dominant species in the least-disturbed marsh mainstem reference sites in hydro-vegetation zone 1 (left).
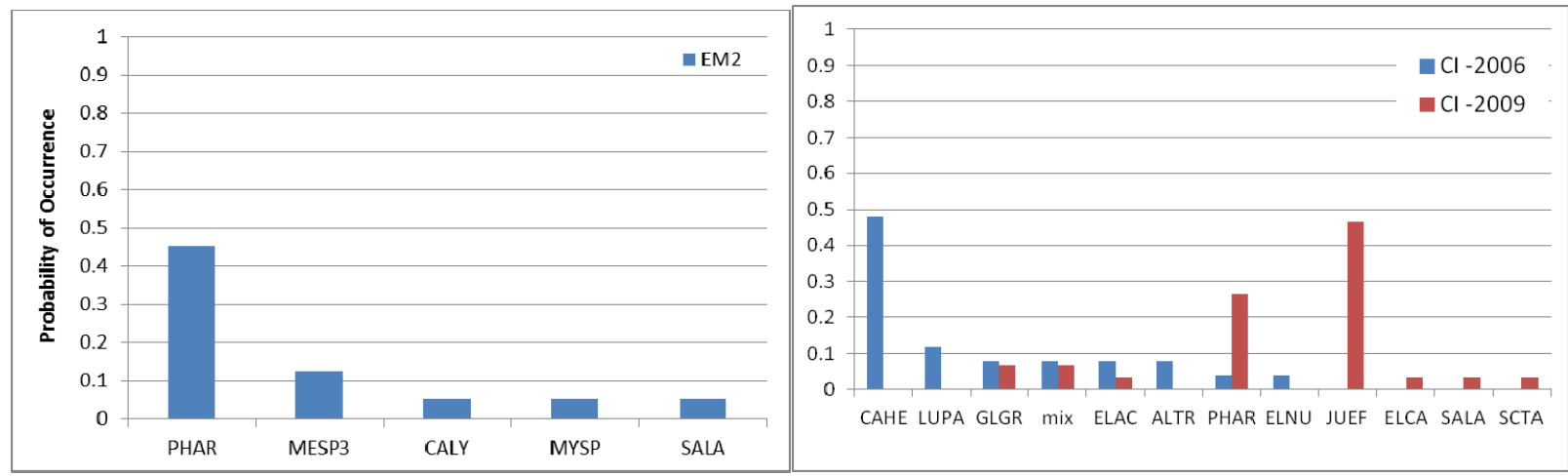

Figure 3.17. The probability of occurrence of plant species at restoration site Crims Island compared to the probability of occurrence of the dominant species in the least-disturbed marsh reference sites in hydro-vegetation zone 2. 


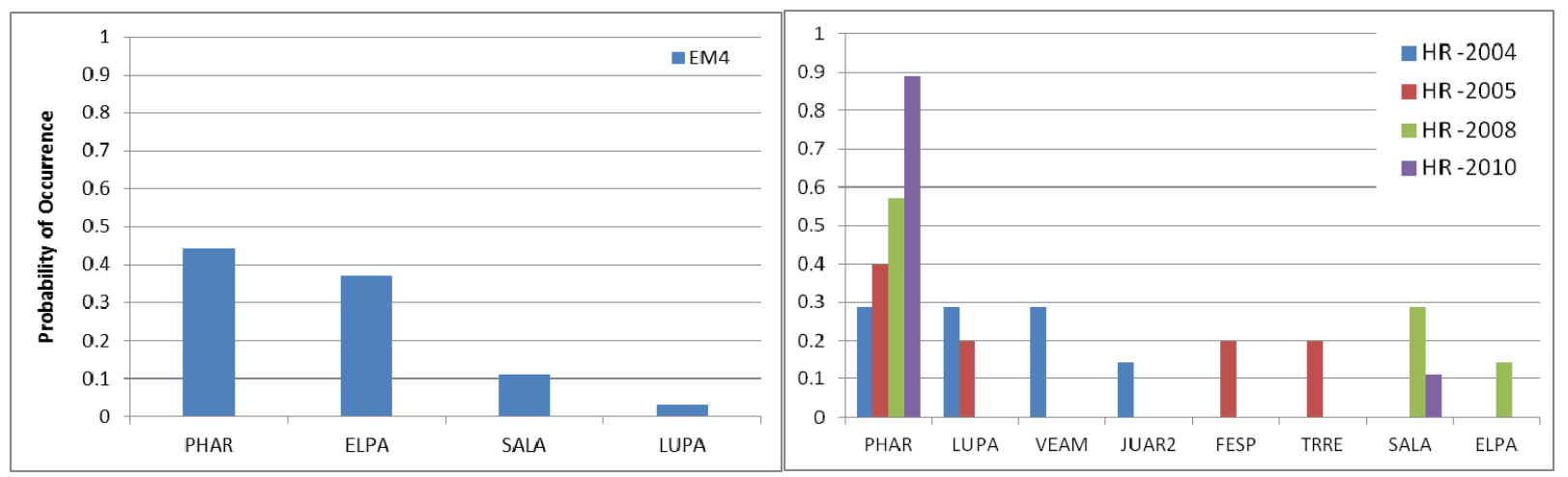

Figure 3.18. The probability of occurrence of plant species at restoration site Hogan Ranch compared to the probability of occurrence of the dominant species in the least-disturbed marsh reference sites in hydro-vegetation zone 4.

\subsubsection{Similarity Index}

The similarity index is a means of comparing the vegetation species composition and cover between sites or between years. In general, we found that most of the vegetation species assemblages at the restoration sites were less than 50\% similar to those found at the reference sites (Table 3.13 through Table 3.16, Table 3.18, and Table 3.20). Exceptions include Hogan Ranch (HR), where the site was greater than $50 \%$ similar to many of the reference sites in most years and greater than $75 \%$ similar in 2008 (Table 3.17). Likewise the sites that were planted with tree and shrub species, Mirror Lake (ML) and the Sandy River Delta (SRD), had species assemblages that were more than $50 \%$ similar to the reference sites for the tree species (Table 3.19 and Table 3.21); however, this represents trees with similar stem density and does not account for the maturity of trees at reference sites compared to plantings.

A comparison between years at restoration sites shows there to be a decreasing similarity in the vegetation species assemblages over time. This trend indicates that each assemblage was changing from initial samplings, which is the expected outcome port-restoration. The further expectation would be that the restoration sites would eventually trend toward a greater similarity to the reference sites, but this can take many years (Thom et al. 2002).

An assessment of the vegetation similarity between multiple years at reference sites indicates that inter-annual variability occurs at these sites. At Cunningham Lake, the similarity between years ranged from $63 \%$ to $84 \%$. Likewise, at Campbell Slough the range was between $73 \%$ and $91 \%$. Presumably, this variability is associated with the hydrologic variability noted earlier; however, local disturbances can have an effect as well. For example, cows inadvertently gained access to the Campbell Slough site in 2007, and the similarity to other years dropped to $65 \%$. In another study, Thom et al. (2002) found that the similarity between years in a reference site ranged from $59 \%$ to $84 \%$. This natural variability at reference sites is important to consider when evaluating restoration trends.

One additional factor that became evident during this analysis is the low similarity of vegetation species assemblages between some of the reference sites within the same hydro-vegetation zone. In hydro-vegetation zone 2 , the high species diversity may provide one explanation for the low similarity between sites (Table 3.16). Another possible explanation for dissimilarity between sites could be disturbances affecting the reference sites. We hypothesize that sites with higher levels of disturbance are 
less similar to other reference sites in the same hydro-vegetation zone. For example, in hydro-vegetation zone 4, the dissimilarity of WRC to all other reference sites could likely be explained by the location of the site in an urban setting and the reduced connectivity to the river due to sediment transport of dredged material across the mouth of the site (Table 3.17). Further assessment of historical and recent disturbances at the sites would help to prove or disprove this hypothesis. 
Table 3.13. Similarity of the herbaceous strata between the restoration sites Kandoll Farm and Fort Clatsop and tributary emergent marsh reference sites in hydro-vegetation zone 1. Numbers after the site codes represent the year of sampling (e.g., $6=2006$ ). Restoration sites are highlighted in yellow. Similarity values greater than $50 \%$ are highlighted in light yellow and greater than $75 \%$ are highlighted in green.

\begin{tabular}{lccccccccccc}
\hline & CSM7 & FCB8 & GIM9 & HIB9 & KF5 & KF6 & KF9 & FC6 & FC8 & FC9 & FC10 \\
\hline CSM7 & 1.00 & 0.23 & 0.11 & 0.10 & 0.06 & 0.06 & 0.03 & 0.26 & 0.06 & 0.08 & 0.01 \\
FCB8 & 0.23 & 1.00 & 0.23 & 0.26 & 0.23 & 0.19 & 0.19 & 0.26 & 0.25 & 0.24 & 0.20 \\
GIM9 & 0.11 & 0.23 & 1.00 & 0.30 & 0.01 & 0.01 & 0.03 & 0.10 & 0.02 & 0.06 & 0.03 \\
HIB9 & 0.10 & 0.26 & 0.30 & 1.00 & 0.18 & 0.19 & 0.20 & 0.22 & 0.24 & 0.21 & 0.28 \\
KF5 & 0.06 & 0.23 & 0.01 & 0.18 & 1.00 & 0.55 & 0.42 & 0.29 & 0.49 & 0.47 & 0.28 \\
KF6 & 0.06 & 0.19 & 0.01 & 0.19 & 0.55 & 1.00 & 0.75 & 0.19 & 0.38 & 0.34 & 0.23 \\
KF9 & 0.03 & 0.19 & 0.03 & 0.20 & 0.42 & 0.75 & 1.00 & 0.09 & 0.27 & 0.24 & 0.18 \\
FC6 & 0.26 & 0.26 & 0.10 & 0.22 & 0.29 & 0.19 & 0.09 & 1.00 & 0.53 & 0.46 & 0.42 \\
FC8 & 0.06 & 0.25 & 0.02 & 0.24 & 0.49 & 0.38 & 0.27 & 0.53 & 1.00 & 0.74 & 0.60 \\
FC9 & 0.08 & 0.24 & 0.06 & 0.21 & 0.47 & 0.34 & 0.24 & 0.46 & 0.74 & 1.00 & 0.65 \\
FC10 & 0.01 & 0.20 & 0.03 & 0.28 & 0.28 & 0.23 & 0.18 & 0.42 & 0.60 & 0.65 & 1.00 \\
\hline
\end{tabular}
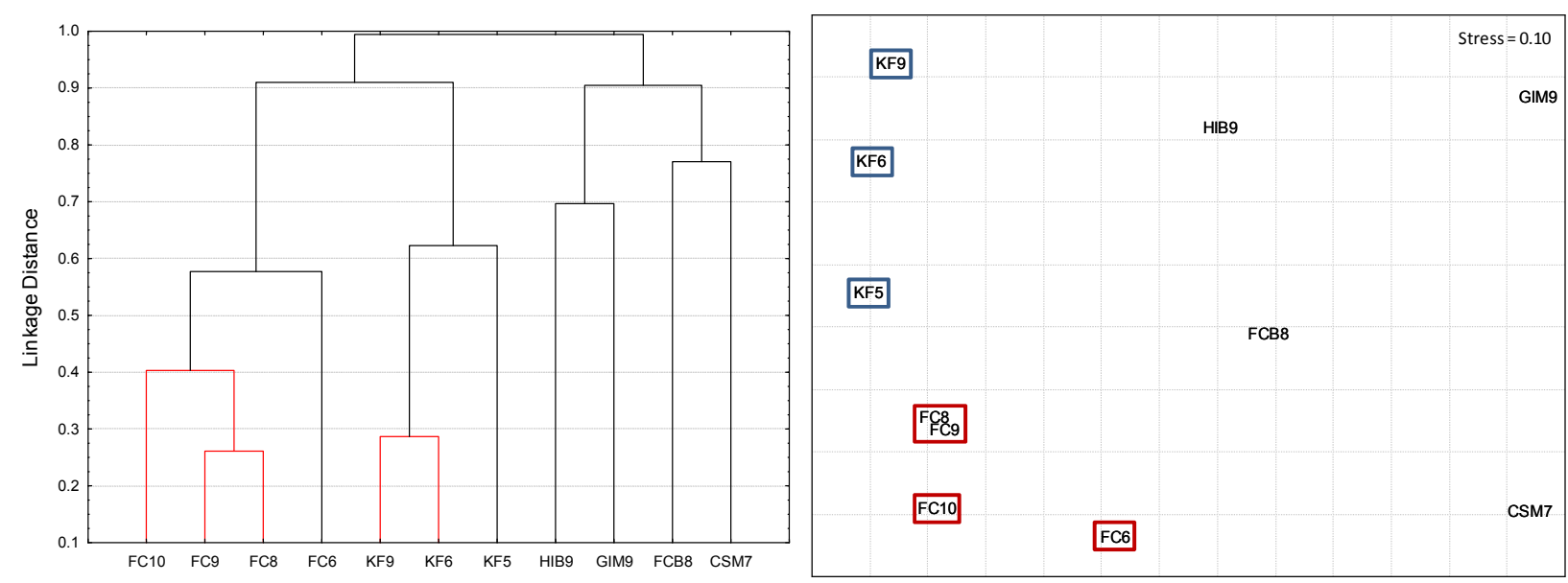

Figure 3.19. Dendrogram (left) and an nMDS plot (right) of the similarity between the restoration sites Fort Clatsop (red boxes) and Kandoll Farm (blue boxes) relative to tributary emergent marsh reference sites in hydro-vegetation zone 1 using complete linkage and Relative Sørensen's similarity measurements. Red lines on the dendrogram represent a similarity greater than $50 \%$. Numbers after the site codes represent the year of sampling (e.g., $6=2006$ ). 
Table 3.14. Similarity of the herbaceous strata between the restoration sites Kandoll Farm and Fort Clatsop and forested swamp reference sites in hydro-vegetation zone 1. Numbers after the site codes represent the year of sampling (e.g., $6=2006$ ). Restoration sites are highlighted in yellow. Similarity values greater than $50 \%$ are highlighted in light yellow and greater than $75 \%$ are highlighted in green.

\begin{tabular}{lccccccccccc}
\hline & CCS7 & KIS8 & SRS8 & SSS9 & KF5 & KF6 & KF9 & FC6 & FC8 & FC9 & FC10 \\
\hline CCS7 & 1.00 & 0.47 & 0.63 & 0.51 & 0.17 & 0.16 & 0.16 & 0.14 & 0.10 & 0.07 & 0.06 \\
KIS8 & 0.47 & 1.00 & 0.30 & 0.38 & 0.08 & 0.05 & 0.09 & 0.04 & 0.01 & 0.03 & 0.03 \\
SRS8 & 0.63 & 0.30 & 1.00 & 0.44 & 0.18 & 0.18 & 0.19 & 0.09 & 0.14 & 0.12 & 0.11 \\
SS59 & 0.51 & 0.38 & 0.44 & 1.00 & 0.23 & 0.20 & 0.20 & 0.19 & 0.15 & 0.13 & 0.12 \\
KF5 & 0.17 & 0.08 & 0.18 & 0.23 & 1.00 & 0.55 & 0.42 & 0.31 & 0.51 & 0.48 & 0.30 \\
KF6 & 0.16 & 0.05 & 0.18 & 0.20 & 0.55 & 1.00 & 0.75 & 0.20 & 0.39 & 0.35 & 0.23 \\
KF9 & 0.16 & 0.09 & 0.19 & 0.20 & 0.42 & 0.75 & 1.00 & 0.09 & 0.27 & 0.24 & 0.19 \\
FC6 & 0.14 & 0.04 & 0.09 & 0.19 & 0.31 & 0.20 & 0.09 & 1.00 & 0.53 & 0.46 & 0.42 \\
FC8 & 0.10 & 0.01 & 0.14 & 0.15 & 0.51 & 0.39 & 0.27 & 0.53 & 1.00 & 0.74 & 0.60 \\
FC9 & 0.07 & 0.03 & 0.12 & 0.13 & 0.48 & 0.35 & 0.24 & 0.46 & 0.74 & 1.00 & 0.65 \\
FC10 & 0.06 & 0.03 & 0.11 & 0.12 & 0.30 & 0.23 & 0.19 & 0.42 & 0.60 & 0.65 & 1.00 \\
\hline
\end{tabular}
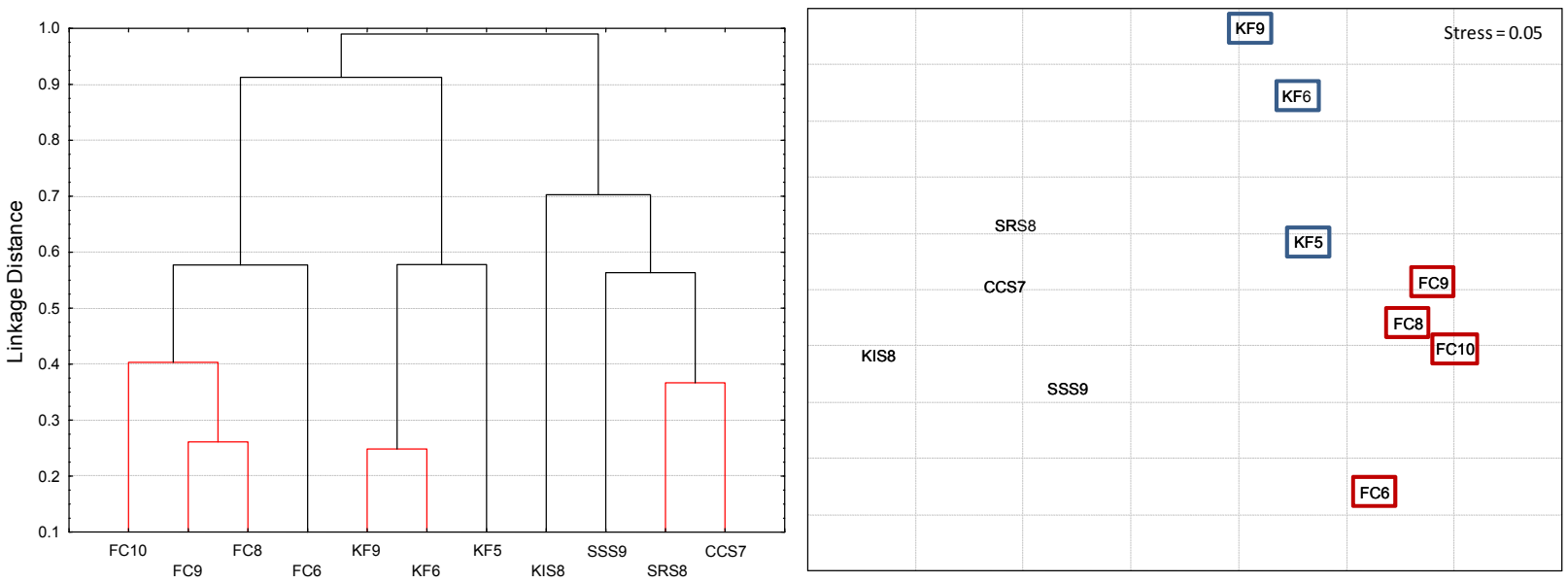

Figure 3.20. Dendrogram (left) and an nMDS plot (right) of the similarity between the restoration sites Kandoll Farm and Fort Clatsop and forested swamp reference sites using complete linkage and relative Sørensen's similarity measurement. Red lines on the dendrogram represent a similarity greater than $50 \%$. Numbers after the site codes represent the year of sampling (e.g., $6=2006$ ). 
Table 3.15. Similarity of the herbaceous strata between the restoration site Vera Slough and mainstem emergent marsh reference sites in hydro-vegetation zone 1 . Numbers after the site codes represent the year of sampling (e.g., $6=2006$ ). Restoration sites are highlighted in yellow and multiple years for a reference site are highlighted in orange. Similarity values greater than $50 \%$ are highlighted in light yellow and greater than $75 \%$ are highlighted in green.

\begin{tabular}{lccccccccccccc}
\hline & CHM-H9 & CHM-L9 & LCM5 & LCM6 & LCM9 & MSC9 & SRM-H8 & SRM-L8 & TBB8 & VS5 & VS6 & VS9 \\
\hline CHM-H9 & 1.00 & 0.64 & 0.31 & 0.32 & 0.31 & 0.15 & 0.33 & 0.11 & 0.56 & 0.01 & 0.00 & 0.00 \\
CHM-L9 & 0.64 & 1.00 & 0.37 & 0.38 & 0.37 & 0.16 & 0.38 & 0.14 & 0.54 & 0.01 & 0.00 & 0.00 \\
LCM5 & 0.31 & 0.37 & 1.00 & 0.90 & 0.85 & 0.00 & 0.62 & 0.11 & 0.59 & 0.19 & 0.16 & 0.05 \\
LCM6 & 0.32 & 0.38 & 0.90 & 1.00 & 0.84 & 0.02 & 0.59 & 0.12 & 0.58 & 0.11 & 0.09 & 0.03 \\
LCM9 & 0.31 & 0.37 & 0.85 & 0.84 & 1.00 & 0.00 & 0.63 & 0.15 & 0.59 & 0.12 & 0.10 & 0.06 \\
MSC9 & 0.15 & 0.16 & 0.00 & 0.02 & 0.00 & 1.00 & 0.01 & 0.13 & 0.01 & 0.02 & 0.00 & 0.00 \\
SRM-H8 & 0.33 & 0.38 & 0.62 & 0.59 & 0.63 & 0.01 & 1.00 & 0.14 & 0.48 & 0.18 & 0.15 & 0.08 \\
SRM-L8 & 0.11 & 0.14 & 0.11 & 0.12 & 0.15 & 0.13 & 0.14 & 1.00 & 0.04 & 0.06 & 0.01 & 0.00 \\
TBB8 & 0.56 & 0.54 & 0.59 & 0.58 & 0.59 & 0.01 & 0.48 & 0.04 & 1.00 & 0.08 & 0.02 & 0.00 \\
VS5 & 0.01 & 0.01 & 0.19 & 0.11 & 0.12 & 0.02 & 0.18 & 0.06 & 0.08 & 1.00 & 0.78 & 0.22 \\
VS6 & 0.00 & 0.00 & 0.16 & 0.09 & 0.10 & 0.00 & 0.15 & 0.01 & 0.02 & 0.78 & 1.00 & 0.22 \\
VS9 & 0.00 & 0.00 & 0.05 & 0.03 & 0.06 & 0.00 & 0.08 & 0.00 & 0.00 & 0.22 & 0.22 & 1.00 \\
\hline
\end{tabular}
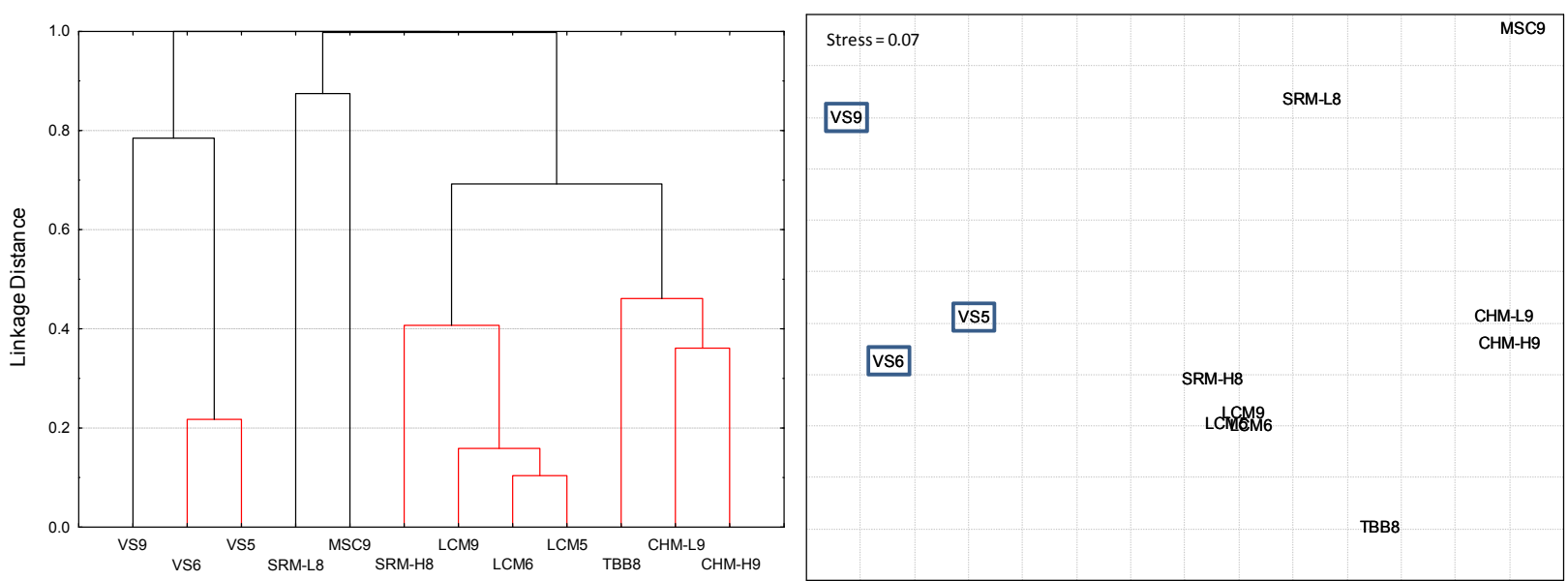

Figure 3.21. Dendrogram (left) and an nMDS plot (right) of the similarity between the restoration site Vera Slough relative to selected reference sites using complete linkage and relative Sørensen's similarity. Red lines on the dendrogram represent a similarity greater than $50 \%$. Numbers after the site codes represent the year of sampling (e.g., $6=2006$ ). 
Table 3.16. Similarity of the herbaceous strata between the restoration site Crims Island and mainstem emergent marsh reference sites in hydro-vegetation zone 2 . Numbers after the site codes represent the year of sampling (e.g., $6=2006$ ). Restoration sites are highlighted in yellow and multiple years for a reference site are highlighted in orange. Similarity values greater than $50 \%$ are highlighted in light yellow and greater than $75 \%$ are highlighted in green.

\begin{tabular}{lccccccccccccccc}
\hline & CRM9 & GUC6 & GUC9 & JIC10 & KIB8 & LI29 & RIM9 & WAC10 & WHC9 & WHC10 & WIM8 & CI6 & CI9 \\
\hline CRM9 & 1.00 & 0.22 & 0.22 & 0.42 & 0.31 & 0.33 & 0.47 & 0.37 & 0.65 & 0.54 & 0.15 & 0.14 & 0.45 \\
GUC6 & 0.22 & 1.00 & 0.52 & 0.20 & 0.33 & 0.16 & 0.11 & 0.12 & 0.21 & 0.09 & 0.18 & 0.11 & 0.12 \\
GUC9 & 0.22 & 0.52 & 1.00 & 0.18 & 0.43 & 0.12 & 0.13 & 0.13 & 0.22 & 0.09 & 0.19 & 0.08 & 0.12 \\
JIC10 & 0.42 & 0.20 & 0.18 & 1.00 & 0.29 & 0.29 & 0.49 & 0.49 & 0.46 & 0.46 & 0.14 & 0.23 & 0.41 \\
KIB8 & 0.31 & 0.33 & 0.43 & 0.29 & 1.00 & 0.20 & 0.23 & 0.22 & 0.34 & 0.24 & 0.19 & 0.13 & 0.24 \\
LI29 & 0.33 & 0.16 & 0.12 & 0.29 & 0.20 & 1.00 & 0.20 & 0.23 & 0.22 & 0.21 & 0.10 & 0.12 & 0.27 \\
RIM9 & 0.47 & 0.11 & 0.13 & 0.49 & 0.23 & 0.20 & 1.00 & 0.36 & 0.60 & 0.54 & 0.16 & 0.09 & 0.33 \\
WAC10 & 0.37 & 0.12 & 0.13 & 0.49 & 0.22 & 0.23 & 0.36 & 1.00 & 0.41 & 0.44 & 0.11 & 0.17 & 0.37 \\
WHC9 & 0.65 & 0.21 & 0.22 & 0.46 & 0.34 & 0.22 & 0.60 & 0.41 & 1.00 & 0.72 & 0.16 & 0.13 & 0.38 \\
WHC10 & 0.54 & 0.09 & 0.09 & 0.46 & 0.24 & 0.21 & 0.54 & 0.44 & 0.72 & 1.00 & 0.22 & 0.16 & 0.38 \\
WIM8 & 0.15 & 0.18 & 0.19 & 0.14 & 0.19 & 0.10 & 0.16 & 0.11 & 0.16 & 0.22 & 1.00 & 0.10 & 0.13 \\
CI6 & 0.14 & 0.11 & 0.08 & 0.23 & 0.13 & 0.12 & 0.09 & 0.17 & 0.13 & 0.16 & 0.10 & 1.00 & 0.30 \\
CI9 & 0.45 & 0.12 & 0.12 & 0.41 & 0.24 & 0.27 & 0.33 & 0.37 & 0.38 & 0.38 & 0.13 & 0.30 & 1.00 \\
\hline
\end{tabular}
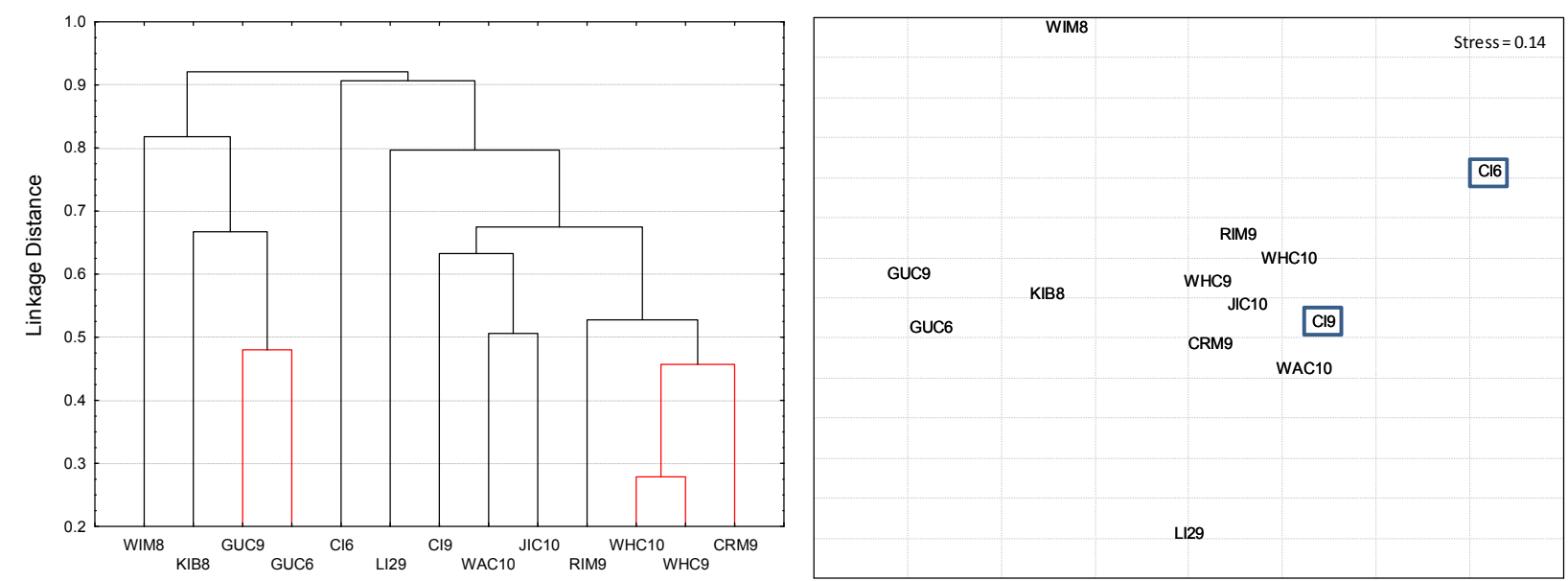

Figure 3.22. Dendrogram (left) and an nMDS plot (right) of the similarity between the restoration site Crims Island relative to mainstem emergent marsh reference sites in hydro-vegetation zone 2 using complete linkage and relative Sørensen's similarity. Red lines on the dendrogram represent a similarity greater than $50 \%$. Numbers after the site codes represent the year of sampling (e.g., $6=2006$ ). 
Table 3.17. Similarity of the herbaceous strata between the restoration site Hogan Ranch and mainstem emergent marsh reference sites in hydrovegetation zone 4 . Numbers after the site codes represent the year of sampling (e.g., $6=2006$ ). Restoration sites are highlighted in yellow and multiple years for a reference site are highlighted in orange. Similarity values greater than $50 \%$ are highlighted in light yellow and greater than $75 \%$ are highlighted in green.

\begin{tabular}{|c|c|c|c|c|c|c|c|c|c|c|c|c|c|c|c|c|c|c|c|c|}
\hline & CLM5 & CLM6 & CLM7 & CLM8 & CLM9 & CLM10 & CS1 5 & CS1 6 & CS1 7 & CS1 8 & CS1 9 & CS1 10 & DMI7 & SBM10 & SSC5 & WRC6 & HR4 & HR5 & HR8 & HR10 \\
\hline CLM5 & 1.00 & 0.84 & 0.77 & 0.77 & 0.82 & 0.72 & 0.79 & 0.85 & 0.66 & 0.77 & 0.88 & 0.89 & 0.49 & 0.68 & 0.78 & 0.36 & 0.32 & 0.48 & 0.77 & 0.51 \\
\hline CLM6 & 0.84 & 1.00 & 0.71 & 0.68 & 0.80 & 0.63 & 0.68 & 0.73 & 0.66 & 0.68 & 0.84 & 0.81 & 0.54 & 0.58 & 0.66 & 0.33 & 0.34 & 0.38 & 0.65 & 0.42 \\
\hline CLM7 & 0.77 & 0.71 & 1.00 & 0.83 & 0.82 & 0.73 & 0.76 & 0.77 & 0.71 & 0.83 & 0.74 & 0.78 & 0.51 & 0.61 & 0.71 & 0.43 & 0.44 & 0.58 & 0.70 & 0.49 \\
\hline CLM8 & 0.77 & 0.68 & 0.83 & 1.00 & 0.79 & 0.79 & 0.84 & 0.81 & 0.68 & 0.89 & 0.74 & 0.78 & 0.52 & 0.69 & 0.78 & 0.34 & 0.34 & 0.55 & 0.79 & 0.57 \\
\hline CLM9 & 0.82 & 0.80 & 0.82 & 0.79 & 1.00 & 0.71 & 0.74 & 0.74 & 0.70 & 0.78 & 0.84 & 0.83 & 0.58 & 0.58 & 0.68 & 0.37 & 0.39 & 0.50 & 0.68 & 0.47 \\
\hline CLM10 & 0.72 & 0.63 & 0.73 & 0.79 & 0.71 & 1.00 & 0.92 & 0.79 & 0.62 & 0.80 & 0.67 & 0.74 & 0.45 & 0.77 & 0.81 & 0.31 & 0.33 & 0.54 & 0.86 & 0.65 \\
\hline CS1 5 & 0.79 & 0.68 & 0.76 & 0.84 & 0.74 & 0.92 & 1.00 & 0.84 & 0.65 & 0.85 & 0.73 & 0.79 & 0.48 & 0.76 & 0.86 & 0.33 & 0.33 & 0.54 & 0.86 & 0.62 \\
\hline CS1 6 & 0.85 & 0.73 & 0.77 & 0.81 & 0.74 & 0.79 & 0.84 & 1.00 & 0.66 & 0.84 & 0.80 & 0.81 & 0.47 & 0.80 & 0.80 & 0.41 & 0.31 & 0.52 & 0.90 & 0.58 \\
\hline CS1 7 & 0.66 & 0.66 & 0.71 & 0.68 & 0.70 & 0.62 & 0.65 & 0.66 & 1.00 & 0.72 & 0.68 & 0.69 & 0.50 & 0.50 & 0.62 & 0.34 & 0.36 & 0.40 & 0.61 & 0.40 \\
\hline CS1 8 & 0.77 & 0.68 & 0.83 & 0.89 & 0.78 & 0.80 & 0.85 & 0.84 & 0.72 & 1.00 & 0.75 & 0.81 & 0.52 & 0.69 & 0.81 & 0.35 & 0.37 & 0.57 & 0.80 & 0.60 \\
\hline CS1 9 & 0.88 & 0.84 & 0.74 & 0.74 & 0.84 & 0.67 & 0.73 & 0.80 & 0.68 & 0.75 & 1.00 & 0.91 & 0.52 & 0.63 & 0.68 & 0.37 & 0.33 & 0.43 & 0.74 & 0.46 \\
\hline CS1 10 & 0.89 & 0.81 & 0.78 & 0.78 & 0.83 & 0.74 & 0.79 & 0.81 & 0.69 & 0.81 & 0.91 & 1.00 & 0.51 & 0.64 & 0.75 & 0.32 & 0.34 & 0.50 & 0.74 & 0.52 \\
\hline DMI7 & 0.49 & 0.54 & 0.51 & 0.52 & 0.58 & 0.45 & 0.48 & 0.47 & 0.50 & 0.52 & 0.52 & 0.51 & 1.00 & 0.32 & 0.46 & 0.24 & 0.26 & 0.27 & 0.42 & 0.22 \\
\hline SBM10 & 0.68 & 0.58 & 0.61 & 0.69 & 0.58 & 0.77 & 0.76 & 0.80 & 0.50 & 0.69 & 0.63 & 0.64 & 0.32 & 1.00 & 0.72 & 0.42 & 0.32 & 0.53 & 0.89 & 0.72 \\
\hline SSC5 & 0.78 & 0.66 & 0.71 & 0.78 & 0.68 & 0.81 & 0.86 & 0.80 & 0.62 & 0.81 & 0.68 & 0.75 & 0.46 & 0.72 & 1.00 & 0.29 & 0.43 & 0.53 & 0.82 & 0.61 \\
\hline WRC6 & 0.36 & 0.33 & 0.43 & 0.34 & 0.37 & 0.31 & 0.33 & 0.41 & 0.34 & 0.35 & 0.37 & 0.32 & 0.24 & 0.42 & 0.29 & 1.00 & 0.40 & 0.35 & 0.41 & 0.29 \\
\hline HR4 & 0.32 & 0.34 & 0.44 & 0.34 & 0.39 & 0.33 & 0.33 & 0.31 & 0.36 & 0.37 & 0.33 & 0.34 & 0.26 & 0.32 & 0.43 & 0.40 & 1.00 & 0.46 & 0.32 & 0.31 \\
\hline HR5 & 0.48 & 0.38 & 0.58 & 0.55 & 0.50 & 0.54 & 0.54 & 0.52 & 0.40 & 0.57 & 0.43 & 0.50 & 0.27 & 0.53 & 0.53 & 0.35 & 0.46 & 1.00 & 0.52 & 0.48 \\
\hline HR8 & 0.77 & 0.65 & 0.70 & 0.79 & 0.68 & 0.86 & 0.86 & 0.90 & 0.61 & 0.80 & 0.74 & 0.74 & 0.42 & 0.89 & 0.82 & 0.41 & 0.32 & 0.52 & 1.00 & 0.67 \\
\hline HR10 & 0.51 & 0.42 & 0.49 & 0.57 & 0.47 & 0.65 & 0.62 & 0.58 & 0.40 & 0.60 & 0.46 & 0.52 & 0.22 & 0.72 & 0.61 & 0.29 & 0.31 & 0.48 & 0.67 & 1.00 \\
\hline
\end{tabular}



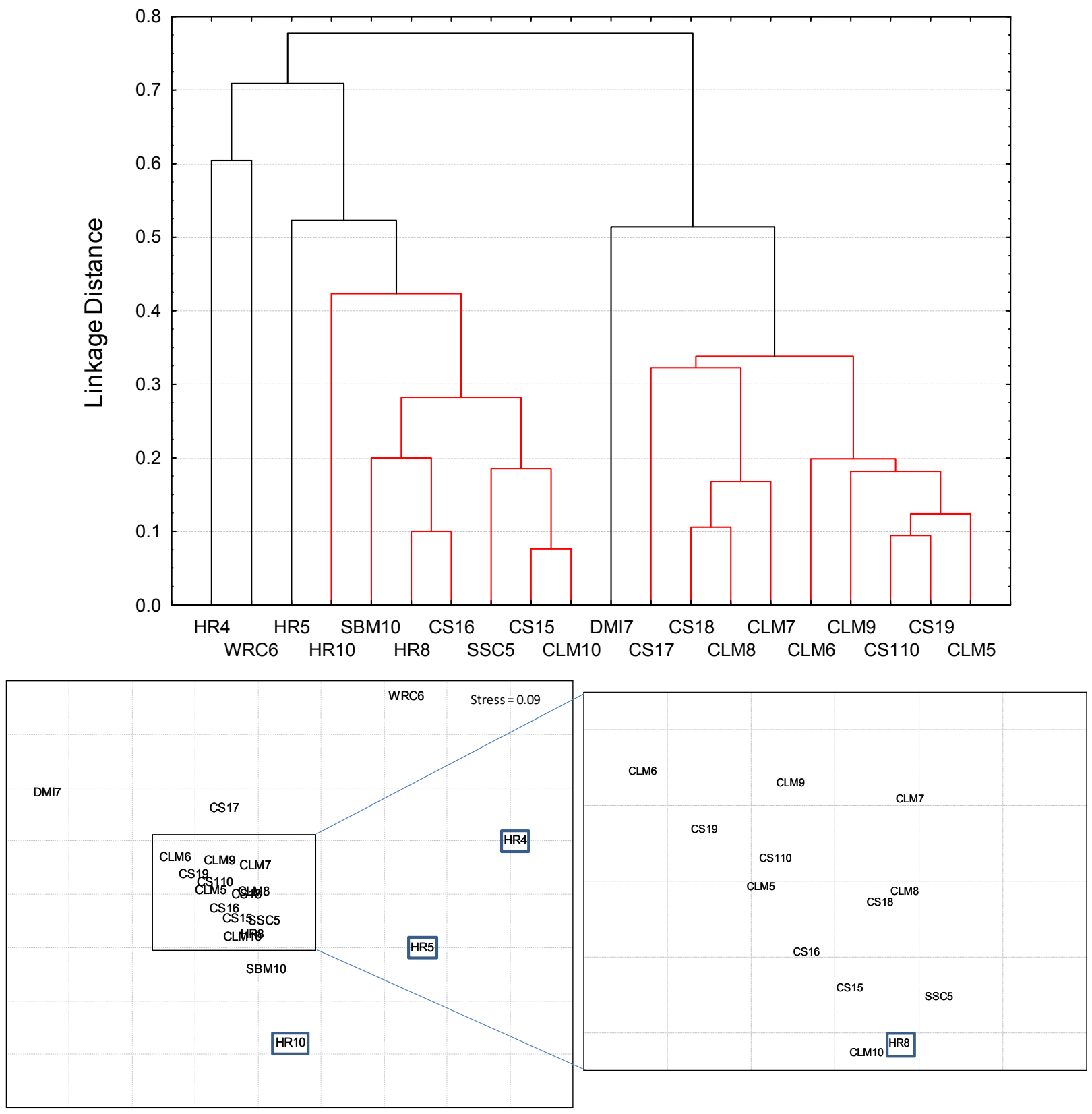

Figure 3.23. Dendrogram (top) and an nMDS plot (bottom) of the similarity between the restoration site Hogan Ranch (blue boxes) relative to selected reference sites using complete linkage and relative Sørensen's similarity. Red lines on the dendrogram represent a similarity greater than 50\%. Numbers after the site codes represent the year of sampling (e.g., $6=2006$ ). 
Table 3.18. Similarity of the shrub strata between the restoration site Mirror Lake and mainstem forested riparian reference sites between $\mathrm{rkm} 75$ and $\mathrm{rkm}$ 235. Numbers after the site codes represent the year of sampling (e.g., $6=2006$ ). Restoration sites are highlighted in yellow. Similarity values greater than $50 \%$ are highlighted in light yellow and greater than $75 \%$ are highlighted in green.

\begin{tabular}{lcccccc}
\hline & CCR09 & GCR10 & SRR08 & ML08 & ML09 & ML10 \\
\hline CCR09 & 1.00 & 0.35 & 0.61 & 0.29 & 0.31 & 0.31 \\
GCR10 & 0.35 & 1.00 & 0.60 & 0.26 & 0.31 & 0.26 \\
SRR08 & 0.61 & 0.60 & 1.00 & 0.30 & 0.34 & 0.29 \\
ML08 & 0.29 & 0.26 & 0.30 & 1.00 & 0.81 & 0.81 \\
ML09 & 0.31 & 0.31 & 0.34 & 0.81 & 1.00 & 0.81 \\
ML10 & 0.31 & 0.26 & 0.29 & 0.81 & 0.81 & 1.00 \\
\hline
\end{tabular}

Table 3.19. Similarity of the tree strata between the restoration site Mirror Lake and mainstem forested riparian reference sites between $\mathrm{rkm} 75$ and $\mathrm{rkm}$ 235. Numbers after the site codes represent the year of sampling (e.g., $6=2$ 006). Restoration sites are highlighted in yellow. Similarity values greater than $50 \%$ are highlighted in light yellow and greater than $75 \%$ are highlighted in green.

\begin{tabular}{lcccccc}
\hline & CCR09 & GCR10 & SRR08 & ML08 & ML09 & ML10 \\
\hline CCR09 & 1.00 & 0.59 & 0.70 & 0.69 & 0.49 & 0.46 \\
GCR10 & 0.59 & 1.00 & 0.59 & 0.75 & 0.88 & 0.85 \\
SRR08 & 0.70 & 0.59 & 1.00 & 0.80 & 0.55 & 0.51 \\
ML08 & 0.69 & 0.75 & 0.80 & 1.00 & 0.73 & 0.70 \\
ML09 & 0.49 & 0.88 & 0.55 & 0.73 & 1.00 & 0.95 \\
ML10 & 0.46 & 0.85 & 0.51 & 0.70 & & 1.00 \\
\hline
\end{tabular}


Table 3.20. Similarity of the shrub strata between the Sandy River Delta restoration site (four subareas) and mainstem forested riparian reference sites between $\mathrm{rkm} 75$ and $\mathrm{rkm} 235$. Numbers after the site codes represent the year of sampling. Restoration sites are highlighted in yellow. Similarity values greater than $50 \%$ are highlighted in light yellow and greater than $75 \%$ are highlighted in green.

\begin{tabular}{|c|c|c|c|c|c|c|c|c|c|c|c|c|c|c|c|}
\hline & CCR09 & GCR10 & SRR08 & 1SRD08 & 2SRD08 & 3SRD08 & 4SRD08 & 1SRD09 & 2SRD09 & 3SRD09 & 4SRD09 & 1SRD10 & 2SRD10 & 3SRD10 & 4SRD1C \\
\hline CCR09 & 1.00 & 0.35 & 0.61 & 0.61 & 0.32 & 0.34 & 0.43 & 0.52 & 0.37 & 0.53 & 0.55 & 0.42 & 0.50 & 0.37 & 0.47 \\
\hline GCR10 & 0.35 & 1.00 & 0.60 & 0.34 & 0.20 & 0.23 & 0.34 & 0.38 & 0.26 & 0.39 & 0.37 & 0.29 & 0.32 & 0.21 & 0.33 \\
\hline SRR08 & 0.61 & 0.60 & 1.00 & 0.57 & 0.23 & 0.21 & 0.39 & 0.49 & 0.28 & 0.43 & 0.52 & 0.34 & 0.42 & 0.24 & 0.38 \\
\hline 1SRD08 & 0.61 & 0.34 & 0.57 & 1.00 & 0.36 & 0.33 & 0.47 & 0.65 & 0.38 & 0.53 & 0.54 & 0.62 & 0.48 & 0.39 & 0.47 \\
\hline 2SRD08 & 0.32 & 0.20 & 0.23 & 0.36 & 1.00 & 0.34 & 0.43 & 0.46 & 0.82 & 0.34 & 0.41 & 0.45 & 0.62 & 0.40 & 0.45 \\
\hline 3SRD08 & 0.34 & 0.23 & 0.21 & 0.33 & 0.34 & 1.00 & 0.26 & 0.27 & 0.44 & 0.46 & 0.27 & 0.33 & 0.49 & 0.77 & 0.28 \\
\hline 4SRD08 & 0.43 & 0.34 & 0.39 & 0.47 & 0.43 & 0.26 & 1.00 & 0.55 & 0.43 & 0.44 & 0.65 & 0.45 & 0.42 & 0.30 & 0.66 \\
\hline 1SRD09 & 0.52 & 0.38 & 0.49 & 0.65 & 0.46 & 0.27 & 0.55 & 1.00 & 0.47 & 0.47 & 0.60 & 0.56 & 0.50 & 0.29 & 0.49 \\
\hline 2SRD09 & 0.37 & 0.26 & 0.28 & 0.38 & 0.82 & 0.44 & 0.43 & 0.47 & 1.00 & 0.40 & 0.44 & 0.41 & 0.67 & 0.48 & 0.42 \\
\hline 3SRD09 & 0.53 & 0.39 & 0.43 & 0.53 & 0.34 & 0.46 & 0.44 & 0.47 & 0.40 & 1.00 & 0.47 & 0.61 & 0.48 & 0.63 & 0.47 \\
\hline 4SRD09 & 0.55 & 0.37 & 0.52 & 0.54 & 0.41 & 0.27 & 0.65 & 0.60 & 0.44 & 0.47 & 1.00 & 0.44 & 0.53 & 0.32 & 0.64 \\
\hline 1SRD10 & 0.42 & 0.29 & 0.34 & 0.62 & 0.45 & 0.33 & 0.45 & 0.56 & 0.41 & 0.61 & 0.44 & 1.00 & 0.48 & 0.50 & 0.54 \\
\hline 2SRD10 & 0.50 & 0.32 & 0.42 & 0.48 & 0.62 & 0.49 & 0.42 & 0.50 & 0.67 & 0.48 & 0.53 & 0.48 & 1.00 & 0.57 & 0.52 \\
\hline 3 SRD10 & 0.37 & 0.21 & 0.24 & 0.39 & 0.40 & 0.77 & 0.30 & 0.29 & 0.48 & 0.63 & 0.32 & 0.50 & 0.57 & 1.00 & 0.34 \\
\hline 4SRD10 & 0.47 & 0.33 & 0.38 & 0.47 & 0.45 & 0.28 & 0.66 & 0.49 & 0.42 & 0.47 & 0.64 & 0.54 & 0.52 & 0.34 & 1.00 \\
\hline
\end{tabular}


Table 3.21. Similarity of the tree strata between the Sandy River Delta restoration site (four subareas) and mainstem forested riparian reference sites between $\mathrm{rkm} 75$ and $\mathrm{rkm} 235$. Numbers after the site codes represent the year of sampling. Restoration sites are highlighted in yellow. Similarity values greater than $50 \%$ are highlighted in light yellow and greater than $75 \%$ are highlighted in green.

\begin{tabular}{|c|c|c|c|c|c|c|c|c|c|c|c|c|c|c|c|}
\hline & CCR09 & GCR10 & SRR08 & 1SRD08 & 2SRD08 & 3SRD08 & 4SRD08 & 1SRD09 & 2SRD09 & 3SRD09 & 4SRD09 & 1SRD10 & 2SRD10 & 3SRD10 & 4SRD10 \\
\hline CCR09 & 1.00 & 0.59 & 0.70 & 0.61 & 0.52 & 0.51 & 0.57 & 0.58 & 0.43 & 0.38 & 0.57 & 0.53 & 0.36 & 0.37 & 0.51 \\
\hline GCR10 & 0.59 & 1.00 & 0.59 & 0.90 & 0.87 & 0.90 & 0.90 & 0.93 & 0.82 & 0.76 & 0.84 & 0.91 & 0.75 & 0.76 & 0.87 \\
\hline SRR08 & 0.70 & 0.59 & 1.00 & 0.67 & 0.60 & 0.56 & 0.63 & 0.64 & 0.51 & 0.46 & 0.64 & 0.58 & 0.42 & 0.44 & 0.58 \\
\hline 1SRD08 & 0.61 & 0.90 & 0.67 & 1.00 & 0.88 & 0.87 & 0.95 & 0.95 & 0.80 & 0.76 & 0.89 & 0.90 & 0.73 & 0.75 & 0.89 \\
\hline 2SRD08 & 0.52 & 0.87 & 0.60 & 0.88 & 1.00 & 0.86 & 0.89 & 0.88 & 0.84 & 0.82 & 0.85 & 0.90 & 0.72 & 0.74 & 0.89 \\
\hline 3SRD08 & 0.51 & 0.90 & 0.56 & 0.87 & 0.86 & 1.00 & 0.89 & 0.92 & 0.89 & 0.86 & 0.84 & 0.90 & 0.83 & 0.84 & 0.88 \\
\hline 4SRD08 & 0.57 & 0.90 & 0.63 & 0.95 & 0.89 & 0.89 & 1.00 & 0.93 & 0.80 & 0.77 & 0.94 & 0.89 & 0.73 & 0.75 & 0.91 \\
\hline 1SRD09 & 0.58 & 0.93 & 0.64 & 0.95 & 0.88 & 0.92 & 0.93 & 1.00 & 0.85 & 0.80 & 0.88 & 0.93 & 0.78 & 0.79 & 0.88 \\
\hline 2SRD09 & 0.43 & 0.82 & 0.51 & 0.80 & 0.84 & 0.89 & 0.80 & 0.85 & 1.00 & 0.95 & 0.76 & 0.83 & 0.89 & 0.91 & 0.81 \\
\hline 3SRD09 & 0.38 & 0.76 & 0.46 & 0.76 & 0.82 & 0.86 & 0.77 & 0.80 & 0.95 & 1.00 & 0.72 & 0.78 & 0.89 & 0.92 & 0.78 \\
\hline 4SRD09 & 0.57 & 0.84 & 0.64 & 0.89 & 0.85 & 0.84 & 0.94 & 0.88 & 0.76 & 0.72 & 1.00 & 0.84 & 0.67 & 0.70 & 0.87 \\
\hline 1SRD10 & 0.53 & 0.91 & 0.58 & 0.90 & 0.90 & 0.90 & 0.89 & 0.93 & 0.83 & 0.78 & 0.84 & 1.00 & 0.77 & 0.78 & 0.91 \\
\hline 2SRD10 & 0.36 & 0.75 & 0.42 & 0.73 & 0.72 & 0.83 & 0.73 & 0.78 & 0.89 & 0.89 & 0.67 & 0.77 & 1.00 & 0.91 & 0.74 \\
\hline 3SRD10 & 0.37 & 0.76 & 0.44 & 0.75 & 0.74 & 0.84 & 0.75 & 0.79 & 0.91 & 0.92 & 0.70 & 0.78 & 0.91 & 1.00 & 0.77 \\
\hline 4SRD10 & 0.51 & 0.87 & 0.58 & 0.89 & 0.89 & 0.88 & 0.91 & 0.88 & 0.81 & 0.78 & 0.87 & 0.91 & 0.74 & 0.77 & 1.00 \\
\hline
\end{tabular}




\subsubsection{Tidal Channels}

Tidal channels are a critical component of wetlands in the LCRE and are important in the conveyance of water to and from the sites. The morphology of these features is one aspect of a restoration site that can be measured against reference systems. One method for comparison is to evaluate the relationship between channel length and channel area at the outlet. In general, a longer channel results in a greater area at the outlet (Figure 3.24). When this relationship does not hold true, then some factor must be affecting the relationship. For example, a marsh that has subsided during diking would result in a greater quantity of water moving in and out of the system and could, in turn, result in a deeper channel outlet relative to channel length (Diefenderfer et al. 2008). This factor could explain the greater channel areas measured at the Kandoll Farm restoration site and two of the historically breached sites (Figure 3.24). In contrast, the Fort Clatsop restoration site has a smaller than expected outlet area, which could possibly be explained by a constriction at the channel mouth.
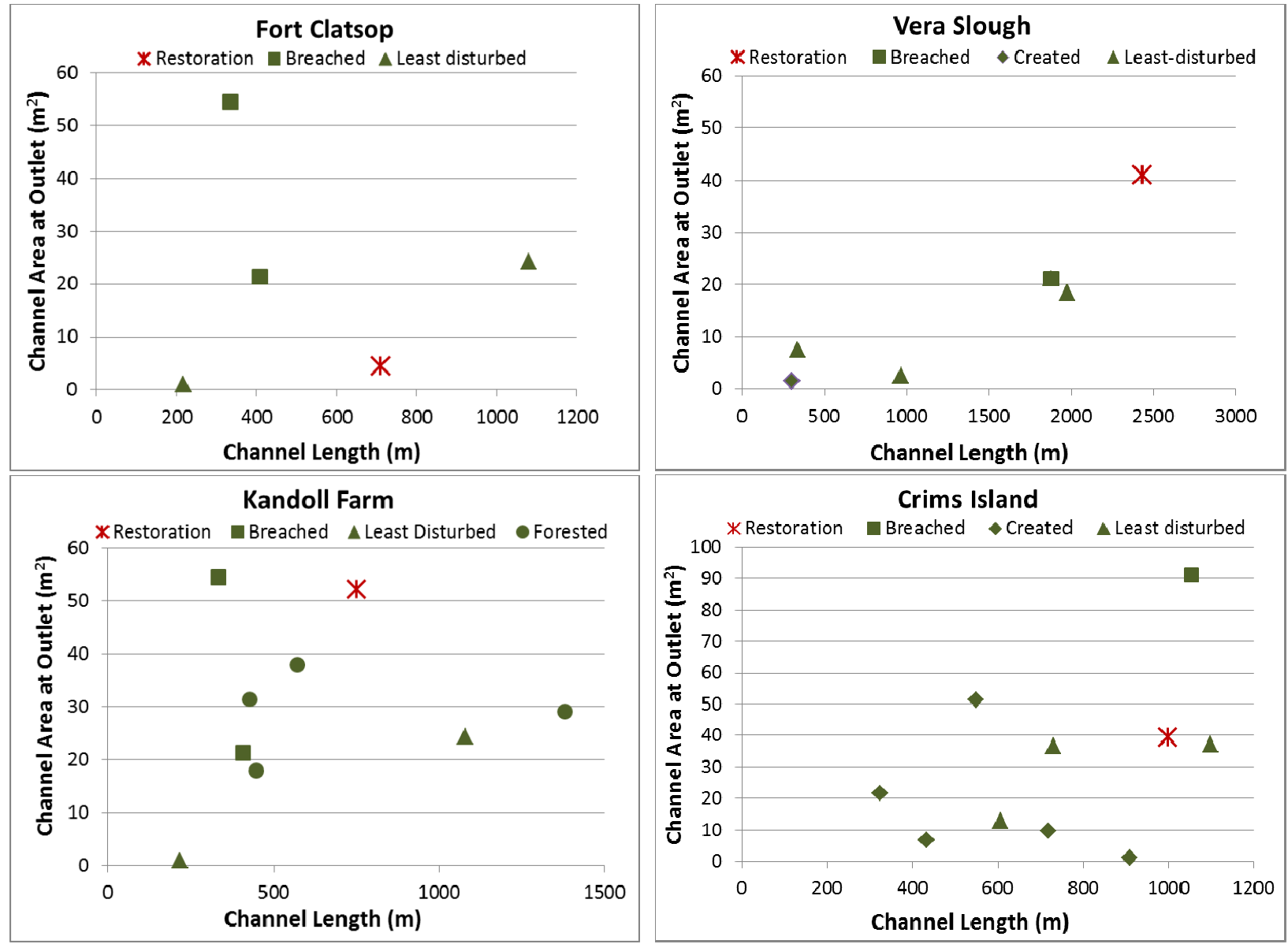

Figure 3.24. Relationship between channel length and channel cross sectional area at the outlet for restoration (red points) and associated reference sites (green points). Note that the $x$-axes are variable on the plots. 
Another morphological metric is the relationship between channel width and depth at the outlet. Fort Clatsop and Kandoll Farm have the expected channel morphometry based on the reference sites, while Vera Slough and Crims Island are deeper than what would be expected for their width (Figure 3.25). The depth at Vera Slough immediately inside and outside the tide gate increased postrestoration, which may be explained by scouring due to the increased flows through the tide gates. At Crims Island, the channel was presumably excavated to the observed depth.
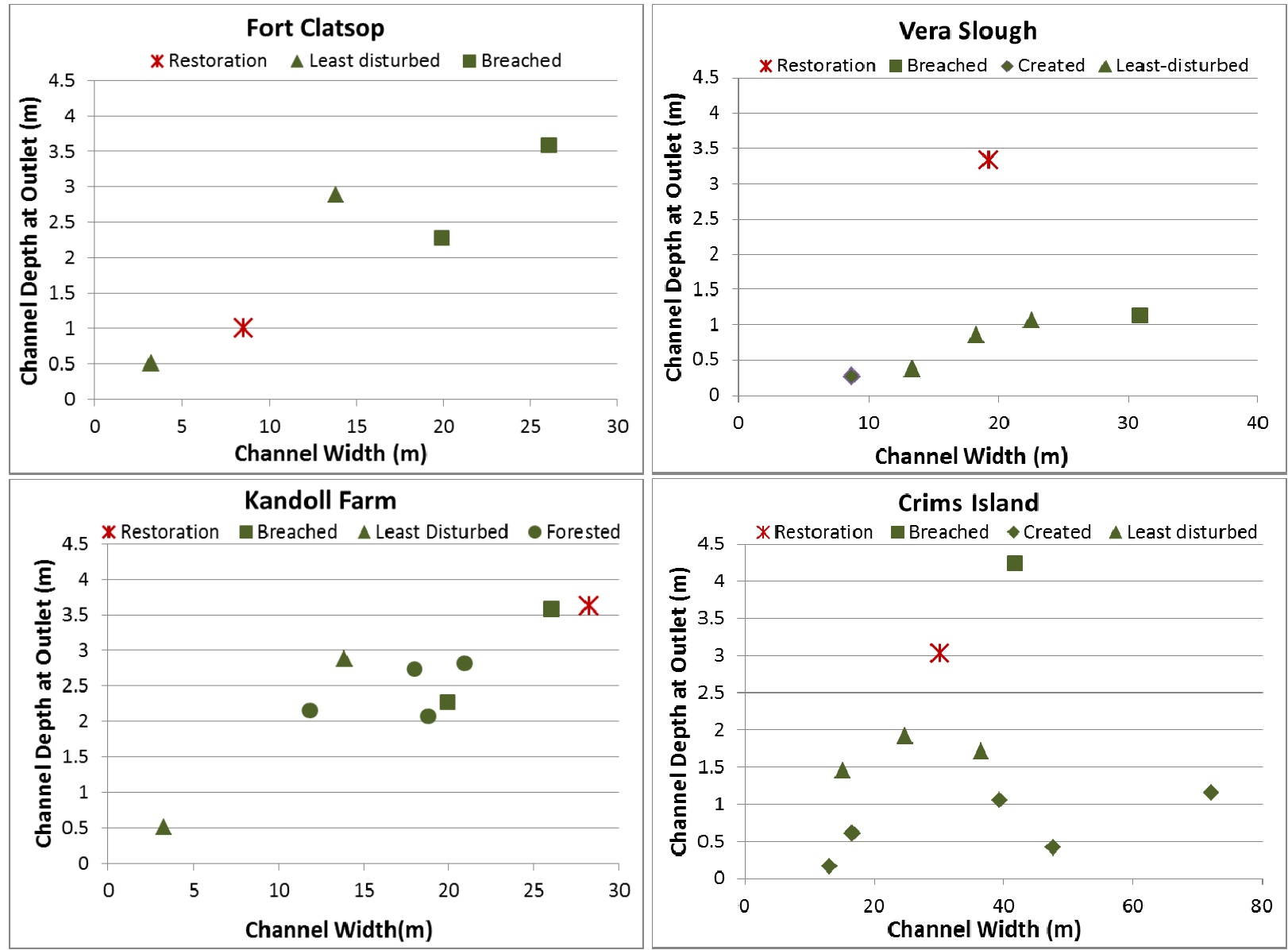

Figure 3.25. Relationship between channel width and channel depth at the outlet for restoration and associated reference sites. Note that the $x$-axes are variable on the plots. 


\subsection{Conclusions and Recommendations}

\subsection{Conclusions}

We summarize the conclusions from the Reference Site study according to two main topics: 1) gradients in the vegetation assemblages relative to hydrodynamics and other factors; and 2) the relative similarity of restored sites to reference sites. Our conclusions are provided in the following subsections.

\subsubsection{Vegetation Assemblage Gradients}

Shallow-water vegetation assemblages show distinct differences along the gradient between the mouth of the river and the upstream end of the estuary at Bonneville Lock and Dam. There are three zones based on species richness; the central region (rkm 50 to $\mathrm{rkm} \mathrm{150)}$ has the greatest number of species, and the upper and lower ends of the estuary have lower numbers of species. These three species richness zones can be characterized hydrodynamically as tidal-dominated, mixed tidal and riverdominated, and river-dominated, moving from the mouth of the Columbia River to Bonneville Dam.

We hypothesize that fewer vegetation species are physiologically adapted to the extreme inundation in the upper end of the estuary, and, likewise, few are adapted to the tidal variability and salinity in the lower estuary. The fact that the mixed zone contains the greatest number of species suggests that the natural ecological disturbance regime may be lower there, and there may be a larger species pool adapted for these conditions in this zone. This intermediate disturbance hypothesis has been used in many ecosystems to describe the conditions that result in higher species diversity (e.g., Levin and Paine 1974, Connell 1978, Bertness and Ellison 1987).

Further examination of the hydrologic gradient revealed that the estuary can be divided further into five zones, driven primarily by salinity intrusion at the lower end, and stronger fluvial flooding influence at the upper end. The breaks for these zones occur at approximately rkm 40, 104, 136, and 181. These breaks are preliminary and should be refined with additional data in areas of sparse sites and with other hydrologic analyses currently underway (Jay et al. in revision).

The five hydro-vegetation zones developed from this analysis provide a means of determining the ranges of controlling factors (e.g., elevation, hydrology, accretion rates) at reference sites within each zone. These ranges can then be used to inform restoration planning for sites within each zone. Further, the zones provide a means of comparing restoration sites to relevant reference sites that have similar factors controlling their habitat structure, as discussed below.

The elevation range for the major habitat types (e.g., emergent, shrub, or forested wetland) within a zone is small (i.e., $<2 \mathrm{~m}$ ), which strongly suggests that elevation/hydrodynamics must be carefully considered 1) in the design of wetland restoration sites, 2) the analysis of differences between sites, and 3 ) the trajectories and rate of development of restored sites.

With the results from this analysis, the elevation and possibly the growing season SEV can be used to predict species presence at sites within the same hydro-vegetation zone. For example, the invasive species reed canary-grass (Phalaris arundinacea) covered the widest range in elevation of any species. In 
general, these data on elevations of vegetation species should help in planning restoration actions to maximize native species and minimize the invasion of reed canary-grass into new sites.

\subsubsection{Relative Similarity of Restored to Reference Sites}

In this section, we summarize the findings from the restoration and reference site comparison then also provide a judgment of the usefulness of the metric and the analysis as a restoration performance measure.

Sediment Accretion. Most restored sites showed initiation of the process of sedimentation. Accretion indicates that the sites are behaving as sinks of sediment and probably organic matter-two processes indicative of wetland systems. Accretion rates tended to be greater in restored sites as compared to the least-disturbed reference sites.

Usefulness of metric: Sediment accretion is required to build wetland elevations and is easily and cost-effectively measured in the field. This metric provided a valuable means of comparing restoration to reference conditions in the analysis.

Elevation. Elevations of previously diked restored sites were lower than reference sites. Again, this suggests that accretion is needed to restore the sites to the historical vegetation assemblage. The excavated site was more similar to reference elevations than the other hydrologically reconnected sites.

Usefulness of metric: This metric can be difficult and expensive to measure in the field, but is invaluable to determine the likelihood of a site establishing the target hydrologic patterns and vegetation community. The simple comparison of the average, minimum, and maximum elevations proved a simple means of comparing the site elevations.

Inundation. Natural hydrological connection and dynamics were restored at the two sites where sufficient hydrological data were available. The hydrologic patterns are likely driving the development and function of the restored sites.

Usefulness of metric: Hydrologic data are essential to determining whether a site has the necessary processes for wetland development. The lack of data from restoration sites resulted in few comparisons, however, we feel the analysis of SEV could be a useful means of evaluating the effect of hydrologic patterns on vegetation particularly when the elevation or hydrology are expected to be different from reference conditions.

Water Temperature. Water temperature in restored and reference sites typically first exceeded the WADOE threshold value for juvenile salmon in late spring. In a few cases, the temperature exceedance occurred later in reference sites than at the restoration sites, likely due to proximity to the main channel and local effects of shade. At the few restoration sites where we had data from multiple sensors within a site, patterns were evident relative to the distance from the outlet or the presence/absence of perennial stream inputs. We did not have pre-restoration data on temperatures but, based on data from a few sites collected before reconnection, we believe that water temperature after reconnection probably remained below the threshold longer as compared to pre-reconnection at the sites we studied. 
Usefulness of metric: Temperature is a useful metric for evaluating conditions within wetland areas, particularly habitat function for aquatic species. The date of first exceedance of a temperature criterion is a viable method for determining differences between sites and also for evaluating the condition of the habitat provided at a site.

Vegetation Composition. The bivariate analysis showed that the composition of selected species at some restoration sites was tending toward the composition at the reference sites. The probability of occurrence showed that the species composition of the highest-cover species at the restoration sites was not the same as that of the reference sites, although some similar species were present and increasing over time. Invasive species, particularly reed canary-grass, were a problem at all restoration sites.

Usefulness of metric: The bivariate analysis is a useful way to compare the cover and composition of desired species. The analysis is most useful when reed canary-grass is not highly dominant in the reference sites that are used to compare to the restoration site. This species was not included in the bivariate analysis because it is not one that is "desirable" in these systems. However, the species is very dominant and affects the cover of many other species that occur within the same elevation range at both restoration and some reference sites.

The probability of occurrence analysis was a useful way to look at the most common species at the sites and compare the cover and composition over time and between the restoration and reference sites.

Vegetation Similarity. The vegetation assemblages at nearly all restoration sites had very low similarity to reference site vegetation. Hogan Ranch and the sites planted with shrubs and trees showed the highest similarity. Sites that were historically forested swamps, and had been converted to pasture land, showed the lowest similarities to their reference sites. Where data were available for multiple years, restoration sites showed a decreasing similarity from the earliest sampling to the most recent. This suggests that the vegetation is changing rapidly from the initial conditions. Based on previous studies (e.g., Thom et al. 2002), we suspect that similarity between restored sites and their reference sites will increase measurably over time but not for at least another 5-10 years.

This analysis showed there to also be variability between the reference sites, which could be caused by factors such as recent and historical disturbances (e.g., dredged material placement). This variability illustrates the need to evaluate reference site differences and possibly further stratify the reference sites for comparison to restoration sites.

The reference site similarity was also variable between years. Thom et el. (2002) found similar results and suggests using the long-term average similarity in reference sites to establish a target similarity between the restoration site and reference site. Because most sites were measured in one year only, and not always in the same year for all reference sites in the zone, this temporal variability must be included in determining the target similarity for the restoration sites.

Usefulness of metric: The similarity index is a very useful way to make broad comparisons based on the vegetation cover and composition between sites and over time. 
Channel Morphometry. The channel length plotted against channel cross sectional area at the mouth was an effective means of comparing the restoration and reference sites. Of the four restoration sites compared, one appeared to have too small of a channel outlet, one was unnecessarily large, and two were within the same range or at the expected ratio found at the reference sites. We suspect that the restored channels will trend toward reference site dimensions if hydrological connection is unconstrained.

Channel width at the outlet plotted against the channel depth at the outlet confirmed that two of the channels had similar dimensions to the reference channels and two were considerably deeper relative to the width as compared to the reference channels. Interestingly, these two sites were also the ones with the most similar length-to-area ratios, so perhaps the deeper channels are necessary to adequately drain the area at these sites.

Usefulness of metric: Analysis of channel morphometry can be used to determine the similarity of restoration channels to reference channels when other metrics of hydraulic geometry are not available (e.g., catchment area and total channel length; see Diefenderfer et al. 2008). We found that the primary channel length versus crosssectional area at the mouth may be a useful measure. However, because channels in reference systems are often complex this analysis should be compared to reference sites using the complete channel network to determine if the relationship is valid. The widthto-depth ratio of channel outlet is useful to evaluate whether a restoration channel is similar to reference channels; however, it does not reflect whether these dimensions are appropriate relative to the size of the site.

Overall, our findings provide new information on factors structuring shallow water vegetated habitats along the entire estuary gradient. The relationships between location, hydrology, and elevation provide valuable potential predictors useful in restoration planning, and to evaluate the rates and trajectories of restored sites.

\subsection{Recommendations}

The following recommendations resulting from this study and are specific to the methods for future analysis. These are not recommendations for restoration actions.

\subsubsection{Data Management}

Specific recommendations for data management include the following:

- Data organization and summarizing needs to be standardized across data collection efforts.

- Develop continuous datasets for all time-series metrics.

- Use USDA plant database for vegetation identification (or identify which field guide used).

- Record vegetation data using scientific name, rather than common name

- Measure elevation data in NAVD88 via local benchmark then convert to the Columbia River Datum where appropriate (i.e., above rkm 35 in the mainstem; not in tributary sites).

- Compile summarized data into one database/spreadsheet for analysis. 


\subsubsection{Reference to Restoration Site Comparisons}

The following recommendations would improve the ability to make comparisons between reference sites and restoration sites in the future:

- The differences between reference sites because of recent and historical disturbances need to be evaluated and possibly stratified further prior to comparison to restoration sites.

- Interannual variability needs to be better quantified at reference sites within the estuary.

- Channels in reference systems are often complex. The analysis conducted here on primary channel length should be compared to one using the complete channel network to determine if the relationship between primary channel length and area at channel outlet is valid.

- Additional monitoring data are needed at restoration sites to better understand if sites are developing toward fully functioning and resilient ecosystems, to inform the adaptive management process, and ultimately improve restoration action effectiveness in the future. 



\subsection{References}

Aarssen LW and BS Schamp. 2002. Predicting distributions of species richness and species size in regional floras: Applying the species pool hypothesis to the habitat templet model. Perspectives in Plant Ecology, Evolution and Systematics 5:3-12.

Araya YN, J Silvertown, DJ Gowing, KJ McConway, HP Linder, and G Midgley. 2011 A fundamental, eco-hydrological basis for niche segregation in plant communities. New Phytologist 189(1):253-258.

Bertness MD and AM Ellison. 1987. Determinants of pattern in a New England salt marsh plant community. Ecological Monographs 57:129-147.

Borde AB, HL Diefenderfer, SA Zimmerman, and RM Thom. 2008a. Progress Report to the Lower Columbia River Estuary Partnership Summarizing 2008 Reference Site Study. PNWD-4005, BattellePacific Northwest Division, Richland, Washington.

Borde AB, SA Zimmerman, and KL Sobocinski. 2008b. Crims Island - Monitoring Data Summary. In Evaluating Cumulative Ecosystem Response to Restoration Projects in the Columbia River Estuary, Annual Report 2007, GE Johnson and HL Diefenderfer (eds). PNNL-17437, Pacific Northwest National Laboratory, Richland, Washington.

Borde AB, SA Zimmerman, RM Kaufmann, HL Diefenderfer, NK Sather, and RM Thom. 2011. Lower Columbia River and Estuary Restoration Reference Site Study: 2010 Final Report and Site Summaries. PNWD-4262, Battelle-Pacific Northwest Division, Richland, Washington.

Borde AB, RM Kaufmann, VI Cullinan, SA Zimmerman, and CL Wright. 2012. Lower Columbia River and Estuary Habitat Monitoring 2011 Annual Report. PNNL-21128, Pacific Northwest National Laboratory, Richland Washington.

Bottom DL, CA Simenstad, J Burke, AM Baptista, DA Jay, KK Jones, E Casillas, and M Schiewe. 2005. Salmon at River's End: the Role of the Estuary in the Decline and Recovery of Columbia River Salmon. NOAA Technical Memorandum NMFS-NWFSC-68, National Oceanic and Atmospheric Administration (NOAA) Fisheries, Northwest Fisheries Science Center, Seattle, Washington.

Burke JL. 2010. Georeferenced Historical Topographic Survey Maps of the Columbia River Estuary. School of Aquatic and Fishery Sciences, University of Washington, Seattle, Washington

Chawla A, DA Jay, AM Baptista, M Wilkin, and C Seaton. 2008. Seasonal variability and estuary-shelf interactions in circulation dynamics of a river-dominated estuary. Estuaries and Coasts 31(2):269-288.

Christy JA and JA Putera. 1993. Lower Columbia River Natural Area Inventory. Oregon Natural Heritage Program, Portland, Oregon.

Connell JH. 1978. Diversity in tropical rain forests and coral reefs. Science 199:1302-1310. 
Diefenderfer HL, RM Thom, GE Johnson, JR Skalski, KA Vogt, BD Ebberts, GC Roegner, and EM Dawley. 2011. A levels-of-evidence approach for assessing cumulative ecosystem response to estuary and river restoration programs. Ecological Restoration 29:111-132.

Diefenderfer HL and DR Montgomery. 2009. Pool spacing, channel morphology, and the restoration of tidal forested wetlands of the Columbia River, U.S.A. Restoration Ecology 17:158-168. doi:10.1111/j.1526-100X.2008.00449.x.

Diefenderfer HL, AM Coleman, AB Borde, and IA Sinks. 2008. Hydraulic geometry and microtopography of tidal freshwater forested wetlands and implications for restoration, Columbia River, U.S.A. Ecohydrology and Hydrobiology 8:339-361. doi:10.2478/v10104-009-0027-7.

Downes BJ, LA Barmuta, PG Fairweather, DP Faith, MJ Keough, PS Lake, BD Mapstone, and GP Quinn. 2002. Monitoring Ecological Impacts: Concepts and Practice in Flowing Waters. Cambridge University Press, Cambridge, UK.

Elliot CM. 2004. Environmental and Historical Factors Driving Vegetation Communities on Russian Island, Columbia River Estuary. M.S. thesis, College of Forest Resources, University of Washington, Seattle.

Ennis S. 2009. Effects of Tide Gate Replacement on Water Temperature in a Freshwater Slough in the Columbia River Estuary. Masters Project in Environmental Science and Management, Portland State University, Portland, Oregon.

Fox DS, S Bell, W Nehlsen, and J Damron. 1984. The Columbia River Estuary: Atlas of Physical and Biological Characteristics. Columbia River Estuary Data Development Program, Columbia River Estuary Study Taskforce, Astoria, Oregon.

Grace JB. 1999. The factors controlling species density in herbaceous plant communities: an assessment. Perspectives in Plant Ecology, Evolution and Systematics 2(1):1-28.

Gowing DJG, CS Lawson, EG Youngs, KR Barber, JS Rodwell, MV Prosser, HL Wallace, JO Mountford, and G Spoor. 2002. The Water Regime Requirements and the Response to Hydrological Change of Grassland Plant Communities. Project BD1310, Institute of Water and Environment, Bedford, UK.

Grime JP. 1979. Plant Strategies and Vegetation Processes. John Wiley \& Sons, Inc., New York.

ISAB 2011. Columbia River Food Webs: Developing a Broader Scientific Foundation for Fish and Wildlife Restoration. Document ISAB 2011-1, Interagency Scientific Advisory Board for the Northwest Power and Conservation Council, Columbia River Basin Indian Tribes, and NOAA Fisheries, Portland, Oregon.

Jay DA, K Leffler, H Diefenderfer, and A Borde. In Revision. Tidal-fluvial and estuarine processes in the lower Columbia River: I. along-channel water level variations, Pacific Ocean to Bonneville Dam. Estuaries and Coasts. 
Johnson G, H Diefenderfer, B Ebberts, C Tortorici, T Yerxa, J Leary, and J Skalski. 2008. Research, Monitoring, and Evaluation for the Federal Columbia River Estuary Program. PNNL-17300, Pacific Northwest National Laboratory, Richland, Washington.

Johnson GE, HL Diefenderfer, RM Thom, GC Roegner, BD Ebberts, JR Skalski, AB Borde, EM Dawley, AM Coleman, DL Woodruff, SA Breithaupt, AS Cameron, CA Corbett, EE Donley, DA Jay, Y Ke, KE Leffler, CB McNeil, CA Studebaker, and JD Tagestad. 2011. Evaluation of Cumulative Ecosystem Response to Restoration Projects in the Lower Columbia River and Estuary, Annual Report 2010. PNNL-20296, Pacific Northwest National Laboratory, Richland, Washington.

Kentula M, R Brooks, S Gwin, C Holland, A Sherman, and J Sifneos. 1992. An Approach to Improving Decision Making in Wetland Restoration and Creation. EPA/600/R-92/150, U.S. Environmental Protection Agency, Environmental Research Laboratory, Corvallis, Oregon.

Kukulka T and DA Jay. 2003a. Impacts of Columbia River discharge on salmonid habitat: 1. a nonstationary fluvial tide model. Journal of Geophysical Research 108(C9):3293, 9-1-9-20.

Kukulka T and DA Jay. 2003b. Impacts of Columbia River discharge on salmonid habitat: 2. changes in shallow-water habitat. Journal of Geophysical Research 108(C9):3294, 10-1-10-16.

Levin SA and RT Paine. 1974. Disturbance, patch formation, and community structure. Proceedings of the National Academy of Sciences 71(7):2744-2747.

Maier GO and CA Simenstad. 2009. The role of marsh-derived macrodetritus to the food webs of juvenile Chinook salmon in a large altered estuary. Estuaries and Coasts 32:984-998.

Mitsch WJ and JG Gosselink. 2000. Wetlands. 3rd ed., John Wiley \& Sons, Inc., New York.

NMFS. 2000. Biological Opinion: Reinitiation of Consultation on Operation of the Federal Columbia

River Power System, Including the Juvenile Fish Transportation Program, and 19 Bureau of Reclamation Projects in the Columbia Basin. National Marine Fisheries Service - Northwest Region, Seattle, Washington. Available at http://www.salmonrecovery.gov/implementation (May 2012).

NMFS. 2004. Biological Opinion: Operation of the Federal Columbia River Power System (FCRPS) Including 19 Bureau of Reclamation Projects in the Columbia Basin (Revised and reissued pursuant to court order, NWF v. NMFS, Civ. No. CV 01-640-RE [D. Oregon]). National Marine Fisheries Service Northwest Region, Seattle, Washington. Available at http://www.salmonrecovery.gov/ (May 2012).

NMFS. 2008. Biological Opinion - Consultation on Remand for Operation of the Federal Columbia River Power System, 11 Bureau of Reclamation Projects in the Columbia Basin and ESA Section 10(a)(1)(A) Permit for Juvenile Fish Transportation Program. National Marine Fisheries Service (NOAA Fisheries) - Northwest Region, Seattle, Washington.

NMFS. 2010. Endangered Species Act Section 7(a)(2) Consultation Supplemental Biological Opinion: Supplemental Consultation on Remand for Operation of the Federal Columbia River Power System, 11 Bureau of Reclamation Projects in the Columbia Basin and ESA Section 10(a)(I)(A) Permit for Juvenile Fish Transportation Program. F/NWR/2010/02096, National Marine Fisheries Service (NOAA Fisheries) - Northwest Region, Seattle, Washington. 
NRCS. 2002. (NRCS). 2002. Wetland determination (WETS) table for Clark County, Washington. Natural Resource Conservation Service, U.S. Department of Agriculture, Washington, D.C. Available at http://www.wcc.nrcs.usda.gov/ftpref/support/climate/wetlands/wa/53011.txt (May 2012).

Parametrix. 2009. Final Report-Mirror Lake Restoration Site - 2008/2009 Culvert and Large Woody Debris Monitoring. Parametrix, Portland, Oregon.

Sather NK, DJ Teal, AJ Storch, GE Johnson, ES Van Dyke, EM Dawley, DR Kuligowski, TA Jones, AJ Bryson, and KL Sobocinski. 2011. Juvenile Salmon and Fish Community Characteristics. In Ecology of Juvenile Salmon in Shallow Tidal Freshwater Habitats of the Lower Columbia River, 2007-2010, GE Johnson, A Storch, JR Skalski, AJ Bryson, C Mallette, AB Borde, E Van Dyke, KL Sobocinski, NK Sather, D Teel, EM Dawley, GR Ploskey, TA Jones, SA Zimmerman, and DR Kuligowski, pp. 2.1-4.35. PNNL-20083, Pacific Northwest National Laboratory, Richland, Washington.

Sherwood CR, DA Jay, RB Harvey, and CA Simenstad. 1990. Historical changes in the Columbia River estuary. Progress in Oceanography 25:299-352.

Shuwen W, Q Pei, L Yang, and L Xi-Ping. 2001. Wetland creation for rare waterfowl conservation: a project designed according to the principles of ecological succession. Ecological Engineering 18:115120.

Simon SD, ME Cardona, BW Wilm, JA Miner, and DT Shaw. 1997. The sum Exceedance value as a measure of wetland vegetation hydrologic tolerance. In Wetland and Riparian Restoration: Taking a Broader View - Proceedings of a Conference, KB Macdonald and F Weinmann (eds). Proceedings of the Society for Ecological Restoration 1995 International Conference, September 14-16, University of Washington, Seattle. EPA 910-R-97-007, U.S. Environmental Protection Agency, Region 10, Seattle, Washington.

Steyer GD, CE Sasser, JM Visser, EM Swenson, JA Nyman, and RC Raynie. 2003. A proposed coastwide reference monitoring system for evaluating wetland restoration trajectories in Louisiana. Journal of Environmental Monitoring and Assessment 81:107-117.

Tabor JE. 1976. Inventory of Riparian Habitats and Associated Wildlife along the Columbia and Snake Rivers. Volume 2A: Lower Columbia River. Oregon Cooperative Research Unit, Oregon State University, Corvallis, Oregon.

Thayer GW, TA McTigue, RJ Salz, DH Merkey, FM Burrows, and PF Gayaldo. 2005. Science-Based Restoration Monitoring of Coastal Habitats, Volume 2: Tools for Monitoring Coastal Habitats. Decision Analysis Series. NOAA Coastal Ocean Program, Silver Spring, Maryland.

Thom RM, R Zeigler, and AB Borde. 2002. Floristic development patterns in a restored elk river estuarine marsh, Grays Harbor, Washington. Restoration Ecology 10(3):487-496. 
Thom RM, GE Johnson, BD Ebberts, CA Studebaker, HL Diefenderfer, and CA Corbett. 2011. Adaptive Management of Ecosystem Restoration in the Lower Columbia River and Estuary. In Evaluation of Cumulative Ecosystem Response to Restoration Projects in the Lower Columbia River and Estuary, GE Johnson GE, HL Diefenderfer, RM Thom, GC Roegner, BD Ebberts, JR Skalski, AB Borde, EM Dawley, AM Coleman, DL Woodruff, SA Breithaupt, AS Cameron, CA Corbett, ED Donley, DA Jay, Y Ke, KE Leffler, CB McNeil, CA Studebaker, and JD Tagestad, pp. 3.1-3.23. PNNL-20296, Pacific Northwest National Laboratory, Richland, Washington. 

Appendix A

\section{Temperature Graphs}





\section{Appendix A}

\section{Temperature Graphs}
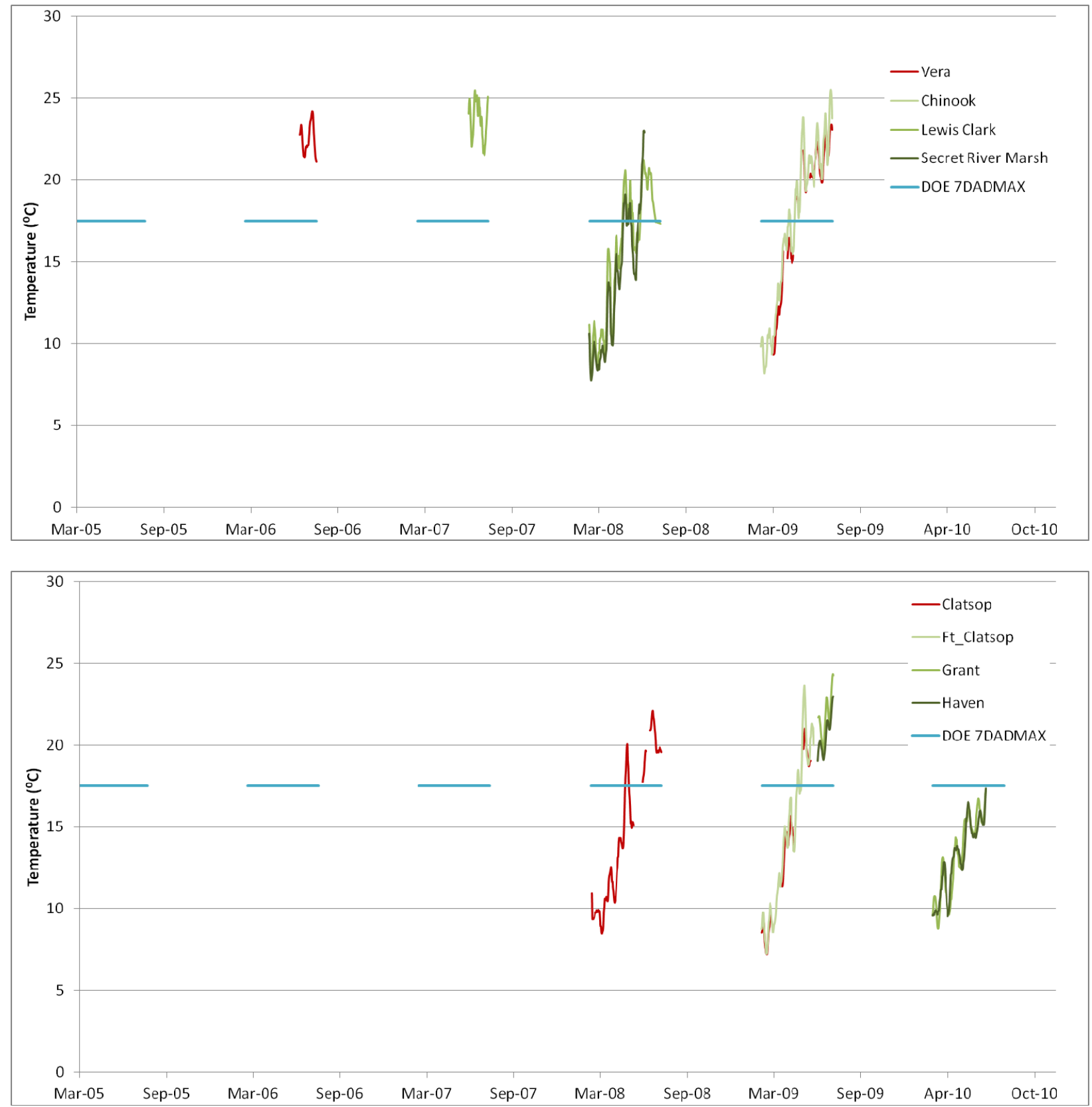

Figure A.1. The seven-day running average of the daily maximum (7DADmax) between March and July for restoration and reference sites in same hydro-vegetation zone and geomorphic setting (tributary vs. main channel). Restoration sites are shown in red and restoration sites in shades of green. 

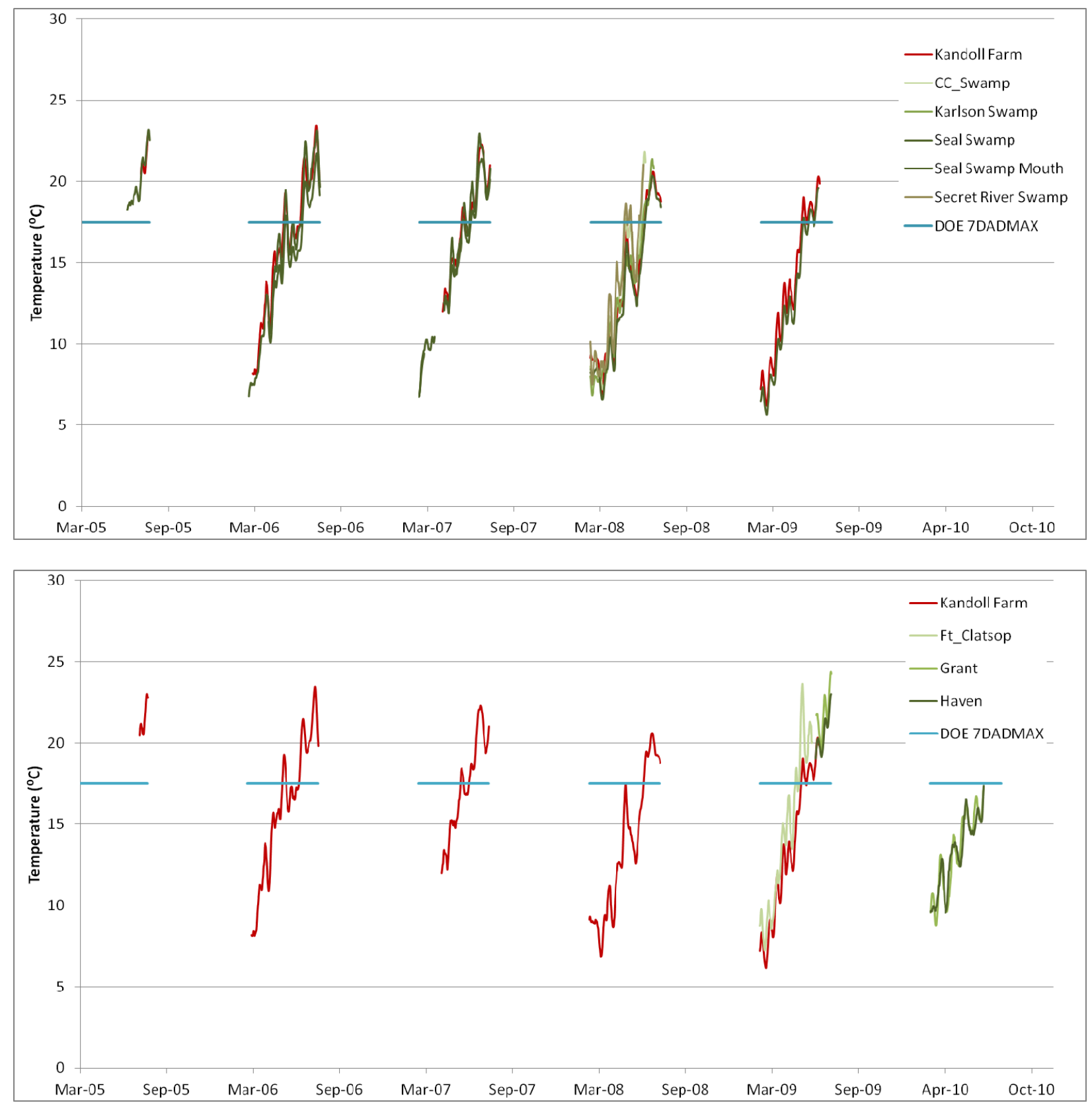

Figure A.1. (contd) 

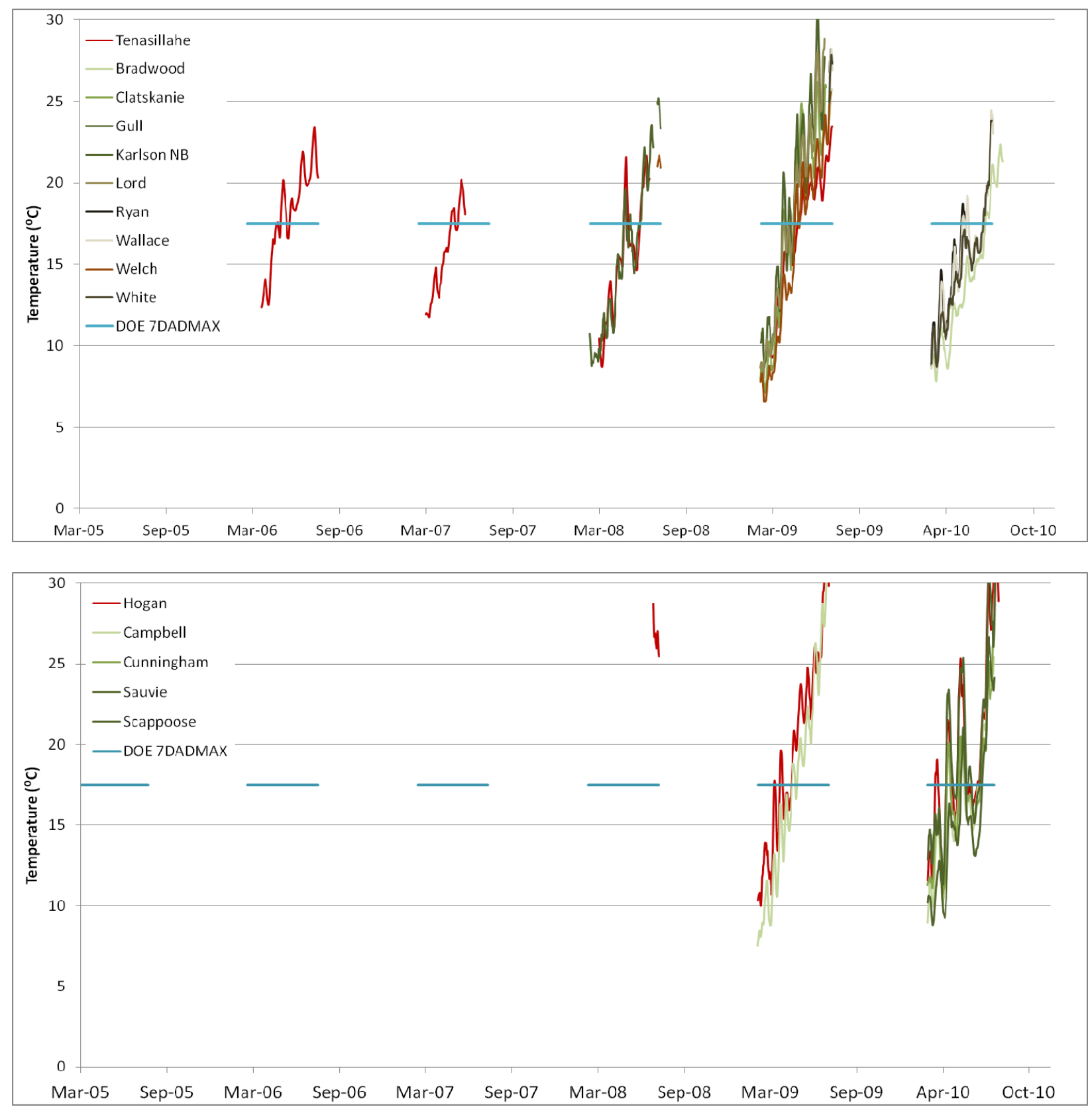

Figure A.1. (contd) 


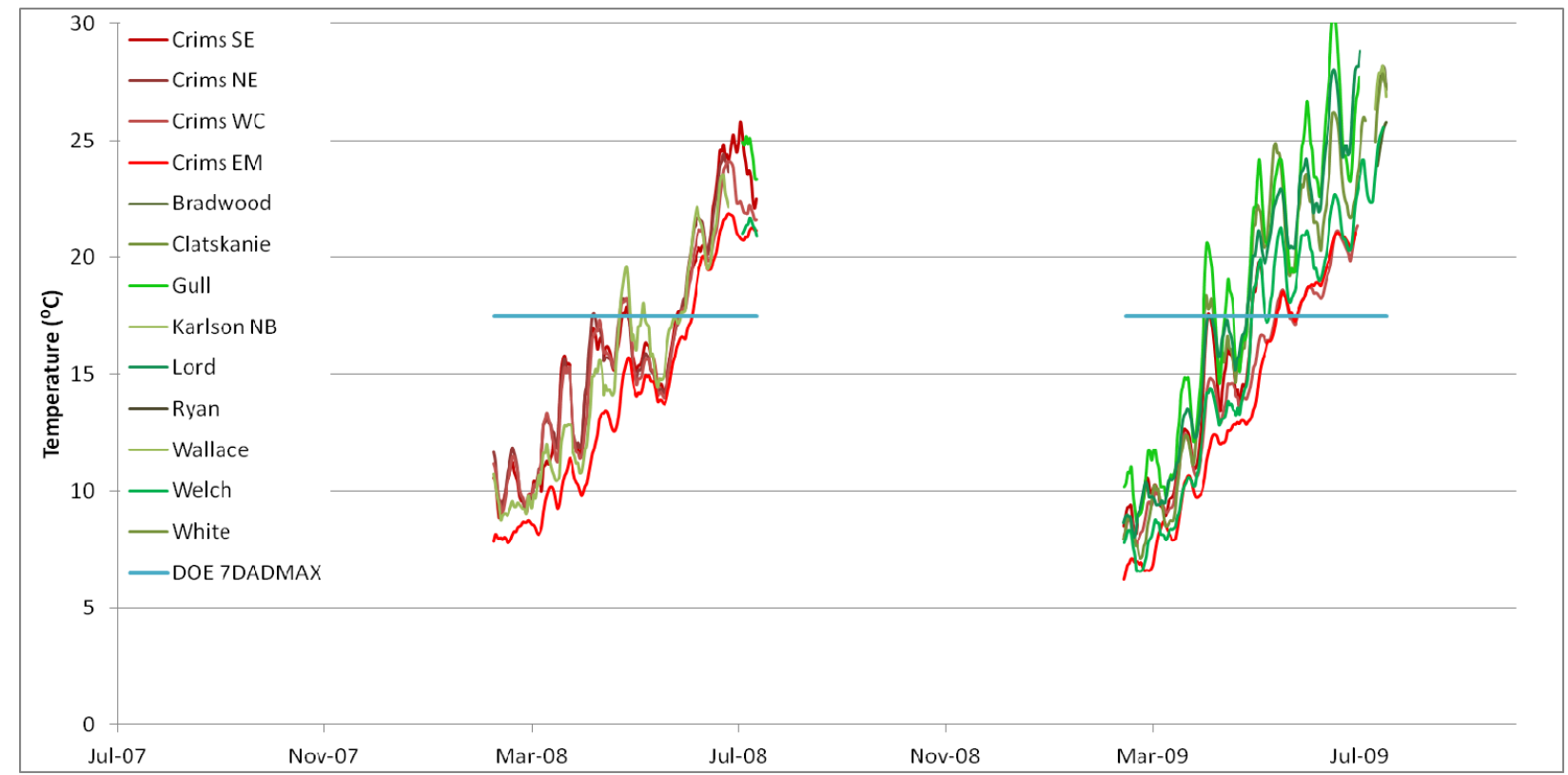

a)

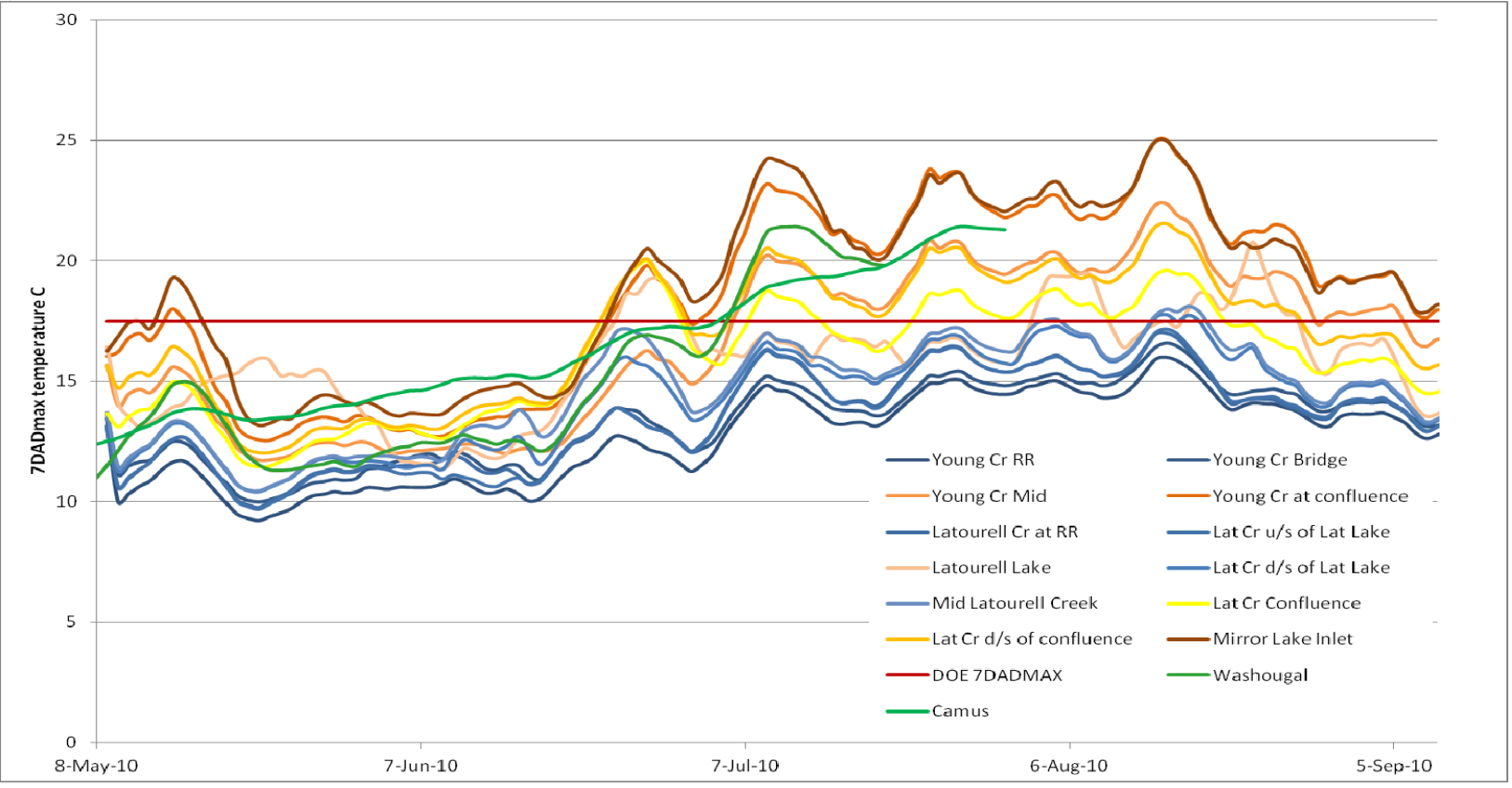

b)

Figure A.2. Temperature from multiple sensors at a) Crims Island and b) Mirror Lake compared to nine and one reference site(s), respectively. The Mirror Lake data is also compared to temperature data from Camas on the mainstem. 
Appendix B

LCR Reference and Restoration Site Study Plant List 



\section{Appendix B}

\section{LCR Reference and Restoration Site Study Plant List}

Table B.1 lists all plant species observed at all reference sites monitored by PNNL from 2005-2010. Table B.2 lists species observed by others during restoration monitoring that were not already included in the PNNL species list. Note that the "Invasive/Weedy" column has not been comprehensively addressed. Species immediately known to be invasive have been noted with a "yes" in the column; however, other species could warrant the same categorization but adequate research has not been conducted in this study to date. 
Table B.1. Plant species observed at all reference sites monitored by PNNL from 2005 through 2010.

\begin{tabular}{|c|c|c|c|c|c|c|c|c|}
\hline Scientific Name & Code & Common Name & $\begin{array}{l}\text { Wetland } \\
\text { Indicator } \\
\text { Status }\end{array}$ & Category & Native & $\begin{array}{l}\text { Invasive/ } \\
\text { Weedy }\end{array}$ & NOTES & $\begin{array}{l}\text { Previous } \\
\text { Species } \\
\text { Code }\end{array}$ \\
\hline \multicolumn{9}{|c|}{ Species observed at reference sites } \\
\hline Acer circinatum & $\mathrm{ACCI}$ & Vine maple & FAC- & Shrub & yes & & & \\
\hline Adiantum aleuticum & ADAL & Aleutian Maidenhair fern & FAC & Fern & yes & & $\begin{array}{l}\text { formerly Adiantum } \\
\text { pedatum }\end{array}$ & ADPE \\
\hline Agrostis capillaris & AGCA & Colonial bentgrass & FAC & Grass & no & & & \\
\hline Agrostis exarata & AGEX & spike bentgrass & FACW & Grass & yes & & & \\
\hline Agrostis gigantea & AGGI & redtop; black bentgrass & NI & Grass & no & & & \\
\hline Agrostis oregonensis & AGOR & Oregon bentgrass & FAC & Grass & yes & & & \\
\hline Agrostis stolonifera L. & AGST & creeping bentgrass & FAC & Grass & no & yes & & \\
\hline Alisma triviale & ALTR & northern water plaintain & OBL & Herb & yes & & $\begin{array}{l}\text { formerly Alisma } \\
\text { plantago-aquatica } \\
\text { var. americanum }\end{array}$ & ALPL \\
\hline Alnus rubra & ALRU & Red alder & FAC & Tree & yes & & & \\
\hline Alopecurus pratensis & ALPR & Meadow foxtail & FACW & Grass & no & & & \\
\hline Amelanchier alnifolia & AMAL & Saskatoon serviceberry & FACU & Shrub & yes & & & \\
\hline Amorpha fruticosa & AMFR & indigo bush & FACW & Shrub & no & yes & & \\
\hline Angelica arguta & ANAR & Sharptooth angelica & FACW & Herb & yes & & & \\
\hline Angelica genuflexa & ANGE & Kneeling angelica & FACW & Herb & yes & & & \\
\hline Apocynum cannabinum & APCA & dogbane, Indian hemp & FAC+ & Herb & yes & & & \\
\hline Aruncus dioicus & ARDI & Goat's beard & FACU+ & Herb & yes & & & \\
\hline Asplenium trichomanes-ramosum & ASTR & Green spleenwort & FACU & Herb & yes & & $\begin{array}{l}\text { formerly Asplenium } \\
\text { viride }\end{array}$ & ASVI \\
\hline Athyrium filix-femina & ATFI & Lady fern & FAC & Fern & yes & & & \\
\hline Atriplex patula & ATPA & spear saltbush & FACW & Herb & yes & & & \\
\hline Beckmannia syzigachne & BESY & American sloughgrass & OBL & Grass & yes & & & \\
\hline Bidens cernua & $\mathrm{BICE}$ & Nodding beggars-ticks & FACW+ & Herb & yes & yes & & \\
\hline Bidens frondosa & BIFR & devil's beggartick & $\mathrm{FACW}+$ & Herb & yes & & & \\
\hline
\end{tabular}


Table B.1. (contd)

\begin{tabular}{|c|c|c|c|c|c|c|c|c|}
\hline Scientific Name & Code & Common Name & $\begin{array}{c}\text { Wetland } \\
\text { Indicator } \\
\text { Status }\end{array}$ & Category & Native & $\begin{array}{c}\text { Invasive/ } \\
\text { Weedy }\end{array}$ & NOTES & $\begin{array}{c}\text { Previous } \\
\text { Species } \\
\text { Code } \\
\end{array}$ \\
\hline Blechnum spicant & BLSP & Deer fern & FAC + & Fern & yes & & & \\
\hline Calamagrostis canadensis & CACA & bluejoint & FACW + & Grass & yes & & & \\
\hline Calamagrostis spp. & CASP2 & reedgrass & & Grass & yes & & & \\
\hline Callitriche heterophylla & CAHE & Twoheaded water starwort & OBL & Herb & yes & & & \\
\hline Caltha palustris & CAPA & Yellow marsh marigold & OBL & Herb & yes & & & \\
\hline Calystegia sepium & CASE & Hedge bindweed & $\mathrm{FAC}$ & Herb & no & & $\begin{array}{l}\text { formerly Convolvulus } \\
\text { sepium }\end{array}$ & $\begin{array}{l}\text { COSE; } \\
\text { COSE1 }\end{array}$ \\
\hline Cardamine angulata & CAAN & Angled bittercress & FACW & Herb & yes & & & \\
\hline Cardamine pensylvanica & CAPE & Pennsylvania bittercress & FACW & Herb & no & & & \\
\hline Carex aperta & CAAP & Columbia sedge & FACW & Sedge & yes & & $\begin{array}{l}\text { nearly exterpated in } \\
\text { CR }\end{array}$ & \\
\hline Carex athrostachya & CAAT & slender-beak sedge & FACW & Sedge & yes & & & \\
\hline Carex comosa & $\mathrm{CACO}$ & Bearded sedge & OBL & Sedge & yes & & sensitive spp in WA & \\
\hline Carex densa & CADE2 & dense dedge & OBL & Sedge & yes & & threatened & \\
\hline Carex deweyana & CADE & Dewey sedge & $\mathrm{FAC}+$ & Sedge & yes & & & \\
\hline Carex disperma & CADI & Soft-leaved sedge & FACW & Sedge & yes & & & \\
\hline Carex echinata & CAEC & star sedge & NI & Sedge & yes & & & \\
\hline Carex lyngbyei & CALY & Lyngby sedge & OBL & Sedge & yes & & & \\
\hline Carex obnupta & CAOB & Slough sedge & OBL & Sedge & yes & & & \\
\hline Carex sp. & CASP & Carex & mixed & Sedge & yes & & & \\
\hline Carex stipata & CAST & Sawbeak sedge & FACW & Sedge & yes & & & \\
\hline Carex vesicaria & CAVE & $\begin{array}{l}\text { inflated sedge, blister } \\
\text { sedge }\end{array}$ & OBL & Sedge & yes & & & \\
\hline Castilleja ambigua & CAAM & $\begin{array}{l}\text { paint-brush owl-clover; } \\
\text { johnny-nip }\end{array}$ & FACW + & Herb & yes & & & ORCA \\
\hline Ceratophyllum demersum & CEDE & Coontail & OBL & Herb & yes & & SAV & \\
\hline Chamerion angustifolium & CHAN & Fireweed & FACU+ & Herb & yes & & $\begin{array}{l}\text { formerly Epilobium } \\
\text { angustifolium }\end{array}$ & EPAN \\
\hline
\end{tabular}


Table B.1. (contd)

\begin{tabular}{|c|c|c|c|c|c|c|c|c|}
\hline Scientific Name & Code & Common Name & $\begin{array}{l}\text { Wetland } \\
\text { Indicator } \\
\text { Status }\end{array}$ & Category & Native & $\begin{array}{l}\text { Invasive/ } \\
\text { Weedy }\end{array}$ & NOTES & $\begin{array}{c}\text { Previous } \\
\text { Species } \\
\text { Code }\end{array}$ \\
\hline Chenopodium album & CHAL & lambsquarters & FAC & Herb & no & yes & $\begin{array}{l}\text { possibly var. } \\
\text { striatum, which is } \\
\text { native }\end{array}$ & \\
\hline Cicuta douglasii & CIDO & Western water-hemlock & OBL & Herb & yes & yes & & \\
\hline Cirsium arvense var. horridum & CIAR & Canada thistle & FACU+ & Herb & no & yes & & \\
\hline Cirsium vulgare & CIVU & bull thistle & FACU & Herb & no & yes & & \\
\hline Claytonia sibirica & CLSI & $\begin{array}{l}\text { Candy flower; Siberian } \\
\text { spring beauty }\end{array}$ & FAC & Herb & yes & & & \\
\hline Comarum palustre & COPA & $\begin{array}{l}\text { purple marshlocks, marsh } \\
\text { cinquefoil }\end{array}$ & $\mathrm{OBL}$ & Herb & yes & & $\begin{array}{l}\text { formerly Potentilla } \\
\text { palustris }\end{array}$ & POPA \\
\hline Conium maculatum & COMA & Poison hemlock & FAC + & Herb & no & & & \\
\hline Convolvulus arvensis & COAR & $\begin{array}{l}\text { Morning glory; Field } \\
\text { bindweed }\end{array}$ & UPL & Herb & no & yes & & \\
\hline Coreopsis tinctoria & COTI & golden tickseed & FACU & Herb & yes & & & \\
\hline Cornus canadensis & COCA & bunchberry & FAC & Shrub & yes & & & \\
\hline Cornus sericea & COSE & Red-osier dogwood & FACW & Shrub & yes & & & COST \\
\hline Corylus cornuta & $\mathrm{COCO} 2$ & beaked hazelnut & FACU & Tree & yes & & & \\
\hline Cotula coronopifolia & $\mathrm{COCO}$ & common brassbuttons & FACW+ & Herb & no & & & \\
\hline Crataegus douglasii & CRDO & black hawthorn & FAC & Shrub & yes & & & \\
\hline Cyperus sp. & CYSP & flatsedge & & Herb & mixed & & & \\
\hline Cyperus strigosus & CYST & $\begin{array}{l}\text { Strawcolor flatsedge; } \\
\text { nutsedge }\end{array}$ & FACW & Sedge & yes & & & \\
\hline Dactylis glomerata & DAGL & Orchard-grass & FACU & Grass & no & & & \\
\hline Deschampsia cespitosa & DECE & Tufted hairgrass & FACW & Grass & yes & & & \\
\hline Digitaria ischaemum & DIIS & smooth crabgrass & FACU & Grass & no & & & \\
\hline Digitaria sanguinalis & DISA & hairy crabgrass & FACU & Grass & yes & & & \\
\hline Digitaria $s p$ & DISP & crabgrass & FACU & Grass & mixed & & & \\
\hline Distichlis spicata & DISP2 & saltgrass & FACW & Grass & yes & & & \\
\hline Eleocharis acicularis & ELAC & Needle spikerush & OBL & Sedge & yes & & & \\
\hline
\end{tabular}


Table B.1. (contd)

\begin{tabular}{|c|c|c|c|c|c|c|c|c|}
\hline Scientific Name & Code & Common Name & $\begin{array}{l}\text { Wetland } \\
\text { Indicator } \\
\text { Status }\end{array}$ & Category & Native & $\begin{array}{l}\text { Invasive/ } \\
\text { Weedy }\end{array}$ & NOTES & $\begin{array}{c}\text { Previous } \\
\text { Species } \\
\text { Code } \\
\end{array}$ \\
\hline Eleocharis ovata & ELOV & Ovoid spikerush & OBL & Sedge & yes & & & \\
\hline Eleocharis palustris & ELPA & Common spikerush & OBL & Sedge & yes & & & \\
\hline Eleocharis parvula & ELPAR & Dwarf spikerush & OBL & Sedge & yes & & & \\
\hline Eleocharis spp. & ELSP & Spikerush & OBL & Sedge & yes & & & \\
\hline Elodea canadensis & ELCA & Canada waterweed & OBL & Herb & yes & & SAV & \\
\hline Elodea nuttallii & ELNU & $\begin{array}{l}\text { Nuttall's waterweed, } \\
\text { western waterweed }\end{array}$ & OBL & Herb & yes & & SAV & \\
\hline Elymus repens & ELRE & Quackgrass & FAC- & Grass & no & yes & & \\
\hline Epilobium ciliatum & EPCI & Willow herb & FACW- & Herb & yes & & & \\
\hline Equisetum fluviatile & EQFL & Water horsetail & OBL & Fern & yes & & & \\
\hline Equisetum hyemale & EQHY & scouringrush horsetail & FACW & Fern & yes & & Lord Is 1 & \\
\hline Equisetum palustre & EQPA & marsh horsetail & FACW & Fern & yes & & & \\
\hline Equisetum spp. & EQSP & Horsetail & mixed & Fern & yes & & & \\
\hline Equisetum telmateia & EQTE & giant horsetail & FACW & Fern & yes & & & \\
\hline Euthamia occidentalis & EUOC & western goldentop & $\mathrm{FACW}^{*}$ & Herb & yes & & & \\
\hline Frangula purshiana & FRPU & Cascara & FAC- & Tree & yes & & $\begin{array}{l}\text { formerly Rhamnus } \\
\text { purshiana }\end{array}$ & RHPU \\
\hline Fraxinus latifolia & FRLA & Oregon ash & FACW & Tree & yes & & & \\
\hline Fucus distichus & FUDI & Rockweed & OBL & Algae & yes & & & \\
\hline Galium aparine & GAAP & Cleavers bedstraw & FACU & Herb & yes & yes & hairy nutlets & \\
\hline Galium spp & GASP & $\begin{array}{l}\text { Pacific bedstraw; } \\
\text { cleavers; small bedstraw }\end{array}$ & mixed & Herb & yes & & & \\
\hline Galium trifidum & GATR3 & small bedstraw & $\mathrm{FACW}+$ & Herb & yes & & $\begin{array}{l}\text { smooth nutlets, } \\
\text { smaller than var. } \\
\text { pacificum }\end{array}$ & \\
\hline $\begin{array}{l}\text { Galium trifidum var. pacificum; } \\
\text { Galium trifidum L. spp. columbianum }\end{array}$ & GATR & Pacific bedstraw & FACW & Herb & yes & & smooth nutlets & \\
\hline Galium triflorum & GATR2 & fragrant bedstraw & FACU & Herb & yes & & $\begin{array}{l}\text { hairy nutlets, usually } \\
\text { partial shade }\end{array}$ & \\
\hline
\end{tabular}


Table B.1. (contd)

\begin{tabular}{|c|c|c|c|c|c|c|c|c|}
\hline Scientific Name & Code & Common Name & $\begin{array}{c}\text { Wetland } \\
\text { Indicator } \\
\text { Status }\end{array}$ & Category & Native & $\begin{array}{l}\text { Invasive/ } \\
\text { Weedy }\end{array}$ & NOTES & $\begin{array}{c}\text { Previous } \\
\text { Species } \\
\text { Code } \\
\end{array}$ \\
\hline Gaultheria shallon & GASH & Salal & FACU & Shrub & yes & & & \\
\hline Geum macrophyllum & GEMA & Largeleaf avens & FACW- & Herb & yes & & & \\
\hline Glaux maritima & GLMA & sea milkwort & FACW + & Herb & yes & & & \\
\hline Glechoma hederacea & GLHE & Creeping Charlie & FACU+ & Herb & no & yes & & \\
\hline Glyceria grandis & GLGR & American mannagrass & OBL & Grass & yes & & & \\
\hline Glyceria striata & GLST & Fowl mannagrass & OBL & Grass & yes & & formerly G. elata & GLEL \\
\hline Gnaphalium uliginosum & GNUL & Marsh cudweed & FAC + & Herb & no & & & \\
\hline Gratiola ebracteata & GREB & bractless hedgehyssop & OBL & Herb & yes & & & \\
\hline Gratiola neglecta & GRNE & American Hedge-hyssop & OBL & Herb & yes & & & \\
\hline Hedera helix & HEHE & English ivy & UPL & Herb & no & yes & & \\
\hline Helenium autumnale & HEAU & common sneezeweed & FACW & Herb & yes & & & \\
\hline Heracleum maximum & HEMA & Cow-parsnip & $\mathrm{FAC}+$ & Herb & yes & & $\begin{array}{l}\text { formerly Heracleum } \\
\text { lanatum }\end{array}$ & HELA \\
\hline Holcus lanatus & HOLA & Common velvetgrass & FAC & Grass & no & & & \\
\hline Hordeum brachyantherum & HOBR & Meadow barley & FACW- & Grass & yes & & & \\
\hline Hydrocotyle ranunculoides & HYRA2 & Water pennywort & OBL & Herb & yes & & & \\
\hline Hypericum scouleri & HYSC & Western St. Johns wort & FAC & Herb & yes & & $\begin{array}{l}\text { also called } \\
\text { Hypericum formosum }\end{array}$ & HYFO \\
\hline Ilex aquifolium & ILAQ & English holly & UPL & Tree & no & & & \\
\hline Ilex sp. & ILSP & Holly & UPL & Tree & no & & & \\
\hline $\begin{array}{l}\text { Impatiens capensis,Impatiens noli- } \\
\text { tangere }\end{array}$ & IMSP & $\begin{array}{l}\text { Spotted touch-me-not, } \\
\text { Common touch-me-not }\end{array}$ & FACW & Herb & yes & & & \\
\hline Iris pseudacorus & IRPS & Yellow iris & OBL & Herb & no & & & \\
\hline Juncus acuminatus & JUAC & Tapertip rush & OBL & Rush & yes & & & \\
\hline Juncus arcticus Wild. ssp. littoralis & JUAR & mountain rush & No & Rush & yes & & $\begin{array}{l}\text { formerly Juncus } \\
\text { balticus, Baltic rush }\end{array}$ & JUBA \\
\hline Juncus bufonius & JUBU & Toad rush & FACW & Rush & yes & & & \\
\hline Juncus effusus & JUEF & Soft rush & FACW & Rush & mixed & & & \\
\hline Juncus ensifolius & JUEN & Daggerleaf rush & FACW & Rush & yes & & & \\
\hline
\end{tabular}


Table B.1. (contd)

\begin{tabular}{|c|c|c|c|c|c|c|c|c|}
\hline Scientific Name & Code & Common Name & $\begin{array}{c}\text { Wetland } \\
\text { Indicator } \\
\text { Status }\end{array}$ & Category & Native & $\begin{array}{c}\text { Invasive/ } \\
\text { Weedy }\end{array}$ & NOTES & $\begin{array}{c}\text { Previous } \\
\text { Species } \\
\text { Code }\end{array}$ \\
\hline Juncus falcatus & JUFA & Sickleleaf rush & FACW- & Rush & yes & & & \\
\hline Juncus gerardii & JUGE & saltmeadow rush & FACW + & Rush & yes & & & \\
\hline Juncus nevadensis & JUNE & Sierra rush & FACW & Rush & yes & & & \\
\hline Juncus oxymeris & JUOX & Pointed rush & FACW + & Rush & yes & & & \\
\hline Juncus spp. & JUSP & Rush & mixed & Rush & mixed & & & \\
\hline Juncus supiniformis & JUSU & Spreading rush & OBL & Rush & yes & & & \\
\hline Juncus tenuis & JUTE & slender rush, poverty rush & FACW- & Rush & yes & & & \\
\hline Lathyrus palustris & LAPA & Marsh peavine & OBL & Herb & yes & & & \\
\hline Leersia oryzoides & LEOR & Rice cutgrass & OBL & Grass & yes & & & \\
\hline Lemna minor & LEMI & Duckweed & OBL & Herb & yes & & & \\
\hline Leucanthemum vulgare & LEVU & oxeye daisy & UPL & Herb & no & yes & & \\
\hline Leymus mollis & LEMO & American dunegrass & UPL & Grass & yes & & & \\
\hline Lilaeopsis occidentalis & LIOC & Western lilaeopsis & OBL & Herb & yes & & & \\
\hline Limosella aquatica & LIAQ & Water mudwort & OBL & Herb & yes & & & \\
\hline Lonicera involucrata & LOIN & Black twinberry & $\mathrm{FAC}+$ & Shrub & yes & & & \\
\hline Lotus corniculatus & LOCO & Birdsfoot trefoil & $\mathrm{FAC}$ & Herb & no & & & \\
\hline Ludwigia palustris & LUPA & False loosestrife & OBL & Herb & yes & & & \\
\hline Lupinus polyphyllus & LUPO & Large-leaved lupine & $\mathrm{FAC}+$ & Herb & yes & & & \\
\hline Lycopus americanus & LYAM2 & $\begin{array}{l}\text { American water } \\
\text { horehound }\end{array}$ & OBL & Herb & yes & & & \\
\hline Lycopus sp. & LYSP & Bugleweed; horehound & OBL & Herb & yes & & & \\
\hline Lycopus uniflorus & LYUN & Northern bugleweed & OBL & Herb & yes & & & \\
\hline Lysichiton americanus & LYAM & Skunk cabbage & OBL & Herb & yes & & & \\
\hline Lysimachia nummularia & LYNU & $\begin{array}{l}\text { Moneywort, Creeping } \\
\text { Jenny }\end{array}$ & FACW & Herb & no & & & \\
\hline Lythrum salicaria & LYSA & Purple loosestrife & FACW+ & Herb & no & yes & & \\
\hline Madia sativa & MASA & coast tarweed & UPL & Herb & yes & & & \\
\hline Maianthemum dilatatum & MADI & Wild lily-of-the-valley & FAC & Herb & yes & & & \\
\hline
\end{tabular}


Table B.1. (contd)

\begin{tabular}{|c|c|c|c|c|c|c|c|c|}
\hline Scientific Name & Code & Common Name & $\begin{array}{c}\text { Wetland } \\
\text { Indicator } \\
\text { Status }\end{array}$ & Category & Native & $\begin{array}{c}\text { Invasive/ } \\
\text { Weedy }\end{array}$ & NOTES & $\begin{array}{c}\text { Previous } \\
\text { Species } \\
\text { Code }\end{array}$ \\
\hline Maianthemum racemosum & MARA & $\begin{array}{l}\text { Large false lily of the } \\
\text { valley }\end{array}$ & UPL & Herb & yes & & $\begin{array}{l}\text { formerly Smilacina } \\
\text { racemosa }\end{array}$ & SMRA \\
\hline Malus fusca & MAFU & Pacific crab apple & FACW & Tree & yes & & & \\
\hline Marchantia polymorpha & MAPO & Lung liverwort & na & NV & yes & & & \\
\hline Mentha arvensis & MEAR & wild mint & FACW- & Herb & yes & & pointy serrations & \\
\hline Mentha spicata $L$. & MESP3 & spearmint & OBL & Herb & no & & rounded serrations & \\
\hline Mentha spp. & MESP & $\begin{array}{l}\text { Mint (field mint, } \\
\text { spearmint) }\end{array}$ & mixed & Herb & mixed & & & \\
\hline Mimulus alsinoides & MIAL & $\begin{array}{l}\text { Chickweed monkey- } \\
\text { flower }\end{array}$ & OBL & Herb & yes & & & \\
\hline Mimulus guttatus & MIGU & Yellow monkeyflower & OBL & Herb & yes & & & \\
\hline Mimulus lewisii & MILE & $\begin{array}{l}\text { great purple monkey } \\
\text { flower }\end{array}$ & FACW + & Herb & yes & & & \\
\hline Mimulus ringens & MIRI & Allegheny monkeyflower & OBL & Herb & yes & & & \\
\hline Mitella trifida & MITR & Three-toothed mitrewort & na & Herb & yes & & & \\
\hline Myosotis laxa & MYLA & Small forget-me-not & OBL & Herb & yes & & & \\
\hline Myosotis laxa, M. scorpioides & MYSP & $\begin{array}{l}\text { Small forget-me-not, } \\
\text { Common forget-me-not }\end{array}$ & mixed & Herb & mixed & & & \\
\hline Myosotis scorpioides & MYSC & Common forget-me-not & FACW & Herb & no & & & \\
\hline Myriophyllum aquaticum & MYAQ & Parrot-feather milfoil & OBL & Herb & no & yes & SAV & \\
\hline Myriophyllum hippuroides & MYHI & western milfoil & OBL & Herb & yes & & SAV & \\
\hline Myriophyllum sibiricum & MYSI & $\begin{array}{l}\text { northern milfoil, short } \\
\text { spike milfoil }\end{array}$ & OBL & Herb & yes & & SAV & \\
\hline Myriophyllum spicatum & MYSP3 & Eurasian water milfoil & OBL & Herb & no & yes & SAV & \\
\hline Myriophyllum spp. & MYSP2 & Milfoil & OBL & Herb & mixed & & & \\
\hline Nuphar lutea & NULU & Yellow pond-lily & OBL & Herb & yes & & & \\
\hline Oemleria cerasiformis & OECE & Indian-plum & FACU & Shrub & yes & & & \\
\hline Oenanthe sarmentosa & OESA & Water parsley & OBL & Herb & yes & & & \\
\hline Oxalis oregana & OXOR & Redwood sorrel & UPL & Herb & yes & & & \\
\hline
\end{tabular}


Table B.1. (contd)

\begin{tabular}{|c|c|c|c|c|c|c|c|c|}
\hline Scientific Name & Code & Common Name & $\begin{array}{l}\text { Wetland } \\
\text { Indicator } \\
\text { Status } \\
\end{array}$ & Category & Native & $\begin{array}{l}\text { Invasive/ } \\
\text { Weedy }\end{array}$ & NOTES & $\begin{array}{l}\text { Previous } \\
\text { Species } \\
\text { Code } \\
\end{array}$ \\
\hline Panicum capillare & PACA & witchgrass & FACU+ & Grass & yes & & & \\
\hline $\begin{array}{l}\text { Panicum occidentale/Dichanthelium } \\
\text { acuminatum }\end{array}$ & PAOC & western panicgrass & FACW & Grass & yes & & & \\
\hline Parentucellia viscosa & PAVI & Yellow parentucellia & FAC- & Herb & no & & & \\
\hline Paspalum distichum & PADI & Knotgrass & FACW & Grass & yes & & & \\
\hline Pellia neesiana & PENE & Ring pellia & & Liverwort & yes & & & \\
\hline Phacelia hastata & PHHA & silver-leaf phacelia & UPL & Herb & yes & & & \\
\hline Phalaris arundinacea & PHAR & Reed canary-grass & FACW & Grass & no & yes & & \\
\hline Physocarpus capitatus & PHCA & Pacific ninebark & FACW- & Shrub & yes & & & \\
\hline Picea sitchensis & PISI & Sitka spruce & FAC & Tree & yes & & & \\
\hline Plantago lanceolata var. lanceolata & PLLA & Rib plantain & FAC & Herb & no & & & \\
\hline Plantago major & PLMA & common plantain & FACU+ & Herb & no & & & \\
\hline Platanthera dilatata & PLDI & white bog orchid & FACW + & Herb & yes & & & \\
\hline Роа аппиа & POAN2 & annual bluegrass & FAC & Grass & no & & & \\
\hline Polygonum amphibium & POAM & $\begin{array}{l}\text { water ladysthumb, water } \\
\text { smartweed }\end{array}$ & OBL & Herb & yes & & & \\
\hline $\begin{array}{l}\text { Polygonum hydropiper, } P . \\
\text { hydropiperoides }\end{array}$ & POHY & $\begin{array}{l}\text { Waterpepper, mild } \\
\text { waterpepper, swamp } \\
\text { smartweed }\end{array}$ & OBL & Herb & mixed & & & \\
\hline Polygonum lapathifolium & POLA & curly top knotweed & FACW & Herb & yes & & & \\
\hline Polygonum persicaria & POPE & Spotted ladysthumb & FACW & Herb & no & yes & & \\
\hline Polygonum sp. & POSP & Knotweed, Smartweed & mixed & Herb & mixed & & & \\
\hline Polypodium glycyrrhiza & POGL & Licorice fern & FACU & Fern & yes & & & \\
\hline Polystichum munitum & POMU & Sword fern & FACU & Fern & yes & & & \\
\hline Populus balsamifera & POBA & black cottonwood & FAC & Tree & yes & & & \\
\hline Potamogeton crispus & POCR & Curly leaf pondweed & OBL & Herb & no & yes & SAV & \\
\hline Potamogeton natans & PONA & Floating-leaved pondweed & OBL & Herb & yes & & SAV & \\
\hline Potamogeton pusillus & POPU & Small pondweed & OBL & Herb & yes & & SAV & \\
\hline Potamogeton richardsonii & PORI & Richardson's pondweed & OBL & Herb & yes & & SAV & \\
\hline
\end{tabular}


Table B.1. (contd)

\begin{tabular}{|c|c|c|c|c|c|c|c|c|}
\hline Scientific Name & Code & Common Name & $\begin{array}{c}\text { Wetland } \\
\text { Indicator } \\
\text { Status } \\
\end{array}$ & Category & Native & $\begin{array}{l}\text { Invasive/ } \\
\text { Weedy }\end{array}$ & NOTES & $\begin{array}{c}\text { Previous } \\
\text { Species } \\
\text { Code } \\
\end{array}$ \\
\hline Potamogeton $s p$. & POSP2 & Pondweed & OBL & Herb & mixed & & & \\
\hline Potamogeton zosteriformis & $\mathrm{POZO}$ & Eelgrass pondweed & OBL & Herb & yes & & SAV & \\
\hline $\begin{array}{l}\text { Potentilla anserina ssp. } \\
\text { Pacifica/Argentina egedii ssp. Egedii }\end{array}$ & POAN & Pacific silverweed & OBL & Herb & yes & & $\begin{array}{l}\text { also known as } \\
\text { Argentina egedii spp. } \\
\text { Egedii }\end{array}$ & \\
\hline Prunella vulgaris & PRVU & Self heal & FACU+ & Herb & yes & & & \\
\hline Prunus emarginata & PREM & Bitter cherry & FACU & Tree & yes & & & \\
\hline Pseudognaphalium canescens & PSCA & $\begin{array}{l}\text { Slender cudweed; } \\
\text { Wright's cudweed }\end{array}$ & UPL & Herb & yes & & $\begin{array}{l}\text { formerly Gnaphalium } \\
\text { microcephalum }\end{array}$ & GNMI \\
\hline Pteridium aquilinum & PTAQ & Bracken fern & FACU & Fern & yes & & & \\
\hline Puccinellia pumila & PUPU & dwarf alkaligrass & FACW + & Herb & yes & & & \\
\hline Ranunculus cymbalaria & RACY & Alkali buttercup & OBL & Herb & yes & & & \\
\hline Ranunculus flammula & RAFL & Small creeping buttercup & FACW & Herb & yes & & & \\
\hline Ranunculus repens & RARE & Creeping buttercup & FACW & Herb & no & & & \\
\hline Ranunculus sceleratus & RASC & Celery-leaved buttercup & OBL & Herb & yes & & & \\
\hline Ranunculus uncinatus & RAUN & Woodland buttercup & FAC- & Herb & yes & & & \\
\hline Ribes bracteosum & RIBR & Stink currant & FAC & Shrub & yes & & & \\
\hline Ribes divaricatum & RIDI & $\begin{array}{l}\text { Wax currant, coast black } \\
\text { currant }\end{array}$ & FAC & Shrub & yes & & & \\
\hline Ribes lacustre & RILA & Swamp gooseberry & FAC + & Shrub & yes & & & \\
\hline Riccia fluitans & RIFL & Liverwort & na & Liverwort & yes & & & \\
\hline Ricciocarpos natans & RINA & Purple fringed liverwort & na & Liverwort & yes & & & \\
\hline Rorippa calycina, R.curvisiliqua & ROSP & Yellow cress & mixed & Herb & yes & & & \\
\hline Rorippa columbiae & $\mathrm{ROCO}$ & Columbian yellowcress & OBL & Herb & yes & & $\begin{array}{l}\text { Threatened in } \\
\text { Washington state }\end{array}$ & ROCA \\
\hline Rorippa curvisiliqua & ROCU & curvepod yellow cress & OBL & Herb & yes & & & \\
\hline $\begin{array}{l}\text { Rorippa nasturtium- } \\
\text { aquaticum/Nasturtium officinale }\end{array}$ & RONA & Watercress & OBL & Herb & no & & & \\
\hline Rorippa palustris & ROPA & Marsh yellow-cress & OBL & Herb & yes & & & \\
\hline
\end{tabular}


Table B.1. (contd)

\begin{tabular}{|c|c|c|c|c|c|c|c|c|}
\hline Scientific Name & Code & Common Name & $\begin{array}{c}\text { Wetland } \\
\text { Indicator } \\
\text { Status }\end{array}$ & Category & Native & $\begin{array}{l}\text { Invasive/ } \\
\text { Weedy }\end{array}$ & NOTES & $\begin{array}{c}\text { Previous } \\
\text { Species } \\
\text { Code } \\
\end{array}$ \\
\hline Rosa nutkana & RONU & Nootka rose & FAC & Shrub & yes & & & \\
\hline Rosa pisocarpa & ROPI & $\begin{array}{l}\text { Clustered wild rose, } \\
\text { peafruit rose, swamp rose }\end{array}$ & $\mathrm{FAC}$ & Shrub & yes & & & \\
\hline Rubus armeniacus & RUAR & Himalayan blackberry & FACU & Shrub & no & & $\begin{array}{l}\text { formerly Rubus } \\
\text { discolor }\end{array}$ & RUDI \\
\hline Rubus laciniatus & RULA & Evergreen blackberry & FACU+ & Shrub & no & & & \\
\hline Rubus parviflorus & RUPA & Thimbleberry & FAC- & Shrub & yes & & & \\
\hline Rubus spectabilis & RUSP & Salmonberry & FAC + & Shrub & yes & & & \\
\hline Rubus ursinus & RUUR & Trailing blackberry & FACU & Shrub & yes & & & \\
\hline Rumex acetosella & RUAC & common sheep sorrel & FACU+ & Herb & no & yes & & \\
\hline Rumex aquaticus & RUAQ & Western dock & FACW + & Herb & yes & & $\begin{array}{l}\text { formerly Rumex } \\
\text { occidentalis }\end{array}$ & RUOC \\
\hline Rumex crispus & RUCR & Curly dock & FAC + & Herb & no & & & \\
\hline Rumex maritimus & RUMA & $\begin{array}{l}\text { Golden dock, seaside } \\
\text { dock }\end{array}$ & FACW + & Herb & yes & & & \\
\hline Ruppia maritima & RUMA2 & Widgeongrass & OBL & Herb & yes & & SAV & \\
\hline Sagittaria latifolia & SALA & Wapato & OBL & Herb & yes & & & \\
\hline Salicornia depressa & SADE & pickleweed & OBL & Herb & yes & & $\begin{array}{l}\text { formerly Salicornia } \\
\text { virginica }\end{array}$ & SAVI \\
\hline Salix fluviatilis & SAFL & $\begin{array}{l}\text { Columbia River willow, } \\
\text { river willow }\end{array}$ & OBL & Shrub & yes & & & \\
\hline Salix lucida & SALU & Pacific willow & FACW + & Shrub & yes & & & \\
\hline Salix sitchensis & SASI & Sitka willow & FACW & Shrub & yes & & & \\
\hline Salix spp. & SASP & Willow & mixed & Shrub & yes & & & \\
\hline Sambucus racemosa & SARA & Red elderberry & FACU & Shrub & yes & & & \\
\hline Schoenoplectus acutus & SCAC & Hardstem bulrush, tule & OBL & Sedge & yes & & $\begin{array}{l}\text { formerly Scirpus } \\
\text { acutus }\end{array}$ & SCAC \\
\hline Schoenoplectus americanus & SCAM & $\begin{array}{l}\text { American bulrush, } \\
\text { threesquare bulrush }\end{array}$ & OBL & Sedge & yes & & $\begin{array}{l}\text { formerly Scirpus } \\
\text { americanus }\end{array}$ & SCAM \\
\hline
\end{tabular}


Table B.1. (contd)

\begin{tabular}{|c|c|c|c|c|c|c|c|c|}
\hline Scientific Name & Code & Common Name & $\begin{array}{c}\text { Wetland } \\
\text { Indicator } \\
\text { Status }\end{array}$ & Category & Native & $\begin{array}{l}\text { Invasive/ } \\
\text { Weedy }\end{array}$ & NOTES & $\begin{array}{c}\text { Previous } \\
\text { Species } \\
\text { Code }\end{array}$ \\
\hline Schoenoplectus maritimus & SCMA & Seacoast bulrush & OBL & Sedge & yes & & $\begin{array}{l}\text { formerly Scirpus } \\
\text { maritimus }\end{array}$ & SCMA \\
\hline Schoenoplectus spp. & SCSP & hybrid sedge & OBL & Sedge & mixed & & $\begin{array}{l}\text { used when spp } \\
\text { appears to have } \\
\text { hybridized or has no } \\
\text { identifying features }\end{array}$ & \\
\hline Schoenoplectus tabernaemontani & SCTA & Softstem bulrush, tule & OBL & Sedge & Yes & & $\begin{array}{l}\text { formerly Scirpus } \\
\text { lacustris }\end{array}$ & SCLA \\
\hline Schoenoplectus triqueter & SCTR & Threesquare tule & OBL & Sedge & no & & $\begin{array}{l}\text { formerly Scirpus } \\
\text { triqueter }\end{array}$ & SCTR \\
\hline Scirpus cyperinus & SCCY & woolly sedge & OBL & Sedge & yes & & & \\
\hline Scirpus microcarpus & SCMI & Small-fruited bulrush & OBL & Sedge & yes & & & \\
\hline Scrophularia lanceolata & SCLA & Lance-leaf figwort & FAC & Herb & yes & & formerly SCLA2 & SCLA2 \\
\hline Sium suave & SISU & Hemlock waterparsnip & OBL & Herb & yes & & & \\
\hline Solanum dulcamara & SODU & Bittersweet nightshade & $\mathrm{FAC}+$ & Herb & no & & & \\
\hline Solidago canadensis & SOCA & Canada goldenrod & FACU & Herb & yes & & & \\
\hline Sparganium angustifolium & SPAN & Narrowleaf burreed & OBL & Herb & yes & & & SPEM \\
\hline Spiraea douglasii & SPDO & Douglas spiraea & FACW & Shrub & yes & & & \\
\hline Stachys cooleyae & STCO & Cooley's hedge-nettle & FACW & Herb & yes & & & \\
\hline Stellaria crispa & STCR & Curled starwort & $\mathrm{FAC}+$ & Herb & yes & & & \\
\hline Stellaria longifolia & STLO & Longleaf starwort & FACW & Herb & yes & & & \\
\hline Symphoricarpos albus & SYAL & Common snowberry & FACU & Shrub & yes & & & \\
\hline Symphyotrichum subspicatum & SYSU & Douglas aster & FACW & Herb & yes & & $\begin{array}{l}\text { formerly Aster } \\
\text { subspicatus }\end{array}$ & ASSU \\
\hline Taraxacum officinale & TAOF & Common dandelion & FACU & Herb & no & & & \\
\hline Tellima grandiflora & TEGR & Fringe cup & UPL & Herb & yes & & & \\
\hline Thuja plicata & THPL & Western redcedar & FAC & Tree & yes & & & \\
\hline Tiarella trifoliata & TITR & Foamflower & FAC- & Herb & yes & & & \\
\hline Tolmiea menziesii & TOME & Piggy-back plant & FAC & Herb & yes & & & \\
\hline
\end{tabular}


Table B.1. (contd)

\begin{tabular}{|c|c|c|c|c|c|c|c|c|}
\hline Scientific Name & Code & Common Name & $\begin{array}{c}\text { Wetland } \\
\text { Indicator } \\
\text { Status }\end{array}$ & Category & Native & $\begin{array}{c}\text { Invasive/ } \\
\text { Weedy }\end{array}$ & NOTES & $\begin{array}{c}\text { Previous } \\
\text { Species } \\
\text { Code }\end{array}$ \\
\hline Toxicodendron diversilobum & TODI & Pacific poison oak & UPL & Shrub & yes & & $\begin{array}{l}\text { upland area of Water } \\
\text { Resources Center }\end{array}$ & \\
\hline Trifolium arvense & TRAR & rabbitfoot clover & UPL & Herb & no & yes & & \\
\hline $\begin{array}{l}\text { Trifolium pratense, } T \text {. repens, } T \text {. } \\
\text { dubium }\end{array}$ & TRSP & $\begin{array}{l}\text { Red clover, white clover, } \\
\text { small hop-clover }\end{array}$ & mixed & Herb & no & & & \\
\hline Trifolium wormskioldii & TRWO & Springbank clover & FACW + & Herb & yes & & & \\
\hline Triglochin maritima & TRMA & Seaside arrowgrass & OBL & $\begin{array}{l}\text { Arrow- } \\
\text { grass }\end{array}$ & yes & & & \\
\hline Typha angustifolia & TYAN & Narrowleaf cattail & OBL & Herb & no & & & \\
\hline Typha angustifolia, T. latifolia & TYSP & $\begin{array}{l}\text { Narrowleaf cattail, } \\
\text { common cattail }\end{array}$ & OBL & Herb & mixed & & & \\
\hline Typha latifolia & TYLA & Common cattail & OBL & Herb & yes & & & \\
\hline Urtica dioica & URDI & Stinging Nettle & $\mathrm{FAC}+$ & Herb & yes & & & \\
\hline Vaccinium parvifolium & VAPA & Red huckleberry & FACU & Shrub & yes & & & \\
\hline Veratrum californicum & VECA & California false hellebore & FACW+ & Herb & yes & & & \\
\hline Verbascum thapsus & VETH & Common mullein & UPL & Herb & no & & $\begin{array}{l}\text { upland area of Water } \\
\text { Resources Center }\end{array}$ & \\
\hline Veronica americana & VEAM & American speedwell & OBL & Herb & yes & & & \\
\hline Veronica anagallis-aquatica & VEAN & water speedwell & OBL & Herb & yes & & & \\
\hline Veronica scutellata & VESC & marsh speedwell & OBL & Herb & yes & & & \\
\hline Veronica spp. & VESP & speedwell & OBL & Herb & yes & & & \\
\hline Viburnum edule & VIED & Highbush cranberry & FACW & Shrub & yes & & & \\
\hline Vicia americana & VIAM & American vetch & FAC & Herb & yes & & & \\
\hline Vicia spp & VISP & Vetch & mixed & Herb & mixed & & & \\
\hline Wolffia spp. & WOSP & Watermeal & OBL & Herb & yes & & & \\
\hline Xanthium strumarium & XAST & rough cocklebur & FAC & Herb & yes & & & \\
\hline Zannichellia palustris & ZAPA & horned pondweed & OBL & Herb & yes & & SAV & \\
\hline Zostera japonica & ZOJA & Japanese eelgrass & OBL & Herb & no & & & NAJA \\
\hline
\end{tabular}


Table B.2. Plant species observed by researchers other than PNNL during restoration monitoring that were not already included in the PNNL species list (Table B.1).

\begin{tabular}{|c|c|c|c|c|c|c|c|c|}
\hline Scientific Name & Code & Common Name & $\begin{array}{c}\text { Wetland } \\
\text { Indicator } \\
\text { Status }\end{array}$ & $\begin{array}{c}\text { Categor } \\
\mathrm{y}\end{array}$ & Native & Invasive/Weedy & Notes & $\begin{array}{c}\text { Previous } \\
\text { Species } \\
\text { Code }\end{array}$ \\
\hline \multicolumn{9}{|c|}{ Species observed at restoration sites } \\
\hline Acer macrophyllum & ACMA & Bigleaf maple & FACU & Tree & yes & & & \\
\hline Acer sp. & ACSP & maple & mixed & mixed & yes & & & \\
\hline Achillea millefolium & ACMI & common yarrow & FACU & Herb & NI & & & \\
\hline Aira praecox & AIPR & yellow hairgrass & NA & Grass & no & & & \\
\hline Alisma sp. & ALSP & water plantain & OBL & Herb & mixed & & & \\
\hline Alopecurus geniculatus & ALGE & $\begin{array}{l}\text { water foxtail, water } \\
\text { fescue }\end{array}$ & OBL & Grass & no & & & \\
\hline Alopecurus sp. & ALSP2 & foxtail & mixed & Grass & mixed & & & \\
\hline Amsinckia sp. & AMSP & fiddlehead & mixed & Herb & yes & & & \\
\hline Bidens sp. & BISP & beggartick & mixed & Herb & mixed & & & \\
\hline Bromus hordeaceus & BRHO & soft brome & UPL & Grass & no & & & \\
\hline Bromus sitchensis & BRSI & Alaska brome & NA & Grass & yes & & & \\
\hline Callitriche sp. & CASP3 & water-starwort & OBL & Herb & mixed & & & \\
\hline Callitriche stagnalis & CAST2 & pond water-starwort & OBL & Herb & no & & & \\
\hline Cichorium intybus & $\mathrm{CIDO} 2$ & chicory & NA & Herb & no & & & \\
\hline Cirsium sp. & CISP & Cirsium species & mixed & Herb & mixed & & & \\
\hline Collomia grandiflora & COGR & Grand collomia & NA & Herb & yes & & & \\
\hline Conyza canadensis & COCA2 & Canadian horseweed & FACU & Herb & yes & & & \\
\hline
\end{tabular}


Table B.2. (contd)

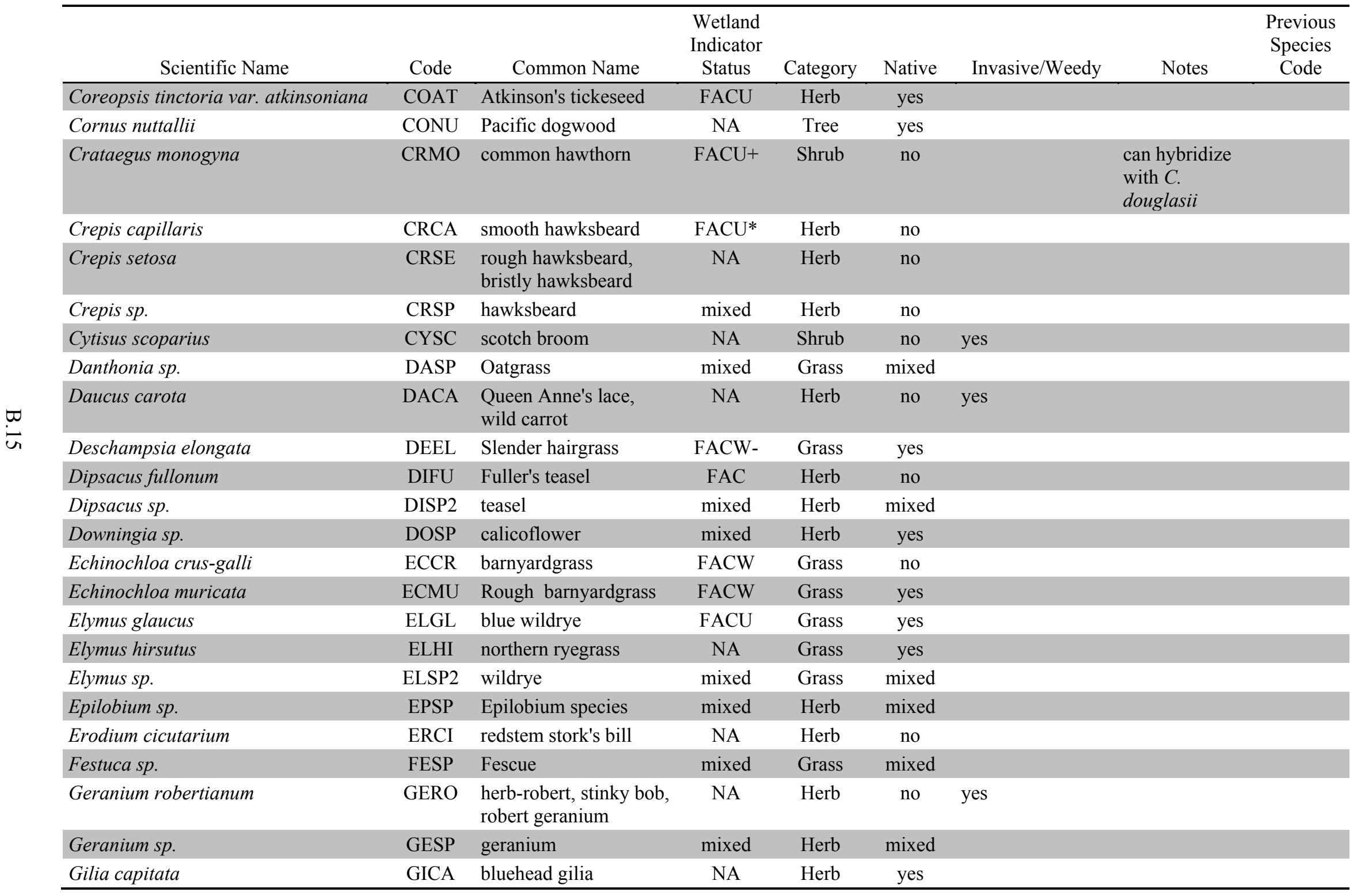


Table B.2. (contd)

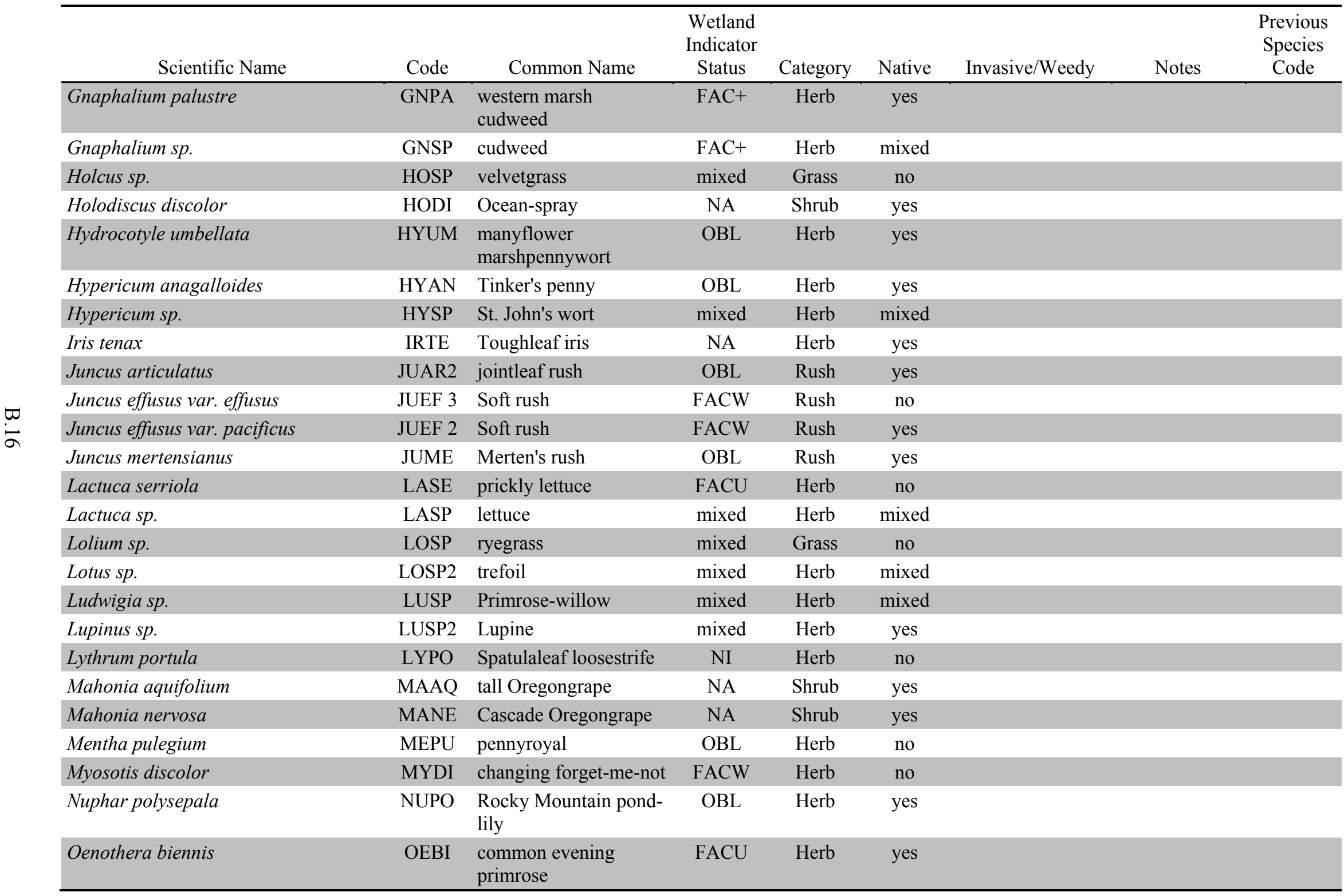


Table B.2. (contd)

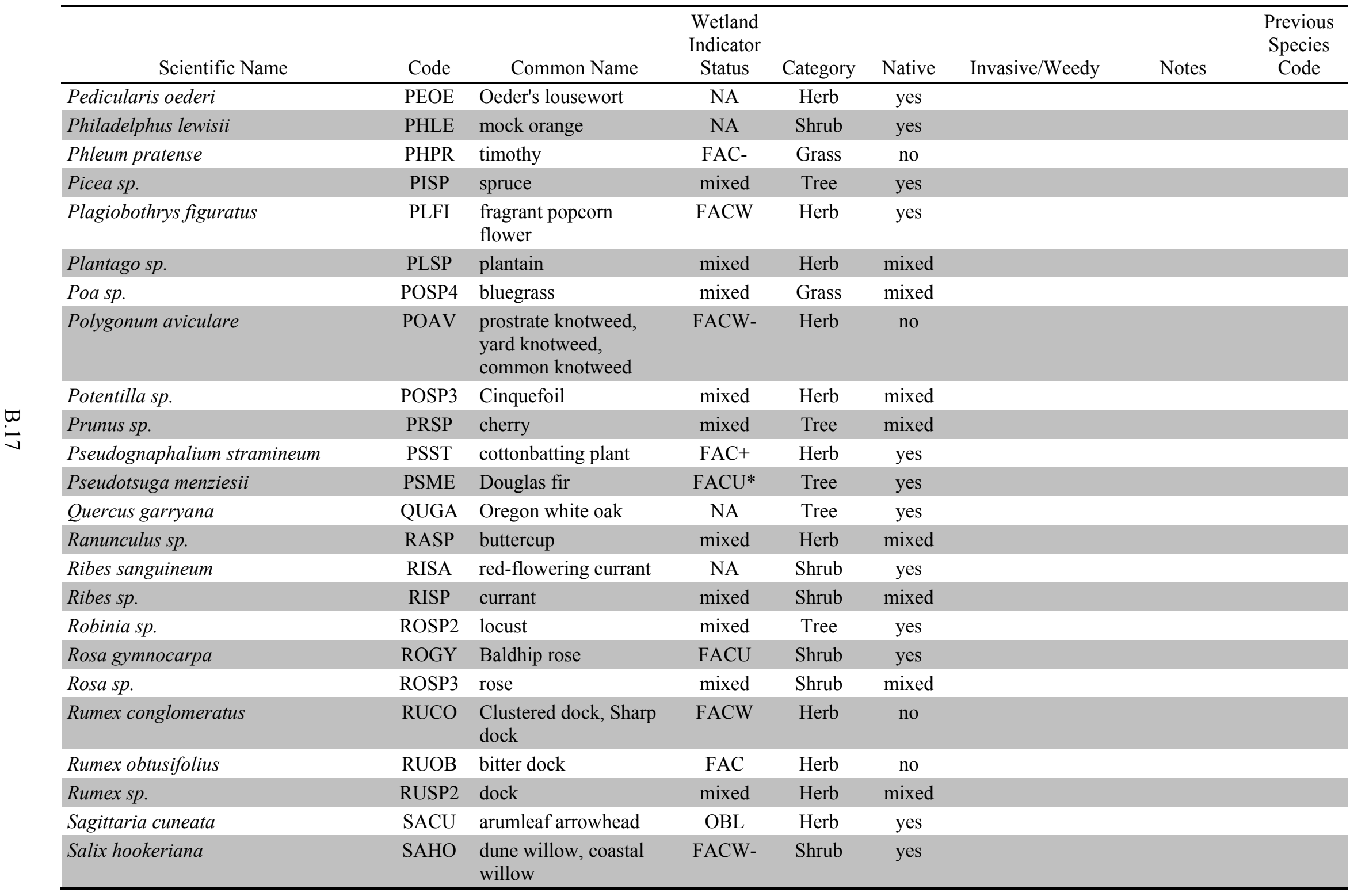


Table B.2. (contd)

\begin{tabular}{|c|c|c|c|c|c|c|c|c|}
\hline Scientific Name & Code & Common Name & $\begin{array}{l}\text { Wetland } \\
\text { Indicator } \\
\text { Status }\end{array}$ & Category & Native & Invasive/Weedy & Notes & $\begin{array}{c}\text { Previous } \\
\text { Species } \\
\text { Code }\end{array}$ \\
\hline Salix piperi & SAPI & Piper willow & FACW- & Shrub & yes & & & \\
\hline Sambucus cerulea & SACE & blue elderberry & FACU & Shrub & yes & & & \\
\hline Sambucus sp. & SASP2 & elderberry & FACU & Shrub & yes & & & \\
\hline Schedonorus phoenix & $\mathrm{SCPH}$ & tall fescue & FAC- & Grass & no & & & \\
\hline Senecio jacobaea & SEJA & $\begin{array}{l}\text { Stinking willie, tansy } \\
\text { ragwort }\end{array}$ & FACU & Herb & yes & yes & & \\
\hline Senecio sp. & SESP & ragwort & mixed & Herb & mixed & & & \\
\hline Sisymbrium officinale & SIOF & hedgemustard & NA & Herb & no & & & \\
\hline Solanum nigrum & SONI & Black nightshade & FACU & Herb & no & & & \\
\hline Solanum sp. & SOSP & Nightshade & mixed & Herb & mixed & & & \\
\hline Tanacetum sp. & TASP & tansy & mixed & Herb & mixed & & & \\
\hline Tanacetum vulgare & TAVU & common tansy & NI & Herb & no & yes & & \\
\hline Trifolium grandiflorum & TRGR & large-flower hop clover & NA & Herb & NA & & & \\
\hline Trifolium repens & TRRE & white clover & FAC* & Herb & no & & & \\
\hline Triticum $s p$. & TRSP2 & wheat & NA & Grass & no & & & \\
\hline Tsuga heterophylla & TSHE & Western hemlock & FACU- & Tree & yes & & & \\
\hline Verbascum blattaria & VEBL & moth mullein & UPL & Herb & no & & & \\
\hline Vicia sativa & VISA & garden vetch & UPL & Herb & no & & & \\
\hline Vicia tetrasperma & VITE & lentil vetch & NA & Herb & no & & & \\
\hline Vulpia bromoides & VUBR & brome fescue & NI & Grass & no & & & \\
\hline Vulpia octoflora & VUOC & sixweeks fescue & UPL & Grass & yes & & & \\
\hline
\end{tabular}


Appendix C

\section{Site Maps}





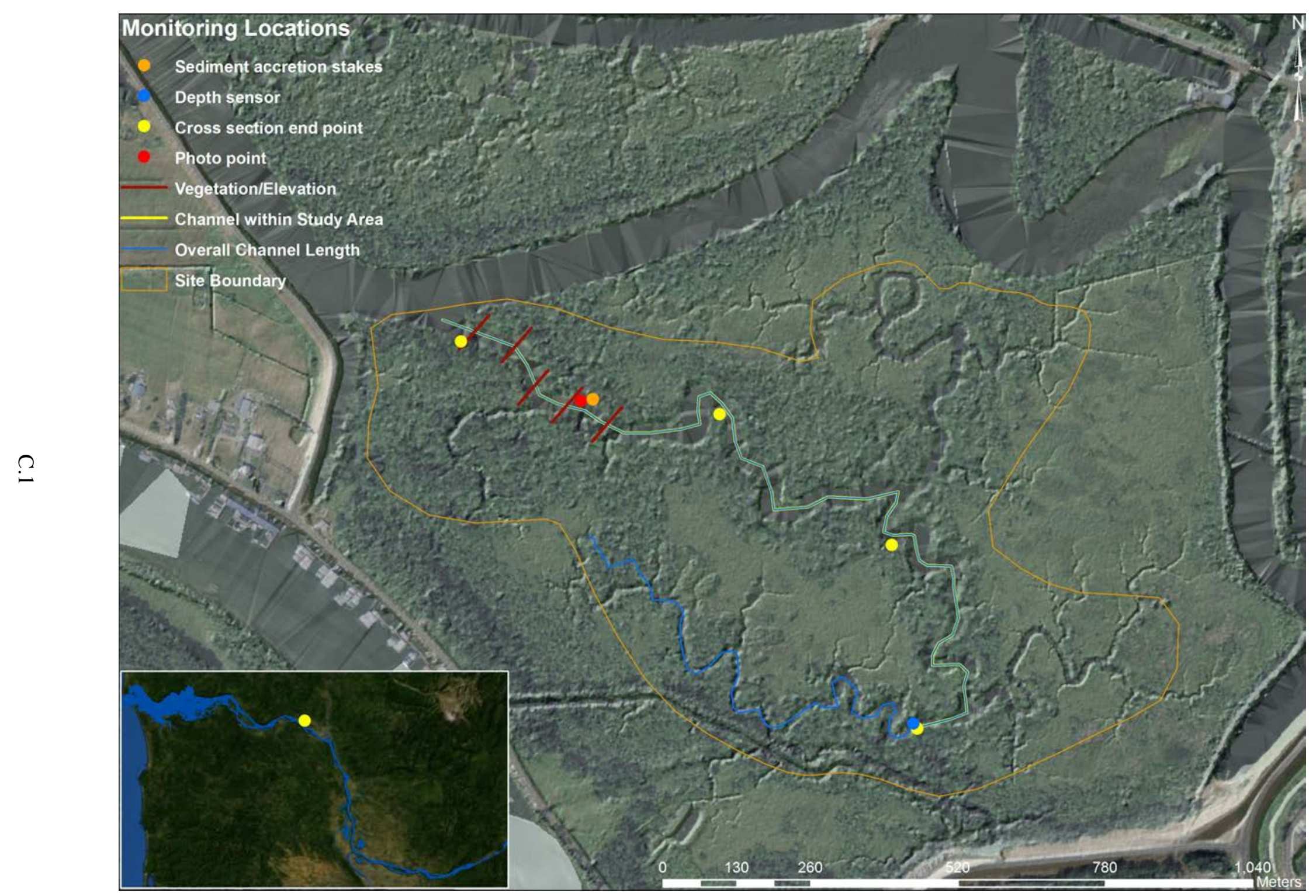

Figure A.1. Map showing the Coal Creek Riparian Wetland site. 


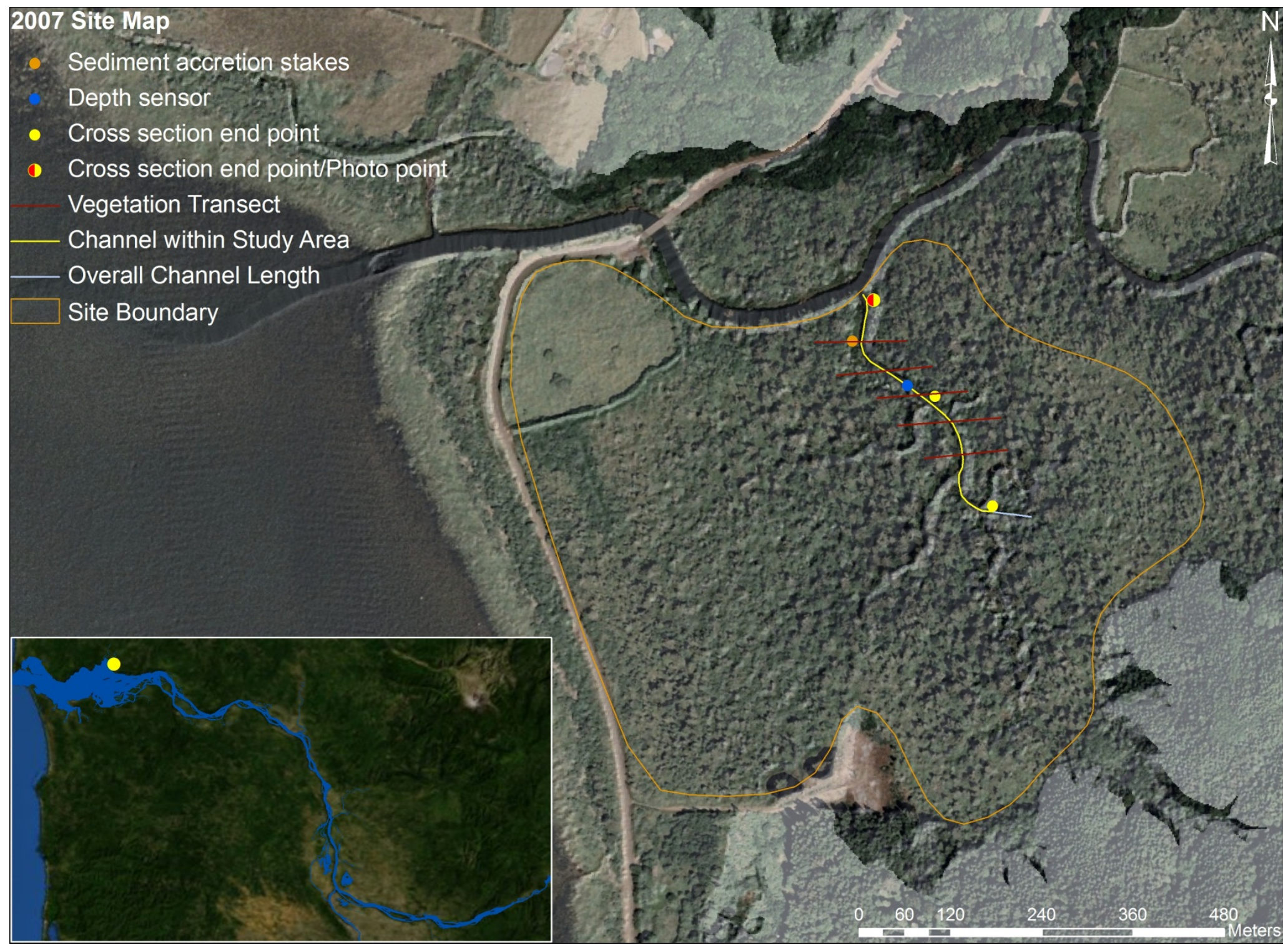

Figure A.2. Map showing the Crooked Creek Swamp site. 


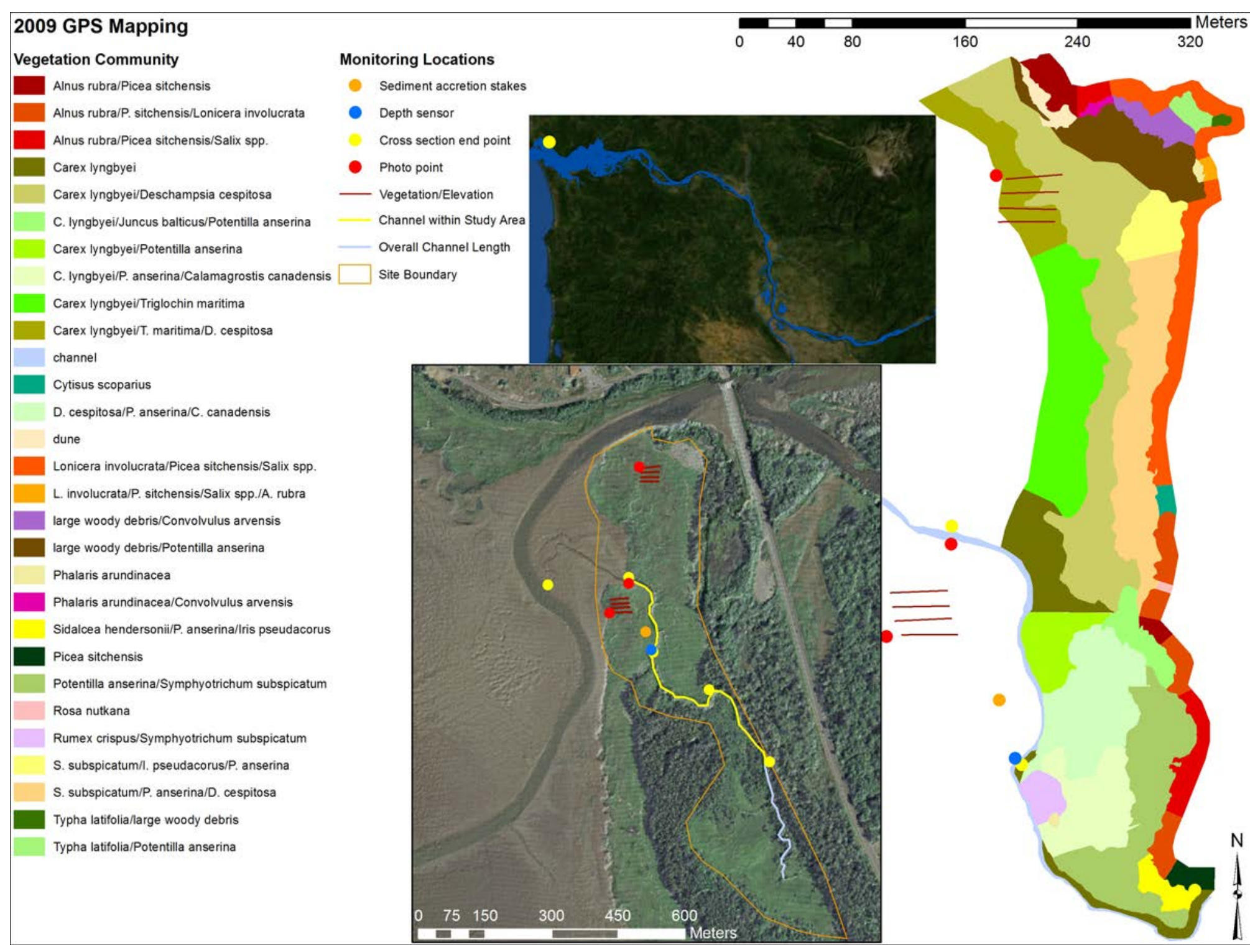

Figure A.3. Map showing the Chinook River Marsh site. 


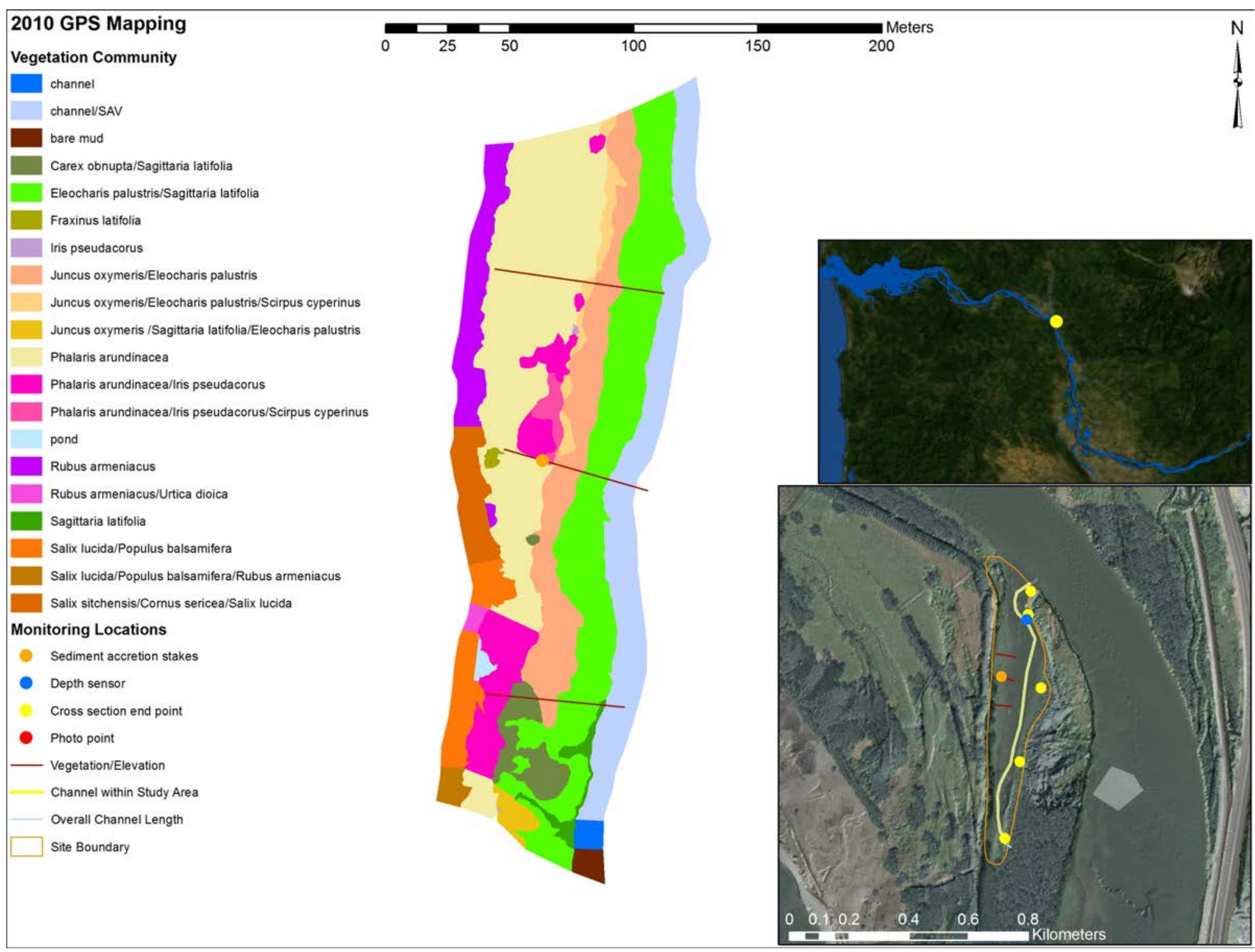

Figure A.4. Map showing the Cottonwood Island 1 Marsh site. 


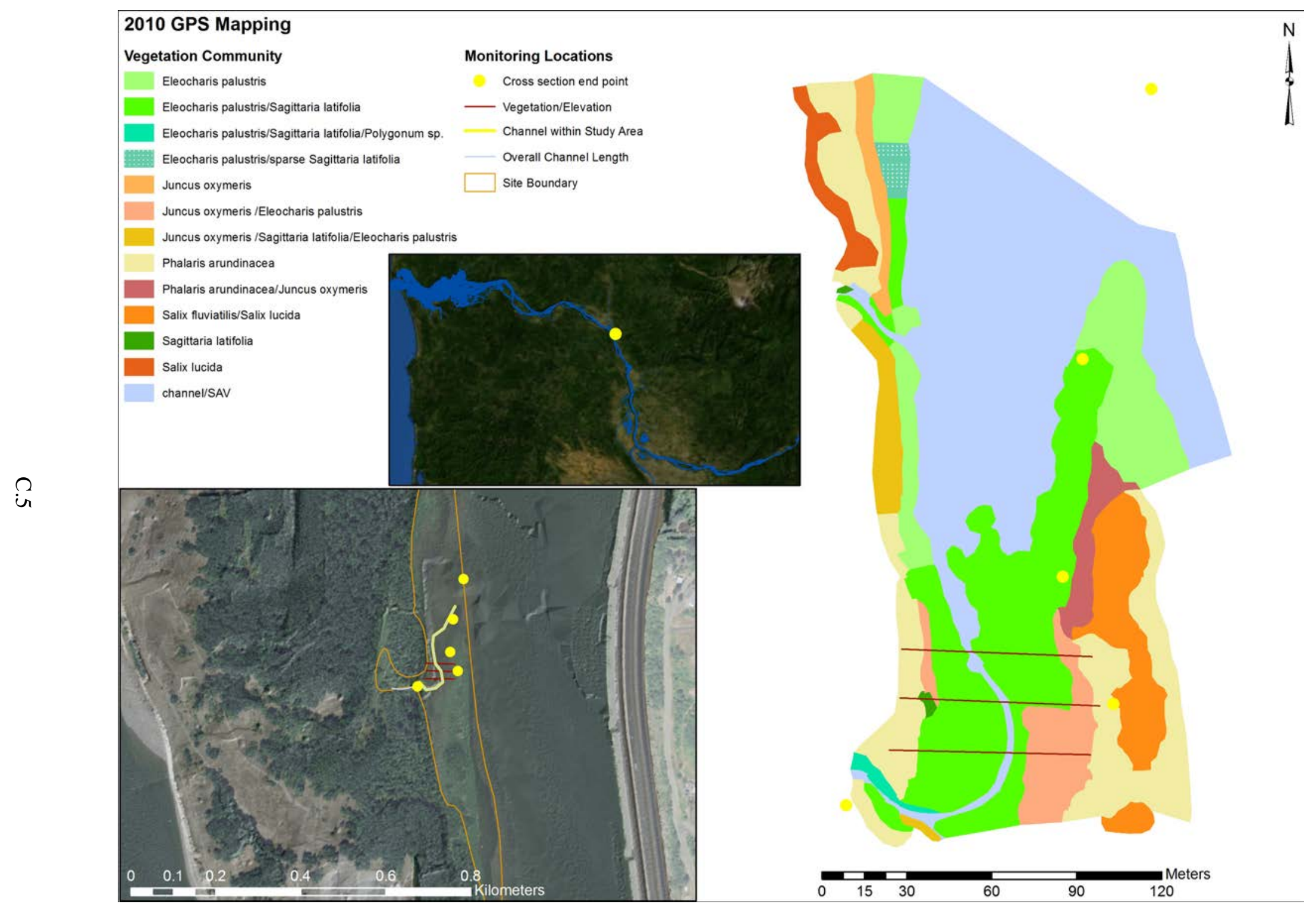

Figure A.5. Map showing the Cottonwood Island 2 Marsh site. 


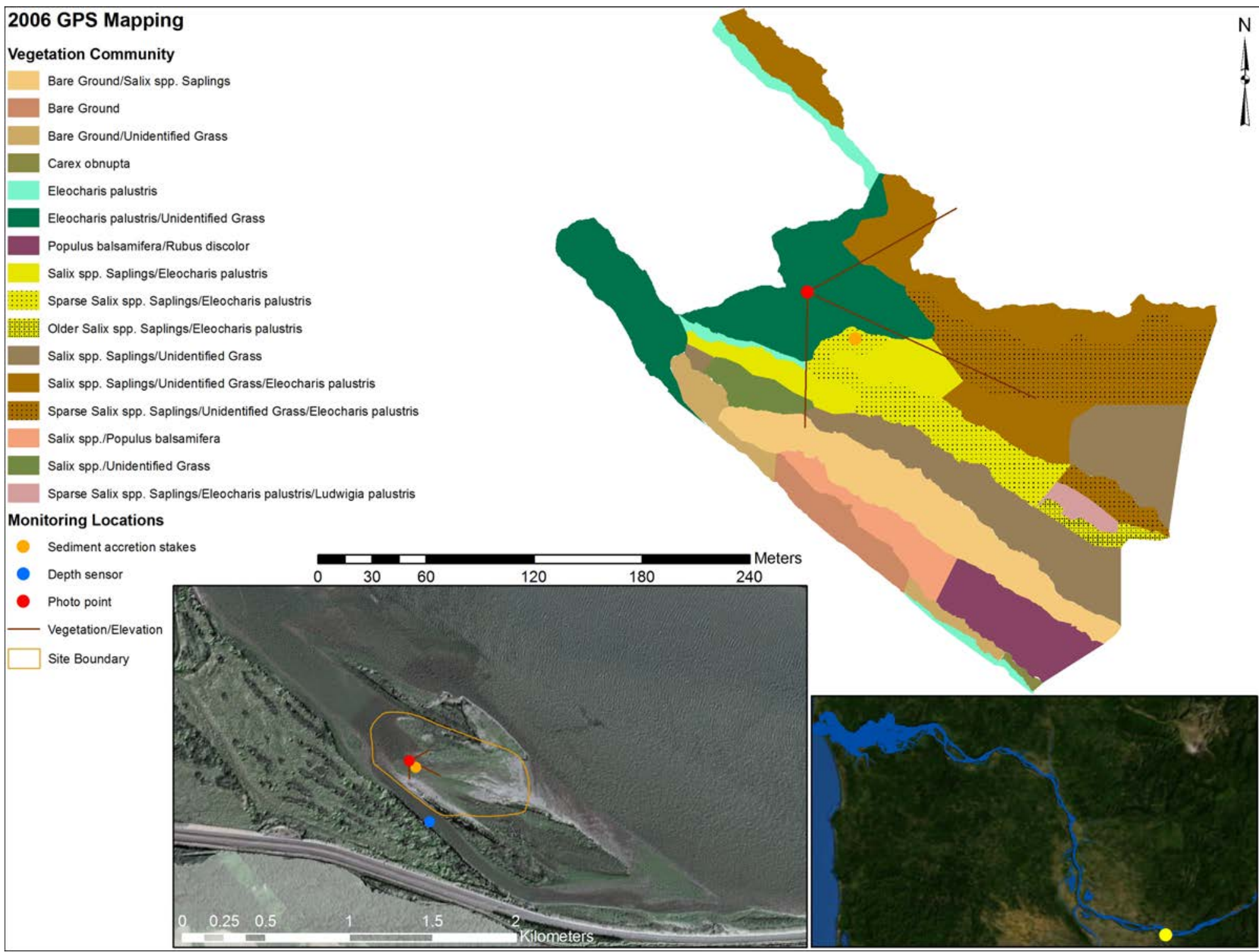

Figure A.6. Map showing the Chatham Island Marsh site. 


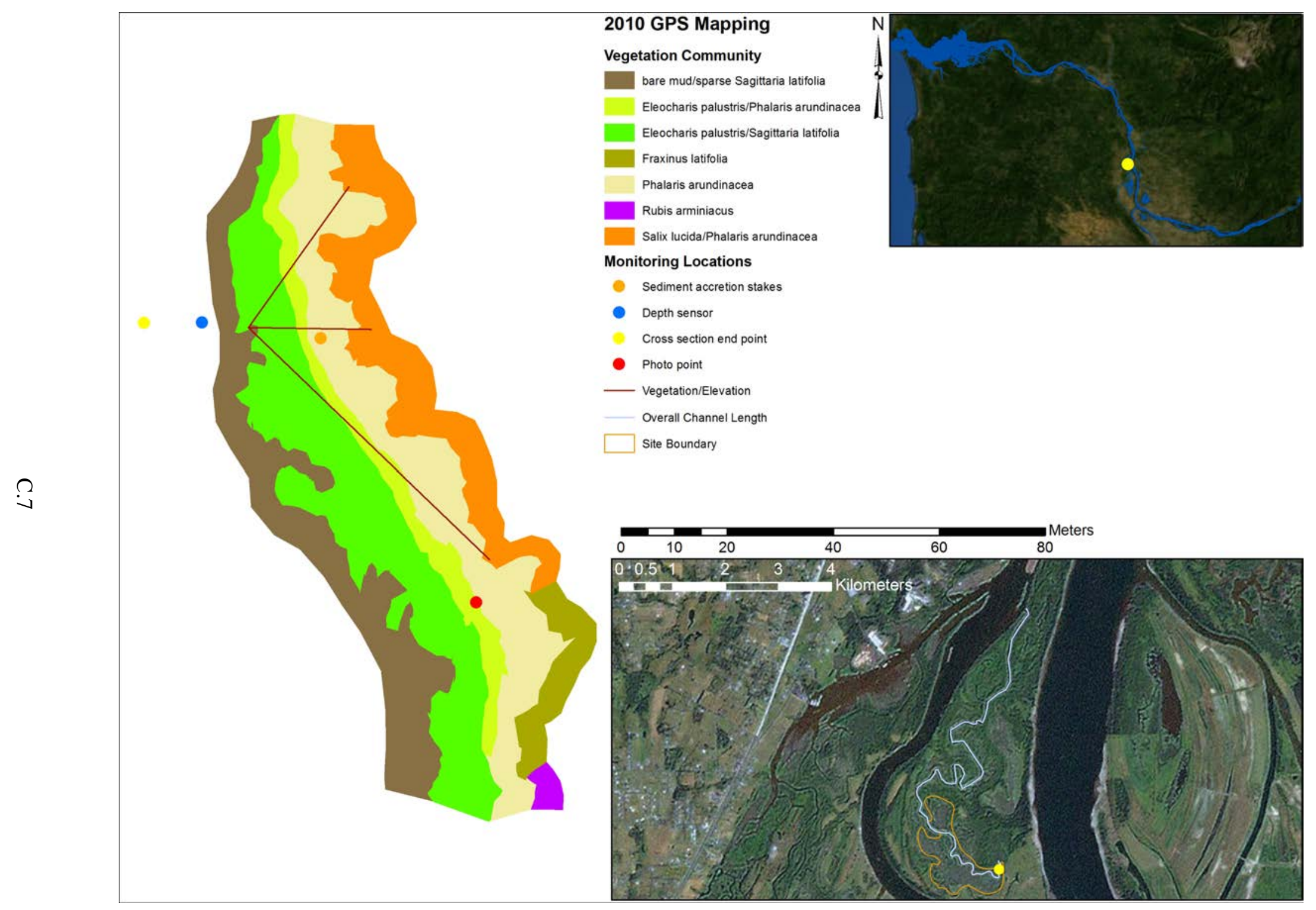

Figure A.7. Map showing the Cunningham Lake Marsh site. 


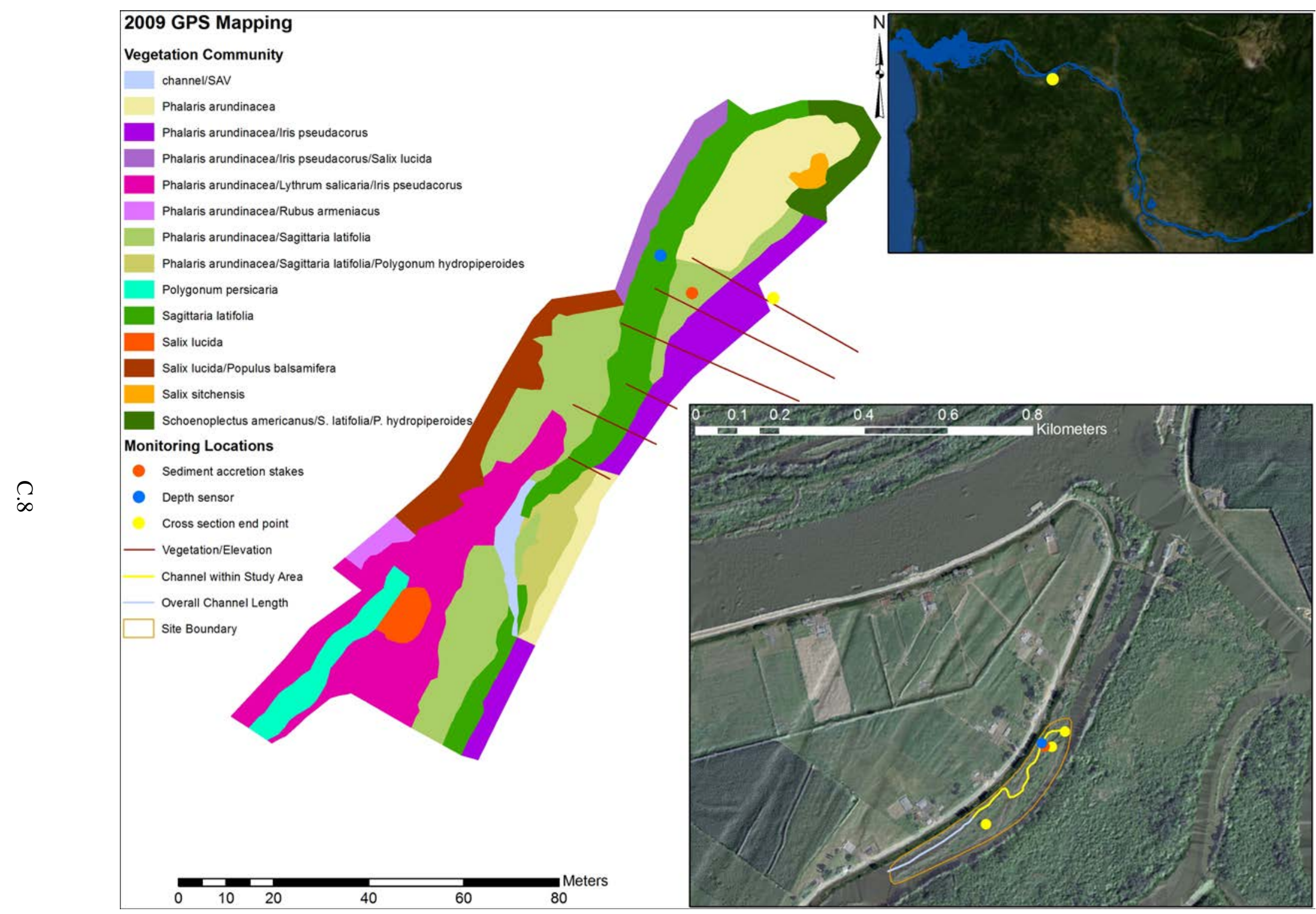

Figure A.8. Map showing the Clatskanie River Marsh site. 


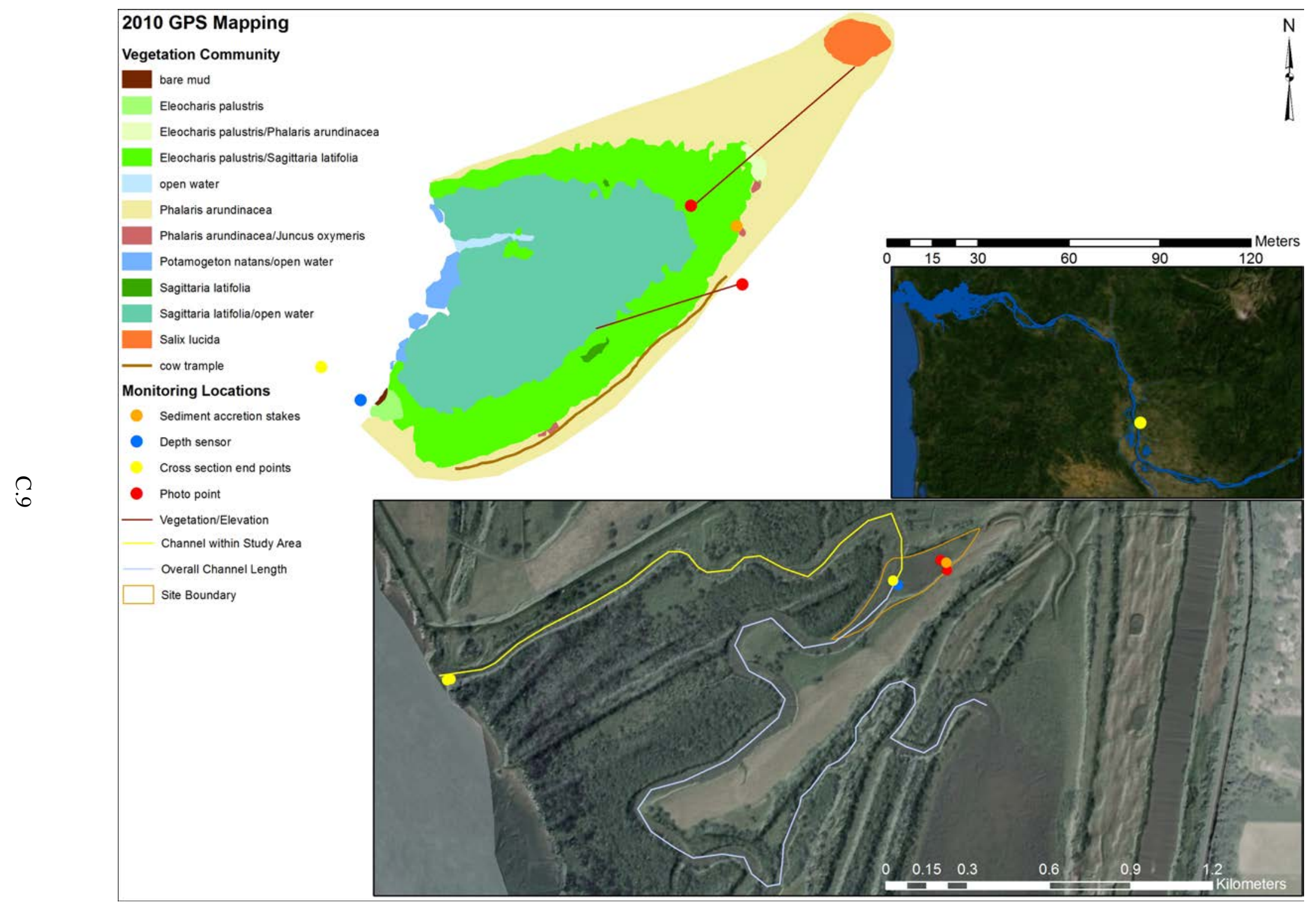

Figure A.9. Map showing the Campbell Slough Marsh site. 


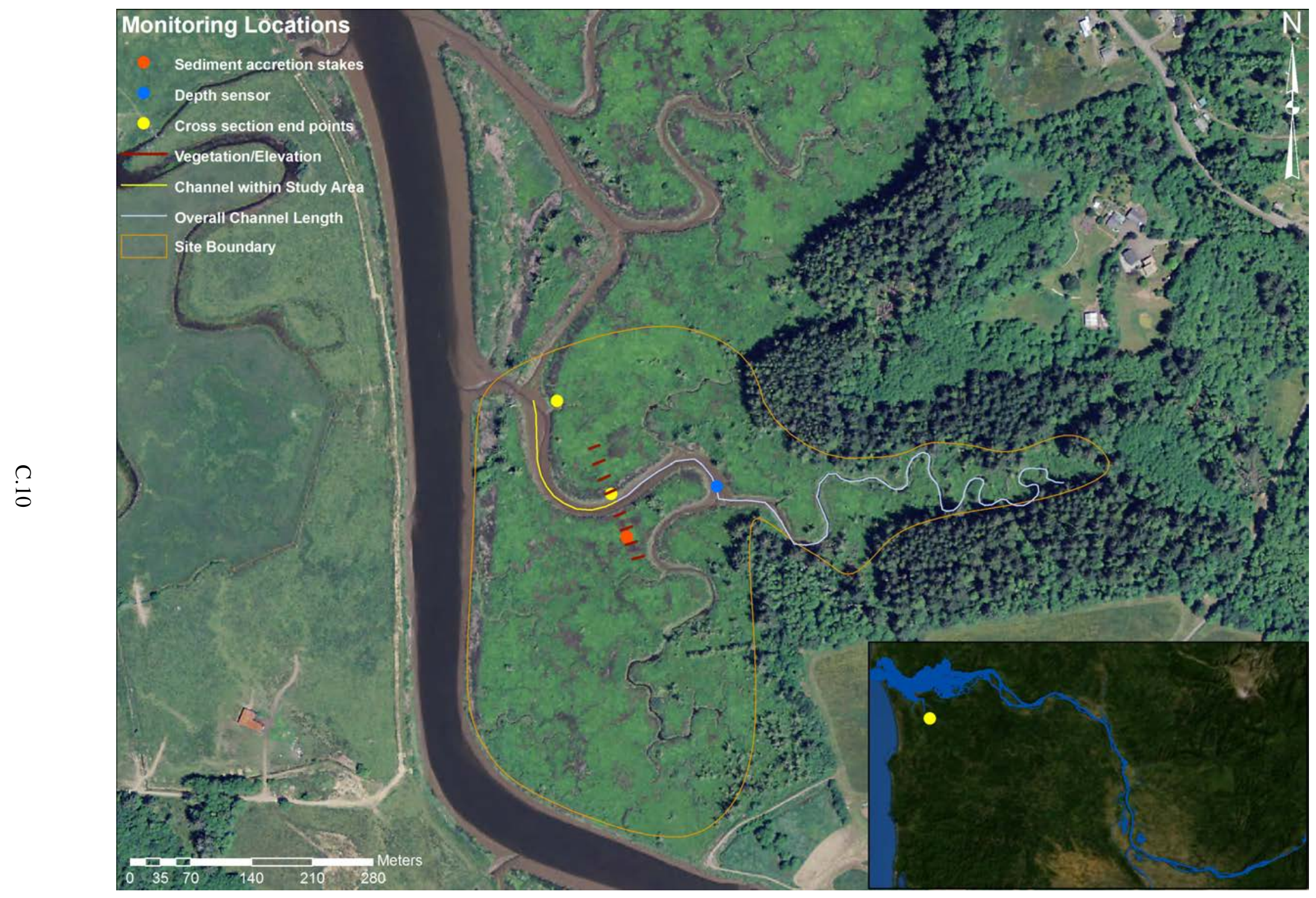

Figure A.10. Map showing the Cooperage Slough Marsh site. 


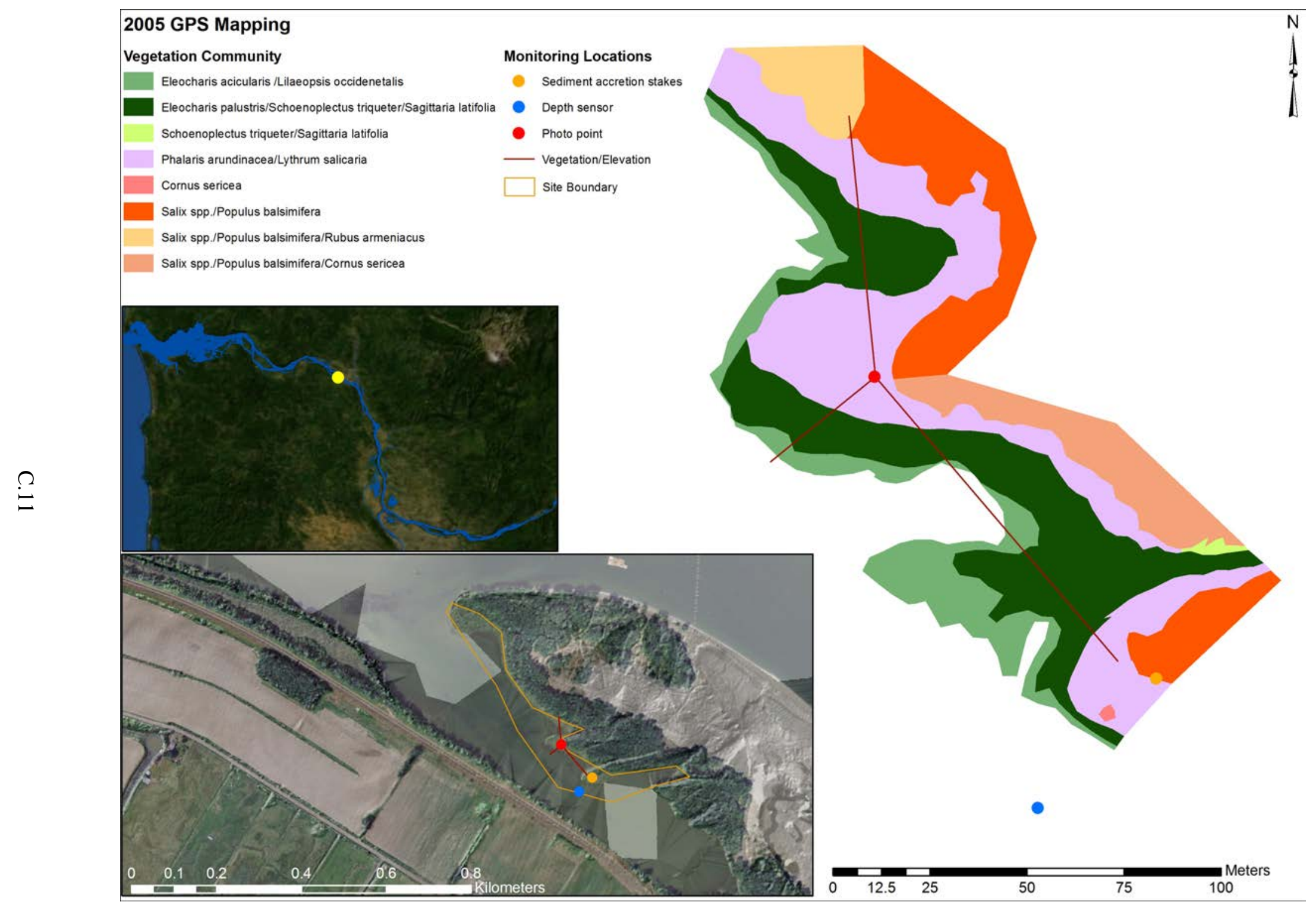

Figure A.11. Map showing the Dibblee Slough Marsh site. 


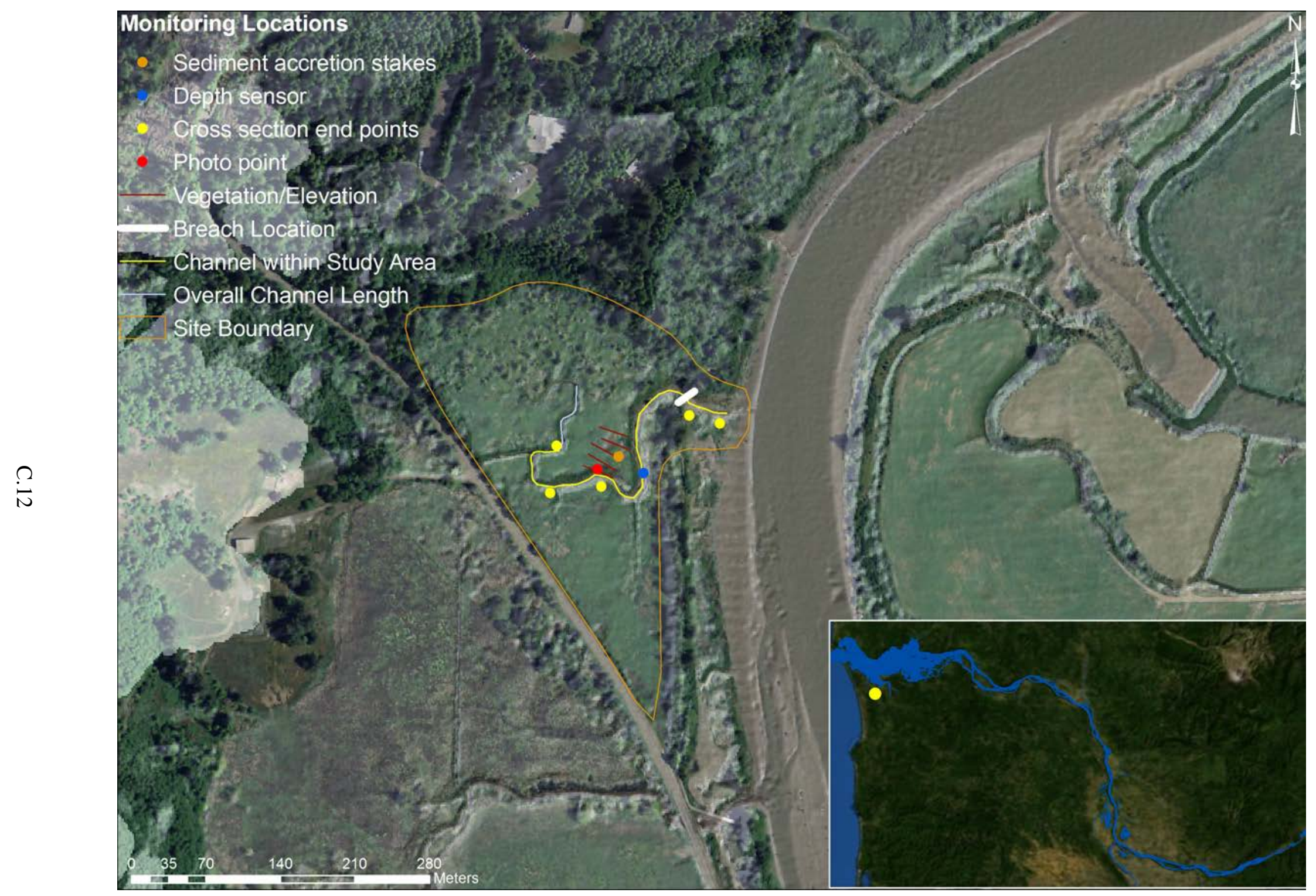

Figure A.12. Map showing the Ft. Clatsop Dike-breach Marsh site. 


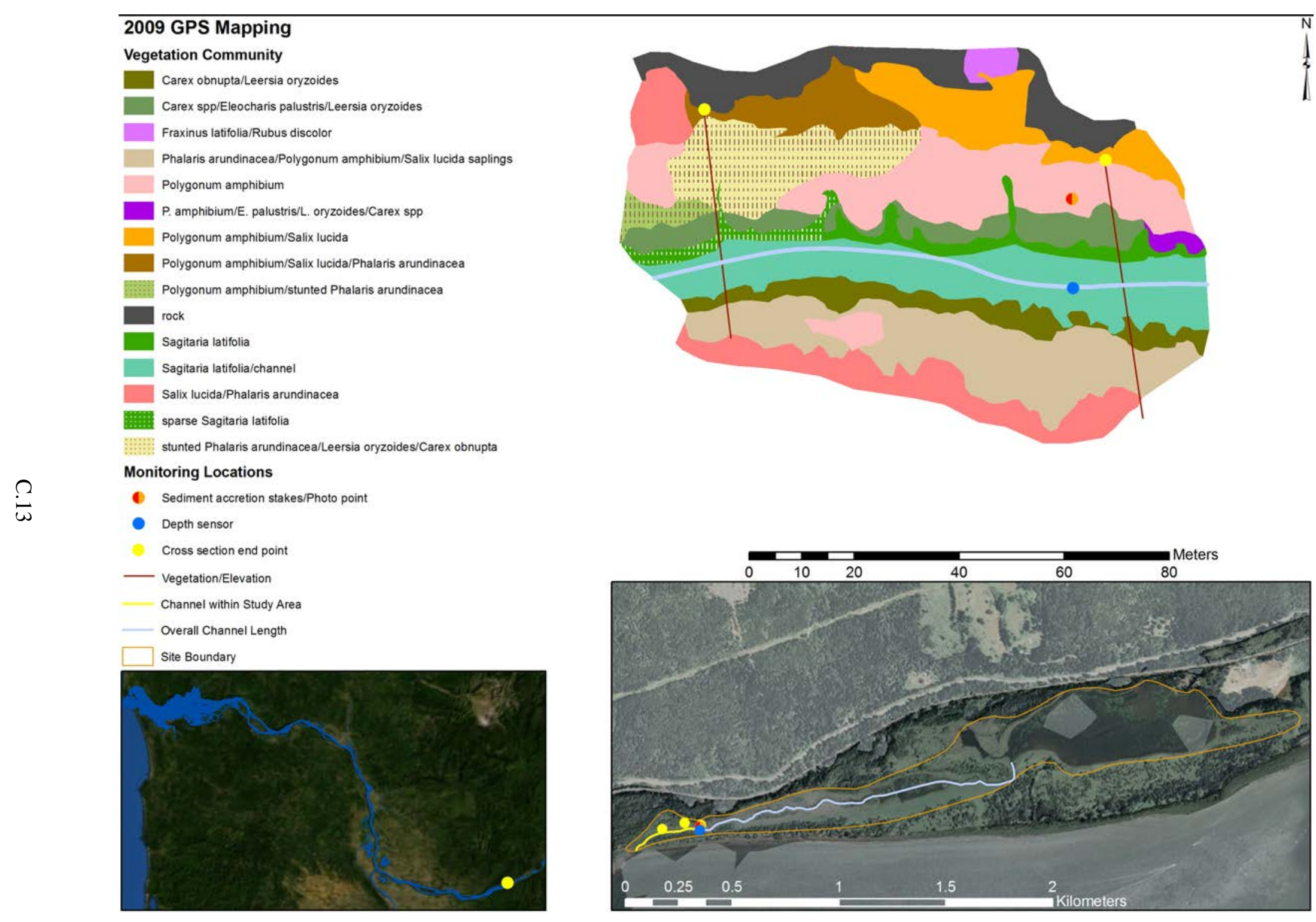

Figure A.13. Map showing the Franz Lake Marsh site. 


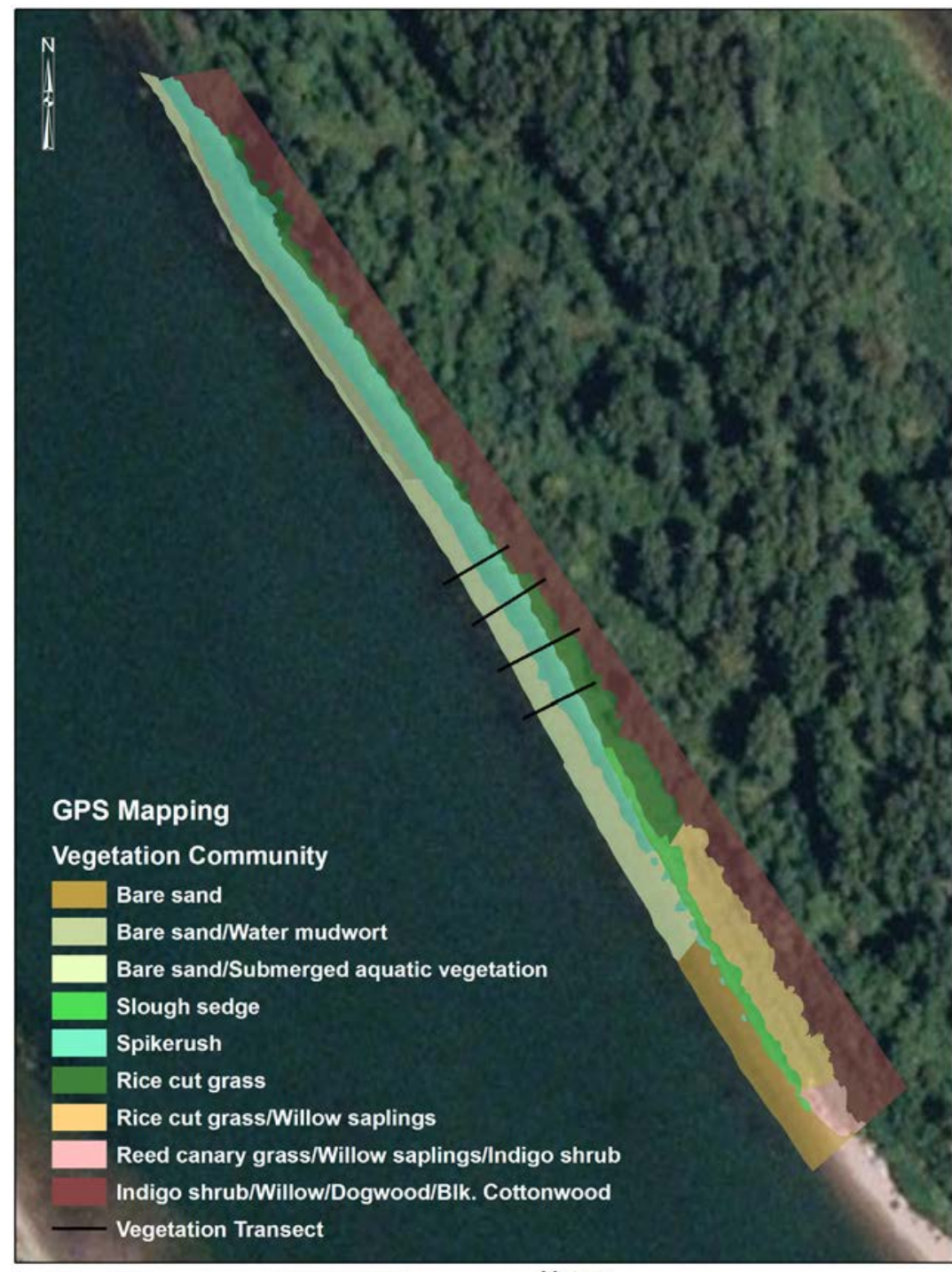

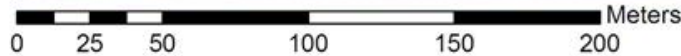

Figure A.14. Map showing the Gary Island Marsh site. 


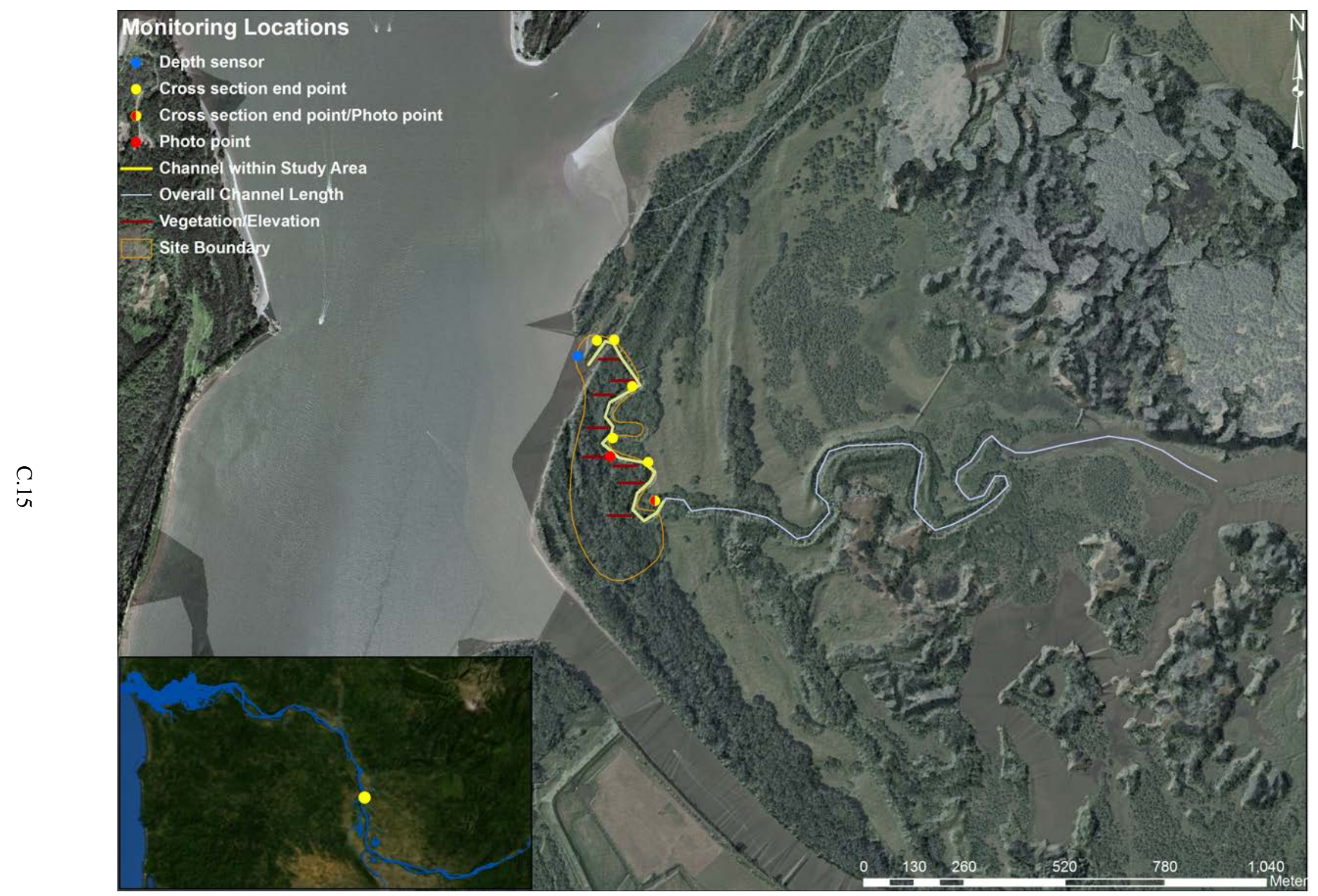

Figure A.15. Map showing the Gee Creek Riparian Wetland site. 


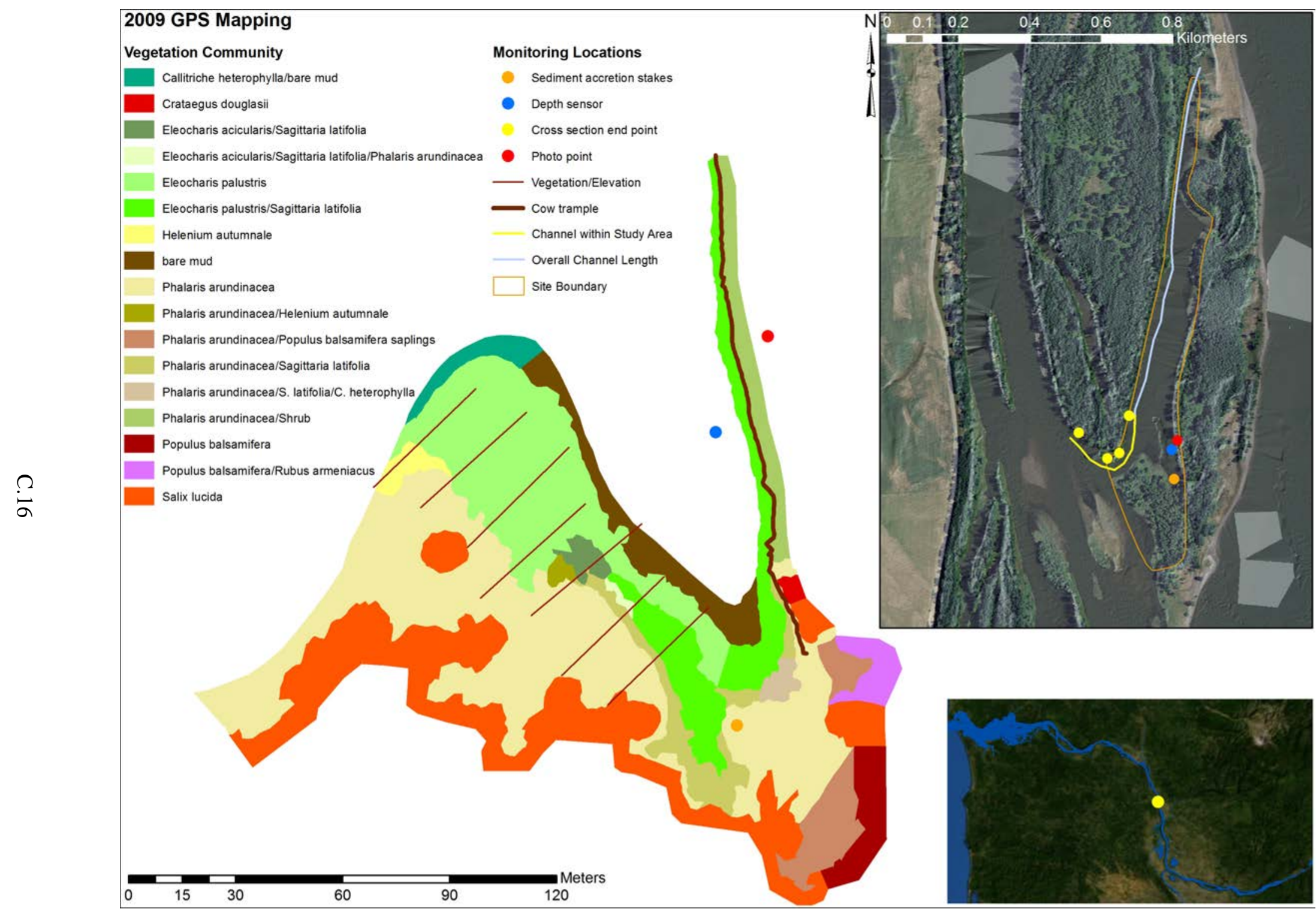

Figure A.16. Map showing the Goat Island Marsh site. 


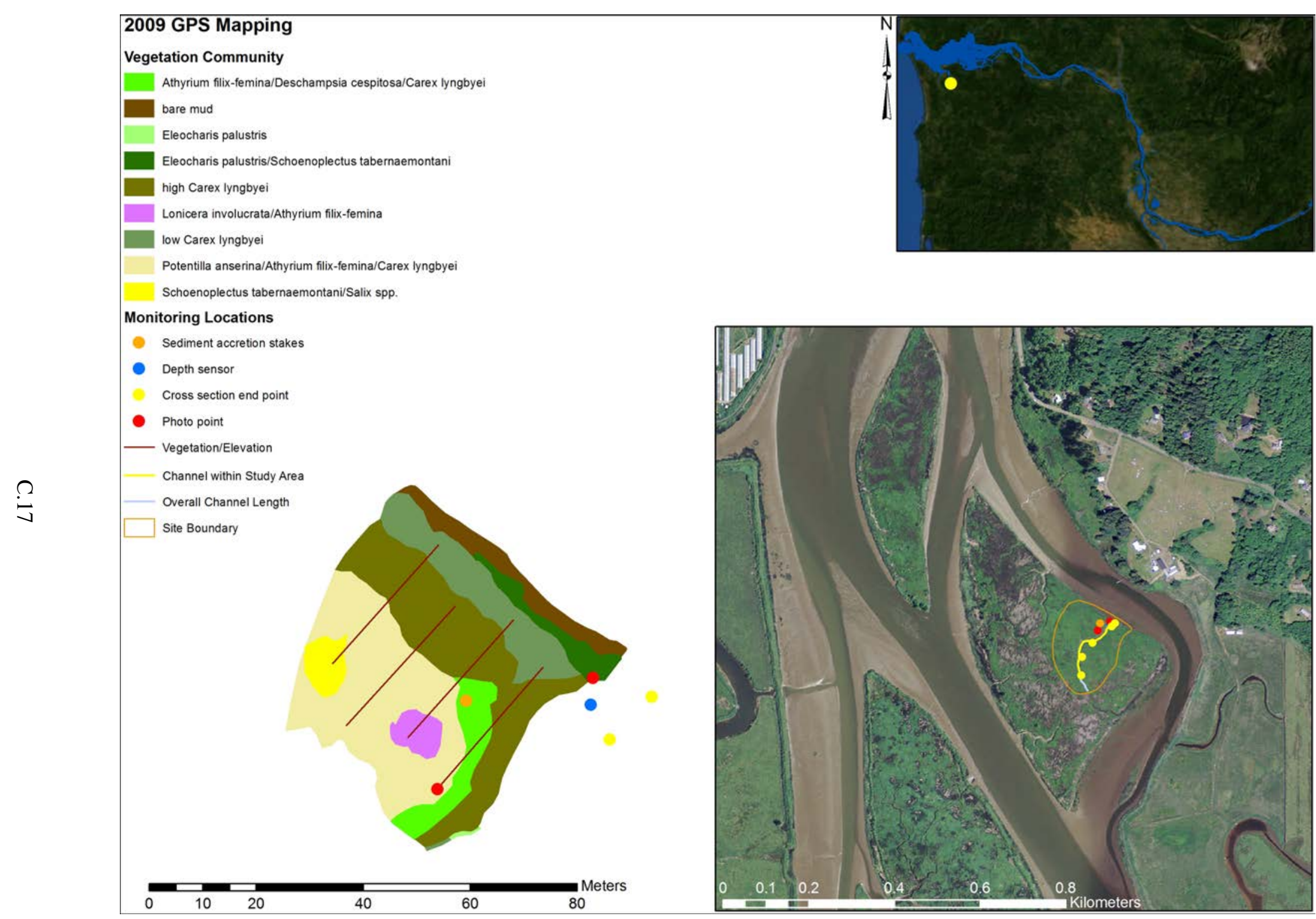

Figure A.17. Map showing the Grant Island Marsh site. 


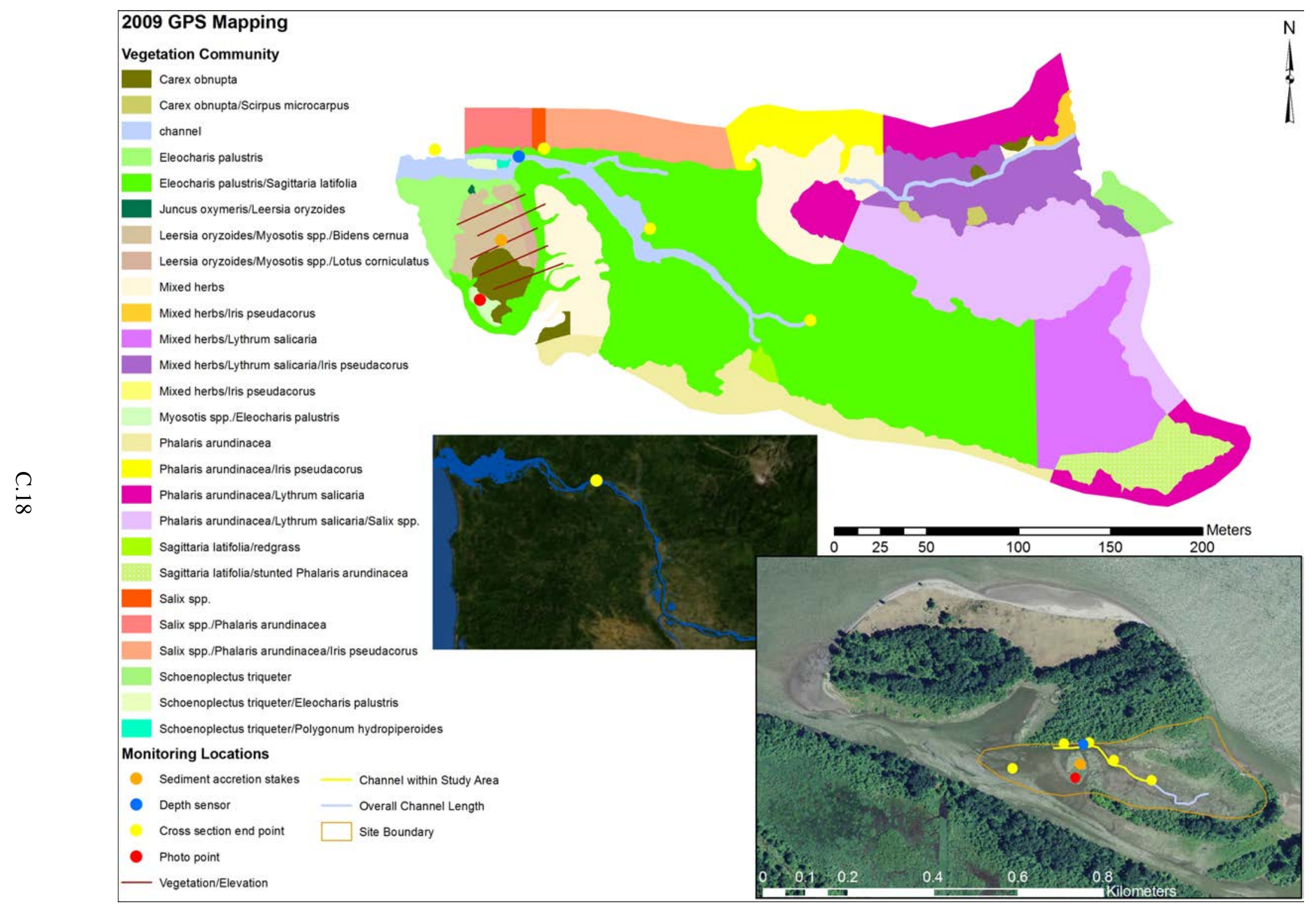

Figure A.18. Map showing the Gull Island Marsh site. 


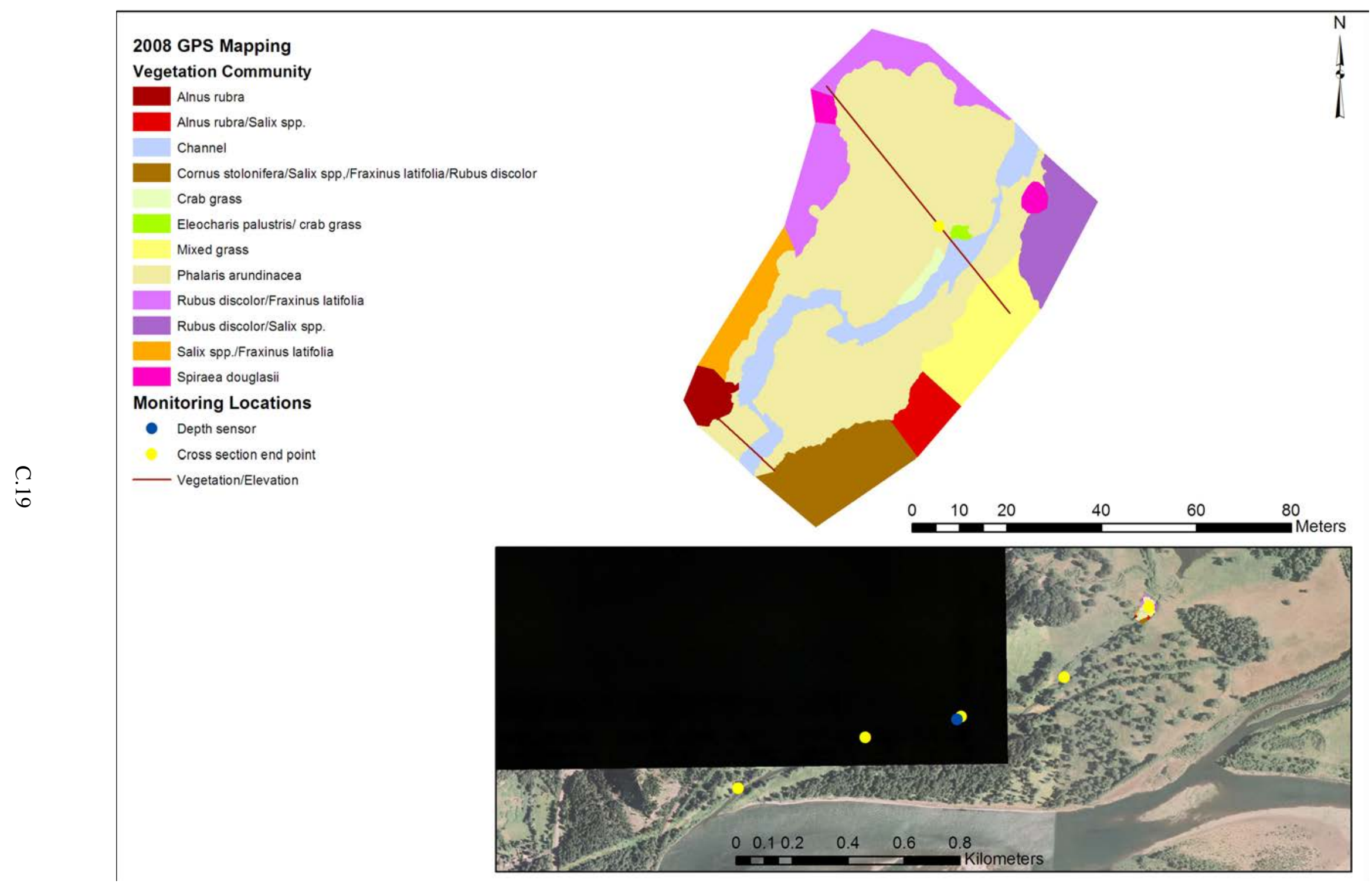

Figure A.19. Map showing the Hardy Creek Marsh site. 


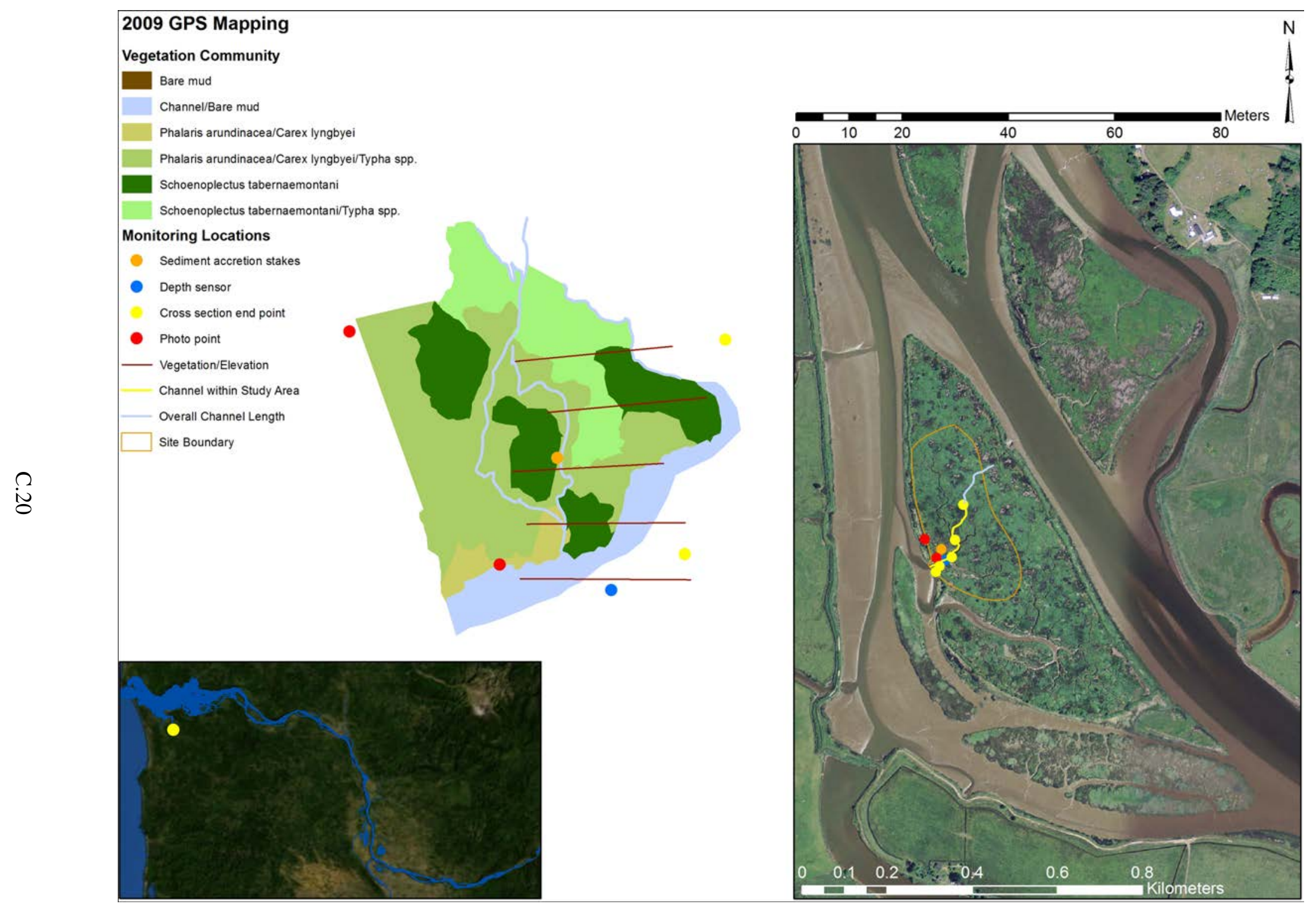

Figure A.20. Map showing the Haven Island Dike-breach Marsh site. 


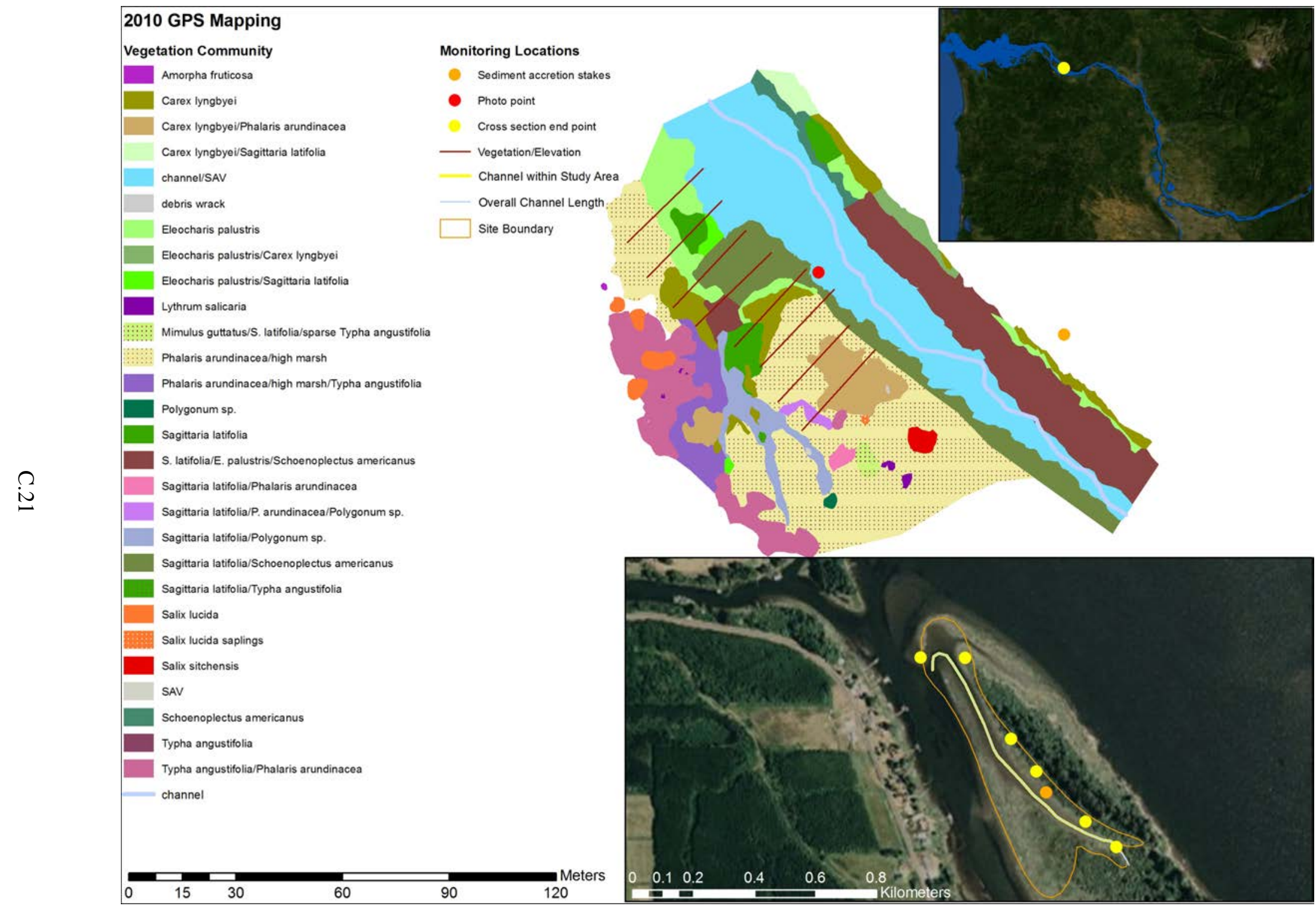

Figure A.21. Map showing the Jackson Island Marsh site. 


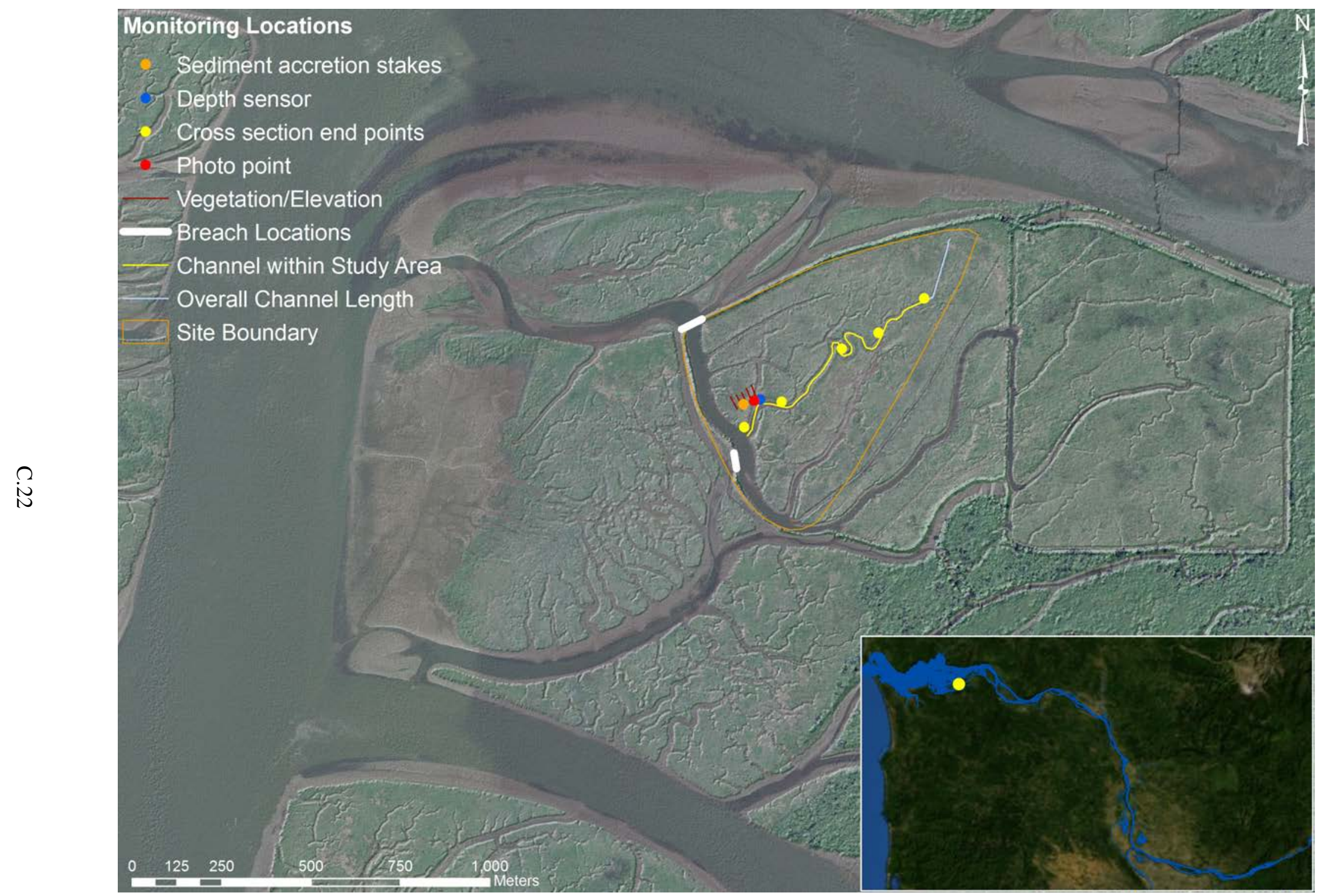

Figure A.22. Map showing the Karlson Island Dike-breach Marsh site. 


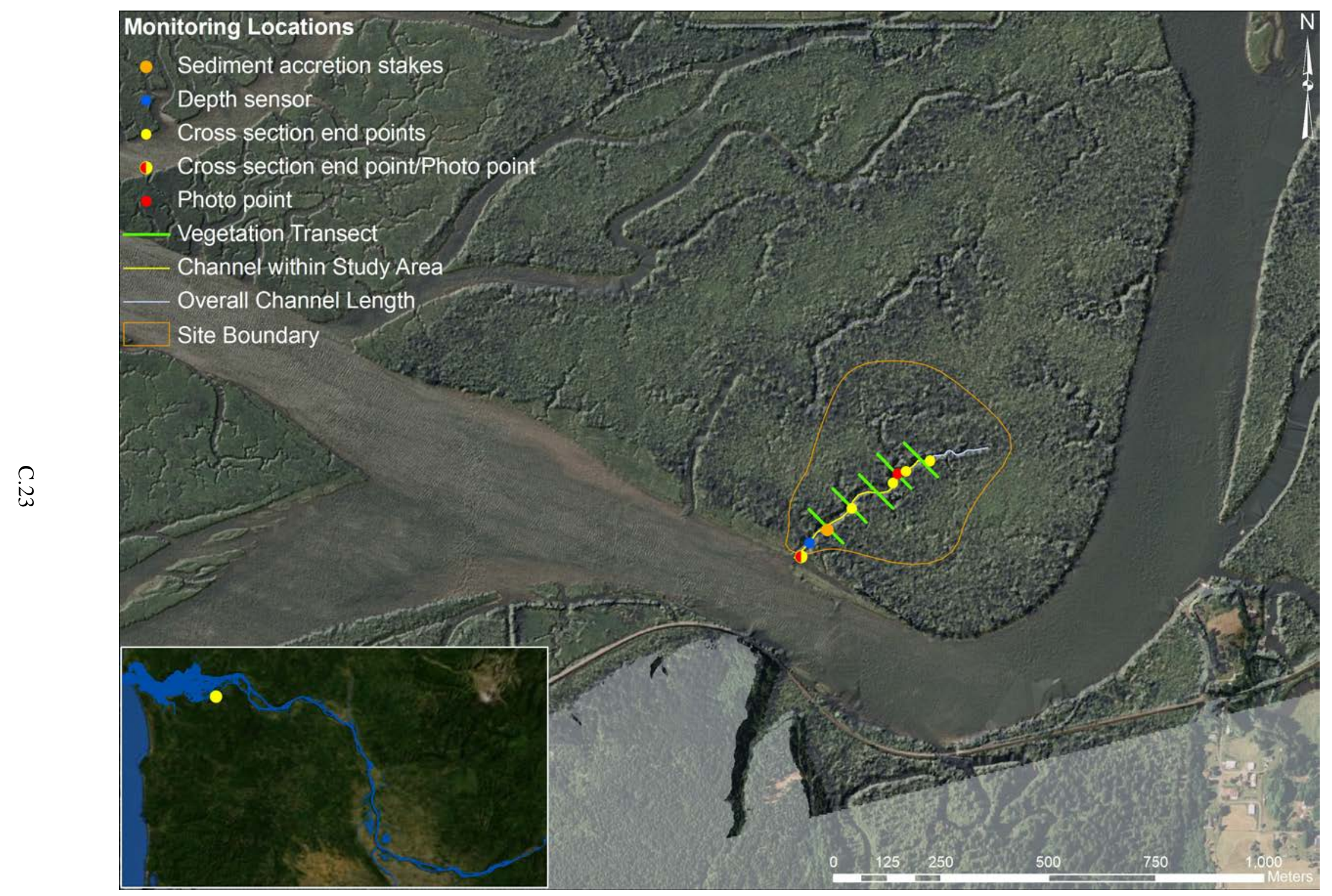

Figure A.23. Map showing the Karlson Island Swamp site. 


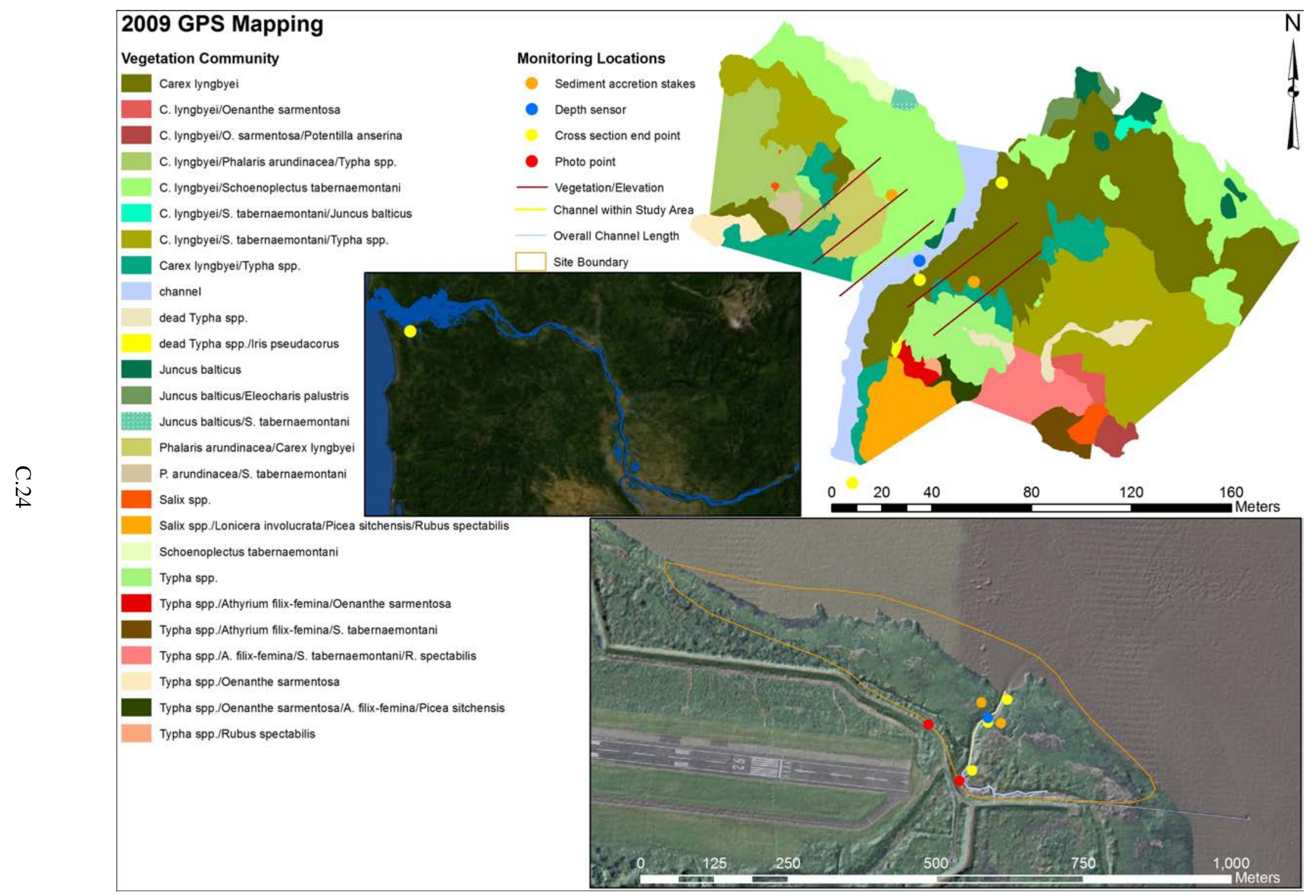

Figure A.24. Map showing the Lewis \& Clark River (mouth) Marsh site. 


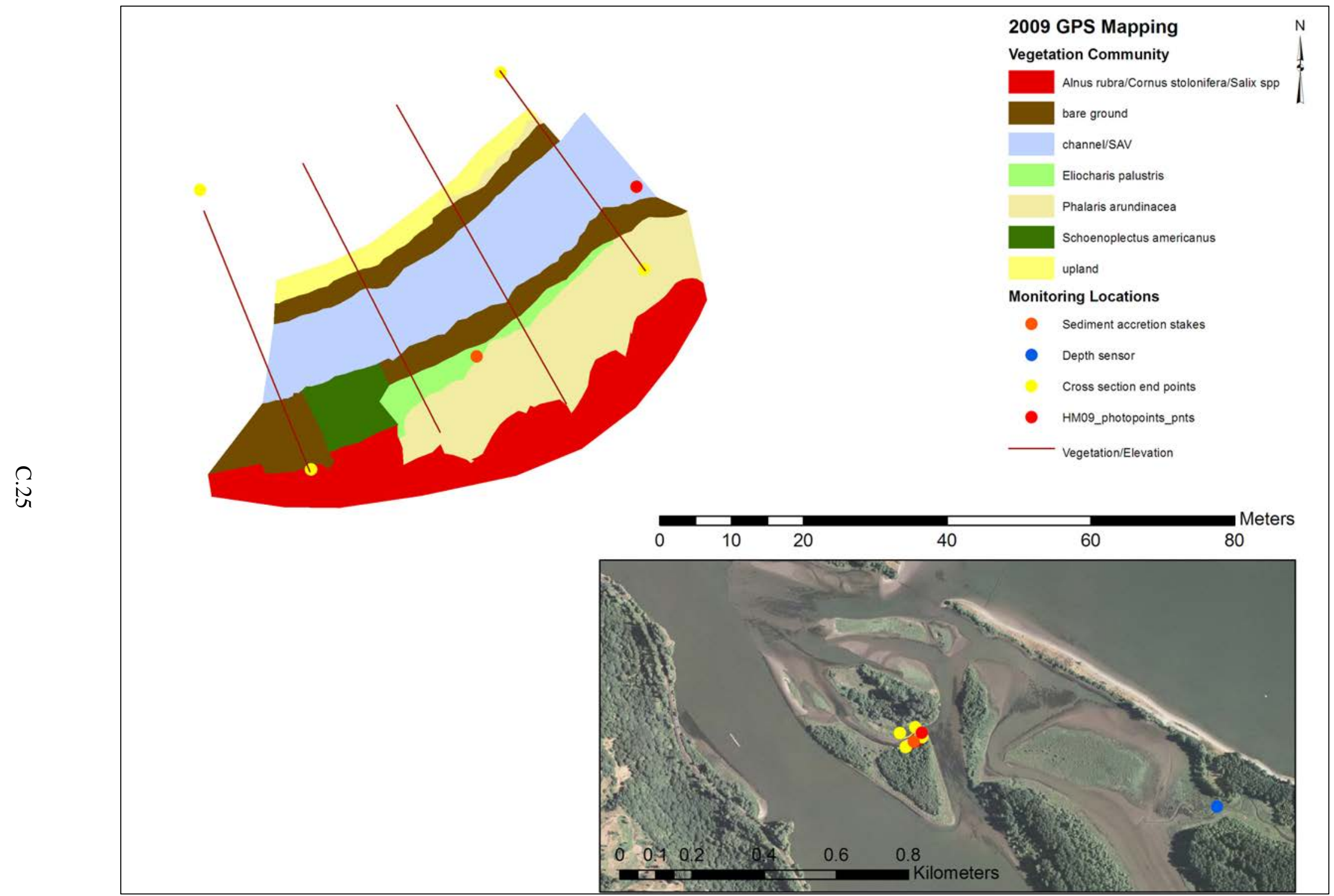

Figure A.25. Map showing the Lord Island 1 Marsh site. 


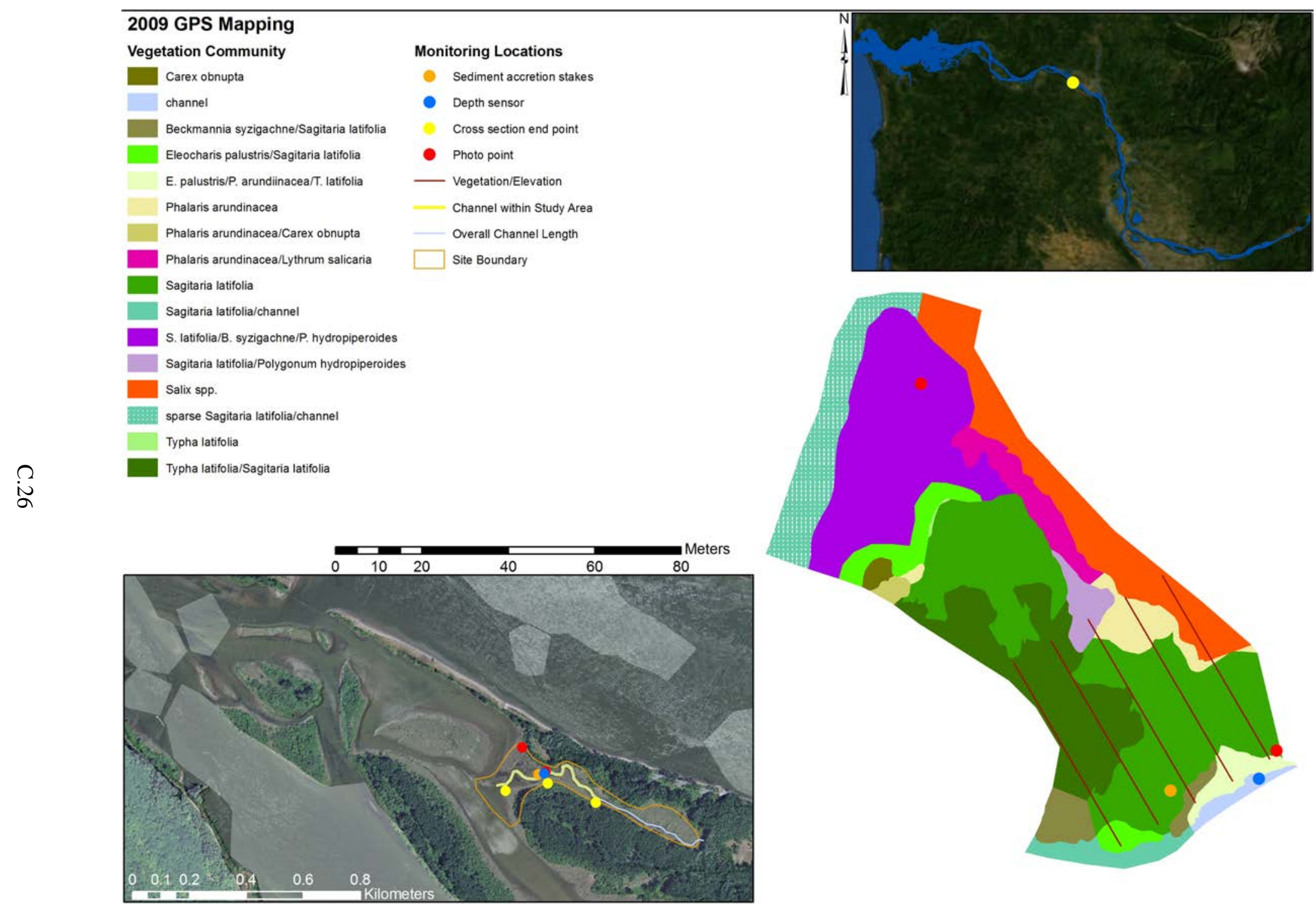

Figure A.26. Map showing the Lord Island 2 Marsh site. 


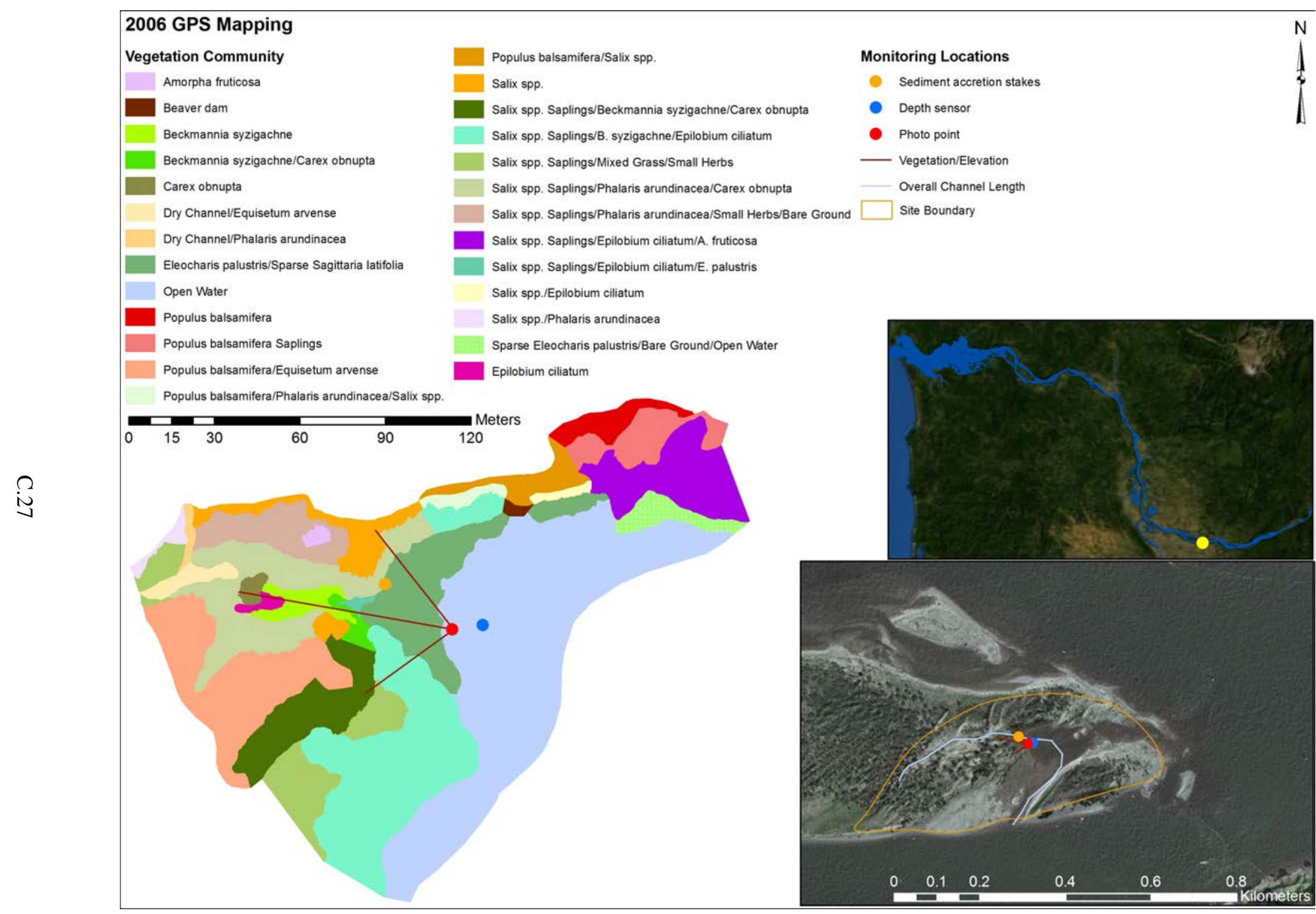

Figure A.27. Map showing the McGuire Island Marsh site. 


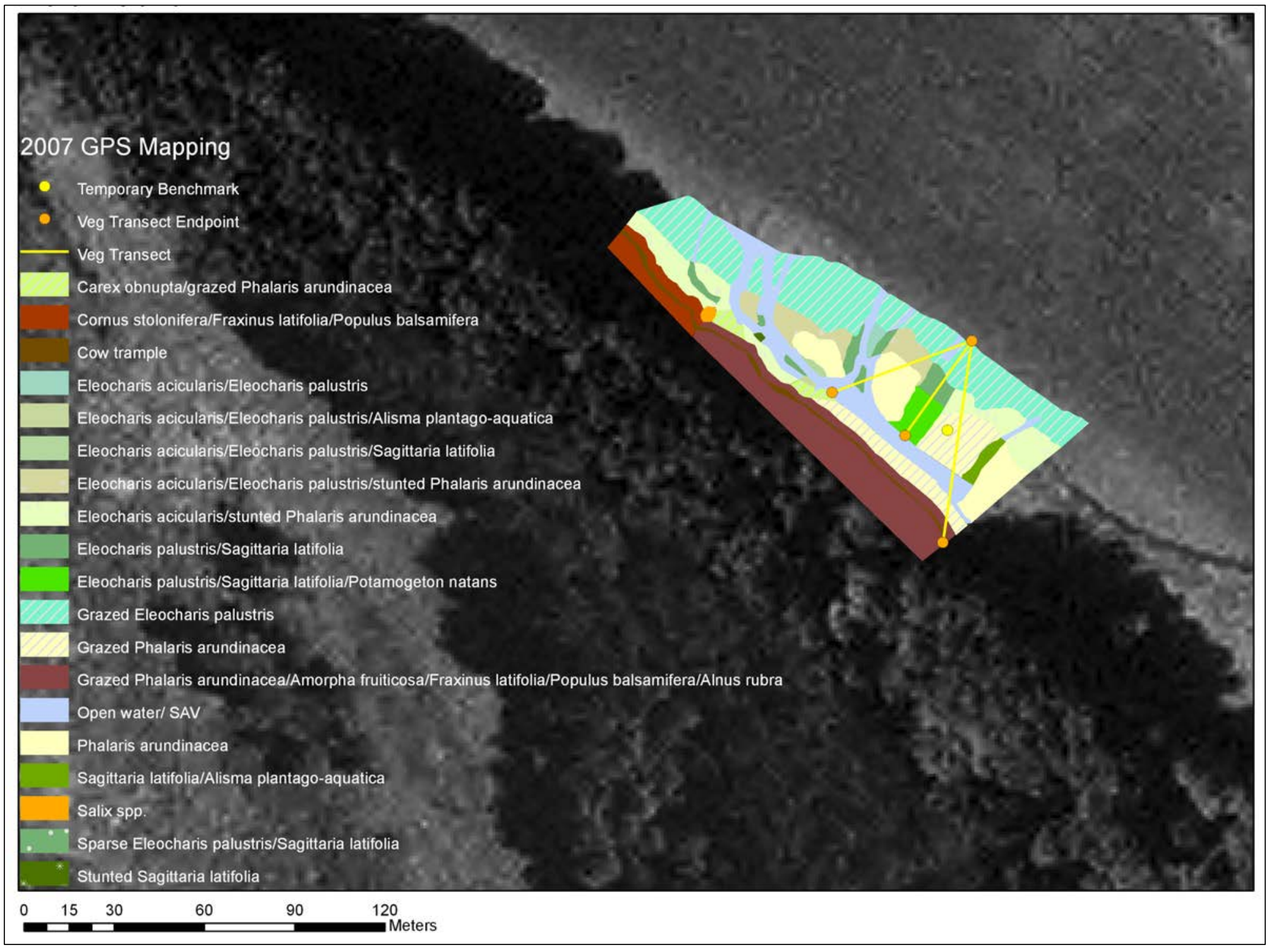

Figure A.28. Map showing the Martin Island Marsh site. 


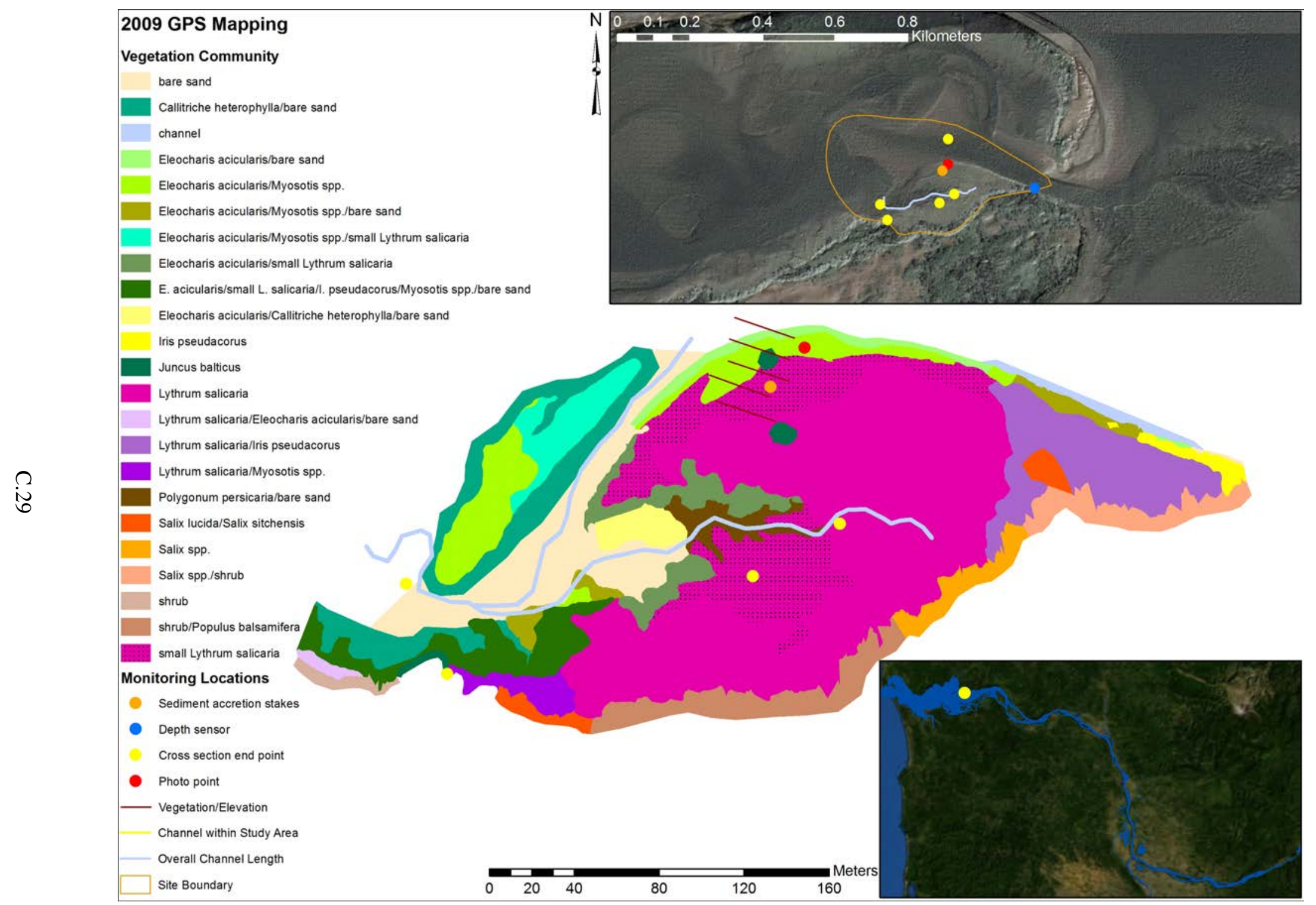

Figure A.29. Map showing the Miller Sands Marsh site. 


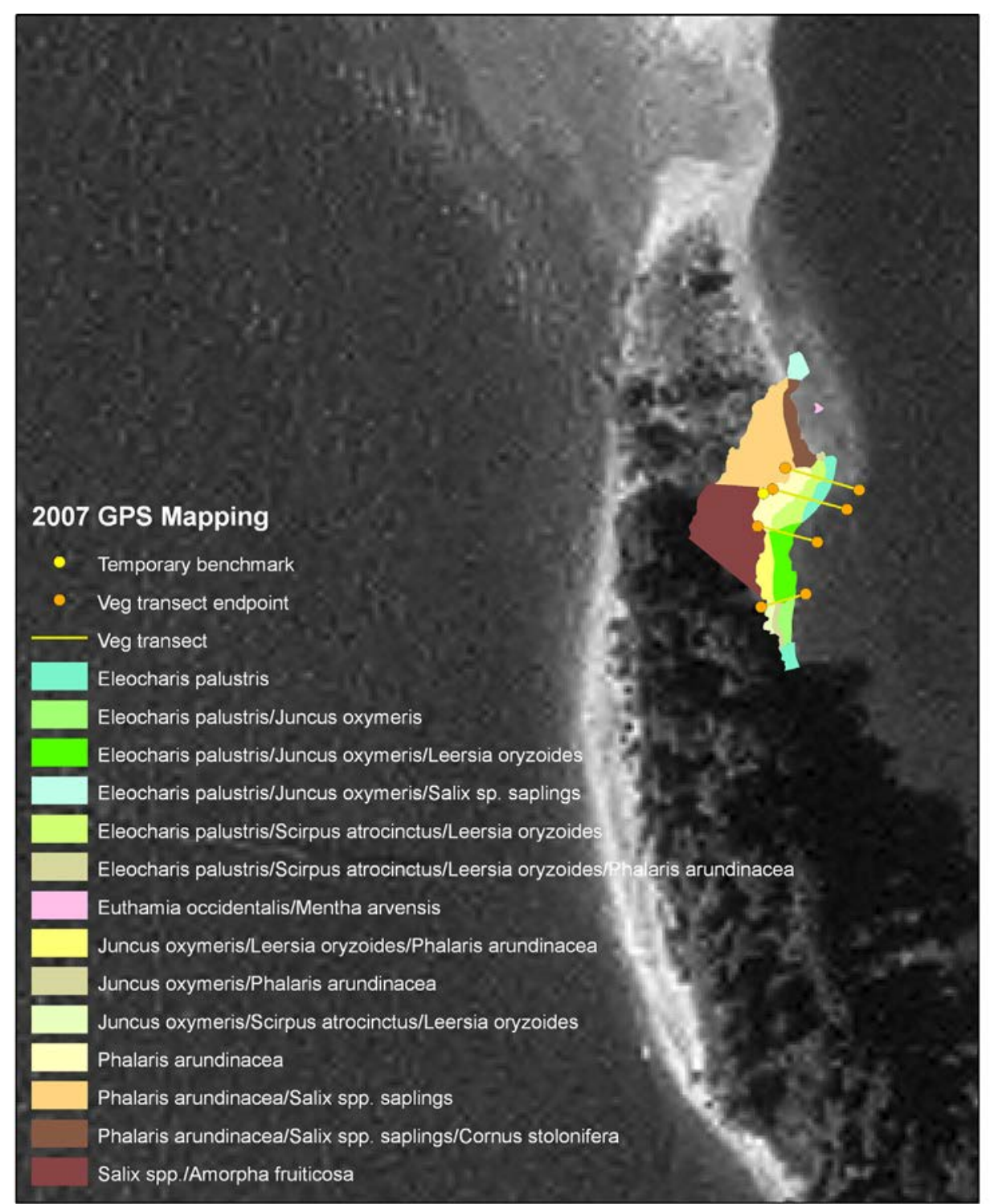

$0 \quad 15 \quad 30$

60 90 120

Figure A.30. Map showing the No-Name Island Marsh site. 


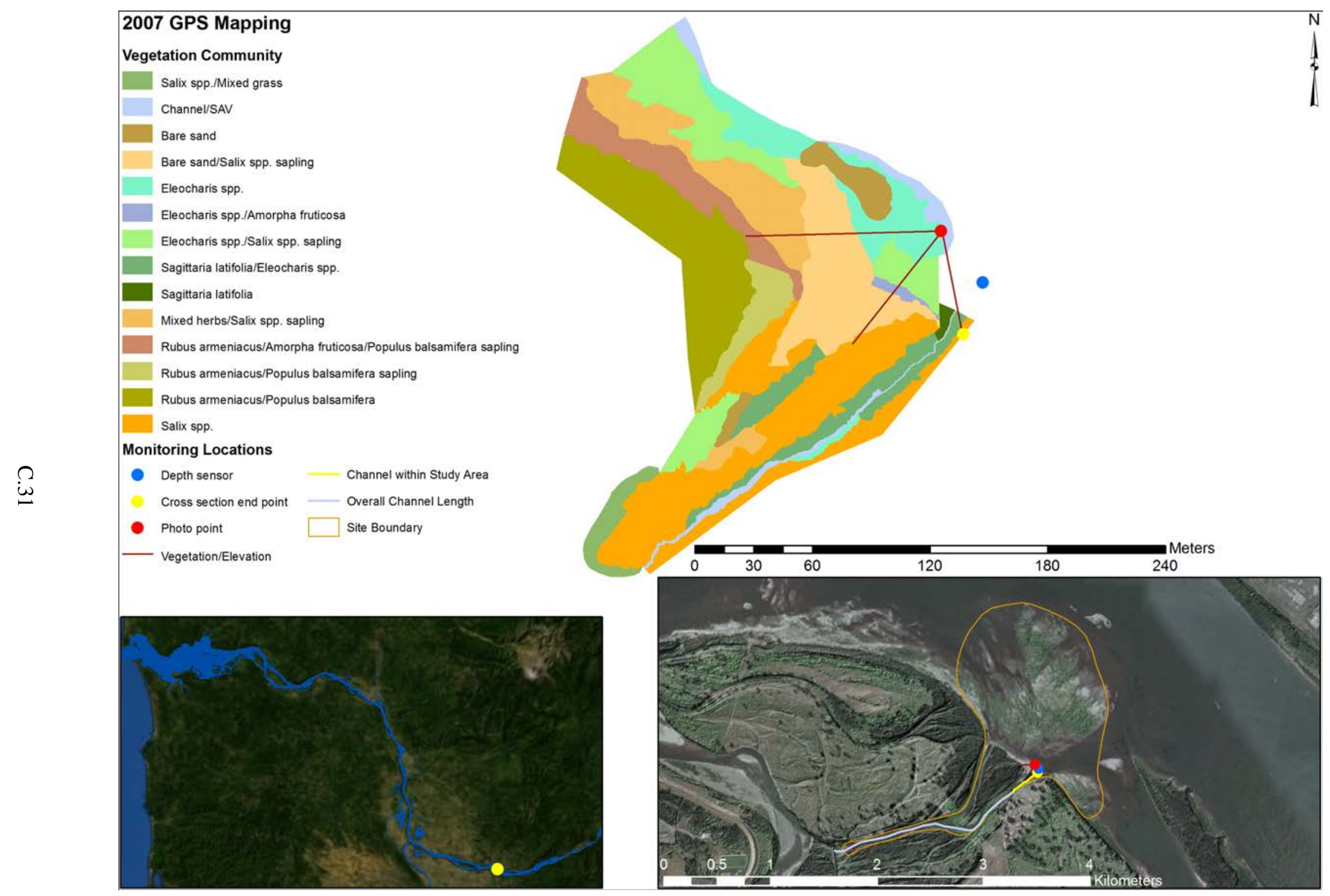

Figure A.31. Map showing the Sandy River Delta (old channel mouth) Marsh site. 


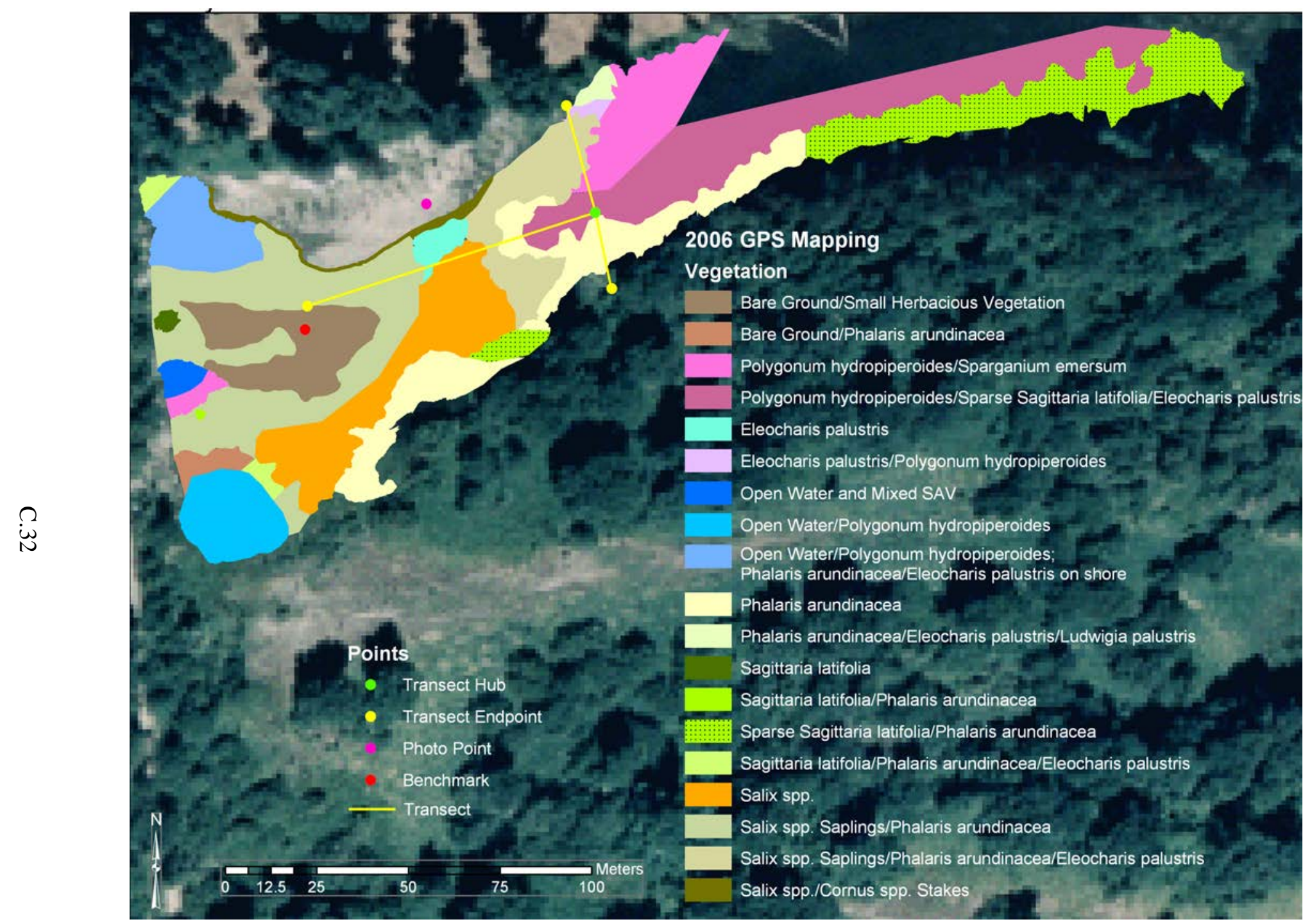

Figure A.32. Map showing the Old Sandy River Channel Marsh site. 


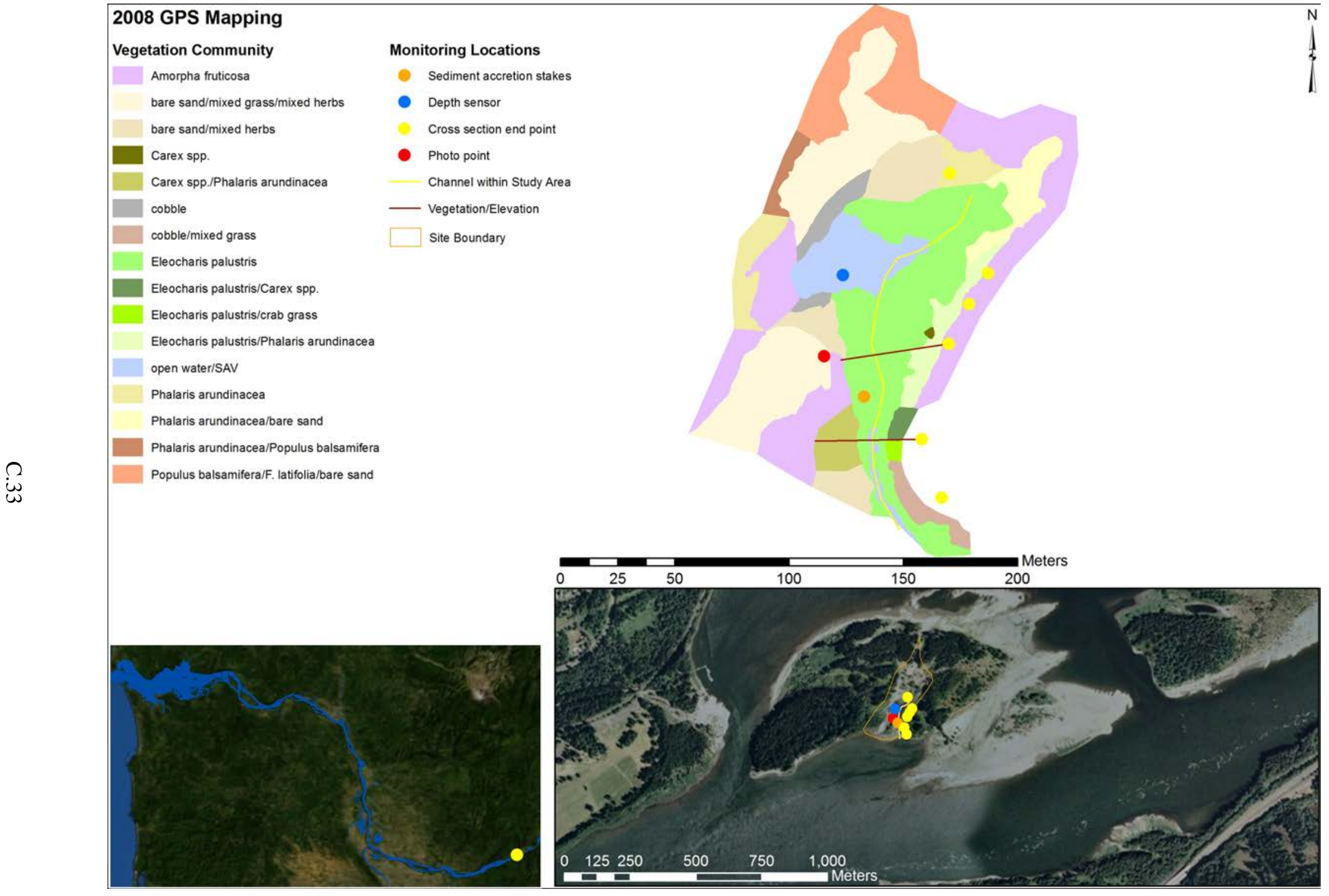

Figure A.33. Map showing the Pierce Island Marsh site. 


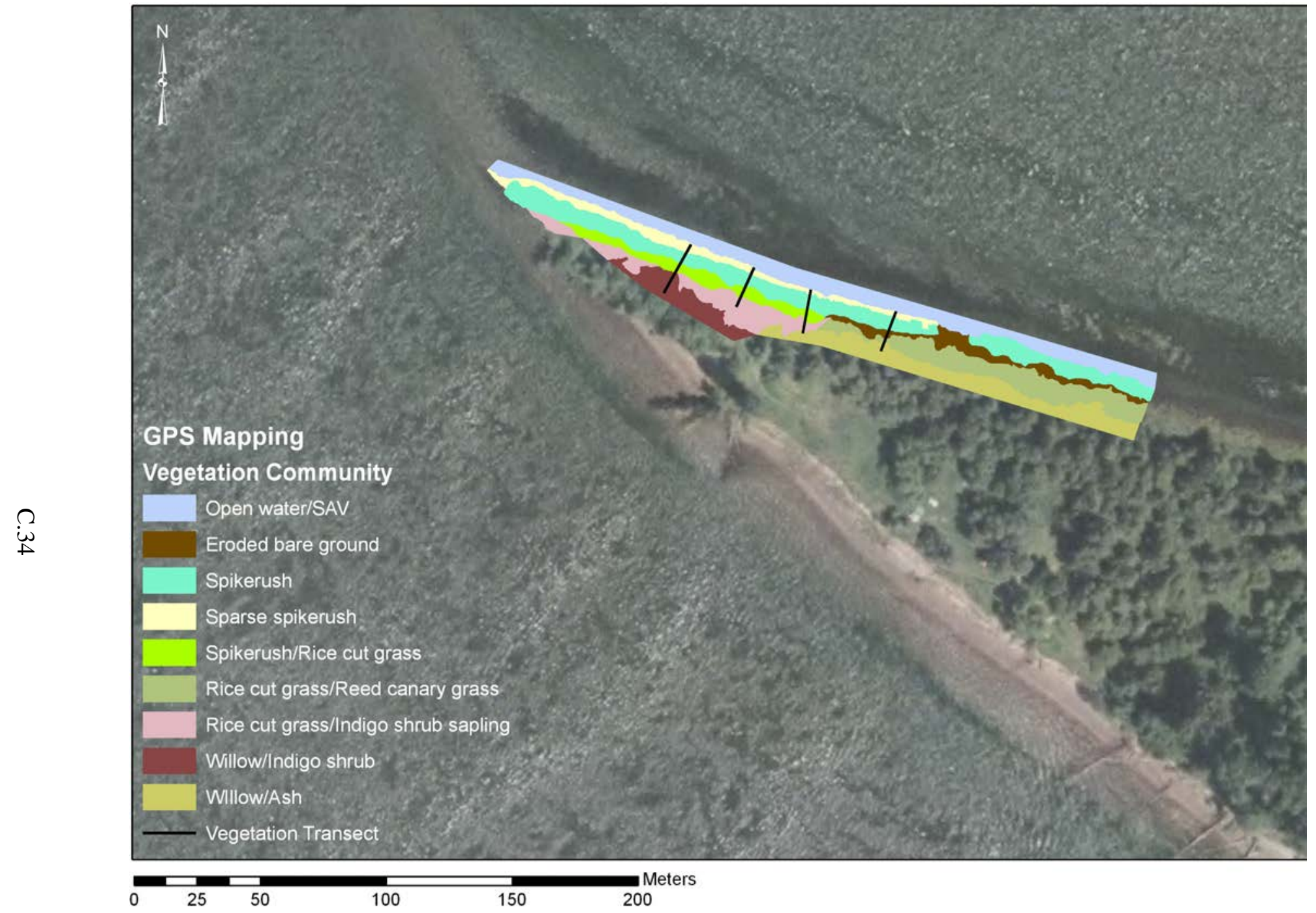

Figure A.34. Map showing the Reed Island Marsh site. 


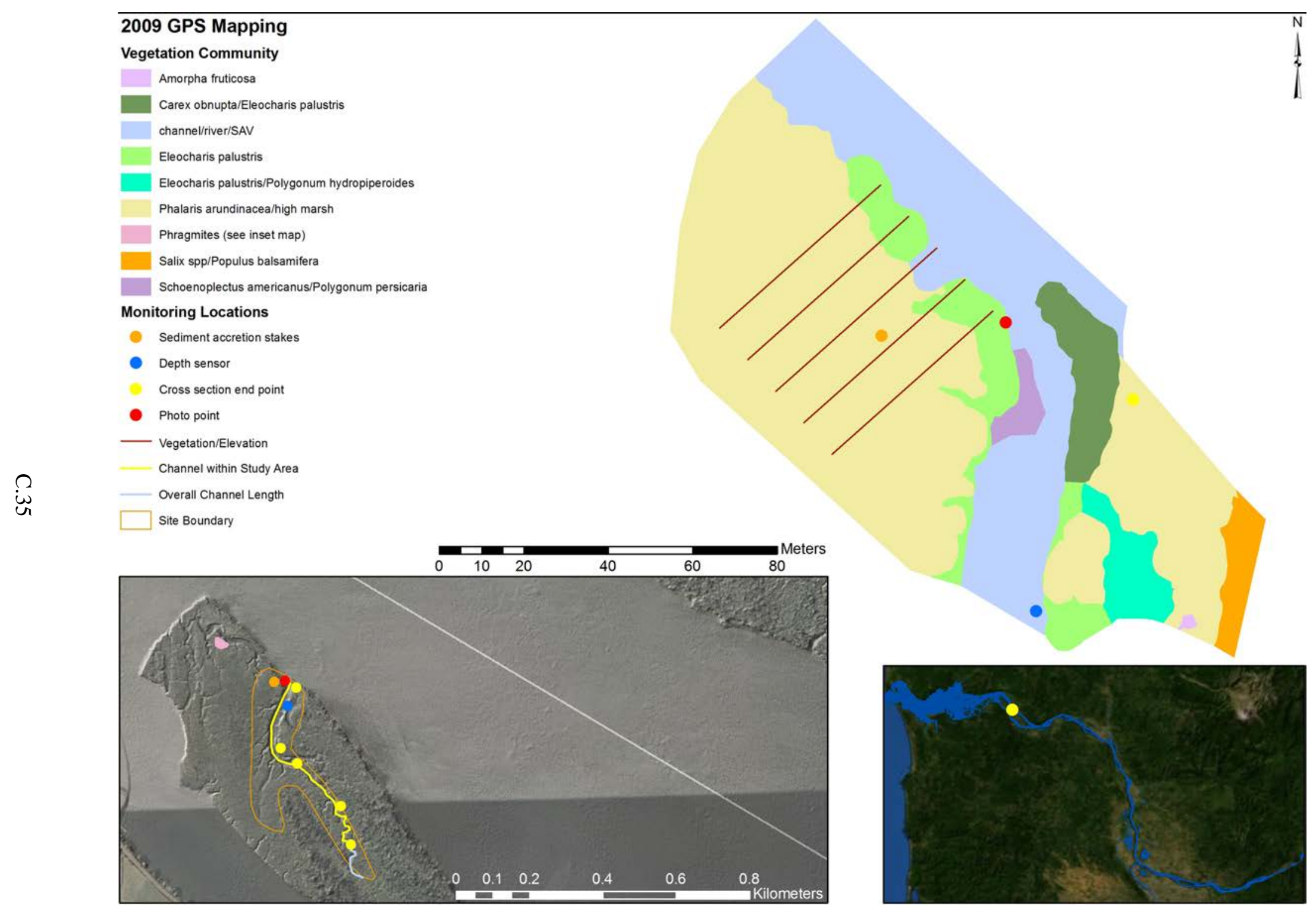

Figure A.35. Map showing the Ryan Island Marsh site. 


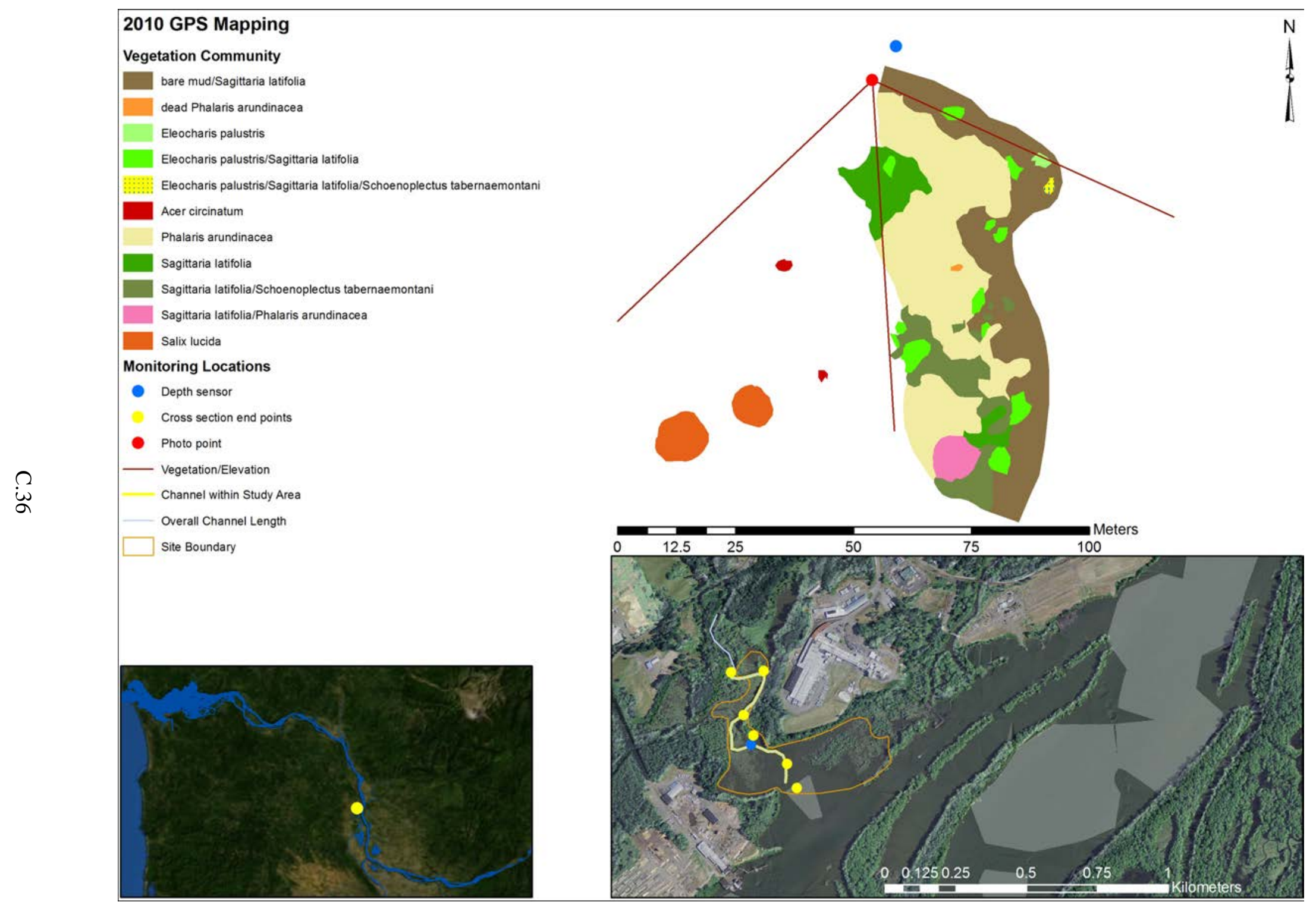

Figure A.36. Map showing the Scappoose Bay Marsh site. 


\section{GPS Mapping}

Vegetation Community

Eleocharis palustris

Monitoring Locations

Eleocharis palustris/Sagittaria latifolia

- Sediment accretion stakes

- Depth sensor

Eleocharis palustris/Sagittaria latifolia/Scirpus lacustris

E. palustris/S. latifolia/S. lacustris/Scirpus americanus

Eleocharis palustris/Scirpus hybrid

Cross section end stake

Open water/SAV

Photo point

Phalaris arundinacea

Iris pseudacorus

— Vegetation/Elevation Overall Channel Length

P. arundinacea/Cornus sericea/Populus balsamifera $\quad \square$ Site Boundary

Phalaris arundinacea/Salix spp,

P. arundinacea/S, latifolia/Polygonum hydropiperoides

Populus balsamifera

Sagittaria latifolia

Sagittaria latifolia/Polygonum hydropiperoides

Sagittaria latifolia/Potamogeton natans

Sagittaria latifolia/Scirpus americanus

Sagittaria latifolia/Scirpus lacustris

Scirpus lacustris
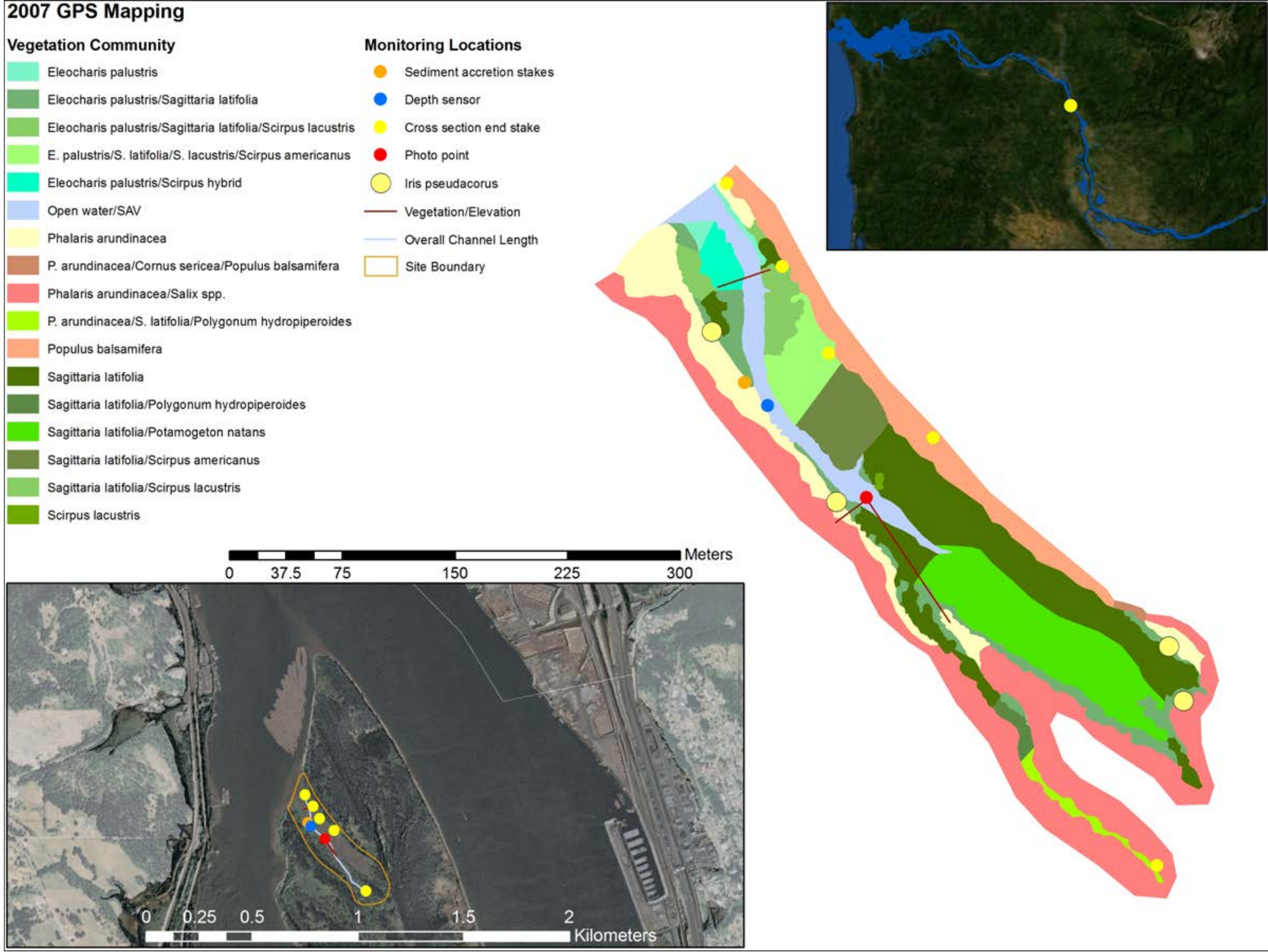

Figure A.37. Map showing the Sandy Island Slough Marsh site. 


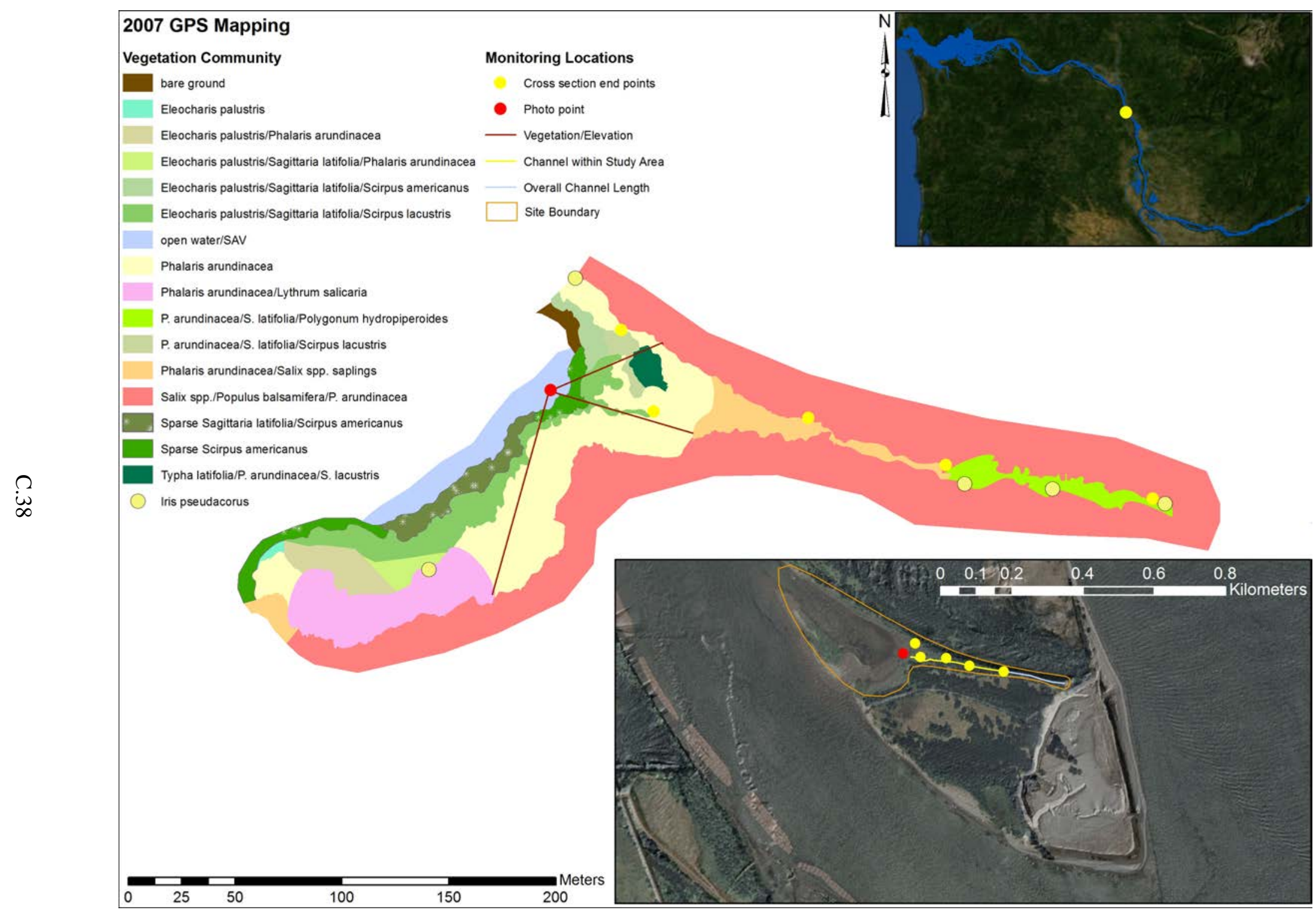

Figure A.38. Map showing the Sandy Island 2 Marsh site. 
2008 GPS Mapping

Vegetation Community

Cornus stolonifera/Salix spp./Fraxinus latifolia

Eleocharis palustris

Eleocharis palustris/Polygonum persicaria/Ludwigia palustris

Eleocharis palustris/Sagittaria latifolia

Eleocharis palustris/Scirpus lacustris

open water/Ludwigia palustris/Polygonum persicaria

open water/SAV

Phalaris arundinacea

Phalaris arundinacea/Carex spp.

Phalaris arundinacea/Eleocharis palustris

Phalaris arundinacea/Ludwigia palustris/Eleocharis palustris

Phalaris arundinacea/Salix spp.

Sagittaria latifolia

sand

Monitoring Locations

- Sediment accretion stak

- Depth sensor

Cross section end point

- Photo point

- Vegetation Transect

Channel within Study Area
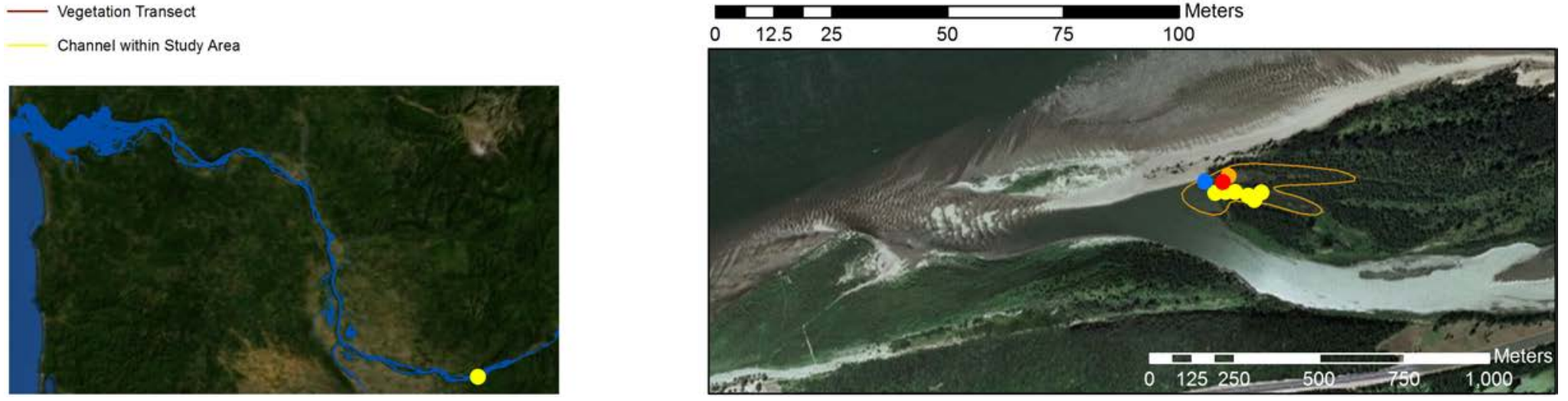

Figure A.39. Map showing the Sand Island (Rooster Rock) Marsh site. 


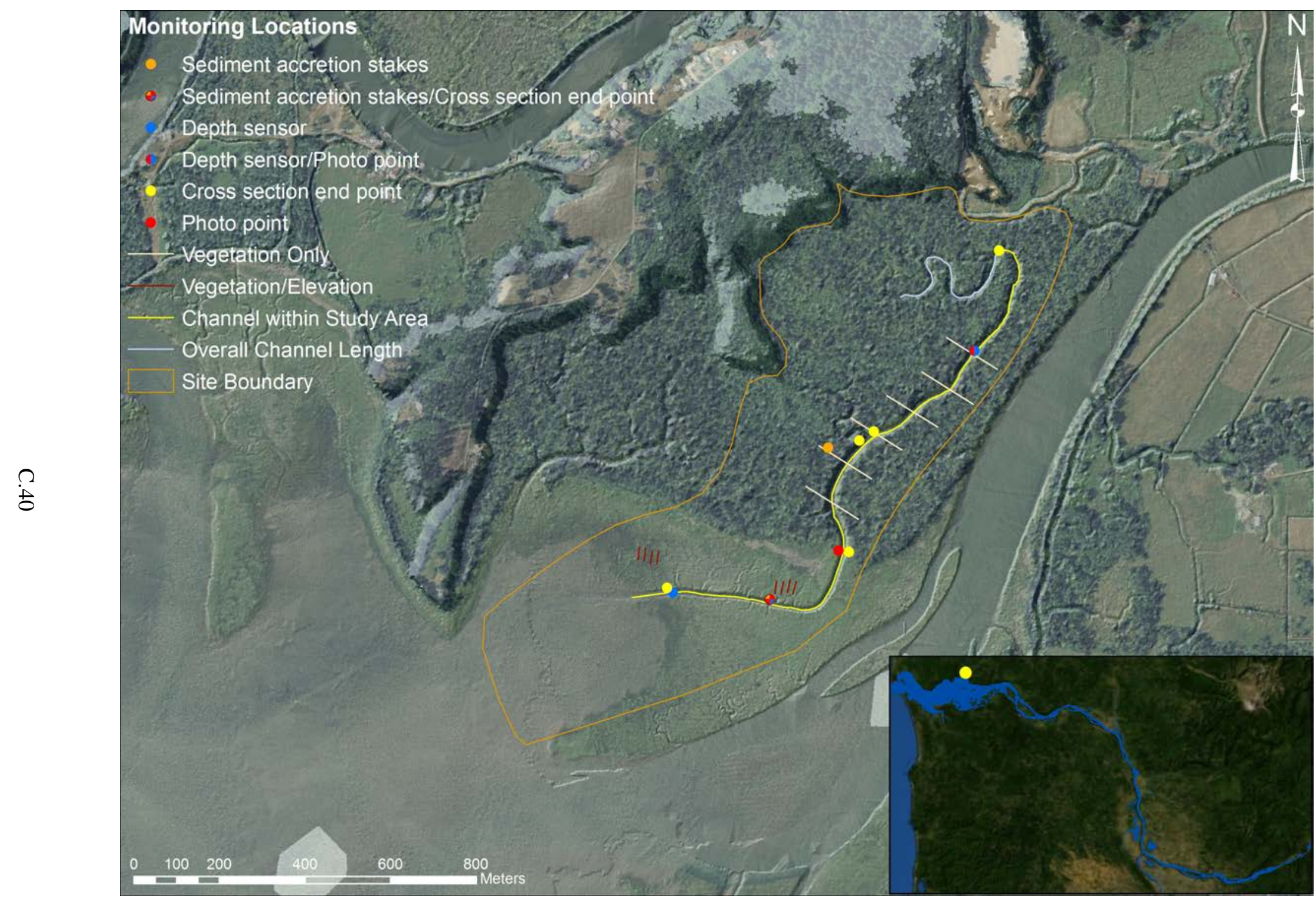

Figure A.40. Map showing the Secret River Marsh and Swamp sites. 


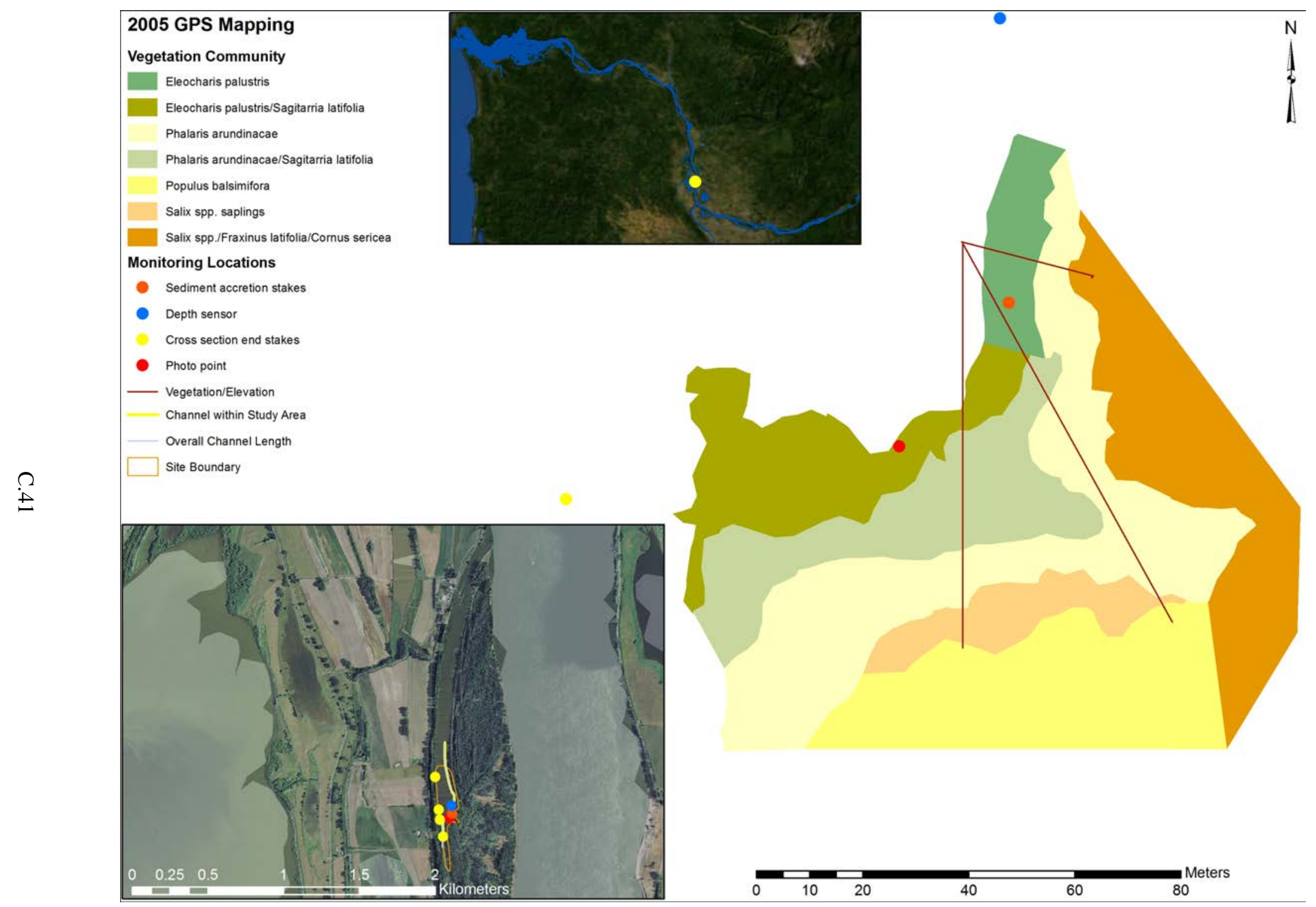

Figure A.41. Map showing the Sauvie Island East Slough Marsh site. 


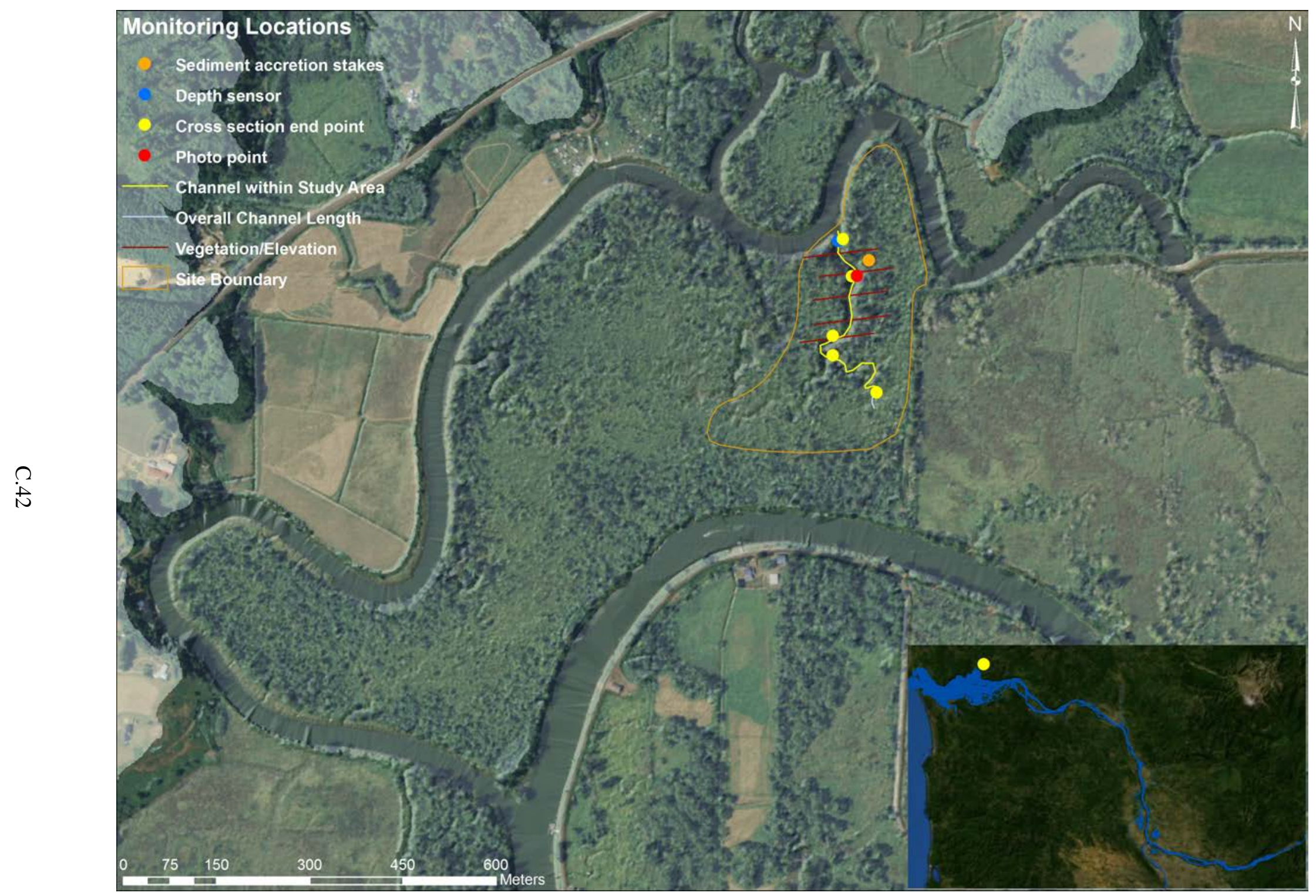

Figure A.42. Map showing the Seal Slough Swamp site. 


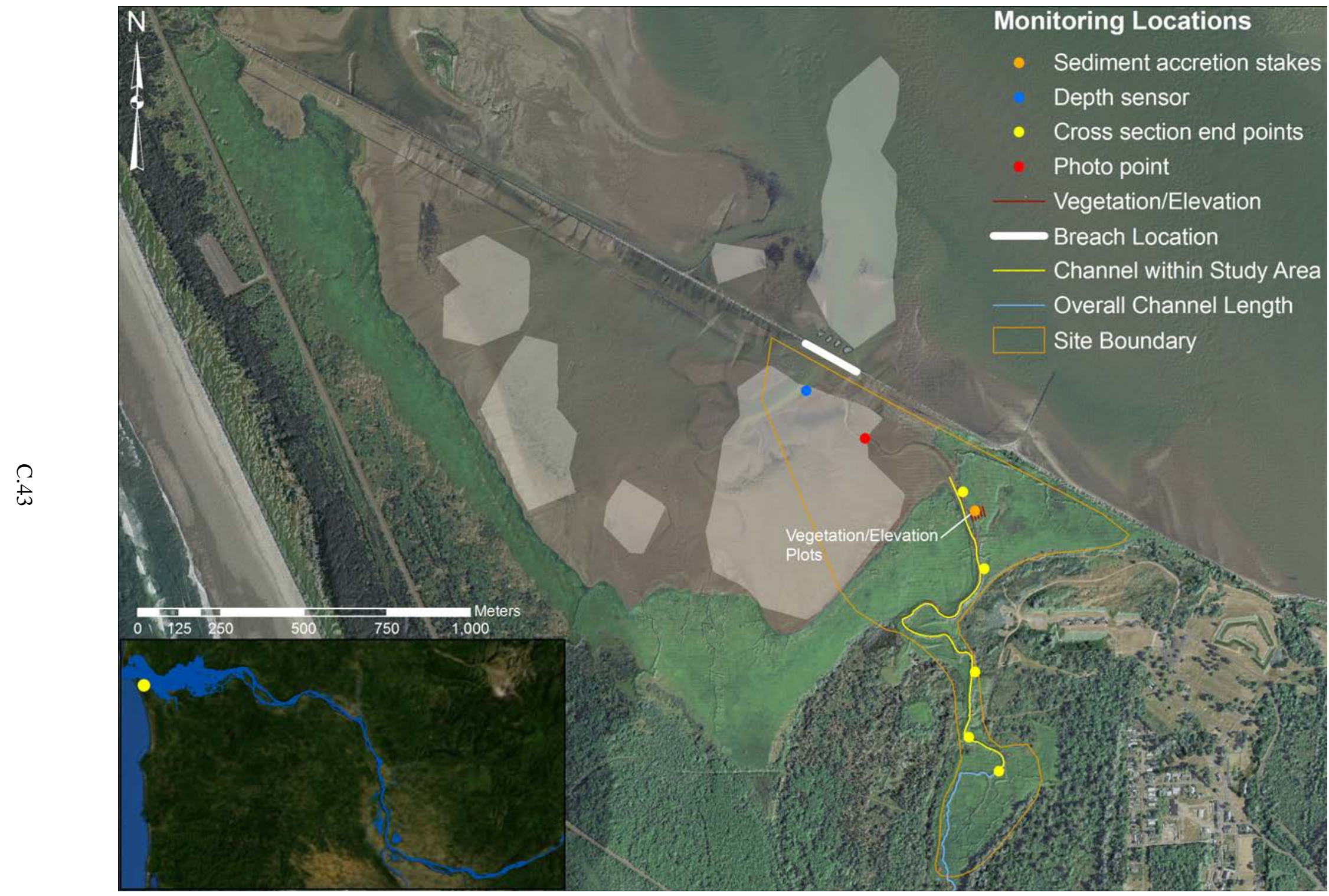

Figure A.43. Map showing the Trestle Bay Dike-breach Marsh site. 


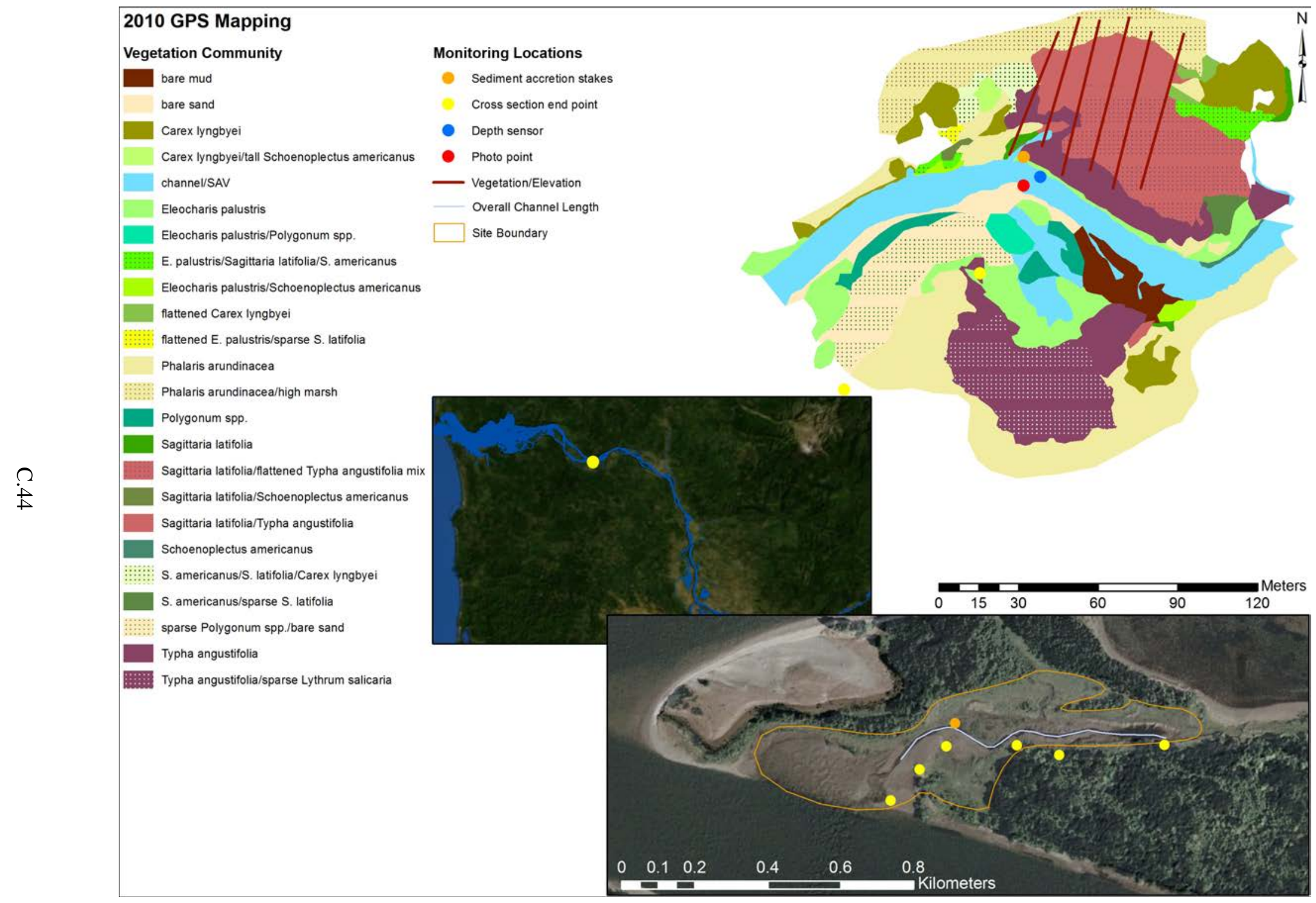

Figure A.44. Map showing the Wallace Island West Marsh site. 


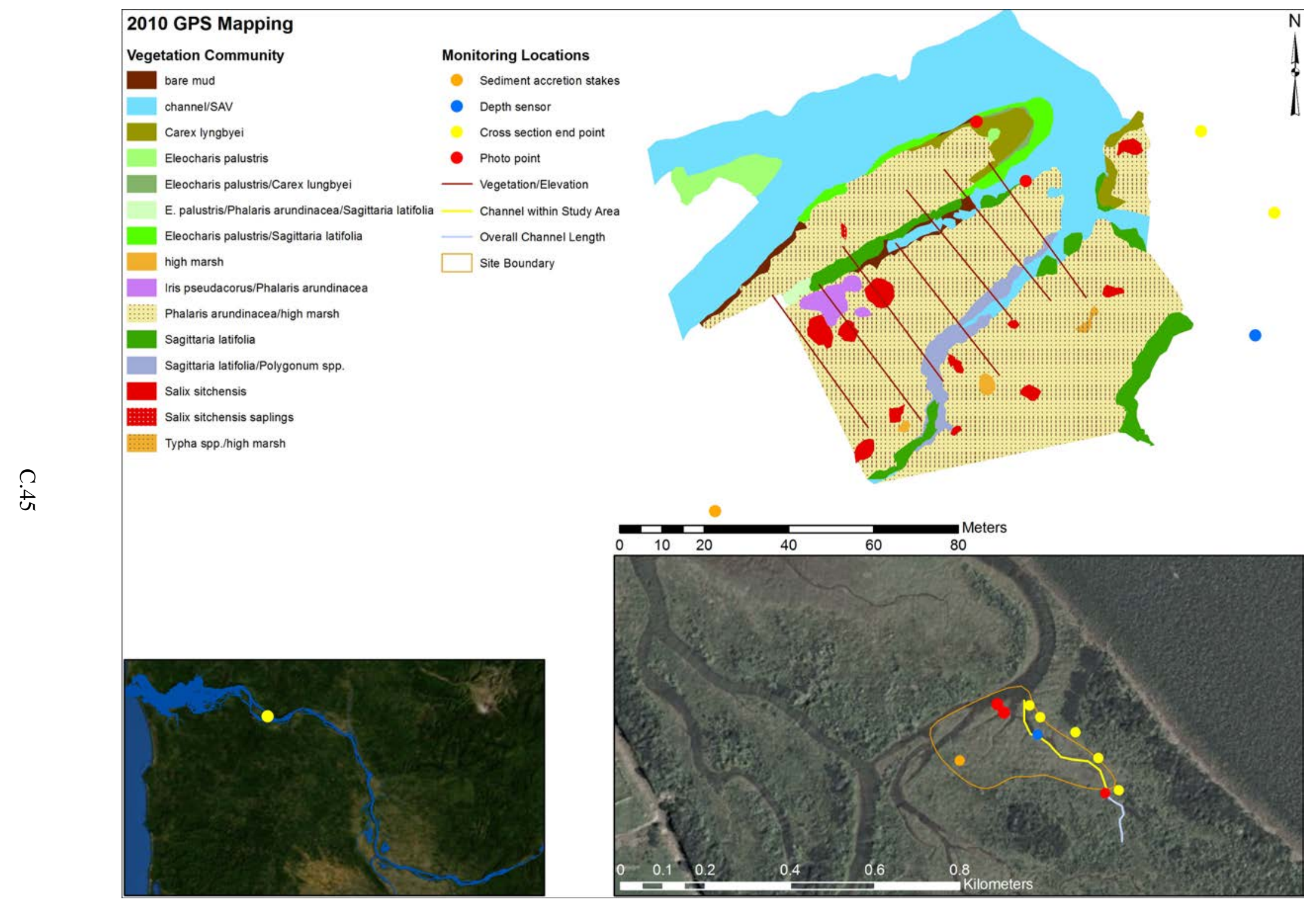

Figure A.45. Map showing the Whites Island Marsh site. 


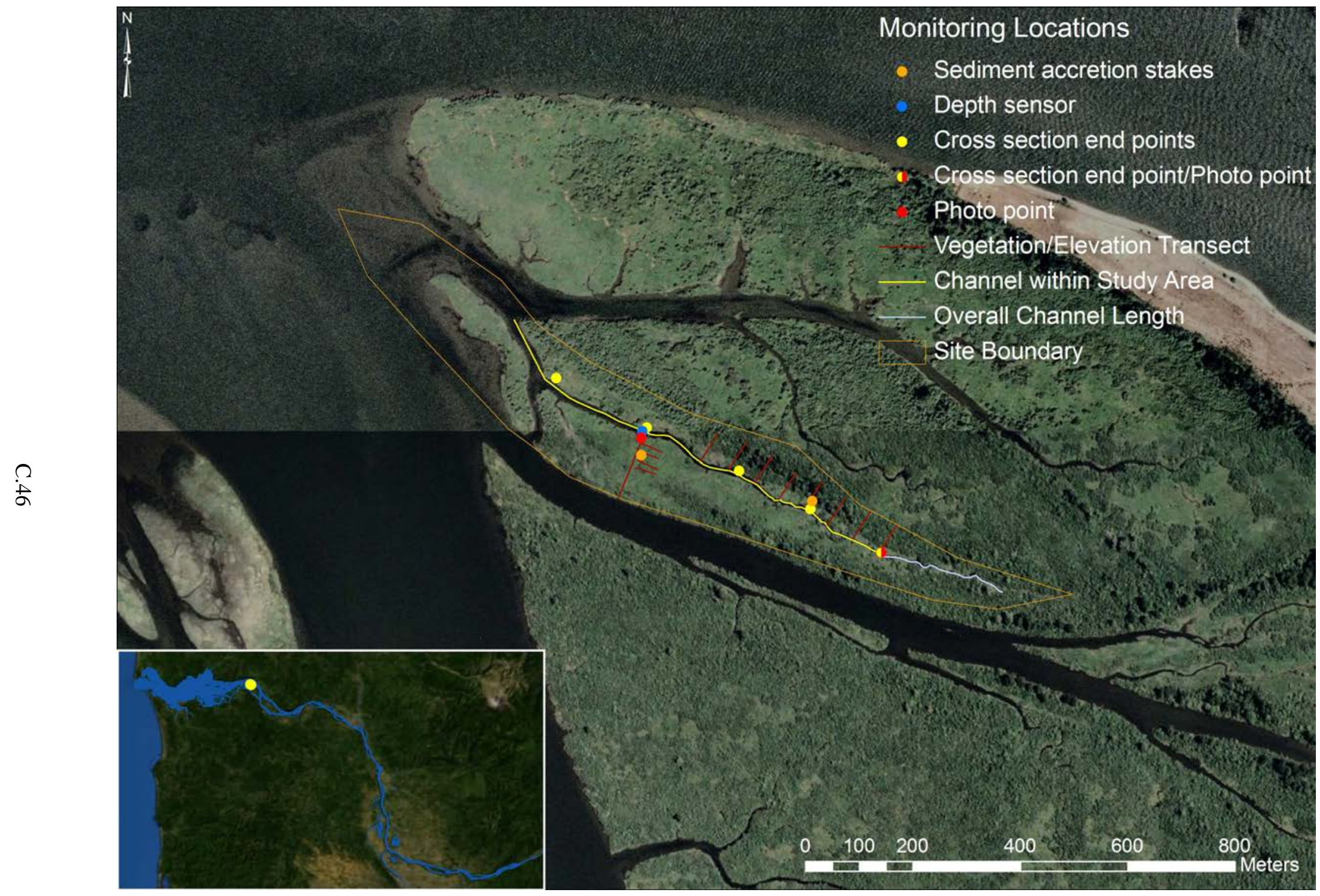

Figure A.46. Map showing the Welch Island Marsh and Shrub Wetland sites. 


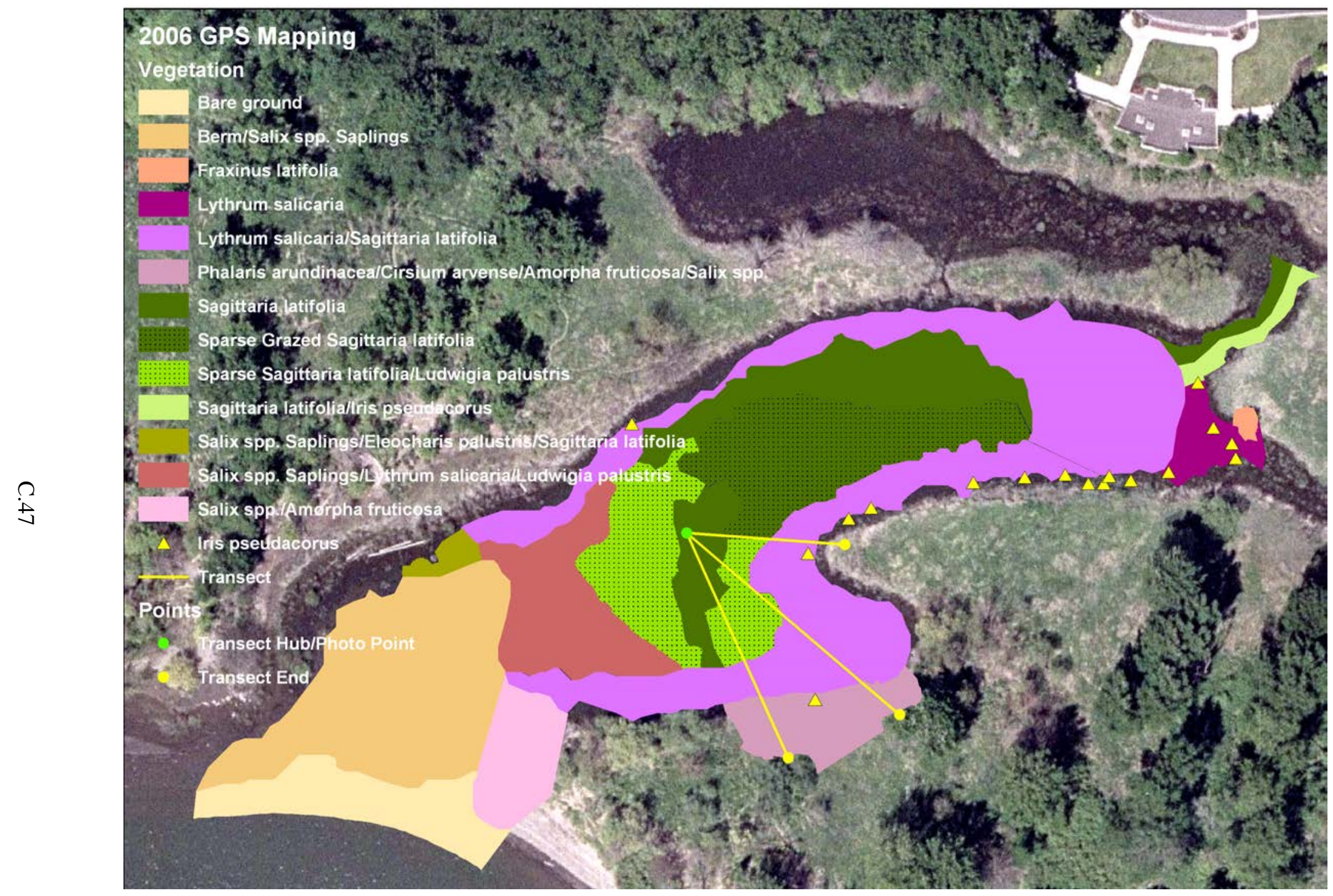

Figure A.47. Map showing the Water Resources Center Marsh site. 


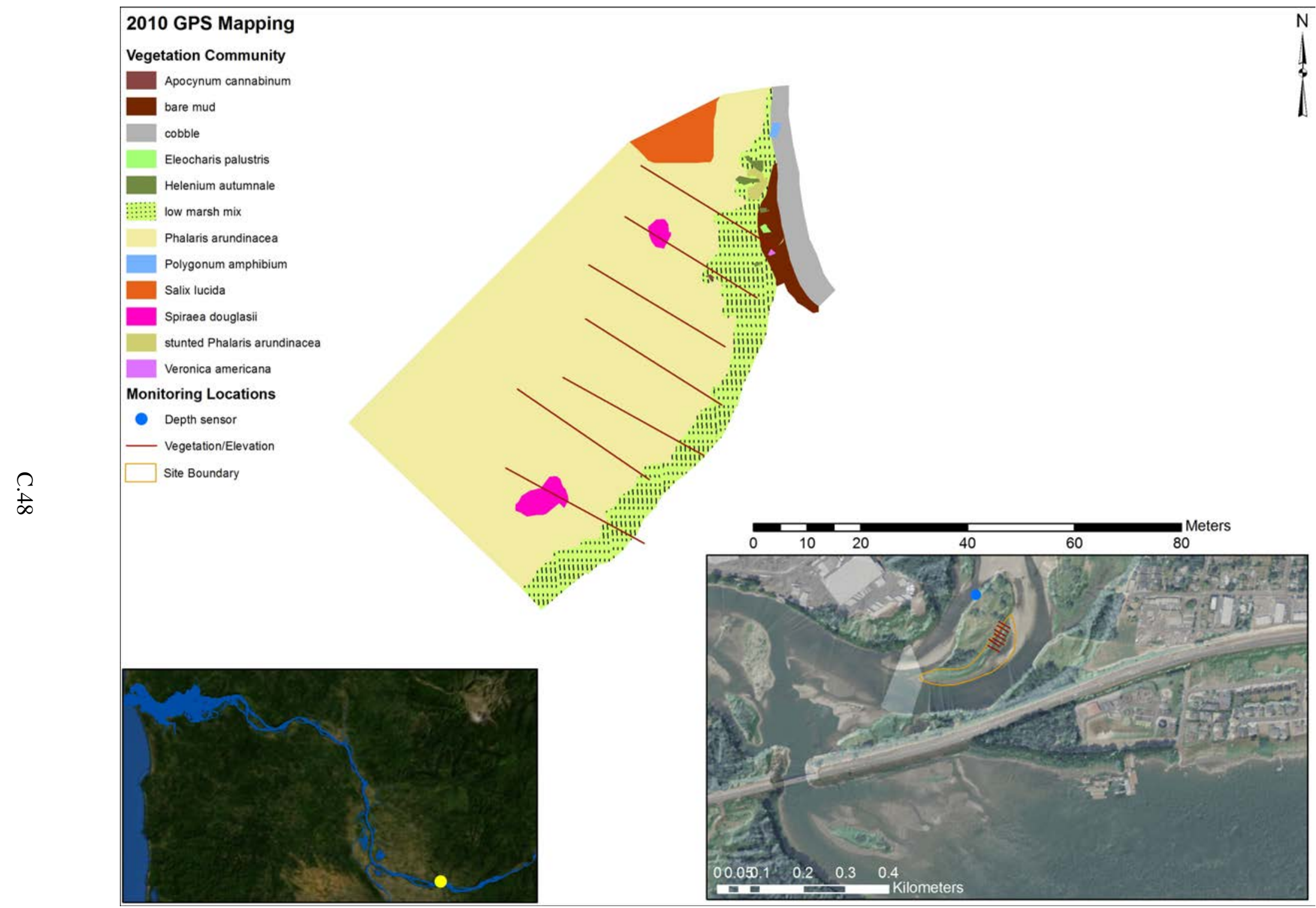

Figure A.48. Map showing the Washougal River Mouth Marsh site. 


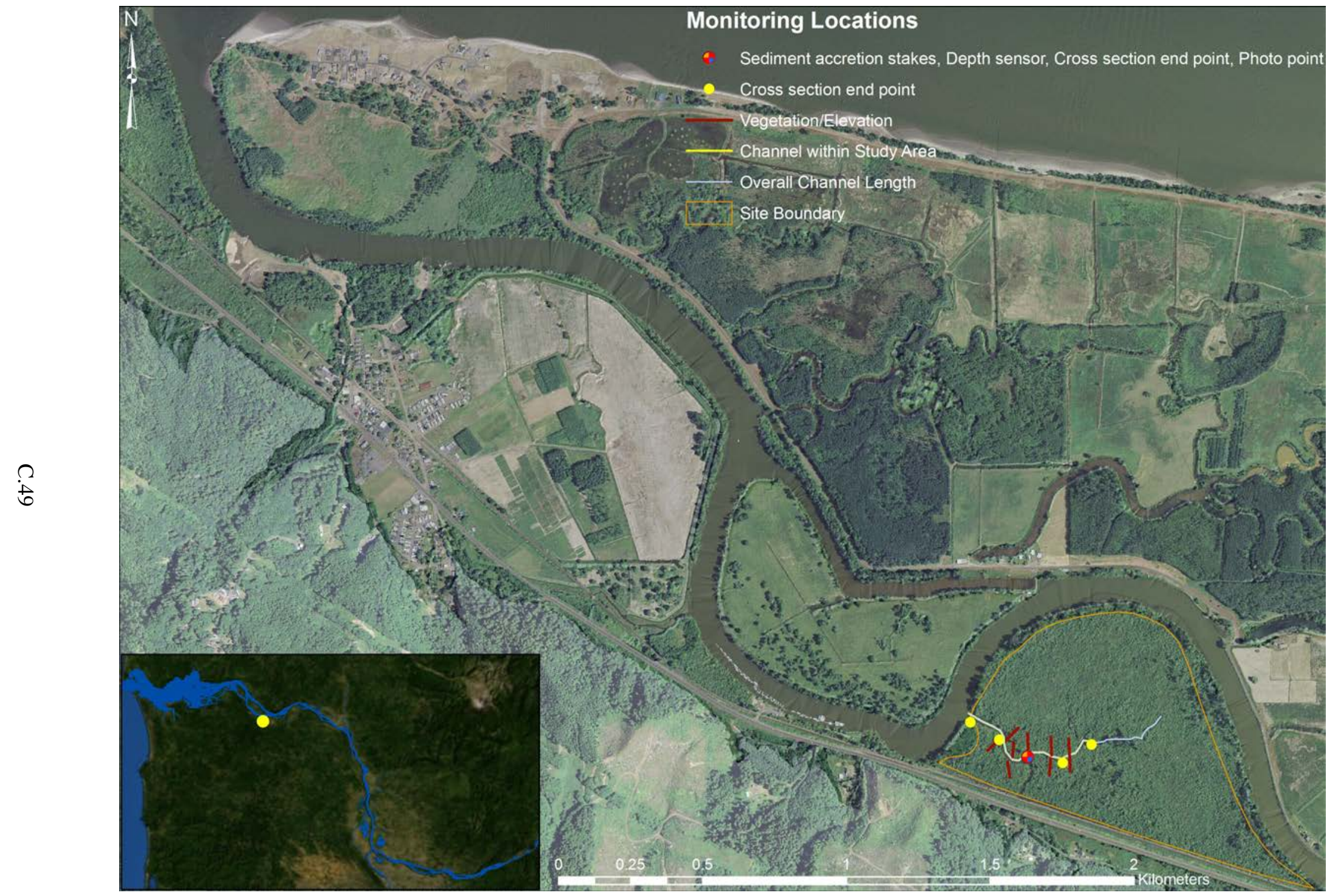

Figure A.49. Map showing the Westport Slough Shrub Wetland site. 



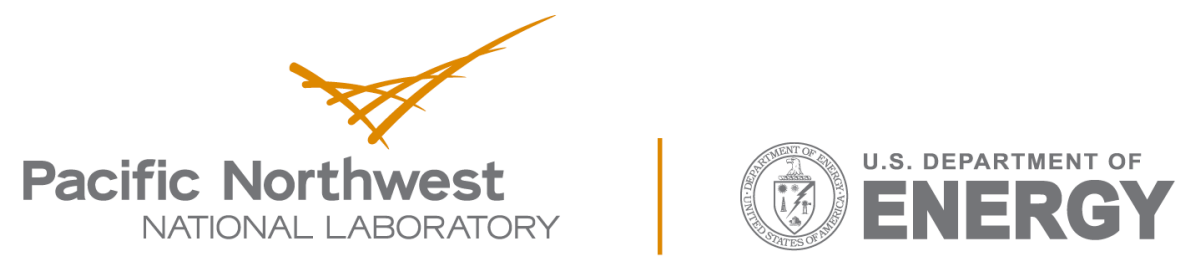

Proudly Operated by Battelle Since 1965

902 Battelle Boulevard

P.O. Box 999

Richland, WA 99352

1-888-375-PNNL (7665)

www.pnnl.gov 